If you do not need this publication after it has served your purpose, please retum it to the Geological Survey, using the official mailing label at the end

UNITED STATES DEPARTMENT OF THE INTERIOR

NONMETALLIC MINERAL RESOURCES OF EASTERN OREGON

Prepared in cooperation with the STATE MUNING BOARD OF OREGON

GEOLOGICAL SURVEY BULLETIN 875 
UNITED STATES DEPARTMENT OF THE INTERIOR

Harold L. Ickes, Secretary

GEOLOGICAL SURVEY

W. C. Mendenhall, Director

\section{Bulletin 875}

\section{NONMETALLIC MINERAL RESOURCES OF EASTERN OREGON}

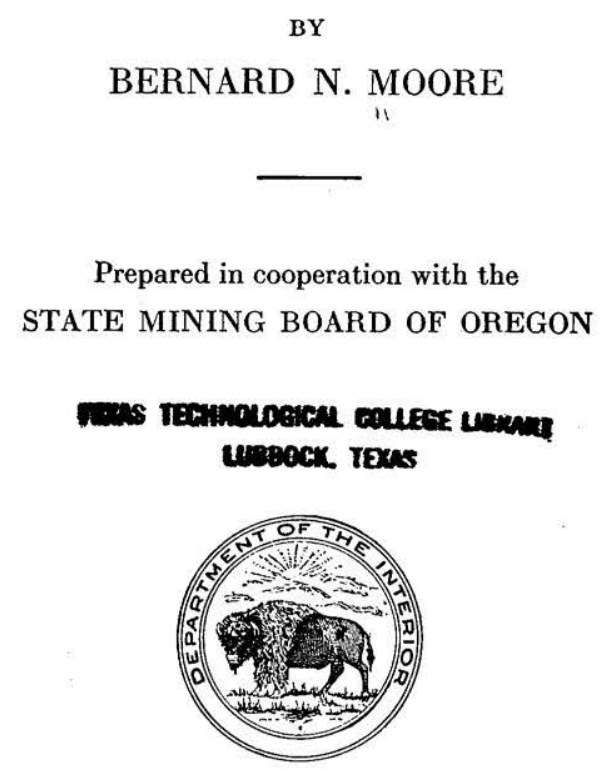

UNITED STATES

GOVERNMENT PRINTING OFFICE

WASHINGTON : 1937

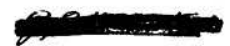

For sale by th: Superintendent of Documents, Washington, D. C. - - - - Price 30 cents 


\section{CONTENTS}

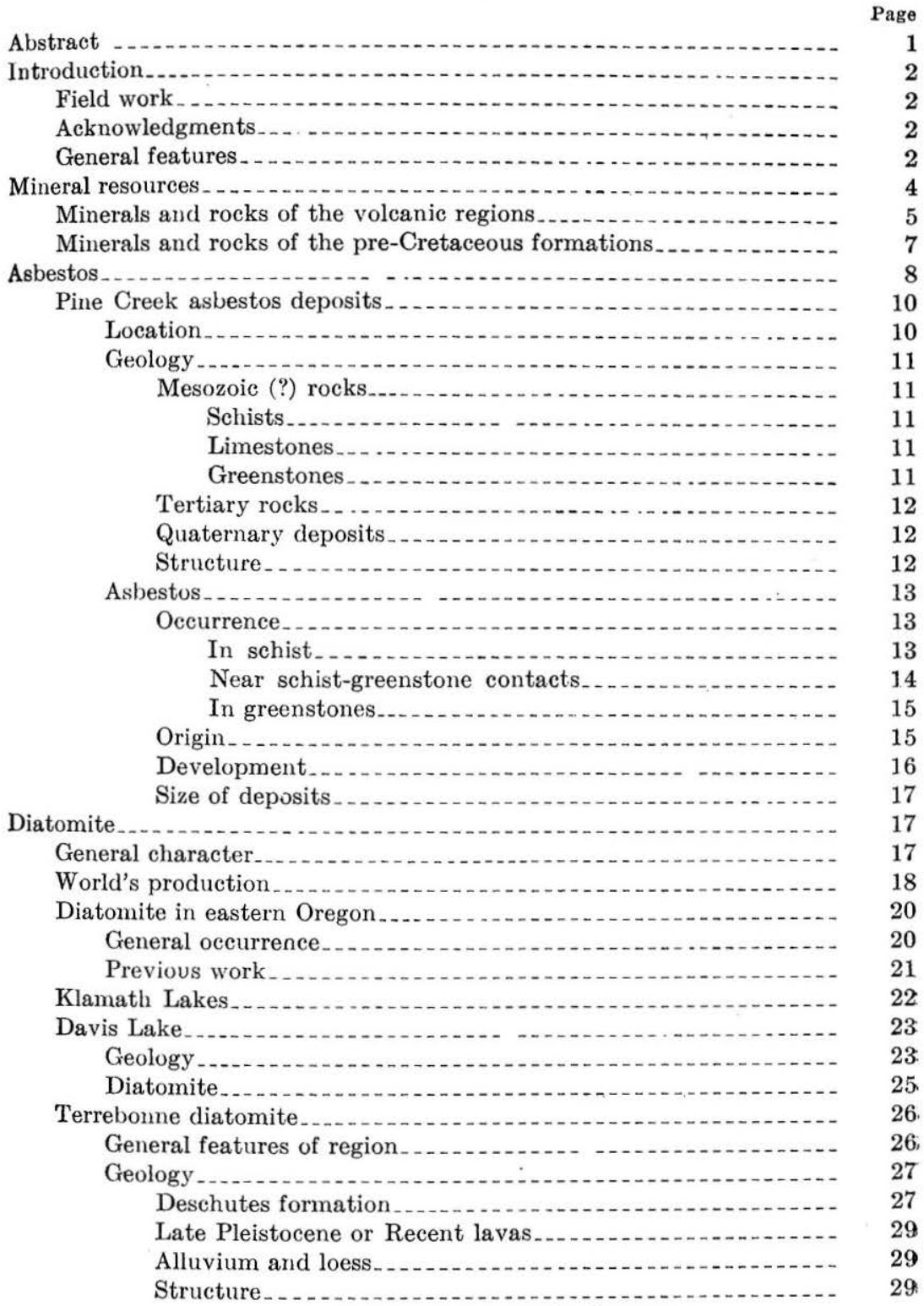


Diatomite-Continued.

Terrebonne diatomite-Continued.

Diatomite

Occurrence.

Conclusions . _.

Development. .

Diatomite near Burns...

Geology

Diatomite.......... 33

Klamath diatomite deposits . . .

Location...

Investigation

General features of district

Geography _.

Accessibility

Geology

Miocene(?) rocks..._.

Pliocene(?) rocks......... 37

Lower lavas . . . . . .

Diatomite............ 38

Upper lavas . .

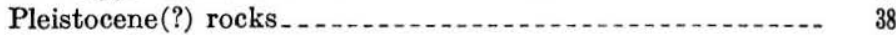

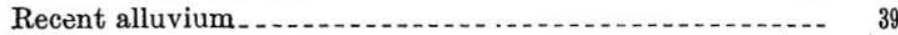

Structure.

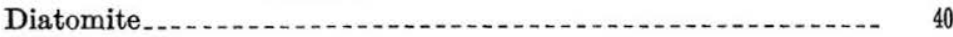

Chiloquin ...

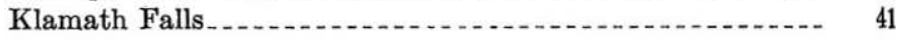

Poe Valley . . .

Sprague River district.

Alkali Valley

Olene district........... 49

Conclusions

Indian Creek diatomite.

Location _.

Geology

Diatomite

Clover Creek district. . . .

Location and field work

General features of district.......... 53

Geology .... . .

Stratigraphy

Structure

Diatomite

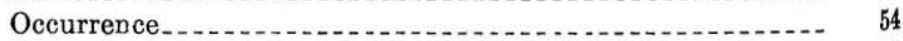

Quality _........ 54

Mining conditions

Development.

Richland diatomite..... 56

Location 56

Geology

Diatomite..... 57

Diatomite near Durkee

Swayze Creek

Manning Creek 
Diatomite-Continued.

Austin diatomite . 59

Location and general features..... 59

Geology _... 59

Diatomite........ 60

Tipton

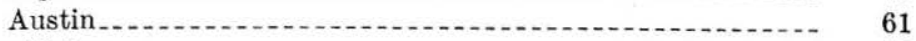

John Day Valley 63

Brogan . 64

Harper district... 65

Location

Investigations . . 65

Geography 65

Accessibility 66

Geology 66

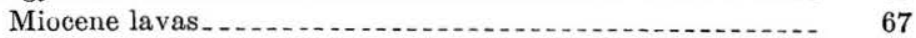

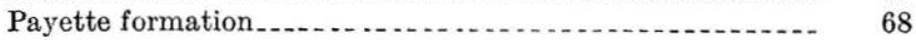

Lower agglomerate and tuff member..... 68

Lower diatomite member............. 69

Gray ash member. 70

Upper diatomite member................... 70

Rhyolite porphyry member.................... 71

Yellow tuff member......................... 71

Post-Payette rocks _... 71

Capping basalts.................. 71

Vitrophyres_... 72

Terrace gravel_........ 72

Recent alluvium 73

Structure _. 73

Slumping 73

Folds and faults _... 75

Geologic history 76

Diatomite....... 77

Distribution

Quality _... 87

Color and weight. 87

Toughness or strength 88

Chemical analyses.... 88

Microscopic analyses....... 88

Utilization _........... 92

Development_... 92

History

Development. 93

Products........ 95

Reserves........ 95

Otis Basin diatomite._._. 95

Location._. 95

Investigations

Topography 96

Accessibility 
Diátomite-Continued.

Otis Basin diatomite-Continued. Page

Geology

Tertiary deposits

Miocene lava......... 97

Payette formation .......... 98

Lower agglomerate member

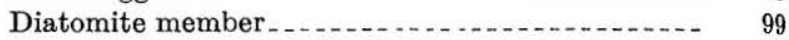

Upper agglomerate and tuff member.......... 99

Rhyolite porphyry member................. 99

Pliocene olivine basalt._.

Quaternary deposits_...

Structure $\ldots \ldots$

Folds_...

Faults . . . .

Intrusions ...

Diatomite............... 102

Occurrence

Quality

Toughness. . . . 104

Chemical composition........ 104

Microscopic examination........ 104

Possible utilization ............ 105

Size of deposit...... 105

Development_...................... 106

Quality of eastern Oregon diatomite_._. 107

Color.............. 107

Texture

Fracture, lamination, and toughness ... . . 112

Apparent density ............ 113

Chemical composition _.

Mịcroscopic examinations _...

Conclusions _. . .

Limestone................ 118

Occurrence _..._. 118

Wallowa County

Limestone on Imnaha River.......... 119

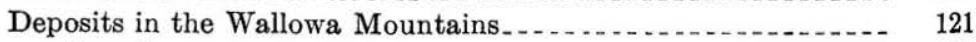

Location

Nature of investigations _.

Geography

Accessibility .....

Geology

Triassic sediments

Igneous rocks ........... 123

Basic dike rocks (Jurassic?) $\ldots$

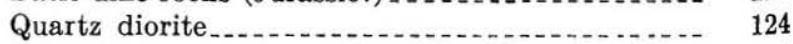

Columbia River lava....... 124

Structure

Geomorphic development. 127

Limestone....... 128

Lostine River. 129

Black Marble \& Lime Co

Hurricane Creek.... 132 
Limestone-Continued.

Page

Baker County _. 133

Eagle Creek .......... 133

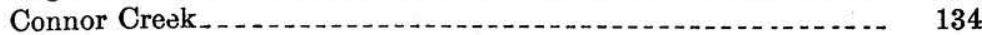

General features of district.

Geology

Triassic rocks

Igneous rocks........ 137

Dike rocks_.......... 137

Quartz diorite......... 137

Columbia River lava_.......... 138

Structure . .

Limestone.............. 139

Occurrence

Development_............. 139

Conclusions _.

Sisley Creek

Nelson........... 141

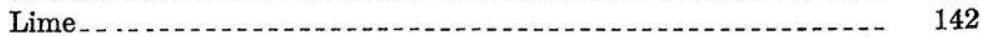

Geology

Triassic limestone ................................ 142

Volcanic rocks........... 143

Tertiary rocks . .

Quaternary deposits........ 143

Structure $\ldots$

Limestone....... 144

Mining companies......... 144

Crook and Grant Counties.

Wheeler County

Shoofly Creek

Lump pumice... 149

Production

Bend-Klamath Falls region

Location

Investigation . .

Topography

Drainage.... 152

Geology

Pre-pumice rocks

Occurrence...... 153

Age

Pumice

Pumice of Crater Lake... 156

Older pumice.

Younger pumice............. 158

Relations of the pumice sheets

Origin

Pumice of Newberry Crater . .

Pumice of Devils Hill .

Post-pumice rocks

Economic aspects of the pumice

Development.

Index 


\section{ILLUSTRATIONS}

Plate 1. Index map of central and eastern Oregon showing location of deposits described in report . ...

2. Geologic sketch map of Pine Creek asbestos deposits, Baker

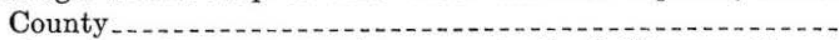

3. A, Long slip-fiber asbestos in prospect pit; $B$, View northwest across quarry of Atomite Corporation near Terrebonne, Deschutes County -

4. Photomicrographs of strewn mounts of uncleaned diatomite of eastern Oregon.

5. Geologic sketch map of the Klamath diatomite district, Klamath County..

6. Photomicrographs of strewn mounts of uncleaned diatomite of

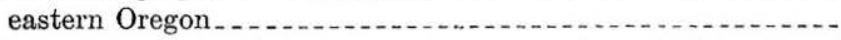

7. Photomicrographs of strewn mounts of uncleaned diatomite of

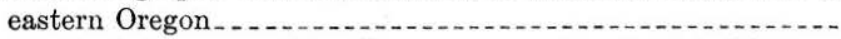

8. Geologic sketch map of the Harper diatomite district, Malheur County ............ In pocket

9. $A$, Distorted diatomite in banks of Vale irrigation canal; $B$, View in no. 10 quarry of Pacific Coast Diatom Corporation,

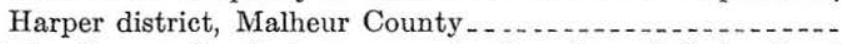

10. Photomicrographs of strewn mounts of uncleaned diatomite of

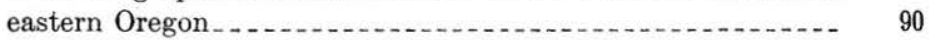

11. Geologic sketch map of Otis Basin, Harney County ......... In pocket

12. $A$, Hill of diatomite in $\mathrm{SE} 1 / 4 \mathrm{SE}^{1 / 4}$ sec. 14, T. $20 \mathrm{~S}$., R. 36 E., Otis Basin, Harney County; $B$, Granular pumice in cut on Southern Pacific Railroad about 2 miles north of Chemult........

13. Geologic reconnaissance sketch map of a part of the Wallowa Mountains, Wallowa County .................................

14. Geologic map of limestone deposit of Connor Creek district, Baker County

15. Geologic map of limestone deposit at Lime, Baker County ...-

16. Sketch map showing distribution of pumice deposits in Klamath and Deschutes Counties.......................... pocket

Frgure 1. Index map showing location of Pine Creek asbestos deposits_- 10

2. Cross-fiber anthophyllite veins in crushed zone in schist..... 14

3. Sketch map showing location of Davis Lake _............. 25

4. Map of diatomite deposits at Lower Bridge, near Terrebonne,

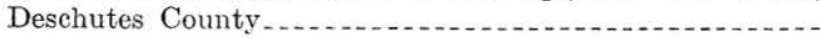

5. Sketch illustrating difference between a slumped block and a faulted blosk having similar outcrops .....................

6. Columnar sections of the diatomite deposits of the Harper district.

7. Map showing location of diatomite claims near Harper, Malheur County.

8. Size distribution of finer parts of older pumice of Crater Lake_.

9. Size distribution of younger pumice of Crater Lake.......-

10. Sketch of Newberry Crater showing approximate location of cones and distribution of pumice.....

11. Size distribution of pumice from Newberry Crater....... 


\title{
NONMETALLIC MINERAL RESOURCES OF EASTERN OREGON
}

\author{
By Bernard N. Moore
}

\begin{abstract}
In the summer of 1930 the United States Geological Surrey began an investigation of the nonmetallic mineral resources of eastern Oregon in cooperation with the Oregon State Mining Board. This work was continued in 1931, and the results are incorporated in the present report.

Much of the work was necessarily reconnaissance to indicate the general nature and distribution of the various geologic formations. More intensive study was made of the nonmetallic mineral deposits. Besides building stone and road material, which are abundant and widely distributed, the nonmetallic resources that offer hope of commercial production are asbestos, bentonitic clays, diatomite, limestone, pumice, and salines. Prospecting of the clays and salines is warranted in the more accessible locations. Deposits of chrysotile asbestos may occur in the areas of serpentine rocks, but no sizable bodies of gypsum are known. High-silica sand does not occur in this region, and it is believed that prospecting for glass sand would be useless.

The amphibole asbestos deposit on Pine Creek, Baker County, is described. No estimate of the tonnage of this deposit is yet possible.

Fourteen deposits of diatomite are described, ranging in age from probably middle Miocene to Recent. These include the extensive deposit on the Deschutes River near Terrebonne and large deposits of excellent diatomite near Harper, Malheur County, and Drewsey, Harney County. These deposits are easily accessible and offer very large tonnages of the earth. Much of the Oregon diatomite appears to be suitable for most purposes for which this material is used.

Limestone in commercial quantity is restricted to the pre-Cretaceous crystalline rocks of the northeastern part of the region. Notwithstanding the relative scarcity of limestone in Oregon, the distance of these deposits from centers of consumption on the coast has hindered their development. Eleven deposits are described. Those of the Wallowa Mountains are very large, and those on Connor Creek are not only large but exceptionally pure.

Lump pumice occurs in Deschutes and Klamath Counties as a blanket corering about 3,500 square miles of surface. Two of the pumice sheets making up this blanket had their origin in the crater of Mount Mazama, the ancient volcano whose collapse formed the depression containing Crater Lake. The older of these sheets consists of an unsorted mixture ranging from fine dust to lumps of pumice more than 3 feet in diameter. The younger sheet consists of well-sorted granular pumice. The pumice in both sheets is coarsely vesicular and porphyritic. Its uses are probably restricted, though many deposits occur along the main lines of the Great Northern Railway and Southern Pacific Railroad. A deposit of high-grade pumice lies east of the Paulina Lakes in Deschutes County. It had its origin in the crater of old Mount Newberry and is very finely vesicular and nonporphyritic. Although it is about 15 miles from the railroad, its high quality may afford it some chance of development.
\end{abstract}




\section{INTRODUCTION}

\section{FIELD WORK}

In the summer of 1930 the United States Geological Survey began a study of the nonmetallic mineral resources of eastern Oregon in cooperation with the Oregon State Mining Board. Because little published information was available about the mineral resources or geology of this region, the first season's field work was largely a reconnaissance. R. W. Richards, assisted by me, spent nearly 4 months in the field studying and mapping the geology and examining all developed deposits, together with such undeveloped deposits as appeared of possible interest. In $1931 \mathrm{I}$ spent 4 months in more detailed study of deposits noted as interesting in the previous field season. Among these were the pumice deposits of the Bend-Klamath Falls region, the limestones of the Wallowa and Connor Creek districts, an asbestos deposit on Pine Creek, and the diatomite deposits at Harper and in the Otis Basin. Further detailed work is obviously needed on some of the deposits here described, but it is hoped that this report will serve to acquaint those interested in the nonmetallic mineral resources of eastern Oregon with the more outstanding possibilities.

\section{ACKNOWLEDGMENTS}

During this work many persons have given assistance and information with an unusually friendly and cooperative spirit. I wish to mention Messrs. Frank McColloch and W. H. Strayer, of Baker, in particular. Dr. E. W. Lazell, of Portland, furnished much information concerning various mineral resources. Acknowledgment of other assistance is given in the discussion of individual districts.

I have received many ideas from $\mathrm{Mr}$. R. W. Richards, with whom I was associated during the first field season and who had begun reports on that work before being assigned to other projects. Mr. J. P. Buwalda introduced me to the stratigraphy of eastern Oregon. The many valuable ideas which have grown out of discussions thus originated are difficult of direct acknowledgment. To Mr. James Gilluly, who has worked on the geology of the Baker quadrangle, and Messrs. J. T. Pardee and D. F. Hewett, who have worked on the geology of the Sumpter quadrangle, I am also indebted for many ideas that it would be difficult to acknowledge specifically.

\section{GENERAL FEATURES}

As shown on plate 1, eastern Oregon, as generally spoken of, comprises two-thirds of the entire State, including all that part east of the crest of the Cascade Range. It is usually considered a high arid country, though there is considerable variation of temperature and 
precipitation according to altitude and distance from the Cascade Range.

Eastern Oregon lies mainly in the Columbia Plateau province, though its southern part reaches into the Great Basin. Topographically the part located in the Columbia Plateau province consists of a broad plateau in the northwestern part, which slopes up from the Columbia River to the Ochoco Mountains; the Ochoco and Blue Mountains, which extend nearly across the State and curve in their northward extension across the Washington border; the Wallowa Mountains and ranges of Baker County, in the northeastern part, which form a sort of basin and range topography distinct from the Blue Mountains; and a central plateau area south of the Ochoco Mountains, dissected to the east and west by the Malheur and Deschutes Rivers and known in its central part as the Harney Basin. South of this plateau and merging with it is a belt of block ranges and basins extending across the entire width of eastern Oregon and forming the northern part of the Great Basin.

The rocks of eastern Oregon are composed of two main groups, the Tertiary formations and the Cretaceous and pre-Cretaceous formations (commonly called basement complex). The best-known section is that of the John Day region, in the Ochoco Mountains.

Formations of the John Day region

\begin{tabular}{|c|c|c|c|}
\hline & Age & Formation & Character \\
\hline \multirow{2}{*}{ 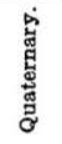 } & Recent. & & \\
\hline & Pleistocene. & \multirow{6}{*}{$\begin{array}{l}\text { Rattlesnake formation. } \\
\text {-Unconformity - } \\
\text { Mascall formation. } \\
\text {-Disconformity (?) } \\
\text { Columbia River lava. } \\
\text {-Unconformity - } \\
\text { John Day formation. } \\
\text {-Unconformity - Clarno formation. } \\
\text {-Uneonformity - }\end{array}$} & \\
\hline \multirow{5}{*}{ 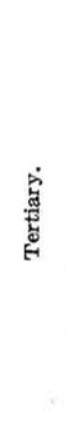 } & Pliocene. & & $\begin{array}{l}\text { Tuffaceous sand and gravel, with pumiceous thyolite } \\
\text { flow. }\end{array}$ \\
\hline & \multirow{2}{*}{ Miocene. } & & Tuff and clay. \\
\hline & & & Basalt and andesite. \\
\hline & Oligocene. & & $\begin{array}{l}\text { Brilliantly colored tuffs with interbedded stream } \\
\text { deposits and lava. }\end{array}$ \\
\hline & Eocene. & & $\begin{array}{l}\text { Chaotic series of siliceous tufis and eruptive roeks } \\
\text { resting on a basal series of basaltic lavas. }\end{array}$ \\
\hline 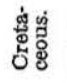 & $\begin{array}{l}\text { Upper Cre- } \\
\text { taceous. }\end{array}$ & & $\begin{array}{l}\text { Deposits corresponding to Chice formation of Cali- } \\
\text { fornia. }\end{array}$ \\
\hline 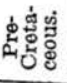 & & & Quartzite, chert, and marble. \\
\hline
\end{tabular}


Of these formations the most extensive areally is the Columbia River lava, which underlies the entire plateau between the Columbia River and the Ochoco and Blue Mountains. In these mountains streams have removed much of this formation, exposing the underlying John Day and Clarno and, in the cores of anticlines, even the Cretaceous and pre-Cretaceous rocks. In the Blue Mountains the Columbia River lava rests on the pre-Cretaceous rocks, large areas of which are exposed. In most places they are metamorphosed, but in the region south of Canyon City an excellent section of fossiliferous Carboniferous, Triassic, Jurassic, and Cretaceous sediments is exposed. In Baker and Union Counties east of the Blue Mountains there are extensive exposures of the pre-Cretaceous rocks, covered in places by the Columbia River lava and later Tertiary formations.

Associated with the Columbia River lava in different parts of the region are the Dalles formation (Miocene or Pliocene), the Mascall formation (Miocene), unnamed deposits of the Blue Mountains and Baker regions, and the Payette formation (Miocene). North of the central part of the State the sedimentary formations have been largely eroded away, but to the south they are covered with a thick series of late Tertiary and Quaternary lavas. The plateau on which the Harney Lakes lie and the block ranges in the extreme southern part of the region are formed of these late volcanic rocks.

\section{MINERAL RESOURCES}

In this report only nonmetallic minerals other than fuels have been considered. Collier ${ }^{1}$ has described the coals of the John Day country, and Mendenhall ${ }^{2}$ those of Morrow County. The gas and oil prospects of eastern Oregon have been discussed by Buwalda ${ }^{3}$ and more recently by Arnold and Kemnitzer. ${ }^{*}$ These reports seem to be adequate for present purposes in their treatment of the fuels of this region, which will therefore not be discussed in this bulletin.

Different types of minerals occur in the different formations of eastern Oregon, the Tertiary volcanic formations furnishing types quite different from those of the older metamorphic rocks. Minerals are chemical compounds and are formed under definite chemical and physical conditions. Geologic studies have shown that rocks are formed under different chemical and physical conditions and that consequently the minerals associated with them are only of types either

\footnotetext{
${ }^{1}$ Collier, A. J., Geology and mineral resources of the John Day region: Mineral Resources of Oregon, vol. 1 , no. $3,1914$.

${ }^{2}$ Mendenhall, W. C., A coal prospect on Willow Creek, Morrow County, Oreg.: U. S. Geol. Survey Bull. 341, pp. 406-408, 1909.

${ }^{3}$ Buwalda, J. P., Oil and gas possibilities of eastern Oregon: Mineral Resources of Oregon, vol. 3, no. 2, 1921.

"Arnold, Ralph, and Kemnitzer, W. J., Petroleum in the United States and its possessions, pp. 951-956, 1931.
} 
formed or stable under similar conditions. If the type of rock in a certain region is known, it is possible to state with reasonable certainty whether a given mineral may or may not occur there. A knowledge of geology is of great use to the prospector in saving useless search. Thus in eastern Oregon time spent on looking for gold, diamonds, and oil in areas of basaltic lavas and tuffs might have been more profitably spent in search of bentonite and other mineral resources that may occur in such regions.

Several lists of minerals from Oregon are available. In the most recent one ${ }^{5}$ the nonmetallic minerals and rocks of the eastern part of Oregon are given as follows:

$\begin{array}{ll}\text { Agate } & \text { Marble } \\ \text { Aragonite } & \text { Mirabilite } \\ \text { Asbestos (clirysotile, amphibole) } & \text { Monazite } \\ \text { Basalt } & \text { Natron } \\ \text { Borax } & \text { Niter } \\ \text { Calcite } & \text { Olivine } \\ \text { Chalcedony } & \text { Opal } \\ \text { Clay } & \text { Pumice } \\ \text { Diatomite } & \text { Salt } \\ \text { Dolomite } & \text { Sand and gravel } \\ \text { Garnet } & \text { Sapphire } \\ \text { Granite } & \text { Talc } \\ \text { Gypsum } & \text { Tuff } \\ \text { Jasper } & \text { Volcanic ash } \\ \text { Kaolinite } & \text { Zircon } \\ \text { Limestone } & \end{array}$

This list is incomplete, for it does not include great numbers of minerals such as the zeolites, which occur in many localities. The nonmetallic minerals and rocks that occur in deposits of sufficient size and quality to be economically valuable are, however, included in the list. These are diatomite, limestone, and pumice, with possibly asbestos, clay, and the salines such as mirabilite (Glauber's salts) and natron (sal soda).

\section{MINERALS AND ROCKS OF THE VOLCANIC REGIONS}

Tertiary volcanic and associated sedimentary rocks of eastern O'regon are but little altered and only through weathering. Mineral deposits in these areas therefore consist of original volcanic material, disintegration products of volcanic material, and sediments of former lake basins.

Building stone, etc.-The building stones, crushed rocks, and sand and gravel of the volcanic areas are exclusively lavas and tuffs or

\footnotetext{
${ }^{5}$ Schrader, F. C., Stone, R. W., and Sanford, Samuel, Useful minerals of the United States; U. S. Geol. Survey Bull. 624, 1917.
} 
their derivatives. In general the basaltic lavas are considered too dark in color for use as a building stone, but large amounts of the lighter-colored volcanic tuffs have been used for that purpose with great success, particularly in Baker, where the city hall, Carnegie library, cathedral, and many business blocks have been built of a light-colored tuff. ${ }^{6}$ Lavas suitable for crushed rock are found at so many places that but little difficulty is experienced by road builders in locating quarries along proposed routes. Sand and gravel are in general scarce and coarse. Considerable difficulty is experienced, especially in the Klamath Falls district, in finding sand and gravel suitable for concrete construction.

Sedimentary deposits.-The sedimentary deposits in the Tertiary volcanic area include clay, diatomite, pumice, and salines. Most of the clay is bentonitic and is the result of decomposition of the older tuff deposits. Though no deposits of high-grade bentonite have been seen, it is a material that might well be prospected for in districts served by railroads. Diatomite is of common occurrence in the Miocene and later lake beds and is of excellent quality. Deposits of this material have been studied and are described in this bulletin. Pumice occurs in both the lump form and in powder, and deposits of this material are also described. The salines of the southeastern lake region were not included in this investigation, but some information regarding them is available in earlier reports. ${ }^{7}$ Borax was at one time obtained from Alvord Lake, but the costs of production and transportation were too high to make the enterprise successful. No commercial deposits of gypsum have yet been noted in the lake beds of eastern Oregon.

Other minerals.-Agate, chalcedony, and jasper occur as common minerals filling cavities in the lavas. No commercial production of agates has been attempted, so far as known to the writer. Opaline material is abundant in the lake-bed sediments, and opals of gem quality have been found near Durkee, Baker County. Other possible gem material would include olivine (peridot), though no large crystals have been noted in the sands from the olivine basalts. The reported occurrence of sapphires in Harney County is probably based upon a confusion of small iridescent grains of olivine, quartz, or glassy feldspar with this mineral. Zeolites are common in fillings in the older lavas and in some places fill small veins in the tuffs. They do not occur in sufficient quantity to be of commercial importance. Calcite and aragonite are both common as concretions in the tuff deposits but are likewise of no economic importance.

\footnotetext{
${ }^{6}$ Parks, H. M., Preliminary report on building stone in Oregon: Mineral Resources of Cregon, vol. 1, no. 2, 1914.

7 L. S. Geol. Survey Mineral Resources for 1915, pt. 2, pp. 107-108, 1917.
} 


\section{MINERALS AND ROCKS OF THE PRE-CRETACEOUS FORMATIONS}

The pre-Cretaceous rocks include the siliceous argillites of Paleozoic and Triassic age of the northeastern part of the State, greenstones of Permian and later age, serpentines, gabbros, and granitic rocks. The rocks and minerals in this sequence are of types common in regions of moderately metamorphosed rocks.

Building stone, etc.-The pre-Cretaceous rocks are in general too shattered to furnish much building stone. The "granite" around Haines, in Baker County; the quartz diorite of Dixie Creek, near Prairie City ; and the limestones and marbles of the Wallowa Mountains and of Connor Creek are notable exceptions. They have been well described by Parks. ${ }^{8}$ Sand and gravel suitable for use in concrete occur at numerous places, especially in granitic areas. Rock suitable for road metal may be found at most localities.

Sedimentary deposits.-Some of the older sedimentary rocks include deposits of limestone and gypsum. Limestone is so rare as to be conspicuous in this region. In general it is crystalline and in some places of high purity. In the Wallowa Mountains and on Connor Creek there is white marble of good quality.

Occasionally references may be found to a gypsum deposit near Gypsum station, in the Snake River Canyon. According to Lindgren ${ }^{9} 1,800$ tons of gypsum was mined here in 1896 . There has been no production for a long time, and the large mill built has been dismantled. Lindgren gives the following section of the gypsiferous beds, which occurred near the canyon rim:

$\begin{array}{lr}\text { Gypsiferous limestone and volcanic tuff. } & \text { Feet } \\ \text { Gypsum } & 30-40 \\ \text { Red and green tuffaceous slate- } & 80 \\ \text { Gypsum } & 20\end{array}$

Slate and limestone.

The average strike of the beds is N. $60^{\circ} \mathrm{E}$. and the dip is about $30^{\circ} \mathrm{NW}$. The gypsum was completely mined out by a series of workings, and all that is now left is the unaltered anhydrite. Careful prospecting should have warned the operators of the transition of the gypsum into anhydrite and prevented the loss of capital that was incurred. Prospecting might reveal other occurrences of the anhydrite bed near the surface where weathering would have hydrated it to gypsum. It is possible that the present deposit of anhydrite might be utilized if processes investigated by the United States Bureau of Mines ${ }^{10}$ for the hydration of anhydrite can be

\footnotetext{
${ }^{8}$ Parks, H. M., op. eit., pp. 10-46.

${ }^{\circ}$ Lindgren, Waldemar, The gold belt of the Blue Mountains of Oregon: U. S. Geol. Survey 22d Ann. Rept., pt. 2, p. 753, 1901.

${ }^{10}$ Farnsworth, Marie, The hydration of anhydrite: Ind. and Eng. Chemistry, vol. 17, pp. $967-970,1925$.
} 
perfected. So far as known this is the only body of anhydrite in Oregon. No commercial gypsum deposits are known.

In places, as on Eagle Creek in the Wallowa Mountains, the limestones contain small amounts of phosphatic material, but no phosphate rock as such is known.

Placer deposits.--Small amounts of such minerals as garnet, zircon, and monazite are present in the black sand of the placers, but not in sufficient quantity to be of value.

Vein deposits.-Quartz, calcite, and barite appear in small veins and as gangue material in ore veins here and there, but not of suitable quality or sufficient size to be of economic interest.

Metamorphic deposits.-The asbestos deposits on Pine Creek, Baker County, consist of asbestiform anthophyllite which appears to have been formed by the action of magnesia-rich solutions on crushed vein walls. Small amounts of garnet occur in limestone along intrusive contacts: in the Wallowa and Blue Mountains, but no contactmetamorphic deposits of commercial size or quality are known. With the exception of serpentines derived from gabbros in the head of the John Day drainage basin, from which chrysotile asbestos has been reported, no other metamorphic rocks that contain concentrations of any economic mineral are known in this area.

\section{ASBESTOS}

The name asbestos was originally applied to the fibrous form of the mineral tremolite but now has little mineralogic significance and is used for the fibrous varieties of serpentine (chrysotile) and for several members of the amphibole group, namely, anthophyllite, crocidolite (blue asbestos), amosite, and tremolite. Commercially asbestos may be divided into varieties which furnish spinning fiber and those which do not. The most valuable of these varieties is chrysotile, which yields the greater amount of spinning fiber, although crocidolite and the unusually long-fibered amosite varieties of Rhodesia and South Africa are becoming increasingly important. Anthophyllite and tremolite, commonly referred to as amphibole asbestos, have fibers that are generally too weak for use in spinning. Anthophyllite finds its greatest use in insulation and filtration material, for which it is fitted by its resistance to heat and acids.

The United States produces little asbestos, though it consumes very large amounts.

Of the Canadian total of 242,114 short tons, valued at $\$ 8,390,163$, in 1930 , the United States took 200,068 tons (82.6 percent), valued at $\$ 5,466,783 .^{11}$

${ }^{11}$ Mineral Resources for 1930, pt. 2, p. 266, U. S. Bur. Mines, 1933. 
Asbestos sold by producers in the United States, 1921-30, by varieties

\begin{tabular}{|c|c|c|c|c|c|c|}
\hline \multirow[b]{2}{*}{ Year } & \multicolumn{2}{|c|}{ Chrysotile } & \multicolumn{2}{|c|}{ Amphibole } & \multicolumn{2}{|c|}{ Total } \\
\hline & $\begin{array}{l}\text { Short } \\
\text { tons }\end{array}$ & Value & $\begin{array}{c}\text { Short } \\
\text { tons }\end{array}$ & Value & $\begin{array}{l}\text { Short } \\
\text { tons }\end{array}$ & Value \\
\hline 1922 & $\begin{array}{r}438 \\
25 \\
69 \\
173 \\
93 \\
(1) \\
(1) \\
(1) \\
1,983 \\
3,653 \\
2,857 \\
(1) \\
(1) \\
(1)\end{array}$ & $\begin{array}{l}\$ 313,268 \\
3,320 \\
4,433 \\
33,914 \\
40,750 \\
\text { (1) } \\
\text { (1) } \\
\text { (1) } \\
317,584 \\
273,292 \\
111,708 \\
\text { (1) } \\
\text { (1) } \\
\text { (1) }\end{array}$ & $\begin{array}{l}393 \\
42 \\
158 \\
127 \\
1,165 \\
(1) \\
(1) \\
(1) \\
1,172 \\
589 \\
371 \\
(1) \\
\text { (1) } \\
\text { (1) }\end{array}$ & $\begin{array}{c}\$ 23,700 \\
6,800 \\
5,193 \\
8,585 \\
10,950 \\
(1) \\
(1) \\
(1) \\
33,420 \\
15,992 \\
7,259 \\
(1) \\
(1) \\
(1)\end{array}$ & $\begin{array}{r}831 \\
67 \\
227 \\
300 \\
1,258 \\
1,358 \\
2,981 \\
2,239 \\
3,155 \\
4,242 \\
3,228 \\
3,559 \\
4,745 \\
5,087\end{array}$ & $\begin{array}{r}\$ 336,968 \\
10,120 \\
9,626 \\
42,526 \\
51,700 \\
134,731 \\
336,882 \\
351,178 \\
351,004 \\
289,287 \\
118,967 \\
105,292 \\
130,677 \\
158,347\end{array}$ \\
\hline
\end{tabular}

1 Bureau of Mines not at liberty to publish figures.

World's production of asbestos, 1926-30, in metric tons

[Mineral Resources for 1930, pt. 2, p. 271, U. S. Bur. Mines, 1933]

\begin{tabular}{|c|c|c|c|c|c|}
\hline Country ${ }^{1}$ & 1926 & 1927 & 1928 & 1929 & 1930 \\
\hline \multicolumn{6}{|l|}{ Africa: } \\
\hline Southern Rhodesia & 30,249 & 30,097 & 36,251 & 38,677 & 34,260 \\
\hline Union of South Africa & 12,789 & 20,085 & 21,821 & 29,970 & 17,491 \\
\hline Argentina (rail and river shipments) & 38 & 1 & - n......... & $\ldots$ & $(2)$ \\
\hline $\begin{array}{l}\text { Australia: } \\
\text { New South Wales }\end{array}$ & & & & & \\
\hline $\begin{array}{l}\text { New South Wales. } \\
\text { South Australian }\end{array}$ & 5 & -1 & 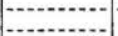 & $i$ & \\
\hline 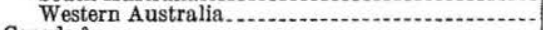 & 107 & 11 & 12 & 259 & 114 \\
\hline Canada ${ }^{3} \ldots \ldots \ldots$ & 253,469 & 249,273 & 247,690 & 277,647 & 219,641 \\
\hline China & (2) 433 & 11241 & $\stackrel{(2)}{11} 765$ & ${ }^{(2)}\left(4^{2}\right) 17$ & $(2)$ \\
\hline $\begin{array}{l}\text { Cyprus (exports) } \\
\text { Finland }\end{array}$ & $\begin{array}{l}6,433 \\
1,674\end{array}$ & $\begin{array}{r}11,079 \\
1,298\end{array}$ & $\begin{array}{r}11,765 \\
1,462\end{array}$ & $\begin{array}{r}14,017 \\
1,563\end{array}$ & $\begin{array}{l}5,487 \\
1,188\end{array}$ \\
\hline France, & 660 & 803 & 730 & 750 & (2) \\
\hline India, British. & 59 & 69 & 159 & 324 & $(2)$ \\
\hline Italy & 2,900 & 3,840 & 4,950 & 2,847 & 751 \\
\hline Japan (approximate) & 1,000 & 1,000 & 1,000 & 1,000 & 1,000 \\
\hline Russia (year ended Sept. 30) & 18,334 & 21,156 & 26,492 & (3) & $(3)^{3}$ \\
\hline 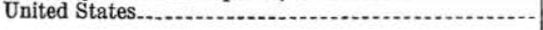 & 1,232 & 2,704 & 2,031 & 2,862 & 3,848 \\
\hline
\end{tabular}

1 Bolivia, Brazil, and Madagascar are reported to produce small quantities.

2 Data not available.

Exclusive of sand and gravel.

Asbestos has been reported from numerous localities in Oregon. Mitchell ${ }^{12}$ listed asbestos from Watson and Ontario, in Malheur County; Barite, in Wheeler County; Mount Vernon, Canyon City, and Prairie City, in Grant County; and Lakeview, in Lake County. As asbestos occurs only in definite types of rocks, which are not present in Malheur and Lake Counties, it is probable that the reported occurrences in those counties do not exist. Though it is possible that asbestos occurs in the areas of serpentine in Grant County, no deposits have been reported from these localities or investigated. Rumors of asbestos deposits in the serpentine areas in the Snake River Canyon

${ }^{19}$ Mitchell, G. M., Minerals of Oregon: Oregon Univ. Bull., new ser., vol. 13, no. 3, p. 20,1912 .

$63952-37-2$ 
are numerous, but no actual occurrences have been reported. The only prospects known are the amphibole asbestos prospects on Pine Creek, Baker County, which are described below.

\section{PINE CREEK ASBESTOS DEPOSITS}

\section{LOCATION}

Asbestos deposits occur on Pine Creek, Baker County, about 20 miles south of Baker (fig. 1), where they occupy a small area on the

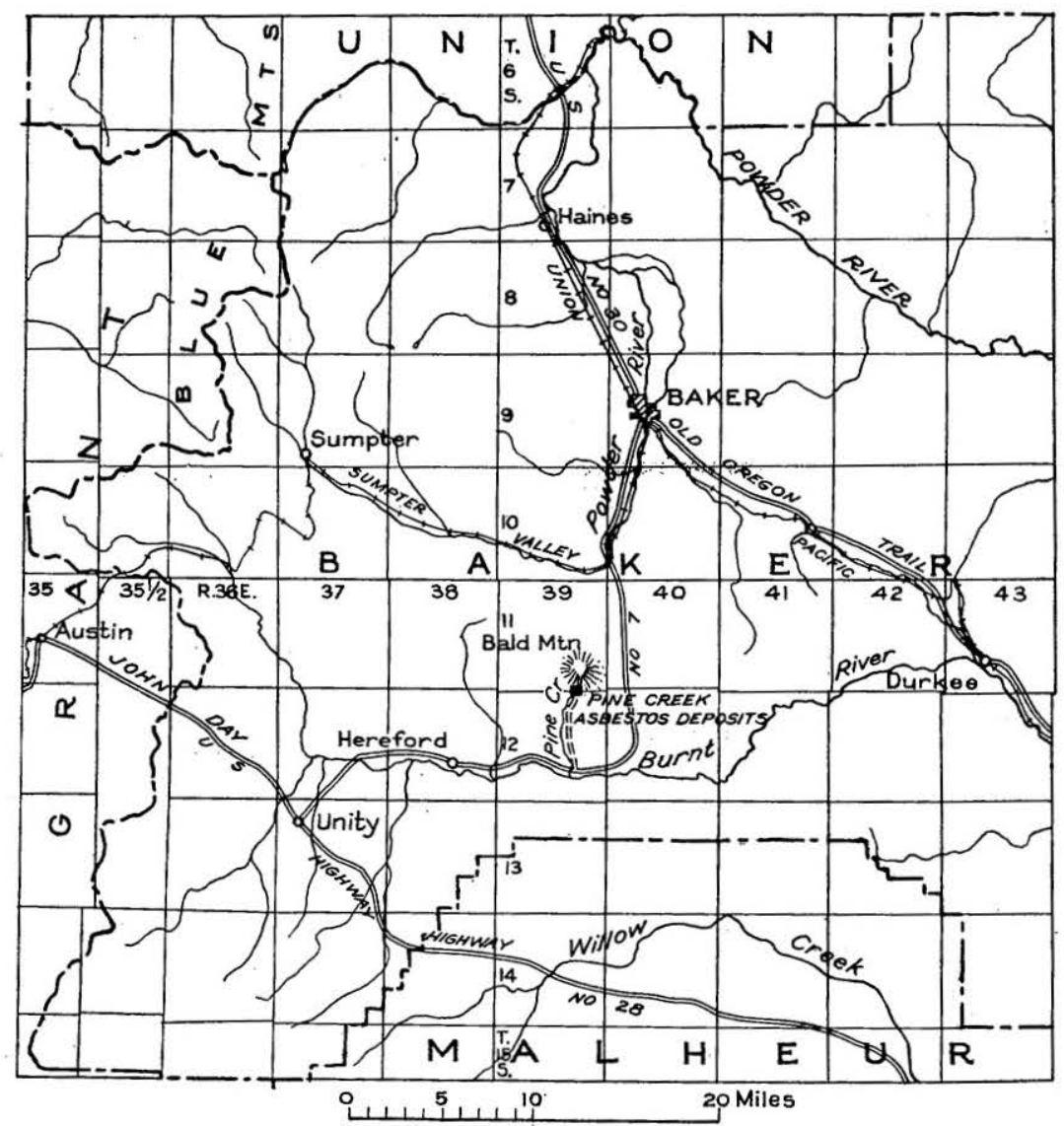

Figure 1.-Index map showing location of Pine Creek asbestos deposits.

ridge between the west fork of Pine Creek and Cow Creek and extend east to the divide between the two forks of Pine Creek.

The writer spent a week in August 1931 examining the deposits and making the accompanying map (pl. 2). The extensive soil cover in the southern part of the area made detailed mapping difficult, so that the geology as mapped is more or less generalized in places. 


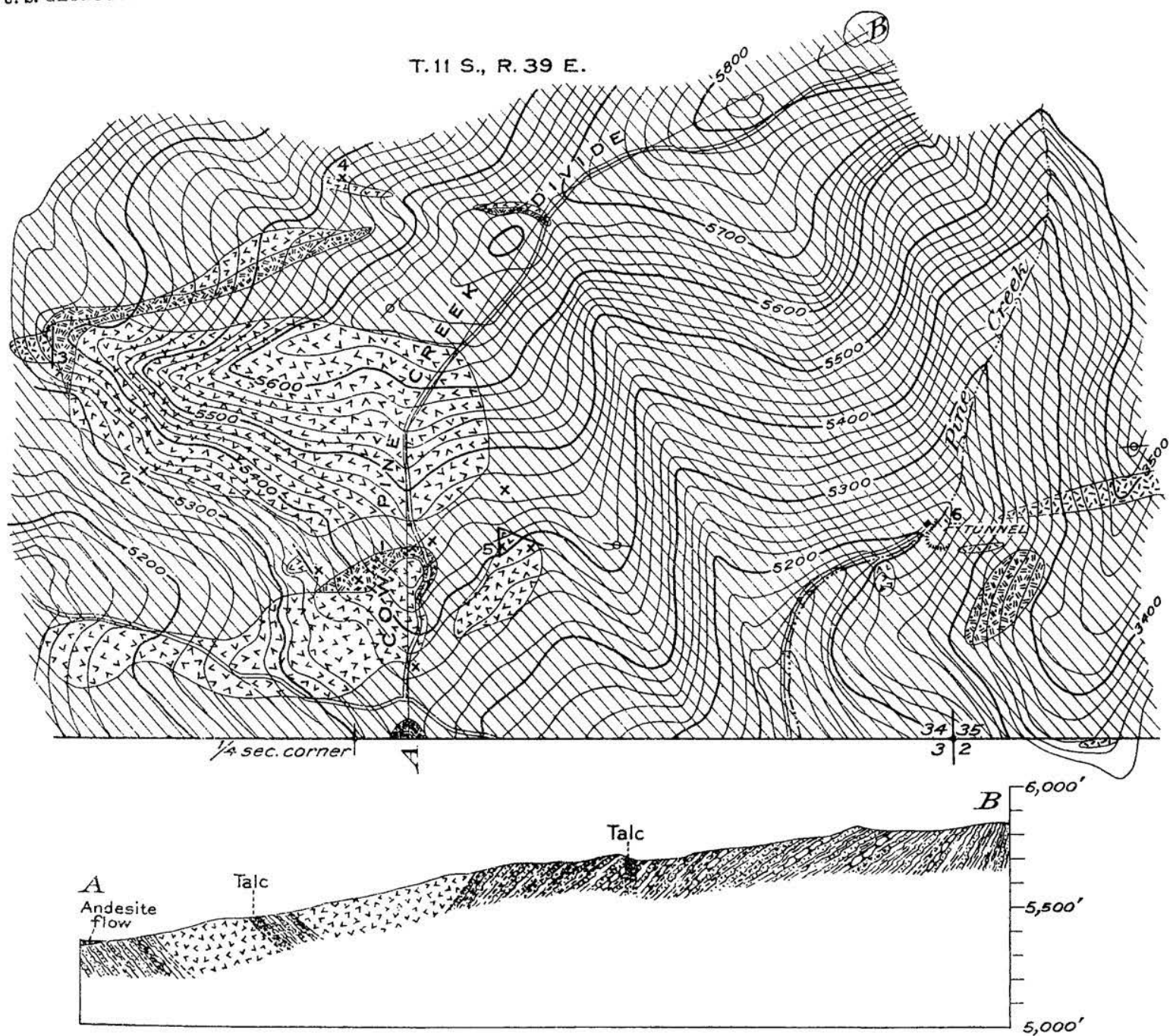

Section alonó line $A-B$

Contour interval 20 feet. Datum assumed elevation at corner of sections 34 and $35,5,200$ feet

GEOLOGIC SKETCH MAP OF PINE CREEK ASBESTOS DEPOSITS, BAKER COUNTY.

Numbers 2 to 6 indicate pits referred to in text.

\section{EXPLANATION}

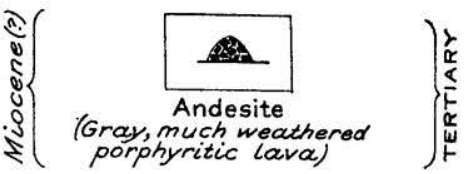

Siliceous schist (In places argillite, chert

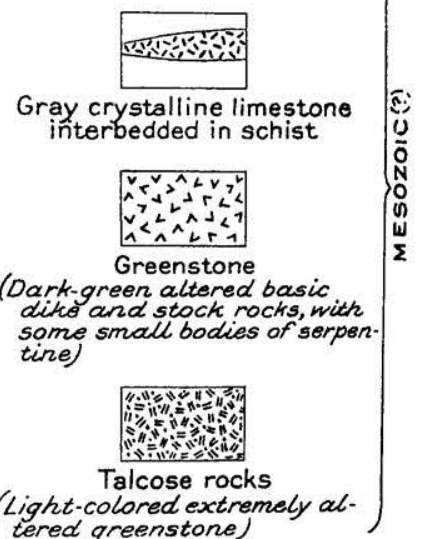

tered greenstone)

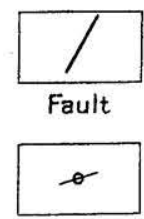

Strike of vertical beds

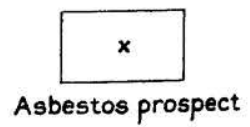


The Pine Creek asbestos deposits are in the rugged mountainous country between Baker and the Burnt River. Pine Creek, which flows south into the Burnt River, heads against Bald Mountain, 6,667 feet in altitude, about a mile north of the deposit. The divide between Cow Creek and Pine Creek, on which the greater number of prospects are located, is a spur of Bald Mountain. Within the half square mile mapped there is a maximum relief of about 700 feet.

This district is not located favorably with respect to transportation, being about 36 miles from the railroad at Baker. Of this distance, about 6 miles is covered by an unimproved mountain road and the remainder by the mountainous portion of the Baker-Unity highway.

Acknowledgments are due to Messrs. Mortensen, Larsen, and Haley, of Baker, for their willing cooperation in the investigation of this district, most of which is covered by claims belonging to them.

\section{GEOLOGY}

The Pine Creek deposits occur in a series of old, closely folded, sheared rocks, consisting of schists associated with dike rocks and sparse argillite, chert, and limestone.

\section{MESOZOIC (?) ROCKS}

Schists.-The schists are fine-grained dark-blue to white rocks, which weather to smooth slopes broken only by outcrops of more resistant siliceous beds. The attitude of these rocks is not uniform, the strike ranging from N. $50^{\circ} \mathrm{W}$. to N. $50^{\circ} \mathrm{E}$. and the dip being steep.

These rocks appear to be mainly siliceous and comprise argillites, cherts, quartz schists, and schistose tuffs. Schists form the greater part of the series, though there are small amounts of the less metamorphosed argillites and cherts.

Limestones.-Lenses of limestone are common in the schist series of this region. In general they are of small size and irregular shape. The limestone lens mapped on the divide east of Pine Creek consists of a crystalline dark-gray limestone with which is interbedded considerable sandstone. In this lens recrystallization has not progressed to a point where the limestone can be called marble. The smaller lenses farther south on the ridge are much purer and are really gray marble. These lenses have sharp, ragged boundaries, and their pattern is obviously affected by crushing and faulting.

Greenstones.- Small bodies of greenstone occur in the schists of this region in rather spotty fashion. These rocks, which form prominent dark rust-colored outcrops on the hillsides, appear to have no regular distribution or shape. In general they are irregularly jointed. In many places there is schistose cleavage, particularly along the fault zones that appear to bound all the bodies in this 
district. In the hand specimen the rock is fine- to medium-grained, with a dark-green color. In some places it is altered to a rock composed entirely of talc and magnesite, with lesser amounts of calcite, and these areas have been mapped separately on plate 2 . These talcose varieties weather to lighter-colored outcrops, which have a very rough look but feel smooth.

Serpentine occurs but rarely in these rocks. Small bands of serpentine have been found in the northern and southern greenstone bodies on the Cow-Pine Creek divide, associated with the talcose rocks. It is a dark-green to black rock, glistens in the sun, and has a shell-like fracture. In places it contains veinlets of fibrous material approaching chrysotile asbestos in appearance, but not in sufficient quality, size, or quantity to warrant prospecting. The huge "dike of serpentine" which was described to the writer by several persons and which is popularly supposed to run westward through this district was not recognized, and the writer doubts its existence except insofar as its presence may be inferred from the small exposures mentioned.

Thin sections were made of some of these greenstones. One section was composed largely of feldspar, considerably altered, with a smaller amount of uralite. Some of the less-altered feldspar crystals were andesine. In another section the dominant mineral was uralitized pyroxene with smaller amounts of albitized feldspars. In the most altered greenstones the original minerals have been changed to an intergrowth of magnesite, calcite, talc, and chlorite.

\section{TERTIARY ROCKS}

The only Tertiary rock in the area mapped in detail is a lightgray porphyritic lava. This rock occupies a small area on the CowPine Creek divide and is a representative of the flows that once covered this region.

The Tertiary gravel of the Burnt River Valley does not extend. north into this area.

\section{QUATERNARY DEPOSITS}

The Quaternary is represented in the district by soil cover and hill wash. Small amounts of rich auriferous gravel occur in Pine Creek just south of the mapped area.

\section{STRUCTURE}

The structure of this district is essentially that of a series of closely folded sediments with scattered bodies of dike rocks. Although the regional trend of the schists is close to N. $80^{\circ} \mathrm{E}$., there is considerable local variation in strike, and in detail the structure is ex- 
tremely complicated. The contact between schist and limestone is in many places a fault. All the greenstone-schist contacts that have been studied are of fault nature, both formations being crushed.

These crushed zones show no general trend. The large greenstone mass on the Cow-Pine Creek divide is entirely surrounded by a crushed zone, which dips under the greenstone at every point. Whether this zone extends completely under the greenstone is not known. Possibly it does; and if so the greenstone may be a large block of an older body that was caught in the schists during folding and moved into its present position. One block of greenstone, probably entirely surrounded by the schists, was found in the adit on the east side of Pine Creek opposite the cabin. Similar masses might be expected in driving other tunnels in the district.

\section{ASBESTOS}

\section{OCCURRENCE}

Asbestos occurs in this district in irregular crushed zones in the schists and greenstones. It is everywhere associated with talc. Although small amounts of fibrous serpentine and serpentine (chrysotile) asbestos are present in the greenstones, the only variety of asbestos here present in any considerable amount is anthophyllite.

The color of the asbestos is white to very light green. The length of the fiber bundles varies with the individual occurrence from 1 inch to 16 inches, but the average is between 4 and 10 inches. The asbestos is rather harsh, and a large amount of fibrous dust is produced when a bunch of fibers is rolled between the fingers and separated into smaller bunches. The fibers are weak compared to those of chrysotile asbestos and are rather brittle. The asbestos occurs both as slip fiber, in which the fibers are parallel to the slippage in the crushed zone, and as cross fiber, in which the fibers have grown across the vein.

Samples of the asbestos from the different prospect pits were examined under the microscope and found to be identical. Extinction is parallel to the (c) axis, the elongation is positive, and the birefringence is high. Qualitative chemical examination by J. J. Fahey, of the Geological Survey's chemical laboratory, showed it to be very low in aluminum and calcium and to contain less iron than magnesium.

The only places in which the occurrences of asbestos can be actually studied in this district are in prospect pits. Many of these are partially filled by debris, and only a few will be described here.

Occurrence in schist.-Pit 6 (see pl. 2) is dug in the bluish-gray to gray siliceous schist characteristic of the region. It is 8 feet long, 6 feet wide, and about 7 feet in maximum depth. At the bottom are several lenticular masses of altered schist, talc, and asbestos. These 
strike N. $80^{\circ} \mathrm{E}$. and dip $30^{\circ} \mathrm{S}$. The bedding approaches very closely the regional schistosity. The asbestos occurs as slip fiber and forms irregular vein masses from a few inches to a foot thick, 3 to 4 feet long, and several feet wide. On each side of the asbestos is talc that preserves the structure of the schists and grades into them within a distance of 1 foot. This is the only locality where asbestos has been noted as occurring any distance from the greenstones, though it is possible that further prospecting might reveal other localities.

Occurrence near schist-greenstone contacts.-An interesting locality (no. 1, pl. 2) in which the development of the asbestos of this district is well shown is on the Cow Creek and Pine Creek divide. Here a shallow trench has been dug along a fault contact of the schists with the serpentine facies of the greenstones. At the east end of this trench the fault contact between the two rocks is well exposed. The serpentine and schist are both crushed, and at their contact is about an inch of gouge. Of particular interest is the growth of asbestos veinlets in the projections of the schist surface. In the projection exposed in the pit, sketched in figure 2, thin irregular veinlets of white anthophyllite asbestos occur with coarsely fibrous anthophyllite and are oriented nearly parallel to the general dip of the fault. The asbestos fibers have grown in these veinlets across the direction of movement of the fault.

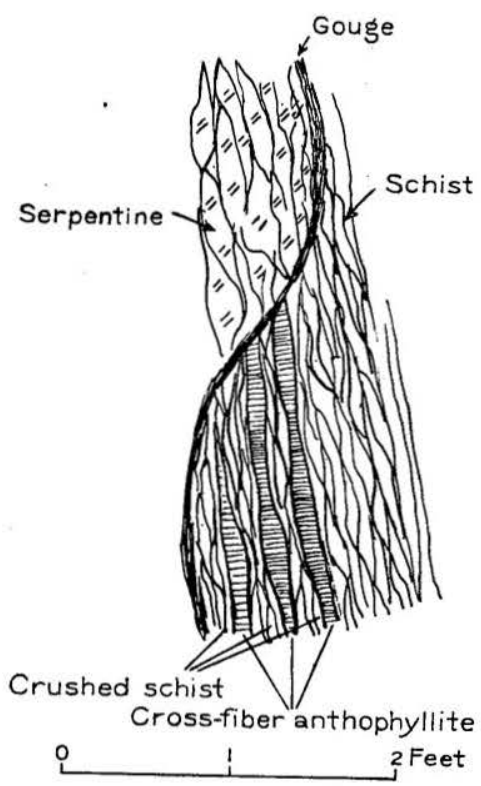

Figure 2.-Cross-fiber anthophyllite veins in crushed zone in schist.
The prospect pit from which the largest amount of asbestos taken from this district has been obtained lies along another fault contact of schist and greenstones. This pit (no. 5, pl. 2) is about 40 feet long in a northerly direction and nearly 10 feet wide in the central part. The west side is in the schist and the east side in greenstones. The schistosity in the schist and the cleavage in the crushed greenstones are parallel to the fault, which dips about $70^{\circ} \mathrm{W}$. and strikes north. The asbestos formerly occurred here as a lenticular mass in the argillite hanging wall. Mining out of this lens produced a pit some 10 feet deep, at the north end of which a thin extension of the mass has been left. A photograph of this end is reproduced in plate 


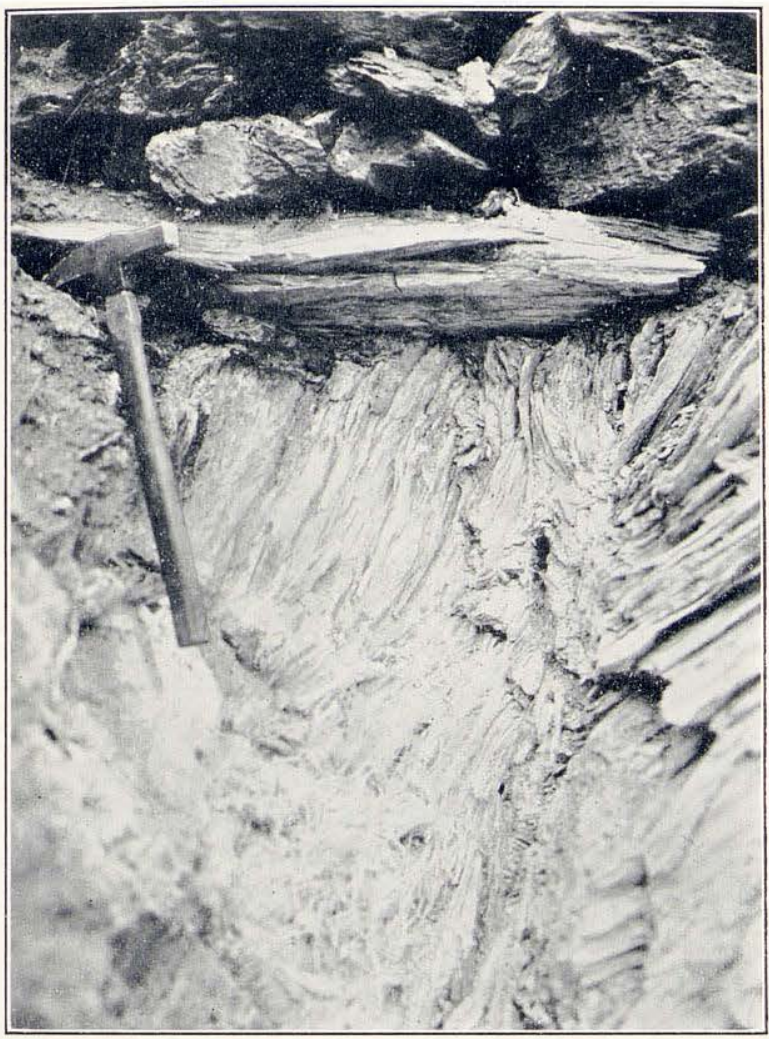

A. LONG SLIP-FIBER ASBESTOS IN PROSPECT PIT 5.

The wall on the left is in crushed schist and that on the right in greenstones. The pick handle is 14 inches long.

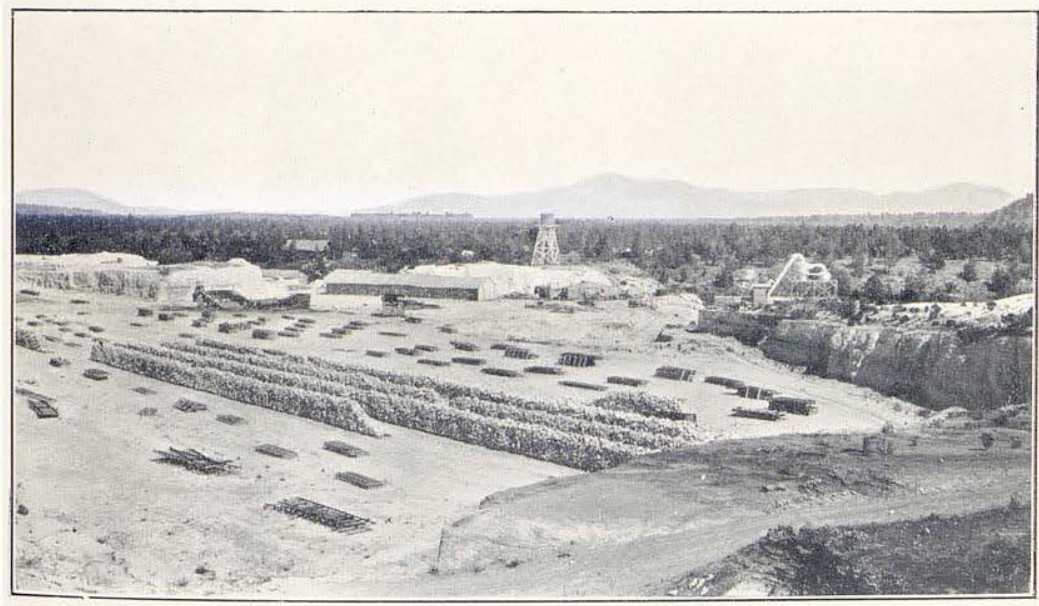

B. VIEW NORTHWEST ACROSS OUARRY OF ATOMITE CORPORATION NEAR TERREBONNE, DESCHUTES COUNTY.

Photograph by R. W. Richards. 
$3, A$, and shows that the direction of the fibers of the asbestos is parallel to the fault zone. On each side of the asbestos for a distance of 2 to 3 feet the country rock has been altered to talc.

The cut in which asbestos was first discovered in this district (no. $3, \mathrm{pl} .2$ ) is on the southwest tip of the large greenstone mass of the Cow Creek and Pine Creek divide. The fault here strikes about N. $30^{\circ} \mathrm{W}$. and dips $70^{\circ} \mathrm{N}$. The asbestos occurs in the schists that form the southern footwall. No asbestos was noted along the greenstone-marble fault contact a short distance to the north. The bottom of this pit is covered with waste, and no good exposures of the asbestos are available.

Occurrence in greenstones.-An interesting occurrence of asbestos is found in the crushed zone at the base of the large greenstone mass exposed on the Cow Creek and Pine Creek divide. At this locality (no. 2, pl. 2), which is on the south-central part of the greenstone body, a tunnel has been dug for a distance of 20 feet into the crushed zone. At the entrance to the tunnel the nearly level floor is in altered greenstones. Farther back in the tunnel the low north dip of the crushed zone carries the talc down to the level of the floor, and the north face is all in this altered material. At several places in the tunnel there are lenticular masses of fibrous talcose material a foot thick and several feet long, parallel to the direction of the crushed and altered zone. No lenses of asbestos were noted, but on the dump at the front of the tunnel considerable amounts of much-weathered asbestos were found, which, according to $\mathrm{Mr}$. Mortensen, were the remnants of several tons of material that had been mined.

A pit 20 feet deep (no. 4, pl. 2), in a greenstone body on the Cow Creek side of the district, exposes a vein of asbestos. The vein strikes roughly $\mathrm{N}$. $70^{\circ} \mathrm{E}$. and dips $40^{\circ} \mathrm{S}$. The strike corresponds closely to that of the schists at this locality. The vein is 6 to 12 inches thick and is filled with a fine white fibrous asbestos of the cross-fiber variety. Whether the vein is continuous below the bottom of the pit cannot be stated.

\section{ORIGIN}

In general asbestos is considered to occur in bodies of ultrabasic rocks. Chrysotile, or serpentine asbestos, is restricted to bodies of serpentine, which may have formed either from peridotites, as in the Canadian district, or from limestone, as in Arizona. The anthophyllite deposits of Georgia occur in peridotites, and according to Hopkins ${ }^{13}$ the slip and cross fiber varieties were formed by deposition of material collected by solution of the wall rock, in veins. In marked

\footnotetext{
${ }^{13}$ Hopkins, O. B., A report on the asbestos, talc, and soapstone deposits of Georgia : Georgia Geol. Survey Bull. 29, p. 104, 1914.
} 
contrast are the amphibole asbestos deposits of South Africa, which occur in siliceous ironstones. According to Peacock, ${ }^{14}$ the asbestos of these deposits has been formed by rearrangement of the iron oxides and silica in the ironstone, with the addition of small amounts of soda and magnesia collected from adjoining beds. Shannon ${ }^{15}$ has recorded an occurrence of ferroanthophyllite associated with galena and forming a vein in quartzite.

The asbestos in the Pine Creek deposits occurs in shear zones between schists and greenstones; the same type of asbestos occurs in both schists and greenstones; and the asbestos grades into the country rock through a talcose zone. The occurrence of the same variety of asbestos in both the greenstones and the schists shows that it was formed by solutions originating at some point beyond the immediate vein walls. The gradation of greenstone into talc along the crushed zones and the gradation of siliceous schists into talcose schists and then into talc show that the solutions reacted with the material of the wall rocks rather than merely filling fissures. The source of the solutions is not known.

According to Hopkins ${ }^{16}$ the fibrous character of the Georgia asbestos is greatly influenced by weathering, so that although cleavage and crystallization may induce the formation of the fibers, weathering is essential to the opening up of the structure. Hopkins states that at depth the Georgia anthophyllite loses its fibrous structure and passes into nonfibrous amphibole. No opportunity exists in the Pine Creek district to determine whether the fibrous character of the asbestos changes in depth.

\section{DEVELOPMENT}

The greater part of the Pine Creek asbestos district is covered by unpatented placer claims owned by a group headed by L. B. Larsen, of Baker. These claims are as follows, all in T. 11 S., R. $39 \mathrm{E}$. Willamette meridian: $\mathrm{S}_{1}^{1} / 2 \mathrm{NE}_{1} / 4 \mathrm{SW}_{1} 1 / 4$ sec. $34, \mathrm{~N}_{1}^{1} / 2 \mathrm{SE}_{1} 1 / 4 \mathrm{SW}^{1} 1 / 4$ sec.

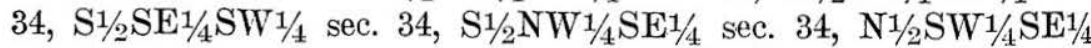
sec. $34, \quad \mathrm{~S} 1 / 2 \mathrm{SW}_{1} / 4 \mathrm{SE} 1 / 4 \quad$ sec. $34, \quad \mathrm{SW} 1 / 4 \mathrm{SE} 1 / 4 \mathrm{SE} 1 / 4 \quad$ sec. 34 ,

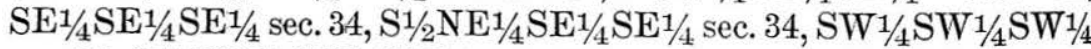
sec. 35, S1/2 NW1/4 SW $1 / 4 \mathrm{SW}^{1} / 4$ sec. 35 .

Development work already done at the time of the writer's visit in 1931 consisted of several pits, open cuts, and adits. A cabin had been built on Pine Creek, and the Pine Creek road had been extended to the cabin.

\footnotetext{
${ }^{14}$ Peacock, M. A., Nature and origin of the amphibole asbestos of South Africa: Am. Mineralogist, vol. 13, pp. 241-285, 1928.

${ }^{15}$ Shannon, E. V., Description of ferroanthophyllite, an orthorhombic iron amphibole from Idaho: U. S. Nat. Mus. Proc., vol. 59, pp. 397-401, 1921

${ }^{16}$ Hopkins, O. B., op. cit., p. 106.
} 
A few tons of asbestos has been mined out and shipped to prospective buyers as samples, but no regular production has been begun.

\section{SIZE OF DEPOSITS}

No estimate can be given of the amount of asbestos in these deposits. The largest quantity ever obtained from one pit was about 9 tons, which, according to Mr. Mortensen, was mined from the pit marked 5 on plate 2 . Inasmuch as the deposits consist of lenticular masses occurring in irregularly oriented shear zones, there is no basis for a definite tonnage estimate. The total amount of material in sight at the time of the writer's visit was less than 10 tons. Only careful prospecting will show the true size of these deposits, but it is probably small rather than large. In view of the low price which anthophyllite asbestos commands, the cost of prospecting deposits of this type should be carefully considered before further work is done.

\section{DIATOMITE}

\section{GENERAL CHARACTER}

Diatomite is a comparatively new industrial material. Small quantities have been used for a long time as an abrasive, but production in large quantity dates from the years just prior to the World War.

Diatomite is composed of the siliceous skeletons, tests, or frustules of diatoms-microscopic one-celled plants. These plants live in fresh and salt water and take an important place among the microscopic forms of life. Under favorable conditions of temperature and salinity they reproduce rapidly, giving rise to huge numbers, which on death settle to the bottom. The skeletons, together with other organic matter-clay, sand, volcanic dust, and gravel-may form considerable deposits of diatomite.

Diatomite varies considerably in appearance. Deposits of recent origin may range from black ooze to a peaty material, but older deposits in which organic matter has become dissipated through decay and other causes are commonly light in color and of firm texture. Such deposits range in composition from clay or sand containing comparatively few diatoms to earth with more than 90 percent of diatom silica.

Diatomite was first known as tripolite, from its occurrence in Tripoli. This name is still occasionally used and causes confusion with the name tripoli applied to a variety of silica left by the weathering of limestones. Diatomite is sold under many names, such as farina fossile (Italian), terre diatomacée (French), bergmehl, kieselguhr (German), infusorial earth, and diatomaceous earth. Trade 
names, such as Celite, Diato, Atomite, Featherstone, Filter-Cel, Calatom, and Pacatome, are also common. The term infusorial earth is a misnomer, because diatomite contains no essential amount of the skeletons of Infusoria-microscopic one-celled animals.

At the present time diatomite is used mainly as a filter aid, as an insulant, and as an admixture for the improvement of concrete. Both natural and treated powdered material are used in filtration, particularly of the difficultly filterable solutions of the sugar and oil industries. The diatomite, added to the liquid to be filtered, builds up a porous cake in filtration which not only filters but prevents the slimes from clogging the original filter. In insulation both the brick and the powdered forms are used. The brick may either be sawed from the natural material or may be made by adding bonding agents to the powdered substance. Powdered diatomite is commonly used in insulating dwellings and may be poured into all open spaces between walls. Unlike many other insulants it is verminproof, probably because of its fine suffocating dust. In concretes it is commonly used as an admixture to increase the ease of working, the strength, and the resistance to corrosion. It is also extensively used as a filler, because of its bulk and resistance to acids, in such things as hard rubber for battery boxes. As an abrasive it is used in preparations ranging from toothpaste to automobile polish. It is occasionally used in cosmetics, and at one time an eastern Oregon product was used in a nationally advertised brand of yeast as the absorbent for the water necessary to keep the yeasts alive.

Diatomite is so common that only the purest deposits are of value. Although considerable research is necessary to determine just what a certain diatomite may best be used for, good material may be recognized by its color, density, and freedom from grit. It should be a dead white when dry and a very light tint or white when wet, thus indicating a negligible amount of volcanic dust, clay, iron oxide, and organic matter, and should weigh no more than 20 to 35 pounds to the cubic foot, the weight depending on the degree of compaction. Deposits with thick beds and few partings are essential when it is desired to make sawed shapes, and it is desirable that the diatomite be free from lamination to avoid splitting. For use as a concrete admixture, diatomite need only be of the requisite purity. Diatomite used in filtration at present is ordinarily composed of the larger types of diatoms, but further research is needed in the other types, which have often yielded good results.

\section{WORLD'S PRODUCTION}

At the present time the United States produces the greater part of the world's diatomite. 
World's production of diatomite, 1932-34, in long tons ${ }^{1}$

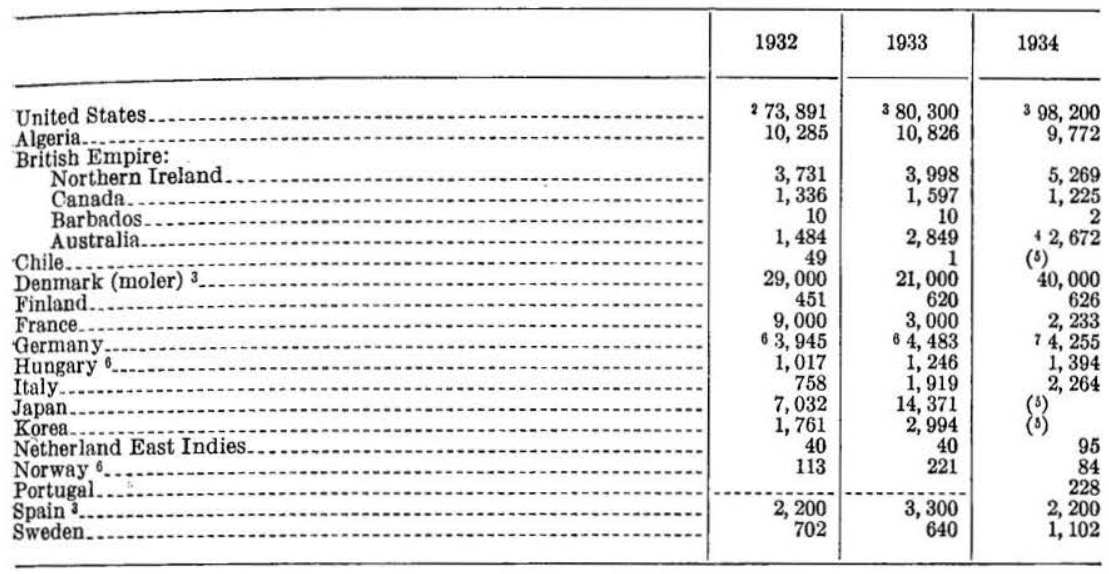

1 Mineralindustry of the British Empire and foreign countries-Diatomaceous earth, London, Imp. Inst., 1935.

2 Average of 3 years' production, 1930-32.

3 Estimated.

4 Excluding the production of Victoria, which amounted to 884 long tons in 1933.

$s$ Information not available.

O Exports.

7 Production of Hessen only.

In the United States more than 90 percent of the production comes from California. As one company produces most of this amount, figures are considered as revealing its production and are not available for recent years. The following table gives the available figures for production of diatomite in the United States:

Diatomite produced in the United States, 1919-28

\begin{tabular}{|c|c|c|c|c|}
\hline \multirow[b]{2}{*}{ Year } & \multicolumn{2}{|c|}{ Short tons } & \multicolumn{2}{|c|}{ Value } \\
\hline & $\begin{array}{l}\text { United } \\
\text { States }{ }^{1}\end{array}$ & California $^{2}$ & $\begin{array}{l}\text { United } \\
\text { States } 1\end{array}$ & California 2 \\
\hline $\begin{array}{l}1919 \\
1920 \\
1922 \\
1923 \\
1925 \\
1926 \\
1927 \\
1928\end{array}$ & $\begin{array}{l}42,642 \\
61,922 \\
355,134 \\
44,761 \\
65,833 \\
63,163 \\
73,030 \\
87,126 \\
\text { (4) } \\
\text { (4) }\end{array}$ & $\begin{array}{r}40,200 \\
60,764 \\
90,739 \\
193,064\end{array}$ & $\begin{array}{r}\$ 531,960 \\
1,079,693 \\
3683,616 \\
386,669 \\
699,406 \\
693,917 \\
922,281 \\
1,081,564 \\
(4) \\
\text { (4) }\end{array}$ & $\begin{array}{r}\$ 217,800 \\
1,056,260 \\
1,016,675 \\
5,729,736\end{array}$ \\
\hline
\end{tabular}

${ }^{1}$ Katz, F. J., Mineral resources of the United States for 1927 , pt. 2, p. 96, 1930.

${ }^{2}$ Symons, H. H., California mineral production for 1929 , p. 99,1930 .

${ }^{3}$ Partly estimated by Bureau of Mines.

4 Figures not available.

In Oregon the greater part of the production has come from the property of the Atomite Corporation at Terrebonne in Deschutes County. Companies at Harper, in Malheur County, have marketed finely divided diatomite products for filtration, admixture, and in- 
sulation since 1917 under various names. Large deposits, as yet undeveloped, in the Otis Basin in Harney County are worthy of consideration in any discussion of this resource.

\section{DIATOMITE IN EASTERN OREGON}

\section{GENERAL OCCURRENCE}

The diatomites of eastern Oregon are all of fresh-water origin. They are lake deposits and range in age from probably middle Miocene to recent. For the greater part they are of high quality, white, and massively bedded and contain a minimum of impurities, largely comminuted volcanic glass and clay. Though these deposits are apparently scattered indiscriminately over the State, a consideration of their geologic history will relate them in the reader's mind and permit their classification.

The known deposits occur only in the later Tertiary and Quaternary rocks. The Clarno and John Day formations are too highly silicified and cemented to permit recognition of such material in the field, even if they contain it. The history of these deposits begins at the time when the outwelling of the vast flows of Columbia River lavas was drawing to an end. At this period a series of lakes was formed, extensive but shallow and probably constantly changing in size. These lakes were gradually filled with fine material erupted from volcanoes and also with sediment carried in by streams. At times conditions were favorable for the growth of vast quantities of diatoms, which accumulated in certain areas in considerable thickness. The lake beds with the intercalated diatomite were covered with lavas and subjected to moderate folding, which resulted in the formation of ranges such as the Ochoco Mountains. After this mountain building began there was a renewal of erosion. In the plateau along the Columbia River these beds have been almost completely removed except at The Dalles. In the Ochoco and Blue Mountains small patches of them remain, covered by protecting blankets or cappings of lava. In these remnants are included certain diatomite deposits, like those of Indian Creek, Clover Creek, Swayze Creek, and Austin. South of the Ochoco Mountains, however, there was continued volcanic activity throughout the rest of the Tertiary period. Thus a continuous series of lavas covers the entire region, with minor thickness of lake beds and of diatomite intercalated at various places. In the downward cutting by the tributaries of the Malheur River, beds of the Payeite formation were uncovered on the south slopes of the Ochoco Mountains. In these beds occur the extensive deposits of Harper and the Otis Basin. In general the younger lavas have not been sufficiently broken and eroded to expose any deposits that may be associated with them. At Klamath Falls, however, faulting has 
exposed great areas of lake beds and diatomite, and in the Deschutes Basin, to the north, still younger lavas have been stripped away from similar deposits of Pleistocene age. In the region near the summit of the Cascade Range there are lake beds no older than historic time, and in the present Klamath Lakes deposition is still going on. These deposits may be tentatively classified as follows:

\begin{tabular}{|c|c|c|}
\hline Age & Locality & Remarks \\
\hline Active. & Klamath Lakes. & Ooze depositing on lake bottom. \\
\hline Recent. & Davis Lake. & Similar lakes exist near Crescent. \\
\hline Pleistocene. & Terrebonne, Burns. & $\begin{array}{l}\text { Old pond deposits interbedded in lavas. Terrebonne } \\
\text { deposit considered younger than that near Burns. }\end{array}$ \\
\hline Upper Pliocene. & Klamath region. & $\begin{array}{l}\text { Lake beds interbedded in lavas which lie uncon- } \\
\text { formably upon rocks regarded as equivalent of } \\
\text { Payette formation. }\end{array}$ \\
\hline \multirow{2}{*}{$\begin{array}{l}\text { Lower Pliocene to } \\
\text { probably mid. } \\
\text { dle Miocene. }\end{array}$} & $\begin{array}{l}\text { Indian Creek, Clover Creek, } \\
\text { Richland, Durkee, Austin, } \\
\text { John Day Valley. }\end{array}$ & $\begin{array}{l}\text { Remnants of formations that appear to be related to } \\
\text { Mascall and Payette of Ochoco, Blue, and Wallowa } \\
\text { Mountain regions. Age of these prob ably close to } \\
\text { that of Mascall formation. }\end{array}$ \\
\hline & Brogan, Harper, Otis Basin. & $\begin{array}{l}\text { Remnants of Payette formation buried farther south } \\
\text { by lavas. May be in part middle Miocene to } \\
\text { lower Pliocene. }\end{array}$ \\
\hline
\end{tabular}

The quality of the numerous samples of diatomite described in the following pages is set forth on pages 107-118.

\section{PREVIOUS WORK}

There is little reference to diatomite in the geologic literature of Oregon, perhaps in part because of the comparatively recent development of this substance as an industrially important material.

Russell ${ }^{17}$ in his reconnaissance of southeastern Oregon noted "fine volcanic dust" (diatomite) in the Otis Basin and the Harper district. He probably mistook the diatomite for the dust because of the interbedded coarse gray ash. Collier ${ }^{18}$ mentioned the occurrence of diatomite in the Mascall formation of the John Day Valley. Pardee and Hewett ${ }^{10}$ described briefly the diatomite around Austin, Grant County. Eardley-Wilmoti ${ }^{20}$ gave a brief account of the

${ }^{17}$ Russell, I. C., Preliminary report on artesian basins in southwestern Idaho and southeastern Oregon: U. S. Geol. Survey Water-Supply Paper 78, p. 17, 1903.

${ }^{18}$ Collier, A. J., Geology and mineral resources of the John Day region: Mineral Resources of Oregon, vol. 1 , no. 3 , p. 19,1914 .

${ }^{10}$ Pardee, J. T., and Hewett, D. F., Geology and mineral resources of the Sumpter quadrangle: Mineral Resources of Oregon, vol. 1, no. 6, p. 71, 1914.

${ }^{20}$ Eardley-Wilmot, V. L., Diatomite, its occurrence, preparation, and uses: Canada Dept. Mines, Mines Branch, Pub. 691, p. 102, 1928. 
Terrebonne deposit and mentioned the one at Harper. Calvert ${ }^{21}$ described the Terrebonne deposit, and Stearns ${ }^{22}$ quoted a report on the Terrebonne deposit by Dr. A. C. Boyle.

\section{KLAMATH LAKES}

Large deposits of diatomaceous oozes are in process of formation in the Klamath Lakes. I am indebted to P. D. Trask, of the United States Geological Survey, for the sample here described and for much information about it.

The Klamath Lakes occupy large areas in southeastern Klamath County. (See pls. 1 and 5.) At the south end of Upper Klamath Lake, near the town of Klamath Falls, there are large quantities. of gritty diatomite along the flats. Diatomite was deposited during older stages of the lake, as shown by its occurrence in stream banks. in the grounds of the Indian agency near the head of Agency Lake. The extent of these deposits is not known.

The sample collected by Mr. Trask was obtained by dredging at a point several hundred yards offshore from Point Algoma. Here the thickness of the deposit was greater than 10 feet. The dried sample is a loosely compacted grayish-white earth which contains a large amount of organic matter and some clay and grit. Kenneth E. Lohman, of the Geological Survey, has examined this material and reports as follows:

Sample 1038. Klamath Lake, Oreg., recent dredging off Point Algoma ; P. D. Trask, no. 685 (pl. 4, A).

The visible impurities in this sample consist almost entirely of organic matterand a small amount of clay. The total impurities form less than 10 percent. The range of sizes of diatoms is considerable, the distribution being as follows: 10 percent between 0.20 and 0.06 millimeters; 75 percent between 0.06 and 0.03 . millimeters; 15 percent between 0.03 and 0.002 millimeters. About 20 percent of the dredged diatoms are broken, probably owing to subsequent compaction of the dredged material. It is quite unlikely that more than 5 percent of the original material was broken in deposition. In spite of the presence of organicmatter, the diatoms are fairly clean.

The principal species of diatoms are as follows:

\section{Stephanodiscus niagarae Ehrenberg. Dominant.}

Stephanodiscus astraea rar. intermedia Fricke. Abundant.

Melosira ambigua (Grunow) Müller. Abundant.

Pinnularia nobilis Ehrenberg. Common.

Navicula cuspidata Kützing. Common.

Cocconeis placentula var. lineata (Ehrenberg) Van Heurck. Few.

Cymbella cistula (Hemprich) Kirchner. Few.

Cymbella cuspidata Kützing. Few.

Cymbella turgida Gregory. Few.

${ }^{21}$ Calvert, Robert, Diatomaceous earth, p. 44, 1930.

${ }^{22}$ Stearns, H. T., Geology and water resources of the middle Deschutes River Basin, Oregon: U. S. Geol. Survey Water-Supply Daper 637, p. 152, 1931. 
Epithemia turgida (Ehrenberg) Kützing. Few.

Epithemia zebra var. porcellus Kützing. Few.

Fragilaria construens (Ehrenberg) Grunow. Few.

Synedra pulchella Kützing. Few.

Total number of species found 25 .

This material appears to be suited for most of the purposes for which diatomite is commonly used, and, by dredging, large amounts of material could be recovered which after washing would furnish a very high grade diatomite. This process is carried on extensively at the diatomite deposits of Florida. ${ }^{23}$

\section{DAVIS LAKE}

Diatomite deposits of recent origin occur at Davis Lake, about 13 miles northwest of Crescent, Deschutes County. (See pl. 1.) Though these deposits are of no immediate economic importance they are interesting because they show the way in which other deposits, notably the one at Terrebonne, have been formed.

Davis Lake is on the eastern slope of the Cascade Range in the drainage basin of the Deschutes River (fig. 3). It is one of a number of beautiful lakes, surrounded by forests, which owe their origin to the Quaternary volcanism of the region. Davis Lake in recent dry years has shrunk considerably, and its marshes are now dry enough to support automobiles. The basin is surrounded by volcanic cones. On the west is Maiden Peak; on the southwest, Maklaks Mountain; on the southeast, Hammer Butte; on the east, Davis Mountain. The lake owes its origin to a lava flow, which welled out from the west base of Davis Mountain and dammed the old channel of Odell Creek for a length of about 3 miles and a width of $11 / 2$ miles. Though Davis Lake has no surface outlet, this lava flow is very permeable, and the lake water seeps through it to form Davis Creek, several miles below (to the north), as observed by Symons ${ }^{24}$ in 1878 .

\section{GEOLOGY}

The diatomite deposited in Davis Lake is the youngest of all the formations present, representing the last stage in the filling of Davis Lake. This lake has had an eventful history. The oldest events recorded in this locality are the formation of Maiden Peak, Maklaks Mountain, Hammer Butte, and Davis Mountain, which are volcanic cones of probable late Pliocene or Pleistocene age. The basin between these mountains was filled by sediments brought in by the forerunner of the present Odell Creek. On these sediments, which are not now exposed, pumice was deposited, part of the great pumice

${ }^{23}$ Calvert, Robert, Diatomaceous earth, pp. 84-89, 1931.

${ }^{24}$ Symons, T. W., U. S. Geog. Surveys W. 100th Mer. Ann. Rept. for 1879, appendix B, p. 218,1879 ; quoted by Russell. I. C., Preliminary report on geology and water resources of central Oregon: U. S. Geol. Survey Bull. 252, p. 117, 1905. 


\section{PLATE 4}

A. Diatomaceous ooze dredged off Point Algoma, Upper Klamath Lake, Klamath County.

1. Melosira ambigua (Grunow) Müller

2. Stephanodiscus niagarae Ehrenberg.

B. Diatomite from Davis Lake, Deschutes County.

1. Cymbella gastroides Kützing.

2. Epithemia turgida (Ehrenberg) Kützing.

3. Melosira distans Kützing.

5. Stephanodiscus niagarae Ehrenberg.

c. Sample Y4 from Terrebonne deposit, Deschutes County.

1. Fragilaria brevistriata Grunow.

2. Stephanodiscus niagarae Ehrenberg.

3. Surirella elegans Ehrenberg.

D. Sample 174 collected near Burns, Harney County.

1. Fragilaria construens (Ehrenberg) Grunow.

2. Synedra affinis var. arcus (Kützing) Grunow.

$E$. Sample 187 collected near Klamath Falls, Klamath County.

1. Fragilaria construens (Ehrenberg) Grunow.

3. Stephanodiscus carconensis Grunow.

$F$. Sample 232 collected near south end of Poe Valley, Klamath County.

1. Cyclotella operculata Kützing.

2. Melosira distans Kützing. 

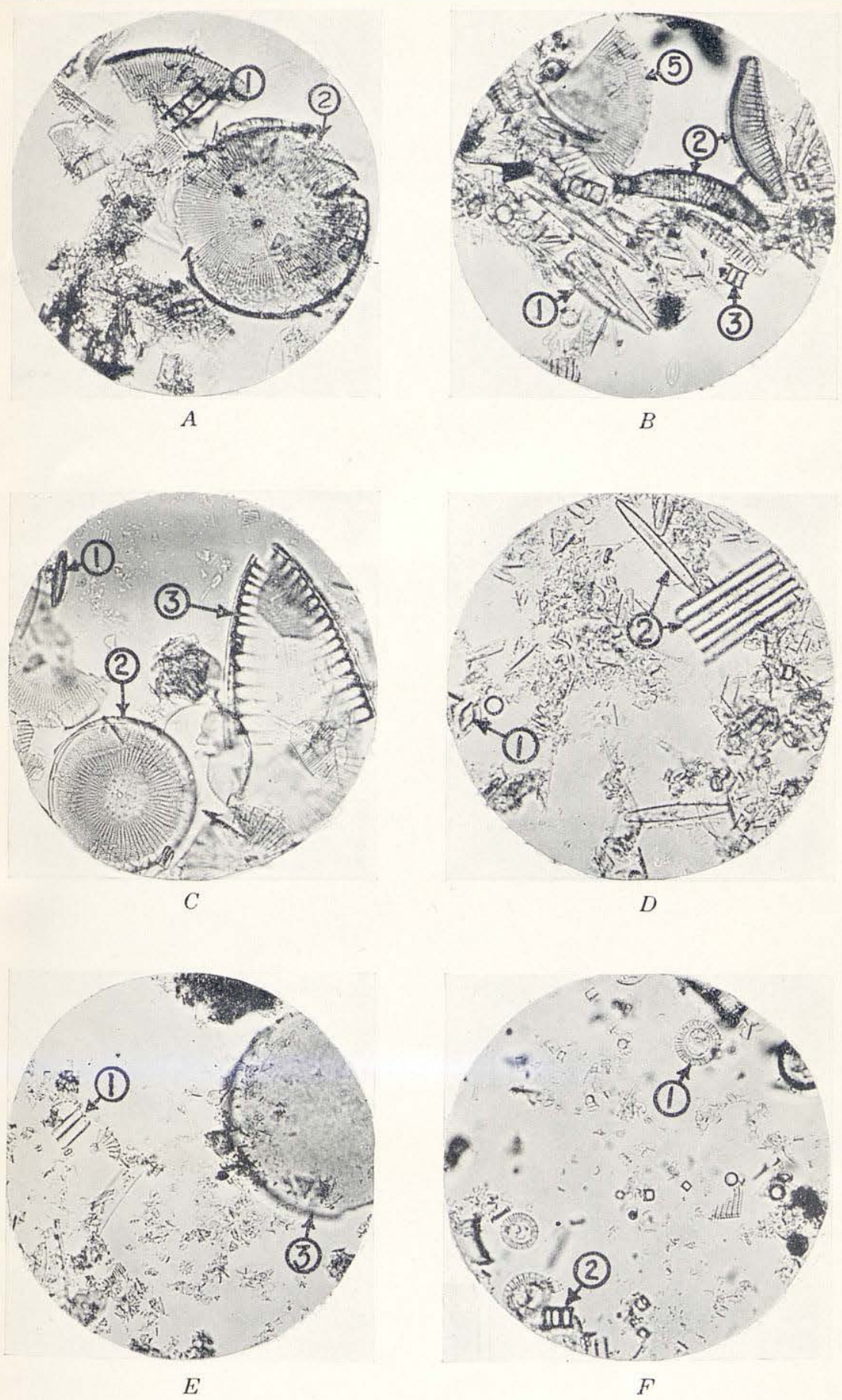

PHOTOMICROGRAPHS OF STREWN MOUNTS OF UNCLEANED DIATOMITE OF EASTERN OREGON.

Enlarged 300 diameters. Photographed by K. F. Lohman. 
sheet which has covered this region since glacial time. After this incident lava erupted from a small cone at the side of Davis Mountain, dammed the drainage, and formed a shallow lake over the entire basin. In this lake conditions were suitable for the growth of diatoms, which in the present meadows surrounding the shrinking water body of Davis Lake have formed deposits $31 / 2$ feet thick.

\section{DIA'TOMITE}

In 1931 an outcrop on Odell Creek north of the bridge in the south-central part of sec. 11, T. 23 S., R. 7 E., was visited. Here

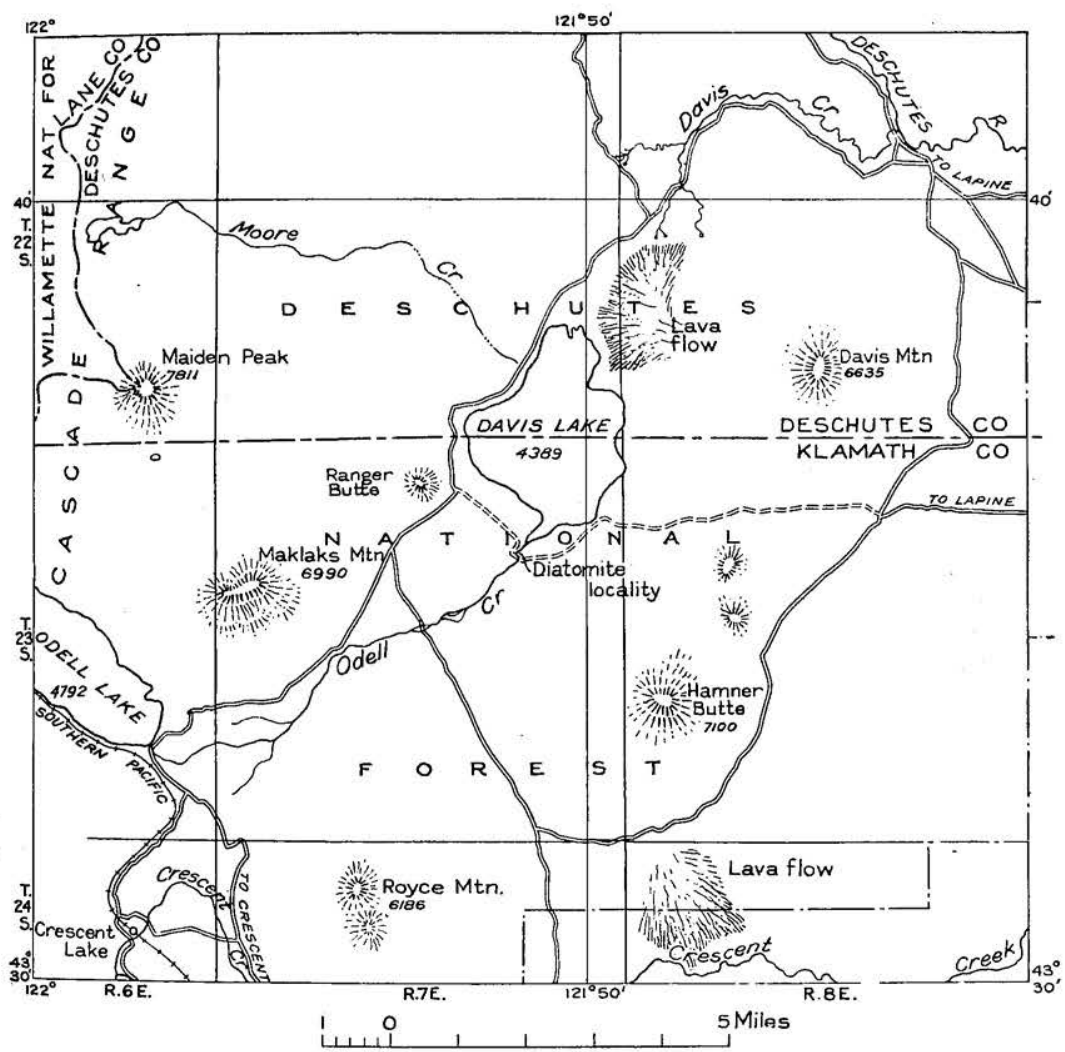

Frgure 3.- Sketch map showing location of Davis Lake.

3 feet 6 inches of diatomite overlies fine granular pumice deposits. The diatomite forms the soil of the region, and in it were found many plant roots.

The diatomite is dark colored, ranging from gray to nearly black when wet because of admixed organic material. Associated with it are many lenticular beds of pumice. In the diatomite itself are numerous granules of pumice, deposited by streams that emptied into the lake and also by the reworking of the lake bottom in storms. 
The diatomite when dry is loose and powdery but when wet can be removed in blocks. The presence of large amounts of pumice ruins it for most commercial purposes, though if it should prove suitable for use in filtration, classification by washing could furnish a high-grade product.

A portion of the sample collected was turned over to Kenneth $\mathrm{E}$. Lohman for microscopic determination, and he reports as follows:

Sample 1033, Davis Lake district, Deschutes County, Oreg., sec. 14, T. 23 S., R. 5 E.; B. N. Moore, no. 300 (pl. 4, B).

This sample contains large amounts of organic matter, clay, and volcanic ash. The diatoms are variable in size, from a maximum of 0.19 millimeter to a minimum of 0.005 millimeter. The distribution of the sizes is approximately as follows: 10 percent between 0.19 and 0.10 millimeter, 60 percent between 0.10 and 0.03 millimeter, and 30 percent between 0.03 and 0.005 millimeter. Only about 20 percent of the diatoms are broken. The individual diatoms are very dirty.

The principal species of diatoms are as follows:

Epithemia turgida (Ehrenberg) Kützing. Dominant.

Cymbella gastroides Kützing. Common.

Fragilaria brevistriata Grunow. Common.

Gomphonema acuminatum Ehrenberg. Common.

Gomphonema constrictum Ehrenberg. Common.

Gomphonema geminatum var. hybrida Grunow. Common.

Gomphonema ventricosum Grunow. Common.

Melosira ambigua (Grunow) Müller. Common.

Melosira distans Kützing.

Pinnularia nobilis Ehrenberg. Common.

Navicula radiosa Kützing. Common.

Stauroneis phoenicenteron Ehrenberg. Common.

Stephanodiscus niagarae Ehrenberg. Common.

Tabellaria ef. T. flocculosa (Roth) Kützing. Common.

Total number of species found, 28 .

\section{TERREBONNE DIATOMITE}

The most extensively developed deposit of diatomite in eastern Oregon is that owned and operated by the Atomite Corporation ${ }^{2 \mathbf{t a}^{\mathrm{a}}}$ at Lower Bridge, on the Deschutes River 6 miles west of Terrebonne, Deschutes County. The present report is based on a very brief visit by R. W. Richards and me in 1930. Acknowledgments are due to Mr. J. W. Ganong, of the Atomite Corporation, for his courtesy in allowing the examination of the corporation's property, and to Mr. W. M. Bartlett, superintendent of the plant, for much information concerning both plant and deposit.

\section{GENERAL FEATURES OF REGION}

The Terrebonne diatomite deposit is located on the Deschutes River at the west edge of the rolling lava fields which lend to this district its peculiar appearance. The deposit is small and lies under

\footnotetext{
24a According to information from the U. S. Bureau of Mines the Atomite Corporation passed into the Oromite Corporation Dec. 31, 1935.
} 
a cover of sand and gravel. Before development it appeared in the landscape only as brilliant white outcrops in the bluffs of the Deschutes River, which here flows about 100 feet below the level of the surrounding country in a narrow, steep-walled gorge.

\section{GEOLOGY}

The diatomite deposit of the Atomite Corporation occurs in the upper part of the Deschutes formation, which here blankets the older formations.

\section{DESCHUTES FORMATION}

Name.-The term Deschutes was first used by Russell, ${ }^{25}$ who described the formation under the name Deschutes sand. Stearns ${ }^{26}$ expanded the name to Deschutes formation and included the tuffs, agglomerates, diatomite, and lava flows interbedded with the sands.

Character.-According to Stearns ${ }^{27}$ the Deschutes formation is made up of

horizontal beds of yellow, brown, and black partly consolidated sand, silt, gravel, and stratified fluviatile deposits of volcanic detritus, mostly basic, intercalated with and in most places capped by basalt flows. The lower basalt flow, more than 150 feet thick, is named the Pelton basalt member, and the upper flow, 25 to $\mathbf{1 5 0}$ feet thick, is for convenience referred to as the rimrock basalt. It includes in a few places beds of white diatomite, which have a maximum thickness of 40 feet.

The general relation of these members in the region of the deposit is shown in figure 4.

The following section, which gives an idea of the composition of the upper part of the Deschutes formation, was measured in the bluff of the Deschutes River south of benchmark 2535 by R. W. Richards:

Section of bluff of Deschutes River in sec. 16, T. 14 S., R. 12 E.

Deschutes formation:

Diatomite.

Ft. in.

Slope covered by soil

Agglomerate, pink, massively bedded; weathers to cliffs; includes near center several thin beds of ashy and pebbly diatomite, and also pebbly pumice beds _- 50

Conglomerate, clean, cross-bedded, formed of basalt and andesite stream-worn pebbles

4

Agglomerate, pink; weathers brown to gray

Sand, cross-bedded, clean, coarse, black, basaltic_____-_ 15

Agglomerate, gray

Sand, coarse, clean, black, basaltic

Agglomerate, gray

Sand, coarse, clean, black, basaltic

Base of section at benchmark 2535 .

\footnotetext{
${ }^{25}$ Russell, I. C., Preliminary report on the geology and water resources of central Oregon: U. S. Geol. Survey Bull. 252, p. 90, 1905.

Stearns, H. T., op. cit. (Water-Supply Paper 637), p. 136.

"x Idem, p. 133.
} 
The diatomite at this locality ranges from 67 feet to a knife edge in thickness. Above it are more beds of coarse black basaltic sand and pyroclastic rocks, and a mile to the south it is capped by the upper rim rock basalt flow, which has been eroded away at the diatomite deposit.

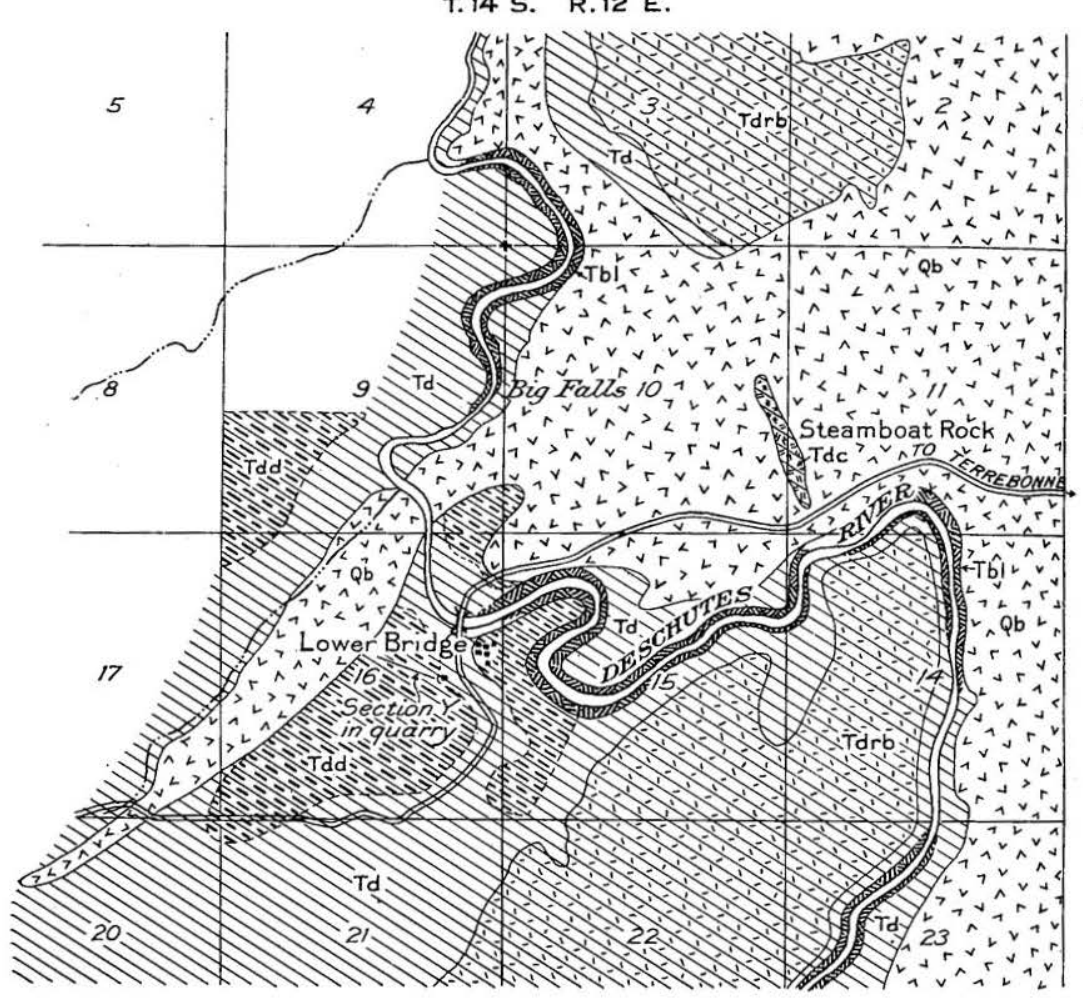

EXPLANATION

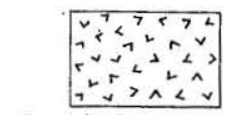

Basalt flows covering Deschutes formation

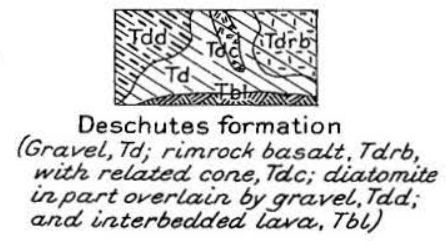

1 MILE

Figure 4.-Map of diatomite deposits at Lower Bridge, near Terrebonne, Deschutes County. Adapted from Stearns, H. T., op. cit., pl. 10 and fig. 7 .

Age and correlation.-The Deschutes formation differs markedly from other formations of eastern Oregon in both lithology and deformation. It is essentially a flat-lying series of beds formed of unconsolidated sand and gravel with intercalated lava flows and pyroclastic rocks. It is unlike the Rattlesnake formation of the 
John Day country, which is made up of gravel largely of pre-Cretaceous rocks, set in a tuffaceous matrix, and which is folded. It also differs strikingly from the Dalles formation of the Columbia River gorge, which is consolidated, folded with the Columbia River lava, and overlain unconformably by Pliocene andesites. In this region the Deschutes formation overlies the andesites of the Cascade Range, which in the Columbia River gorge are of Pliocene age, and is therefore late Tertiary or early Pleistocene.

Origin.-The Deschutes formation represents a series of fluviatile deposits formed during the interruption of the drainage of the Deschutes River by the numerous eruptions of volcanoes in this region during the later part of the building of the Cascade Range. The same process of damming of streams and the formation of lakes and meadows may be observed to the south in the ricinity of Davis Lake. The lower part of the formation records a rather continuous succession of volcanic events between filling of channels by sand, but in the upper part of the formation the existence of large ponds into which little clastic material was carried is shown by the thick deposits of diatomite. Several of these deposits are known ${ }^{28}$ and others may exist, buried under the flow of the rim-rock basalt.

\section{LATE PLEISTOCENE OR RECENT LAVAS}

Much of the surface cut in the Deschutes formation is covered by lava flows of late Pleistocene or Recent age. These lavas are formed of a vesicular basalt which has not yet weathered to the rusty browns so common in outcrops of rock of th:s type. The basalt is silver-gray on fresh fractures and is formed of labradorite, augite, and olivine. On outcrops it is black. The surface is covered with a thin loess coating, above which structural features formed during the flow, such as pressure ridges, project in a state of excellent preservation. A small tongue of this rock occurs in the gully just northwest of the quarry of the Atomite Corporation.

\section{ALLUVIUM AND LOESS}

Recent alluvium is conspicuously absent from this region, but a fine brown loess covers the entire region to depths ranging from a few inches to a foot.

\section{STRUCTURE}

The beds immediately adjacent to the Atomite Corporation's property are flat. The lenticular members of the formation are or:ginal features and are not due to deformation. The lenticular shape of the diatomite body is due to the filling of a lake which was shut off from other sources of sediment and in which diatoms flourished. There are numerous spring-fed lakes in the Cascade region today in which, if conditions were favorable, this deposit might well be duplicated.

${ }^{28}$ Stearns, H. T., op. cit., p. 152. 


\section{DIATOMITE}

\section{OCCURRENCE}

The Terrebonne deposit of diatomite is small in comparison with some others in eastern Oregon. The greater part of it is covered by sand and gravel, and there are no outcrops except in the bluffs along the Deschutes River and in several canyons. Exploratory work of the Atomite Corporation has included the digging of 83 test pits, which show, according to Mr. W. M. Bartlett, ${ }^{29}$ of the corporation, that the deposit underlies nearly 830 acres. These pits show the maximum thickness of the deposit to be 67 feet and the mean thickness to be 36.7 feet. The diatomite contains only a few seams of foreign matter, but the deposit is by no means homogeneous. The following section was measured from the base of the diatomite at the mill to the topsoil cover at the west side of the quarry.

Section in diatomite measured in. Atomite Corporation quarry from base at mill to west side of quarry in sec. 16, T. 14 S., R. $12 \mathrm{E}$.

Soil F't. in.

Deschutes formation:

Sand and gravel, coarse, black, basaltic

Diatomite, impure, yellow, sandy, incoherent

Diatomite (sample $\mathrm{Y} 7$, top of member; sample $\mathrm{Y} 6$, 8 feet 6 inches above base; sample Y5, 2 feet 6 inches above base)

Sand, black, basaltic, associated with about 1 inch of shaly diatomaceous earth above and below

Diatomite (sample Y4, 10 feet abore base; sample Y3, 6 feet above base; sample Y2, 11/2 feet above base) 12

Sand, yellow

Diatomite

Agglomerate.

The diatomites of this deposit are but loosely consolidated and rather earthy in texture. In some places there appears to be a trace of bedding, but for the most part the material is massive.

Sample Y4, which represents the highest quality material collected, was submitted to the chemical laboratory of the United States Geological Survey for analysis, with the following results:

Analysis of diatomaceous earth from sec. 16, T. 14 S., R. 12 E.

[E. Theodore Erickson, analyst]

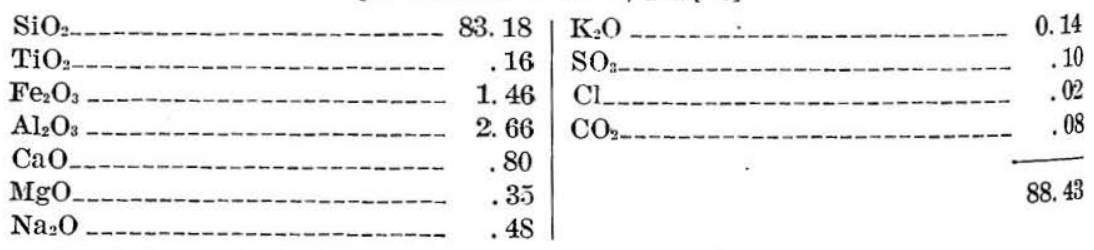

Remainder water and organic matter to make 100 percent.

${ }^{20}$ Oral communication. 
Sample Y4 was submitted to Kenneth E. Lohman, of the United States Geological Survey, for microscopic examination. Mr. Lohman reports as follows:

Sample 1028, Terrebonine, Deschutes County, Oreg., sec. 16, 14 S., R. 12 E.; B, N. Moore, no. Y4 (pl. 4, $C$ ).

Small quantities of volcanic ash and clay constitute the only visible impurities in this sample. The range of sizes of the diatoms is very great, being approximately as follows: 10 percent smaller than 0.03 millimeter; 50 percent between 0.03 and 0.10 millimeter; 30 percent between 0.10 and 0.20 millimeter; and 20 percent between 0.20 and 0.30 millimeter. Approximately half of the diatoms are broken, the fragments being included in the above percentages. The diatoms are fairly clean.

The principal species of diatoms are as follows:

Stephanodiscus niagarae Ehrenberg. Dominant.

Stephanodiscus niagarae var. magnifica Fricke. Abundant.

Cocconeis placentula Ehrenberg. Common.

Cymbella cistula (Hempr.) Kirchner. Common.

Cymbella prostratum (Ralfs) Brun. Common.

Epithemia turgida (Ehrenberg) Kützing. Common.

Epithemia zebra var. saxonica Kützing. Common.

Fragilaria brevistriata Grunow. Common.

Fragilaria pinnata Ehrenberg. Common.

Navicula bacillum Ehrenberg. Common.

Pinnularia nobilis Ehrenberg. Common.

Navicula radiosa Kützing. Common.

Surirella elegans Ehrenberg. Common.

Surirella robusta Ehrenberg. Common.

Total number of species found, 33 .

There is considerable variation from one layer to the next in the properties of the Terrebonne diatomite. Although I have done no detailed work on the deposits, the variation in weight and color in the different beds appears to bear out the statement of the Atomite Corporation that the different beds have different diatom floras, which fit them for different uses.

\section{CONCLUSIONS}

The size of this deposit has been estimated by Dr. R. C. Doyle, ${ }^{30}$ of the Union Pacific Railroad, to be about 9,000,000 cubic yards of recoverable diatomite. This estimate appears to be correct from the data available. No information is available about the amount mined.

The Terrebonne diatomite ranges from fair to excellent in quality. Even without the benefit of past experience in its use, it is believed that so far as size and shape of diatoms and purity of the earth are concerned, material from this deposit would be considered suitable for all purposes for which powdered diatomite is commonly used.

${ }^{30}$ Stearns, H. T., op. cit., p. 152. 
For the manufacture of natural sawed or cut shapes, however, it is entirely unsuited, because of its loose texture.

\section{DEVELOPMENT}

This deposit has in the past produced large tonnages of material. Plate $3, B$, is a view across the quarry of the Atomite Corporation, taken in 1930, looking northwest. Lumps of diatomite stacked for drying may be seen in the foreground; and to the right, just over the rim of the gully, the cyclones of the mill may be distinguished. The mill, which is mostly hidden by the wall of the gully, consists of a rotary kiln which dries the diatomite taken from the quarry, a pulverizer, and an air-classifying device of which the cyclones are an integral part. If it is desired to use the air-dried diatomite the kiln may be left idle, but according to Mr. Bartlett it may prove more economical to dispense with air-drying and use the kiln for calcined products. The building to the left in the juniper grove is the plant office and laboratory. In the distance is the low mound of Steamboat Rock, and in the extreme distance are the mountains forming the southwest extremity of the Ochoco Range.

When risited in 1930 the Atomite Corporation was rebuilding the mill that had burned down. The corporation owned some 762 acres in secs. 9, 15, and 16, T. 12 S., R. 14 E. The present status (1934) of the company is not known to me.

During active periods mining of the diatomite was accomplished by stripping away the overlying sand and gravel by steam shovels and then mining the earth in a series of benches. The quality of the earth varies from one stratum to the next, and considerable care was taken to keep the mined product uniform. Several elaborate schemes for drying the material were devised and used here, but at the time of the visit in 1930 all milling was being done upon airdried material. To obtain proper-sized lumps for stacking, mining was all done by hand, the laborers being provided with tridentlike forks with which slabs of the earth were broken from the quarry face. The use of powder was avoided because it shattered the fragile diatomite too much.

Material has been milled for use as concrete admixture, for filtration, and for insulation. According to Mr. Bartlett, the filtration material weighs at the screen $91 / 2$ pounds per cubic foot, and 91 percent passes a 300 -mesh screen; the admixture material weighs at the screen $101 / 2$ pounds per cubic foot and 80 percent passes a 300 mesh screen. Of the material for insulation, 60 percent is $3 / 4$-inch size and the rest consists of fines; the total weighs 12 pounds per cubic foot. Though the greater part of the material milled and sold has been used for the above-named purposes, smaller quantities of 
the highest-grade material have been used as an ingredient to keep a nationally advertised brand of yeast in a moist condition, and a shipment of 40 tons of the finest material was sent to Paris, France, for use in cosmetics, according to Mr. Bartlett.

Although the diatomite of this deposit is of high quality, developmental difficulties have been experienced. From a consideration of the excellent quality of the material there is a prospect of further production under more favorable business conditions.

\section{DIATOMITE NEAR BURNS}

A small deposit of diatomite was noted in a road cut on the Central Oregon Highway 14.8 miles west of Burns, in sec. 32, T. 23 S., R. $29 \mathrm{E}$.

\section{GEOLOGY}

The rocks of this region consist of lavas and lake beds of later age than the series of Pliocene lavas that come above the Payette formation to the east. At the locality from which the diatomite was collected the following section was exposed:

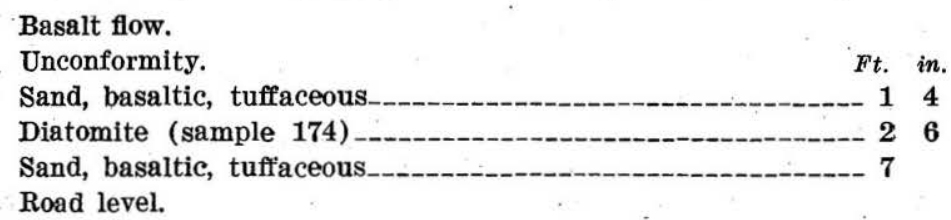

The lava flow consists of a fine-grained vesicular basalt, which covers large areas in this region. The surface of the flow is little eroded, has little soil upon it, and in places shows original structural features such as pressure ridges, formed by the buckling of the stiff crust during the flowing of the molten lava. This flow lies upon a series of sand and diatomite beds with a pronounced unconformity which, however, has but little time significance. The beds below it consist of fine- to coarse-grained black to gray basaltic sand with considerable volcanic dust. Of particular interest is the diatomite bed, which consists of a fine white earth, massively bedded. This bed, though sharply separated from the sands, shows no trace of an erosional unconformity and therefore may be taken to represent a quiet period during sedimentation in a pond.

\section{DIATOMITE}

This deposit consists of massively bedded diatomite of good color and fair weight. There is no noticeable amount of grit. The diatomite is of commercial quality, but the location of the deposit with respect to transportation and its small size will prevent it 
from becoming of any economic importance. The areal extent of the bed is unknown but is probably less than 500 acres.

A microscopic examination of the sample has been made by Kenneth E. Lohman, who reports as follows:

Sample 1032, Burns, Harney County, Oreg., sec. 32, T. 23 S., R. 29 E.; B. N. Moore, no. 174 (pl. $4, D$ ).

The visible impurities in this sample consist of considerable amounts of clay, volcanic ash, and possibly some lime. The range in size of the diatoms is considerable, the distribution of the various sizes being approximately as follows: 60 percent between 0.06 and 0.02 millimeters, 20 percent between 0.02 and 0.005 millimeters, and 20 percent between 0.005 and 0.001 millimeter. Although fully 40 percent of the diatoms are broken, the dominant form, synedra affinis var. arous, is nearly always whole. The diatoms are fairly dirty, owing to clay and possibly lime.

The principal species of diatoms are as follows:

Synedra affinis var. arcus (Kützing) Grunow. Dominant.

Fragilaria construens (Ehrenberg) Grunow. Abundant.

Fragilaria elliptica Schumann. Abundant.

Fragilaria pinnata EhrenDerg. Common.

Cocconeis placentula Ehrenberg. Common.

Coscinodiscus sp. Few.

Epithemia zebra var. porcellus Kützing. Few.

Melosira solida Eulenstein. Few.

Anomoeneis sculpta (Ehrenberg) Cleve. Few.

Rhopolodia gibba (Kützing) Müller. Few.

Cymbella australica Schmidt. Rare.

Navicula gastrum var. placentula (Ehrenberg) Van Heurck. Rare.

\section{KLAMATH DIATOMITE DEPOSITS}

\section{LOCATION}

Diatomite deposits occur in Klamath County in the region bounded by meridians $121^{\circ} 15^{\prime}$ and $122^{\circ}$ and parallels $42^{\circ}$ and $42^{\circ} 40^{\prime}$. These deposits are all of the same general age and occur in the vicinity of Chiloquin, Klamath Falls, Poe Valley, Sprague Valley, Alkali Valley, and Bonanza. (See pl. 5.)

\section{INVESTIGATION}

No literature is available concerning the diatomite deposits of this region. I spent a week in 1930 in a reconnaissance of the Klamath quadrangle.

\section{GENERAL FEATURES OF DISTRICT}

\section{GEOGRAPHY}

The Klamath diatomite district is in the western part of the basin ranges of eastern Oregon and is characterized topographically by a 
R. 8 E.

R.9 E.

R.10 E.

R.11 E.

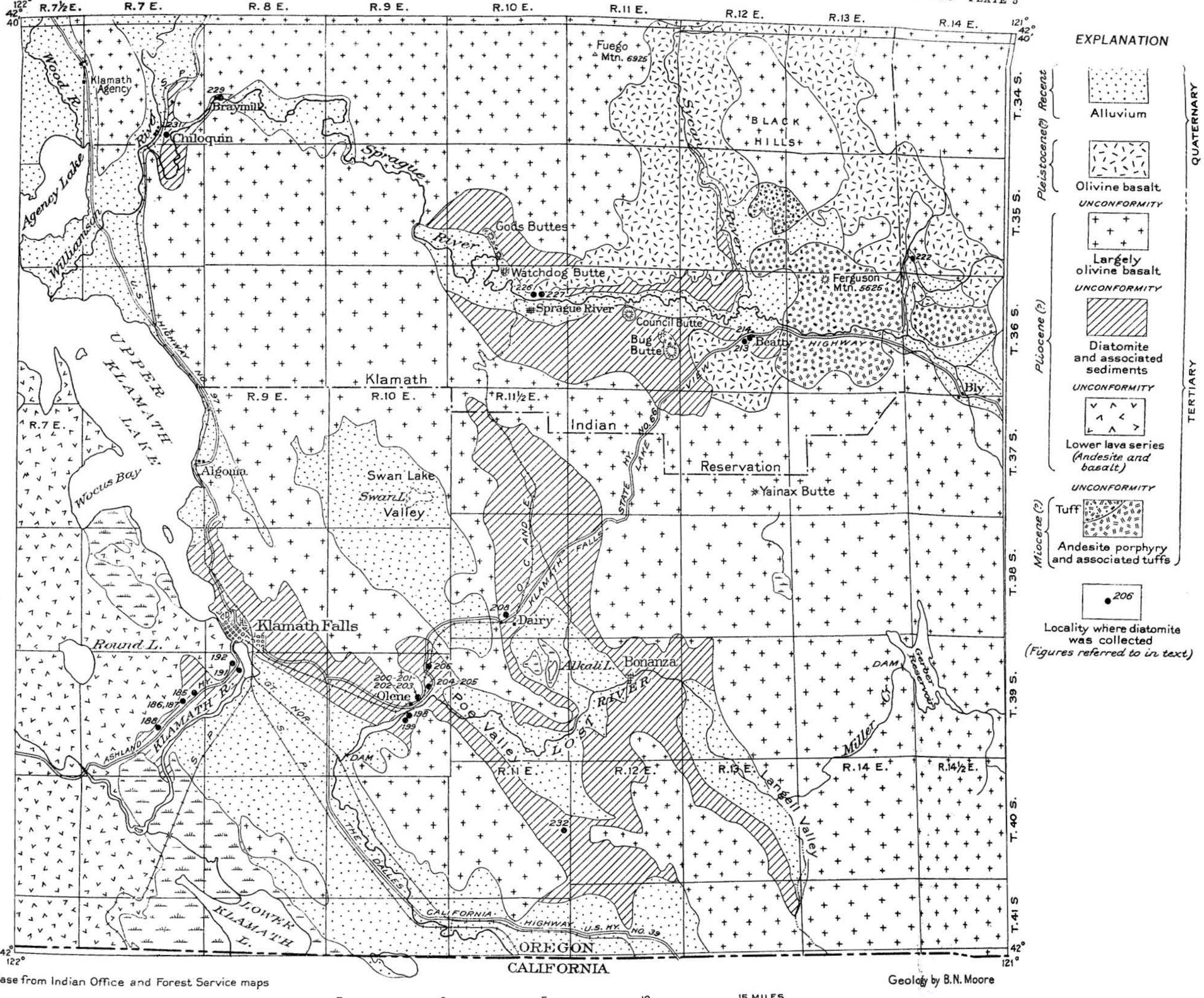

SKETCH GEOLOGIC MAP OF THE KLAMATH DIATOMITE DISTRICT, KLAMATH COUNTY. 
series of valleys and ranges of fault origin. The general altitude of the valleys is between 4,000 and 4,500 feet and of the mountains between 6,000 and 8,000 feet. Faulting in this region has been comparatively recent, and the scarps of the mountains are fresh and well defined. The most striking feature of the region to the visitor is the chain of fresh-water lakes, known as the Klamath Lakes, which occupy the depressed area just east of the Cascade Range. All the streams of the region drain into them, and the Klamath River, their outlet, empties into the Pacific Ocean through northern California: Upper Klamath Lake is about 20 miles long and 8 miles wide. It is now being filled by diatom deposits and by sediments brought in by streams. The lake was formerly more extensive, as shown by the great meadow country around the town of Fort Klamath. There are basins to the east of the Klamath Lakes, such as Swan Lake Valley, Poe Valley, Alkali Valley, and Langell Valley, all drained by the Lost River. The Sprague River Valley cuts across the northern part of the area and thus across the general structure of the region. It is narrower in its passage through the hills and becomes wide again in the lower country. In its broader places it contains many isolated hills, such as Council Butte, which, being composed of rocks more resistant to erosion than the other rocks, have been preserved during the downcutting of the region by the stream.

\section{ACCESSIBILITY}

The Klamath Falls region is easily accessible by three highwaysthe Dalles-California Highway, the Lakeview Highway, and the highway to Ashland. These highways are well graded, and the first two are paved. The region is served by the main lines of two railroads, the Southern Pacific and the Great Northern. The central part of the region is served by the Oregon, California \& Eastern Railway, which carries much of the lumber from the Sprague River region to Klamath Falls.

\section{GEOLOGY}

The rocks of the Klamath diatomite district are all of Tertiary and Quaternary age and with the exception of the diatomite and alluvium are directly or indirectly of volcanic origin. As shown on plate 5 , the greater part of the region is occupied by lava flows of several ages, which form the higher areas, whereas the valleys are commonly underlain by diatomite. The oldest exposed rocks are andesites, which are presumably correlatives of the rocks of the Payette formation, to the east. Overlying these rocks is a series of Pliocene (?) basalts and andesites with intercalated diatomite and lake beds, which in turn are covered in places by Pleistocene (?) 
lavas and Recent alluvium. These formations and their relations are briefly summarized in the following table:

Stratigraphic sequence in the Klamath Falls diatomite district

\begin{tabular}{|c|c|c|c|}
\hline Age & Formation & Character & $\begin{array}{l}\text { Thick. } \\
\text { ness (feet) }\end{array}$ \\
\hline Recent. & Alluvium. & $\begin{array}{l}\text { Valley and lake fill, usually fine soil with some di- } \\
\text { atomite. }\end{array}$ & 0,50 \\
\hline \multirow[t]{2}{*}{ Pleistocene (?). } & Olivine basalt. & $\begin{array}{l}\text { Thin flow of open-textured olivine basalt capping } \\
\text { terraces. }\end{array}$ & 50 \\
\hline & Olivine basalt. & $\begin{array}{l}\text { Thick series of flows of open textured olivine basalts } \\
\text { with some hypersthene andesites. No pyroclastic } \\
\text { material noted. }\end{array}$ & $1,100+$ \\
\hline \multirow[t]{2}{*}{ Pliocene (?). } & $\begin{array}{l}\text { Diatomite. } \\
\text {-Unconformity - }\end{array}$ & Diatomite with associated tuffs and clays. & $500+$ \\
\hline & Olivine basalt. & $\begin{array}{l}\text { Open-textured fine-grained basalt weathering blue- } \\
\text { black. Base not exposed. }\end{array}$ & $1,000+$ \\
\hline Miocene (?). & $\begin{array}{l}\text {-Unconformity- } \\
\text { Andesite. }\end{array}$ & $\begin{array}{l}\text { Stocks of andesite and some related agglomerates. } \\
\text { Overlapped by younger formations. Probably } \\
\text { correlative of Payette formation to east. }\end{array}$ & \\
\hline
\end{tabular}

MIOCENE (?) ROCKS

The oldest rocks in this district are andesite, of which the promnent stock capped by Ferguson Butte, on the Sprague River, is the most conspicuous. Smaller masses of the same formation occur in Bug Butte and Council Butte, separated by later lavas from the main mass. A small area of agglomerate forms Watch Dog Butte and is probably related to the same rocks.

The andesite forming these buttes is a light-gray porphyritic rock which weathers to a red soil on gentle slopes but spalls off on steep slopes to form prominent light-gray rocky outcrops. The rock is glassy and contains phenocrysts of plagioclase feldspar and biotite mica and long lath-shaped crystals of hornblende. Under the microscope the plagioclase phenocrysts are found to range from oligoclase to andesine.

No structural study was made of Ferguson Butte nor of the smaller buttes, but the thickness of the glassy lavas and the presence of pumiceous agglomerates in Watch Dog Butte and at other localities suggest that Ferguson Butte is the site of an old volcano. The smaller buttes might be considered as representing smaller volcanoes.

The age of these rocks is not accurately known. For similar rocks in the Fort Rock Basin Waring ${ }^{31}$ suggested an Eocene age, on the

${ }^{\text {si }}$ Waring, G. A., Geology and water resources of a portion of south-central Oregon: U. S. Geol. Survey Water-Supply Paper 220, p. 22, 1908. 
basis of a Miocene age for the later lavas, which were then supposed to be correlatives of the Columbia River lava. However, the relief of more than 2,000 feet shown by these rocks does not fit in well with an Eocene assignment. It is believed that had they been Eocene, erosion in Oligocene and Miocene time would have reduced them to an insignificant relief. It is more probable that they are of Miocene age, correlatives of the siliceous intrusive rocks of the Payette formation, which occur so abundantly in the region to the east.

\section{PLIOCENE (?) ROCKS}

The greater part of the rocks of the Klamath district belong to a series of lavas and lake beds that occupy a position in the structure of the Cascade Range analogous to that of the basalts and andesites, which overlie unconformably the upper Miocene or Pliocene sediments in the vicinity of the Columbia River gorge. This series of rocks can be traced westward into the Cascade Range, where it forms the platform upon which the volcanic cones forming the present high peaks of the summit were built. To the east, in the Fort Rock region, the series lies upon sediments that greatly resemble the Payette formation. In general lithology the lavas of the series resemble the post-Payette lavas of Malheur and Harney Counties, and the diatom floras of the diatomite have an aspect decidedly different from that of the floras of the Payette and Mascall formations. Although no direct fossil evidence aside from the diatoms is available, this series of rocks is tentatively referred to the Pliocene.

Lower lavas.-The lower portion of this series is formed of a succession of lavas more than 1,000 feet in thickness and consisting dominantly of olivine basalts. Excellent outcrops of these rocks occur along the road from Ashland to Klamath Falls and in general over the eastern part of the region to which they are restricted.

These lavas are composed of flows with very little tuffaceous or even scoriaceous material. The flows, like other basalts of eastern Oregon, are rusty brown, and have columnar jointing. On freshly fractured surfaces, however, a striking difference between these rocks and older lavas may be noted. Unaltered specimens have a silvergray to gray color, a noticeably open texture, and a high apparent density. A typical sample collected in the southwest corner of sec. 28, T. 9 S., R. 8 E., was examined under the microscope. The feldspar is labradorite, which forms a network of small lath-shaped crystals. Surrounding the feldspar are augite and olivine crystals with small amounts of magnetite; in the interstices between the feldspar laths are small brilliant olivine crystals which only partly fill them. The weathered outcrops of this rock afforded specimens of 
a typical blue-black dense basalt. No open structure was noted, though the rock was not as heavy as the fresh gray material. Under the microscope this rock resembles closely the silver-gray basalt in the texture of the feldspars, but the augites and olivines have been altered to chlorite, which completely fills the original interstices of the rock.

Diatomite.-The diatomite in this region occurs with interbedded clay and volcanic ash as a moderately thick formation separating the lower and upper lavas. No exact measurements of the thickness have been made, but it is estimated to be over 500 feet. The diatomite crops out over large areas, particularly in the flat region around Klamath Falls, near Chiloquin, in the Sprague River Valley, in Alkali Valley, in Langell Valley, and in Poe Valley.

The diatomite has a massive appearance and forms beds from a few inches to 50 feet thick. Accompanying the diatomite are gravel, sand, clay, and local beds of tuff and agglomerate. The diatomite itself is generally buff and not dead white like that of other districts. It weighs generally between 40 and 45 pounds to the cubic foot and is gritty, though there are beds of lighter material, free of grit. Possibly in the course of the rapid reconnaissance here described some beds of high-grade material were overlooked.

The relations of the diatomite to the underlying lavas are well shown in the road cuts along the Ashland Highway a mile south of Klamath Falls. Here it rests on the eroded edges of a flow and has large boulders of rock from this flow in it. The relations of the diatomite to the overlying lavas are well shown in the railroad cuts in the Lost River gorge, near the post office of Olene. The lavas that form the main mass of the mountains rest here on an irregular surface that cuts across the bedding of the diatomite.

Upper lavas.-The upper lava series of the Pliocene (?) sequence in the Klamath district consists of flows of olivine basalt and hypersthene andesite. The flows have little associated tuffaceous or scoriaceous material and form a series which, though the upper portion has been eroded, is more than 1,100 feet thick. They form the greater bulk of the mountains in the eastern part of the region, lie unconformably upon the diatomite, and lap over the older andesites of Ferguson Butte. They greatly resemble in character the other lavas of eastern Oregon; the olivine basalts are typical gray open-textured rocks, with columnar jointing, and the andesites are dark-blue to gray, fine-textured, almost glassy porphyries with prominent jointing subparallel to the surfaces of the flows.

\section{PLEISTOCENE (?) ROCKS}

Lying on terraces cut in the Pliocene (?) lavas of the Sprague River Valley is an extensive flow of olivine basalt. It is composed of an 
open-textured dark-gray vesicular basalt which under the microscope is seen to be composed of labradorite, augite, and olivine with some magnetite. This flow covers about 30 square miles just northwest of the forks of the Sycan and Sprague Rivers. It is covered with a thin soil layer, but pressure ridges still rise above the soil surface and indicate its recency. A similar flow occurs to the east, on the north fork of the Sprague River, and may be an outlier of this flow. Another flow occurs northeast of the Black Hills, suggesting a connection between all three flows. This interpretation has been given on the map.

\section{RECENT ALLUVIUM}

Swan Lake Valley is almost completely covered by alluvium. Large areas also occur in Alkali Valley, Langell Valley, and Poe Valley and along the Sprague River. There is an interesting locality on the north fork of the Sprague River, where diatomite interbedded with recent alluvium has been exposed by downcutting of the stream.

\section{STRUCTURE}

Block faulting is the dominant structural feature of the Klamath region and has been admirably discussed by Gilbert. ${ }^{32}$ However, there are topographic features in the eastern part of the region which are not grabens or horsts. Portions of Alkali Valley, Poe Valley, and the Sprague River Valley are largely erosional features antedating the present well-marked scarps of the western part of the region. The Sprague River Valley is more than 5 miles wide in its broader portions, and the extensive terraces in the vicinity of Beatty indicate that it was once much wider. The bounding hills are considerably eroded and do not show any evidence of faulting along the margins of the valley. Because the diatomite in this region is overlain, wherever observed, by the upper lava member and underlain by the lower lava member, it is believed that the present areal pattern of the diatomite and associated lake beds is related more to the original irregular deposition of the beds and the post-lava erosion which exposed them than to the block faulting which outlined the Klamath Lake basins.

Minor structural features in this region include folds and faults in the lake-bed series. Excellent exposures of the diatomite and the associated basaltic sand and gravel may be found in the road cuts of the Lakeview Highway in Alkali Valley. Here the beds are folded and faulted on a small scale.

The age of the major structural features of this region, the block faults near Klamath Lake, is related closely to that of the faults to

\footnotetext{
" Gilbert, G. K., Studies of Basin Range structure: U. S. Geol. Survey Prof. Paper 153, pp. $76-84,1928$.
} 
the east, in the Goose Lake, Warner Valley, and Alvord Desert regions. The faulting in the Klamath region is dated by the Pliocene(?) lavas, whose correlatives enter into the structure of the present Cascade Range. The faulting was thus later than the development of the main part of the Cascade Range and probably no older than uppermost Pliocene, and the extreme freshness of some of the scarps, particularly those near Algoma, would indicate a Pleistocene or even Recent age.

\section{DIATOMITE}

The diatomite beds in the Klamath district have been exposed by erosion of the overlying Pliocene (?) lavas. They lie along the lower mountain slopes and on the flats and may be grouped into the six districts described below.

\section{CHILOQUIN}

A large area of diatomite occurs in the vicinity of Chiloquin, close to the main line of the Southern Pacific Railroad. At two localities samples were collected.

Sample 229 came from a bluff on the north side of the Sprague River just east of the settlement known as Bray Mill, in the SW1/4 sec. 19 , T. 34 S., R. 8 E. Here the following section was exposed:

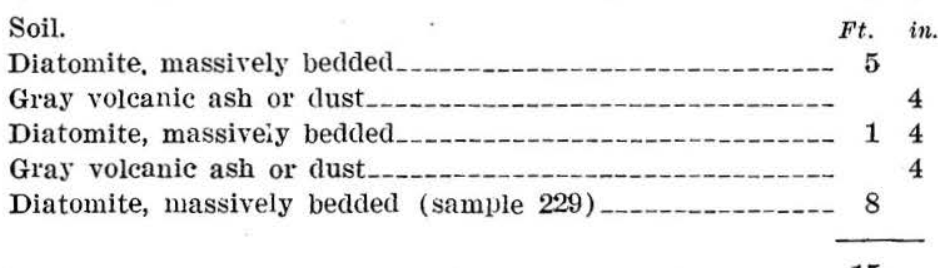

15

The beds $\operatorname{dip} 3^{\circ} \mathrm{W}$. The diatomite is an impure, rather gritty material which is massively bedded and breaks with a subconchoidal fracture. It is of poor quality. Although a large amount of this material is exposed in bluffs along this portion of the Sprague River, it is of no economic importance.

On the grade of the Sprague River road 0.3 mile north of Chiloquin a cut exposes a considerable thickness of diatomite beds, which are regarded as the westward continuation of those exposed near Bray Mill. In the southwest end of the cut basaltic sand and ashy diatomite strike N. $35^{\circ}$ W. and dip $28^{\circ}$ NE. Above these comes nearly 85 feet of diatomite represented by sample 231 . This sample is slightly gritty and of poor quality. In snite of the large amount of material present, it is of no economic interest. 


\section{KIAMATH FAILS}

Diatomite occurs in large amounts in and around the town of Klamath Falls. The railroad and highway cuts north of the town expose considerable thicknesses of material, and the low hill and sagebrush country east of the town is an area of prospective deposits. During the stay of the party in Klamath Falls it was noted that trenches being dug for the installation of the gas pipes were in diatomite. Though the samples collected in this district, which are described below, are not of very good quality, it is possible that prospecting might reveal valuable deposits. A deposit of high-grade diatomite in this vicinity would be insured the advantages of transportation by two large railroads and of an abundance of good labor.

Locality 192 is 1.45 miles south of Klamath Falls on the Ashland highway. The diatomite is exposed in a cut on the west side of the road. The strike, which is parallel to the road, is N. $45^{\circ}$ W., and the dip $17^{\circ} \mathrm{E}$. At the northwest end of the exposure the diatomite rests against a basaltic lava flow, large boulders of which are incorporated in the beds of massive diatomite. A short distance to the south the following section was measured:

Soil.

Ft. in.

Diatomite, massively bedded s.

Coarse volcanic ash, cemented

Diatomite, massively bedded (sample 192)

Volcanic ash, cemented, thickness as much as 1

Diatomite, massively bedded

Volcanic ash, cemented.

The volcanic ash in this section is irregular in thickness. I'le diatomite appears to be of fair quality. No chemical or microscopic examination was made of the sample, but its value is problematic.

Locality 191 is on the Ashland highway 1.6 miles from the Link River bridge in Klamath Falls. A series of diatomite beds is exposed on the east side of the road in a cut. It is 32 feet thick and has three seams of gray volcanic ash or dust near the middle. The beds strike N. $50^{\circ} \mathrm{W}$. and dip $18^{\circ} \mathrm{NE}$. The diatomite is of poor quality. Although large amounts of this material are available, it is of no economic use.

Locality 185 is in a road cut on the east side of the Ashland highway 3.9 miles southwest of Klamath Falls. Here 5 feet of diatomite is exposed under the soil cover. A sample of diatomite collected at this place was found to be of poor quality. This material is of no economic value, though part of a large and extensive deposit.

A rather thick section of diatomite is exposed on the north side of the Ashland highway 4.5 miles southwest of Klamath Falls. It $63952-37-4$ 
occurs as a series of beds which strike N. $25^{\circ}-27^{\circ} \mathrm{W}$. and dip $30^{\circ}-45^{\circ}$ E. A section was paced off, and from the rough measurements made the following thicknesses were calculated:

Soil cover.

Diatomite, massive, thick-beddecl, with a few ashy partings

Coarse yellow volcanic ash

Diatomite, massive, thick-bedded, with a few very thin ash partings (sample 187 from center)

Coarse yellow volcanic ash

Diatomite, massive

Interbedded volcanic ash and diatomite

Diatomite, massive, thick-bedded, with a few thin ash partings

Coarse yellow volcanic ash

Diatomite, massive (sample 186)

Coarse yellow volcanic ash_-_._-_._-_-

Diatomite, massive

Diatomite and volcanic ash, soil-covered__-_-_-_-_-_-_--- 139

Pink volcanic ash__._- 73

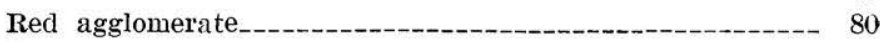

Basalt scoria.

Samples 186 and 187, collected from this section, were of fair quality. An analysis of sample 187 was made in the chemical laboratory of the United States Geological Survey with the following results :

Analysis of diatomite 4.5 miles southwest of Klamath Falls (sample 18\%)

[E. Theodore Erickson, andyst]

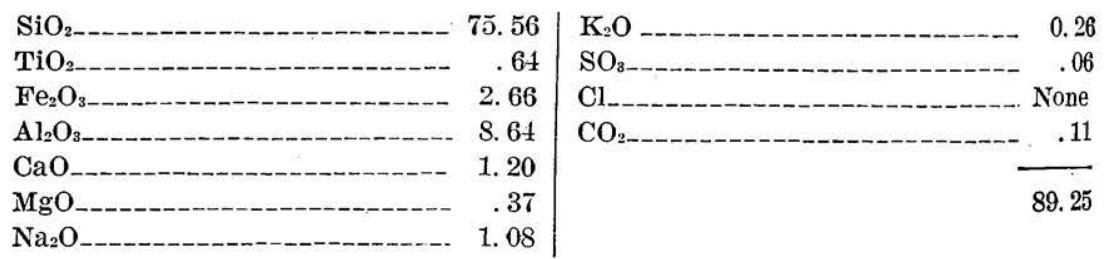

Though this material compares favorably with material from some other localities, it is not of the highest quality.

A portion of this sample was submitted to Kenneth E. Lohman, of the Geological Survey, who reports as follows:

Sample 1014, Klamath Falls, Klamath County, Oreg., sec. 12, T. 18 S., R. 8 E. ; B. N. Moore, no. 187 (pl. 4, E).

This sample contains a fair amount of clay, some volcanic ash, and considerable fine material composed of minute fragments of diatoms. It is largely composed of small flat disks having diameters ranging between 0.015 and 0.110 millimeter. The larger forms are usually broken; the smaller forms 
dre whole. Muny of the liatoms have a "dirty" appearance, due largely to the clay present, which is trapped in the uneven surface of the diatoms.

The principal species of diatoms are as follows:

\begin{abstract}
Stephanodiscus carconensis Grunow. Dominant.
Stephanodiscus astraea (Ehrenberg) Grunow. Abundant.

Stephanodiscus niagarae Ehrenberg. Common.

Cyclotella pygmaea Pantocsek. Common.

Fragilaria construens (Ehrenberg) Grunow. Common.

Cocconeis californica var. menilitica Pantocsek. Common.

Epithemia sorex Kützing. Few.

Navicula radiosa Kützing. Few.

Rhoicosphenia curvata (Kützing) Grunow. Few.
\end{abstract}

There are also 14 other species, most of which occur rarely.

With proper treatment this diatomite might possibly be utilized. In its present state it is suitable for clay-bonded insulating bricks and possibly for insulation material.

Locality 188 is 6.1 miles southwest of Klamath Falls on the Ashland highway. Here diatomite is exposed in two road cuts across narrow spurs. The sample collected was taken from the easterly cut, which showed a face of the earth 7 feet high between road and soil cover and 188 feet long. The bedding of the material was obscured, but it is believed to be essentially flat-lying save for minor wrinkles.

The diatomite from this locality has the lowest apparent density of all the samples collected in the Klamath district and is of good quality. A large tonnage of this earth occurs here, and it is possible that under favorable conditions some use might be made of it for concrete admixture, for insulation, and for insulating brick.

\title{
POE VALLEY
}

Diatomite occurs along the western border of Poe Valley, and in the pass to the south along the road to Malin there are many exposures of material of good quality. In a road cut in the NE1/4 sec. 25 , T. 40 S., R. 11 E., sample 232 was collected. At this point about 50 feet of diatomite is interbedded with nearly flat-lying sediments. It is of fair quality. A chemical analysis was made of this material at the Geological Survey, with the following results:

Analysis of diatomite from sec. $25, T .40$ S., $R .11 \mathrm{E}$.

[F. Theodore Erickson, analyst]

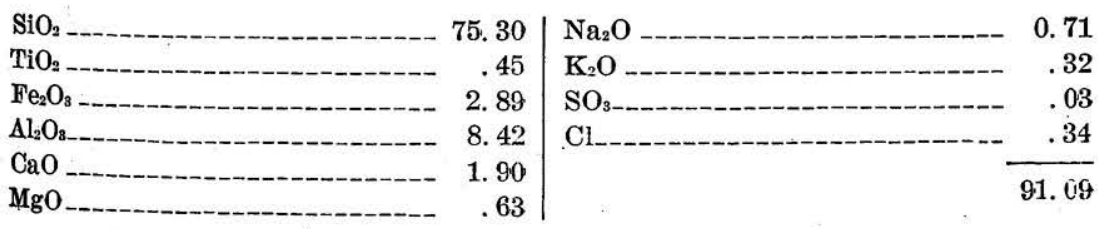


The analysis shows that this diatomite is of a fair degree of purity. A portion of this sample was submitted to Kenneth E. Lohman for microscopic investigation. He reports as follows:

Sample 1017, Poe Valley, Klamath County, Oreg., sec. 25, T. 40 S., R. 11 E.; B. N. Moore, no. 232 (pl. $4, F)$.

Some organic matter is present in this sample, as well as clay and voleanic glass, aggregating between 5 and 10 percent. Most of the diatoms present have maximum dimensions under 0.050 millimeter, and fully 25 percent are under 0.010 millimeter. Approximately 8 to 10 percent have maximum dimensions of 0.180 millimeter, with sponge spicules frequently attaining 0.3 millimeter in length. Over 40 percent of the diatoms are broken, the distribution of the sizes of the fragments being 50 percent below 0.05 millimeter, 25 percent below 0.02 millimeter, and 25 percent below 0.004 millimeter. The diatoms are fairly clean, although considerable dirt is present in the matrix.

The principal species of diatoms are as follows:

Melosira granulata (Ehrenberg) Ralfs. Dominant.

Melosira distans Kützing. Abundant.

Cyclotella operculata Kützing. Common.

Amphora ovalis Kützing. Few.

Cocconeis pediculus Ehrenberg. Few.

Cymbella cistula var. maculata Grunow. Few.

Cymbella mexicana Ehrenberg. Few.

Epithemia sorex Kützing. Few.

Epithemia westermanni Kützing. Few.

Melosira solida Eulenstein. Few.

Navicula radiosa Kützing. Few.

Rhopolodia gibba (Kützing) Müller. Few.

Total number of species, 28.

This material might possibly be utilized under favorable conditions for such purposes as clay-bonded bricks, for insulation, and even for concrete admixture, for which the volcanic dust is not disadvantageous. However, in spite of the large tonnage here available, this deposit is regarded as of no present economic value.

\section{SPRAGUE RIVER DISTRICT}

Large amounts of diatomite occur in the eastern part of the Klamath district, in the broad valley of the Sprague River. These deposits are of the same age as those around Klamath Falls, their exposure being due to the erosion of the overlying lavas. This region is served by the Oregon, California \& Eastern Railway which carries all the traffic of the lumber industry in the Sprague River region. Transportation can also be had by motor vehicle over the excellently conditioned Klamath Falls-Lakeview Highway and its connecting roads.

BEATTY

Half a mile west of the town of Beatty on the Lakeview Highway, road cuts reveal diatomite bads which underlie much of this region. 
Exposures are few in these grassy regions, and only two were noted.

Locality 213 is half a mile west of the town of Beatty on the Lakeview Highway, in a road cut. Here the following section was exposed:

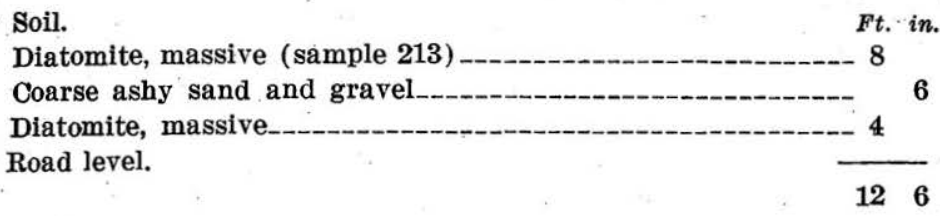

The beds strike N. $35^{\circ} \mathrm{W}$. and $\operatorname{dip} 3^{\circ} \mathrm{W}$.

Sample 213 is a rather impure, gritty material. It is of fair or poor quality. Although large tonnages might be developed here, the deposit is regarded as of no present economic interest.

A quarter of a mile west of Beatty on the Lakeview Highway, another cut reveals nearly 7 feet of slightly contorted though essentially flat-lying diatomite overlain by 16 inches of ashy diatomite and that in turn by 5 feet of coarse agglomeratic volcanic ash. Sample 214, collected here, is a rather impure, gritty diatomite of poor quality. Large tonnages are available here, but it is believed that this deposit is of no economic importance.

NORTH FORK OF SPRAGUE RIVER

A very interesting occurrence of diatomite is that in the alluvium of the low banks along the North Fork of the Sprague River. The following section was measured about 50 feet west of the road crossing in the east bank:

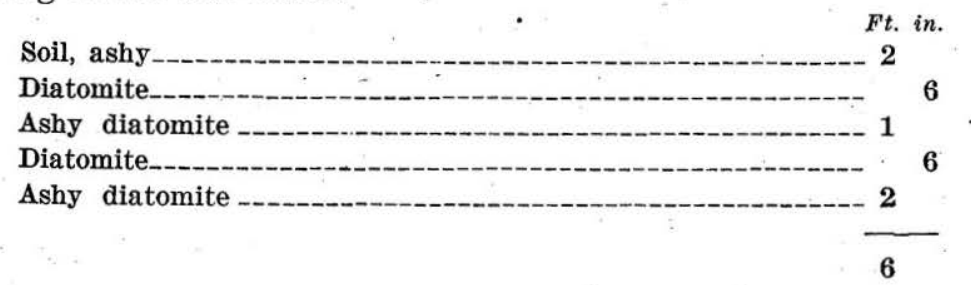

The diatomite is corky in appearance and contains much organic matter, most of which has rotted away leaving a porous open structure. The earth is of Recent age and is of the same age as the soil that forms the flats in this region. It is probably a deposit in an old lake or marsh formed by some temporary obstruction in the river channel. It is, of course, much younger than the other diatomite deposits just described but is of interest because it illustrates the mode of formation of some diatomite deposits. 


\section{PLATE 6}

A. Sample 222 collected in alluvium on North Fork of Sprague River, Klamath County.

1. Fragilaria brevistriata Grunow.

2. Melosira ambigua (Grunow) Müller.

3. Melosira crenulata var. laevis (Ehrenberg) Grunow.

$B$. Sample 227 collected near town of Sprague River, Klamath County.

1. Stephanodiscus carconensis Grunow.

2. Melosira solida Eulenstein.

C. Sample 301 from deposit on Indian Creek near Elgin, Union County.

1. Cymbella cistula (Hemprich) Kirchner.

2. Fragilaria brevistriata Grunow.

$D$. Sample 5 from Clover Creek, Baker County.

1. Cymbella cistula (Hemprich) Kirchner.

2. Melosira distans Kützing.

E. Sample 26 from locality near Durkee, Baker County.

1. Coscinodiscus cf. C. payeri Grunow.

2. Coscinodiscus cf. $C$. elegans Greville var.

$F$. Sample 7 from locality near Austin, Grant County.

1. Melosira granulata (Ehrenberg) Ralfs.

2. Melosira granulata var. curvata Grunow. 

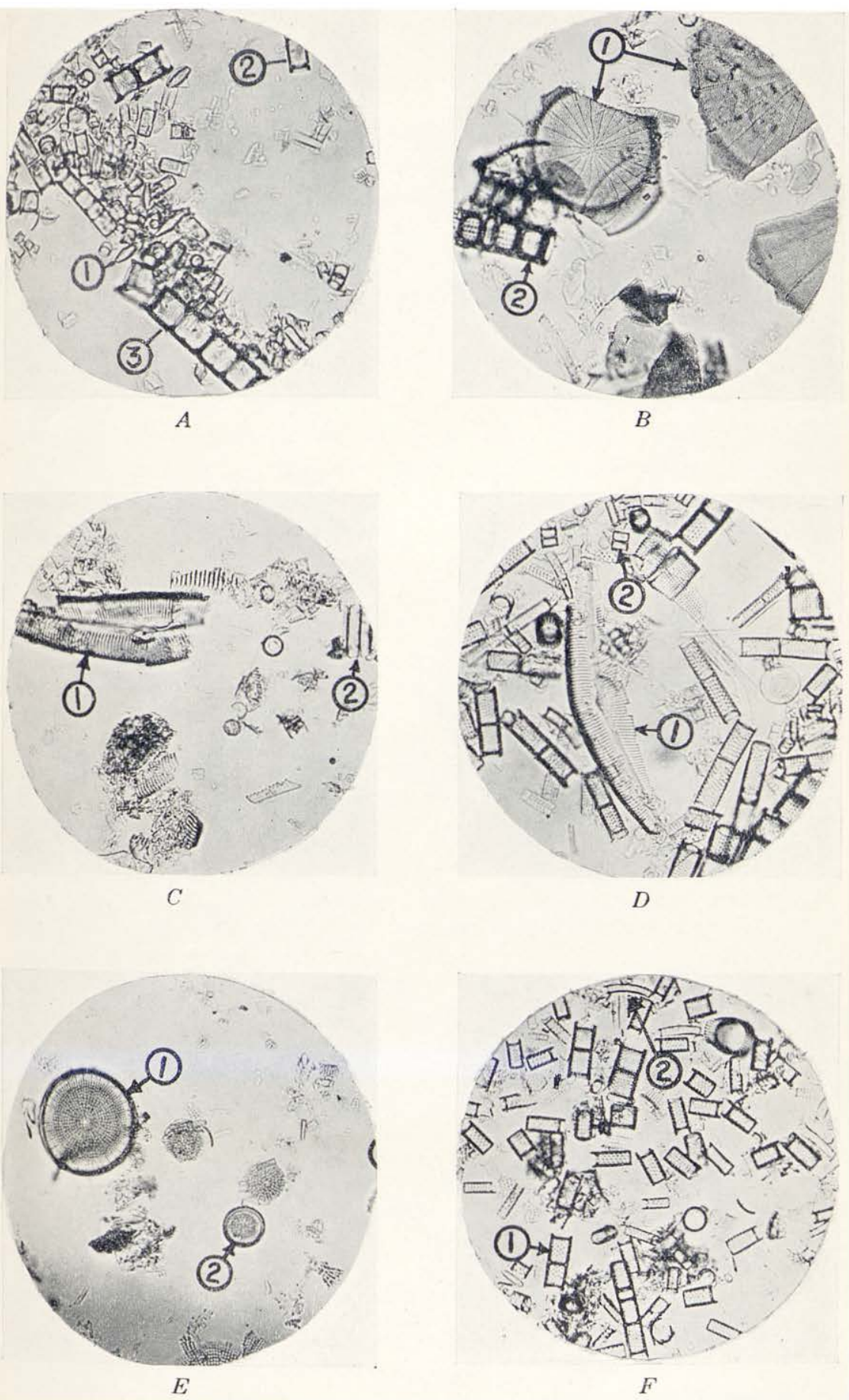

PHOTOMICROGRAPHS OF STREWN MOUNTS OF UNCLEANED DIATOMITE OF EASTERN OREGON.

Enlarged 300 diameters. Photographed by K. E. Lohman. 
Sample 222, from this deposit, is a discolored material resembling cork in appearance. A chemical analysis of this material was made in the Geological Survey laboratory, with the following results:

Analysis of diatomite from sec. 5, T. 36 S., R. 14 E.

[F. Theodore Erickson, analyst]

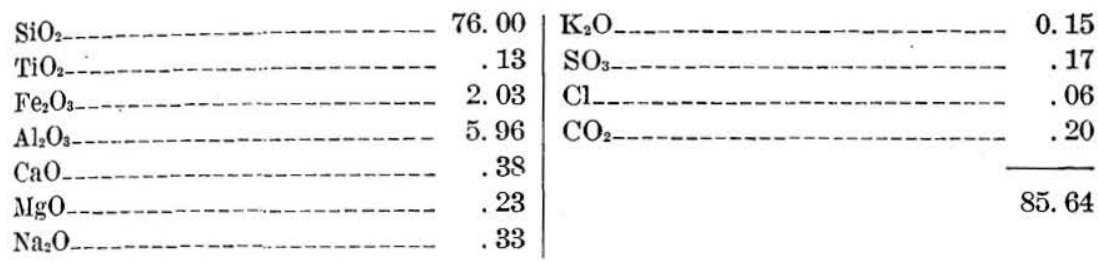

Though this material is not as pure as the low apparent density would appear to indicate, its purity is comparable to that of a number of diatomites now on the market. The small amount present, however, renders it commercially useless.

A portion of sample 222 was submitted to Kenneth E. Lohman for microscopic determination, and his report follows:

Sample 1015, North Fork of Sprague River, Klamath County, Oreg., sec. 5, T. 36 S., R. 14 E. ; B. N. Moore, no. 222 (pl. 6, $\Lambda$ ).

Although of a distinctly gray color in the hand specimen, this material is apparently rery low in impurities when examined under the microscope. The gray color may be due to small amounts of rather dark organic matter, which would easily come out on calcining. The size of the diatoms varies greatly in this sample, from a maximum of 0.255 millimeter to a minimum of 0.006 millimeter; 90 percent have a maximum dimension smaller than 0.10 millimeter, 75 percent smaller than 0.05 millimeter, and 50 percent smaller than 0.02 millimeter. The most common species has an average diameter of 0.008 millimeter, and a length of 0.010 to 0.064 millimeter, depending on the number of complete frustules remaining attached. The breakage is slight, whole diatoms making up fully 75 percent of the material. The diatoms are fairly clean.

The principal species of diatoms are the following:

Melosira ambigua (Grunow) Müller. Dominant.

Melosira crenulata var. laevis (Ehrenberg) Grunow. Abundant.

Melosira distans Kützing. Common.

Epithemia turgida (Ehrenberg) Kützing. Common.

Fragilaria brevistriata Grunow. Common.

Fragilaria construens (Ehrenberg) Grunow. Common.

Pinnularia nobilis Ehrenberg. Common.

Stauroneis phoenicenteron Ehrenberg. Common.

Total number of species, 28.

TOWN OF SPRAGUE RIVER

Diatomite of a type that occurs at other points in the Sprague River Valley is well exposed in the bluff north of the town of Sprague River. Road cuts in this bluff show nearly 105 feet of diatomite in massive beds from 5 to 15 feet thick. Volcanic ash is 
present in minor amounts and forms thin partings. The bluff is covered by a recent flow of olivine basalt.

Sample 226 was taken at the base of the series. The sample was slightly gritty and of fair or poor quality. Sample 227 came from the top of the series, 0.3 mile up the road from sample 226. It was harsh in feel and of poor quality. A chemical analysis of this sample was made in the Geological Survey laboratory, with the following results:

Analysis of diatomite north of town of Sprague River (sample 297)

[E. Theodore Erickson, analyst]

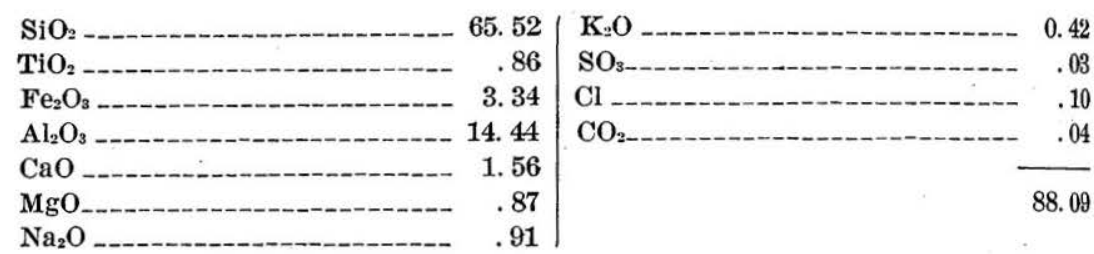

The analysis shows this material to be an impure diatomite.

A portion of this sample was submitted to Kenneth E. Lohman for microscopic analysis. He reports as follows:

Sample 1016, Sprague River, Klamath County, Oreg., sec. 12, T. 36 S., R. 10 E. ; B. N. Moore, no. 227 (pl. 6, $B$ ).

This sample contains as much as 10 percent of impurities, principally clay and volcanic glass. Two species of diatoms, differing greatly in size, dominate in about equal amounts. The larger one (Stephanodiscus carconensis) has an average diameter of 0.120 millimeter; the smaller one (Melosira solida), 0.015 millimeter. The large forms are fragile, and nearly all are broken; the small ones are, as their specific name implies, strong and seldom broken. In spite of the presence of small amounts of clay, the diatoms are fairly clean.

The principal species of diatoms are listed below:

Stephanodiscus carconensis Grunow. Abundant.

Melosira solida Eulenstein. Abundant.

Cyclotella compta (Ehrenberg) Küitzing. Few.

Diploneis elliptica (Kützing) Cleve. Few.

Fragilaria brevistriata Grunow. Few.

Stephanodiscus astraea (Ehrenberg) Grunow. Few.

In addition 15 other species of diatoms occur in small numbers.

This material might perhaps be used for clay-bonded bricks. It is possible that the natural earth contains sufficient clay for this purpose without mixing with other material. For other uses special processing is required. For this reason the deposit, in spite of its size and proximity to the railroad, is considered to be of no present economic value. 
Extensive deposits of diatomite occur in Alkali Valley, the floor of which is a gently rolling sagebrush plain. Except where the Lakeview Highway crosses the long swells in cuts no exposures are available. In general the diatomite and associated clay, sand, and gravel beds are considerably folded and even crumpled.

Sample 208 was collected from a road cut on the Lakeview Highway about 0.1 mile west of Dairy. The diatomite here is practically flat-lying and composed of hard, tough material with no ash or clay beds. A thickness of 7 feet is exposed. The diatomite is impure and harsh to the feel and otherwise of poor quality. A large amount of this earth is available, but the deposit is considered to be of no commercial value.

On the Lakeview Highway 1.5 miles east of Dairy 8 feet of diatomite is exposed in a road cut. The beds are considerably distorted but in a broad way may be considered to lie nearly flat. Sample 209 , from this locality, is an impure earth. In view of the obviously low quality of this sample, the deposit is considered of no economic value save possibly as a source of material for clay-bonded brick.

Diatomite was observed in a road cut 2 miles east of Dairy on the Lakeview Highway, where 7 feet of impure material was exposed, overlain by coarse basaltic sand and gravel. Farther east other road cuts revealed thin beds of diatomite, basaltic sand, and basaltic gravel, more or less crumpled but dipping steeply to the northeast. Sample 210, taken at this locality, is an impure diatomite rather gritty and otherwise of poor quality. Although a large tonnage of material occurs here, it is believed to be of no present economic interest.

\section{OLENE DISTRICT}

The deposits of the Olene district lie along the Lost River between the Klamath Falls district, to the west, and Swan Lake Valley, to the east. These deposits occur close to the level of the river and are overlain by great thicknesses of basaltic lavas, which form the mountains to the north and south. The deposits possess the advantage of location along the line of the Oregon, California \& Eastern Railway.

Locality 199 (see pl. 5) is on the south side of the Lost River 0.30 to 0.35 mile west of the Poe Valley market-road bridge across the river. Here a road cut exposes a diatomite of low quality, massively bedded, with no partings of clay or volcanic ash. The height as exposed by the cut is 12 feet and the length 250 feet. Sample 199 on examination is seen to be a rather gritty dark earth of obviously low grade. This diatomite is of no economic importance.

About 0.1 mile east of locality 199, on the south side of a road cut, is an exposure of diatomite 5 feet high. The attitude of the beds cannot be made out. A sample collected here (198) is of poor quality. 
The obvious impurity of this material as shown by its weight and grittiness renders it of no economic value at the present time.

On the north side of the Lost River in a railroad cut about 0.15 mile east of the Poe Valley market-road bridge is an exposure of diatomite about 15 feet thick. It is slightly crumpled, but in a broad way is nearly flat-lying. It is overlain unconformably by the basaltic flows which make up the main mass of the mountain to the north. This material, as shown by sample 200, is rather gritty and of very poor quality. Its weight and grittiness make it of no economic value, despite its location on the railroad right-of-way.

About 0.1 mile east of locality 200, between the top of a railroad cut and the level of the Lakeview Highway, 45 feet of massively bedded diatomite with thin volcanic-ash partings is exposed. Sample 201 was collected in the south wall of the railroad cut. It is a white earth, rather gritty, and of poor quality. Sample 202 was collected 100 feet to the south in the bank along the highway and is likewise of poor quality. Neither one of these samples is of sufficiently high grade to warrant development of this deposit, despite its favorable location and its size.

About 0.1 mile east of localities 201 and 202, about 10 feet of diatomite and interbedded seams of volcanic ash is exposed in a railroad cut. The diatomite is essentially flat-lying, though wrinkled, and is exposed for a distance of 300 feet. Sample 203, from this locality, proved to be of poor quality, and so this deposit is considered to be of no economic value.

About 1.25 miles east of the Poe Valley market-road bridge on the north side of the Lost River in a cut on the north side of the Lakeview Highway 12 feet of fractured massively bedded diatomite occurs. From this material sample 204 was collected. Above this cut is a flume, the cut for which exposes horizontally bedded unconsolidated sand and gravel resting with marked angular unconformity upon the diatomite. Above the gravel is a 6-foot bed of diatomite from which sample 205 was collected. Neither of these samples is of high grade, and it is believed that this deposit is of no economic importance.

Locality 206 is 2.5 miles east of the Poe Valley market-road bridge on the Lakeview Highway in a cut on the east side of the road. Here 6 feet of diatomite is exposed, from which sample 206 was collected. Its low quality renders this deposit of no economic importance.

\section{CONCLUSIONS}

The diatomite deposits of the Klamath district are quite different from those of Terrebonne, Harper, or the Otis Basin. The flora of the Klamath deposits is distinctly different from those of the other deposits. A detailed scientific discussion of the floras is not 
appropriate here, but Kenneth E. Lohman is preparing a paper on these floras for separate publication.

The quality of the Klamath diatomite, according to accepted standards, is in general poor. A great field, however, is open for the utilization of much of this material for clay-bonded insulating bricks and forms if a sufficiently large market should be found for the products. In many localities the diatomite contains enough clay to be burned without the addition of other clay. Another possible use is burning the material in pellets to furnish a light-weight aggregate similar to the light-weight shale aggregates used in concrete construction in some of the Eastern States. For use as a concrete admixture there is probably no material sufficiently pure, and the same may be said of material for filtration and insulation. Volcanic dust constitutes the principal impurity of this diatomite, and volcanic dust itself is used in cement admixtures just as diatomite is. If this value were recognized in considering uses for diatomite, the arbitrary specifications for cement admixture might possibly be waived without harmful results.

Huge tomnages of low-grade material are available in this region. No estimate can be given, but it would be many times the amount present in the other large districts of Oregon. It is believed that, should it ever be desirable to develop resources of diatomite in Klamath County, the best area to investigate is that around the town of Klamath Falls.

\section{INDIAN CREEK DIATOMITE}

\section{LOCATION}

A deposit of diatomite occurs in the Indian Creek Valley south of Elgin, Union County, in the northeastern part of the State. This deposit has been noted by Mitchell ${ }^{33}$ but has not been described. I visited the locality in 1931 in company with Mr. E. H. Horn, of Elgin.

This deposit lies in the broad lower valley of Indian Creek, a tributary of the Grande Ronde River, here nearly a mile wide. The valley floor is not flat but rolling and is cut by numerous small streamlets into low knolls and mounds. Along the hillsides bordering the valley there is a definite break between the gently rolling forms of the valley bottom and the cliffs marking the adjacent flat-topped hills.

The deposit is only $41 / 2$ miles from Elgin, where there are facilities for shipping by the Union Pacific System. Half the distance to Elgin is covered by a well-graveled market road, and the rest by an oiled highway.

\footnotetext{
${ }^{33}$ Mitchell, G. J., Minerals of Oregon : Oregon Univ. Bull., new ser., vol. 13, no. 3, p. 23,
1915.
} 


\section{GEOLOGY}

The oldest rocks at the deposit are yellow tuffs, fine-grained, thinbedded, and well consolidated, belonging to the general group of Miocene or Pliocene lake beds. At other places in the region these tuffs overlie a thick series of andesitic and basaltic lavas, known as the Columbia River lava and are overlain by several lava flows.

The structure of this deposit appears to be that of a series of nearly horizontal beds, so far as can be told by the attitude of the overlying lavas. As only one outcrop of the diatomite was located, no idea can be given of the exact extent of the bed other than that as it is essentially flat it should occur in many of the low mounds in the valley.

\section{DIATOMITE}

The sample of diatomite here described was obtained on the east bank of a dry creek bed just west of a group of prominent pine trees a little southwest of the center of sec. 1, T. 1 S., R. 39 E. Here the lowest beds exposed were 4 feet of yellow tuff covered with 7 feet of diatomite, ashy at the base, and overlain by several feet of soil. The valley bottom has a thick cover of soil that effectually conceals the diatomite, so that it can be traced only by digging or by auger.

The Indian Creek diatomite is massively bedded and shows no signs of lamination. It is very tough and of high density. Kenneth $\mathrm{E}$. Lohman has examined a portion of the sample and reports as follows:

Sample 1034, Indian Creek, Union County, Oreg., sec. 1, T. 1 S., R. 39 E.; B. N. Moore, no. 301 (pl. 6, $C$ ).

This sample contains a considerable quantity of clav, volcanic ash, and also apparently some organic matter. There is a great range in sizes of diatoms, from a maximum of 0.13 millimeter to a minimum of 0.004 millimeter, with a fairly uniform distribution between these two extremes. Fully 80 percent of the diatoms are broken, many of the smaller fragments contributing to the fines. The diatoms are dirty, many of them so much so as to make the markings difficult to see.

The principal species of diatoms are these:

Cynbella cistula (Hemprich) Kirchner. Abundant.

Cymbella ehrenbergii Kützing. Abundant.

Cymbella lanceolata Ehrenberg. Common.

Fragilaria brevistriata Grunow. Common.

Fragilaria construens (Ehrenberg) Grunow. Common.

Fragilaria pinnata Ehrenberg. Common.

Fragilaria virescens Ralfs. Common.

Melosira italica Kützing. Common.

Pinnularia appendiculata Kützing. Common.

Pinnularia major Kützing. Common.

Navicula radiosa Kützing. Common.

Synedra rumpens Kützing. Common.

Total number of species found, 49.

Because of impurities this material has but little value unless for use in clay-bonded diatomite brick or other similar products. 


\section{CLOVER CREEK DISTRICT}

\section{LOCATION AND FIELD WORK}

The Clover Creek diatomite district is situated on Clover Creek in the Powder River Valley about 20 miles east of Baker. The deposits of diatomite occur in lake beds, which crop out extensively in T. 8 S., Rs. 42 and 43 E.

R. W. Richards and I spent several days in this district in 1930 in the course of the general reconnaissance of the nonmetallic mineral deposits of eastern Oregon. James Gilluly, of the United States Geological Survey, who was mapping the Baker quadrangle, directed our attention to this deposit, and to him is due credit for information on the general geology of the district. Mr. W. D. Pierce, of Baker, furnished information concerning the claims held by him and his associates in this district.

\section{GENERAL FEATURES}

This district embraces an elliptical area 12 miles long and 7 miles wide, of lake beds along the southeasterly course of the Powder River in the neighborhood of Keating. The deposits occur in low rolling hills and old river terraces, which to the north, south, and east are bounded by higher mountains.

\section{GEOLOGY}

\section{STRATIGRAPHY}

The rocks in this district inclucle an old greenstone series of Permian age and a late Tertiary series. According to Gilluly ${ }^{34}$ the greenstones are representatives of old Permian lavas, closely folded, sheared, and altered. Resting unconformably on these rocks is a series of lake beds with interbedded lavas. Along the north edge of the district the diatomite beds of this series lap over onto the greenstones, but elsewhere fine-grained, olive-yellow tuffs may be found which normally underlie the diatomite. With the tuffs are associated locally beds of clay, gravel, coal, and diatomite. Interbedded with the series are several lava flows that may be related to the underlying Columbia River lava, which is not exposed in this district.

Save for thin veneers of terrace gravel, no other rocks are present in the district. The soil cover is very thin, nowhere more than 2 feet thick, but though it offers no obstacle to mining, its persistence makes prospecting difficult except by digging.

\section{STRUCTURE}

This deposit has a basinlike structure. The rocks north of the Powder River dip toward the stream at angles of about $5^{\circ}$, and those

${ }^{34}$ Gilluly, James, Copper deposits near Keating, Oreg. : U. S. Geol. Survey Bull. 830, pp. 6-8, 1933. 
to the south dip northeast at similar angles. In the northern part of the district the diatomite is well exposed at certain places but not enough to reveal details of the structure. The deposit is free of small wrinkles or contorted strata.

\section{DIATOMITE \\ OCCURRENCE}

Diatomite occurs over large areas in this district. It is best displayed north of the Powder River, where outcrops exposing from 5 to 25 feet of diatomite occur along some of the creeks and in road cuts. The hills, which are covered with just enough soil to hide the rocks effectually, are apparently all diatomite and tuff, the low dips carrying the beds to the southwest at nearly the slope of the land. Southwest of the river there is a narrow band of diatomite, but southwest of that the tuffs and interbedded lava flows predominate.

The area underlain by diatomite in this deposit is estimated at 25 square miles.

\section{QUALITY}

Only a few specimens of diatomite were collected from this deposit. Specimen 1 was taken from a prospect hole in the northeast corner of the NW1/4 sec. 10 , T. 8 S., R. 42 E. The color and weight show it to be of no economic value.

Specimen 2 was taken from a face in a short trench in the northwest corner of the $\mathrm{NE} 1 / 4$ sec. 10 , T. 8 S., R. $42 \mathrm{E}$. This is a fine, massive diatomite, fairly tough, smooth to the feel. The thickness here exposed was 5 feet. It is of fair quality.

Specimen 5 was taken from the $\mathrm{SW}_{1 / 4} \mathrm{NW}^{1 / 4}$ sec. 11 , T. $8 \mathrm{~S}$., R. $42 \mathrm{E}$. Here a face has been cleared just south of the road and across the creek, exposing about 15 feet of diatomite. A drift has been run 53 feet S. $36^{\circ}$ E. into the hill, and about 26 feet from the mouth a winze 12 feet deep has been sunk. The following section in and about the opening was measured:

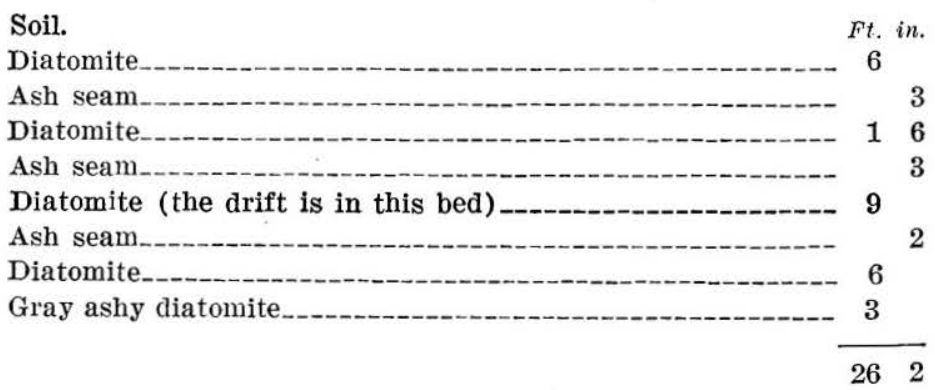

Both color and weight of the diatomite show it to be of good quality. An unfavorable feature of this otherwise high-grade diatomite is the occurrence in it of many small pebbles or bombs of 
basaltic material. These have been greatly altered, so that they appear as hard yellowish-green clayey lumps whose original nature is not exactly determinable because of the alteration. These lumps are distributed throughout the mass at the rate of about one to the cubic foot.

An analysis of the diatomite gave the following results:

Analysis of diatomite from sec. 11, T. \& S., R. $12 \mathrm{E}$.

[\%. Theodore Erickson, anxlyst]

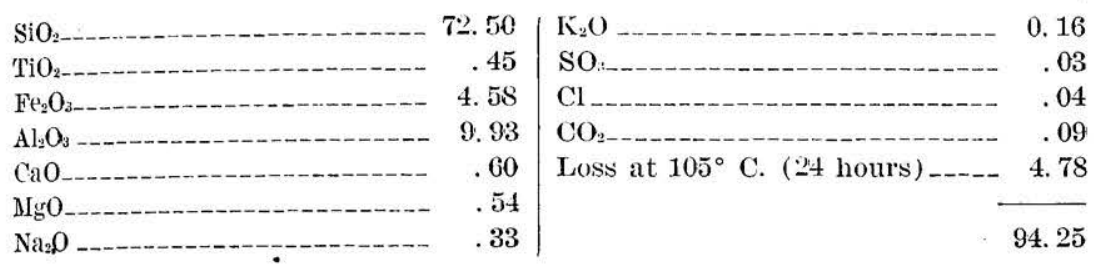

The high percentages of $\mathrm{Fe}_{2} \mathrm{O}_{3}$ and $\mathrm{Al}_{2} \mathrm{O}_{3}$ suggest that perhaps there are more small lumps of the basaltic material mentioned scattered through the earth than are apparent to the eye.

A portion of the sample analyzed was submitted to Kenneth E. Lohman, of the United States Geological Survey, who furnished the following report :

Sample 1013, Clover Creek district, Baker County, Oreg., sec. 11, T. 8 S., R. 42 E.; B. N. Moore, no. 5 (pl, $6, D$ ).

This material is rery pure, the principal visible impurities being clay, rolcanic glass, and "fines" composerl of finely broken diatom fragments. It is of fairly uniform size. Over 90 percent of the diatoms have maximum dimensions under 0.025 millimeter, and the largest diatoms present have a maximum dimension of 0.124 millimeter. The fines are low, owing largely to the fact that over 85 percent of the diatoms present are whole. This low breakage is due to the smallness and high mechanical strength of the dominant species.

The principal species of diatoms are as follows:

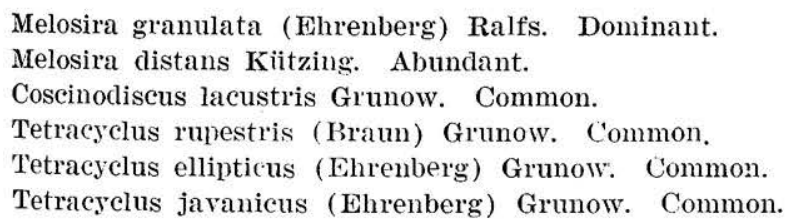

In addition to the above, there are 26 species of diatoms, most of which occur more rarely. All the diatoms are fairly clean.

Specimen 51 was collected from a road cut in the center of the NW $1 / 4$ sec. 29 , T. 8 S., R. 43 E. Here $4 \frac{1}{2}$ feet of a light-colored laminated diatomite was exposed. The color and weight of this material show it to be of little value. It extends under a hill to the west, and a greater thickness is present there than is indicated in the road cut.

The diatomite represented by sample 5 is the best material noted in this district. Although the microscopic examination indicates a 
high degree of purity, small amounts of basaltic pyroclastic rocks are present and furnish rather large percentages of iron and alumina. This material is not suitable for some of the more exacting applica. tions of unmilled diatomite, but milling might possibly remove the objectionable foreign matter and furnish a high-grade product.

This district has not been examined in detail, and it is very probable that in other places the diatomite beds may be of higher quality.

\section{MINING CONDITIONS}

The conditions in this district are favorable to the mining of diatomite. The beds dip very gently, folds and faults of any magnitude are not common, and the overburden is thin. The occurrence of the material on low hills with 1 to 2 feet of soil suggests that open-cut mining or quarrying could be carried on very cheaply. The diatomite could be removed in a series of benches following the partings between the different beds. The earth is fairly dry, and in the summer air-drying should be sufficient to prepare the earth for milling.

Though this district is about 25 miles from both Baker and Robinette, there is a branch line at Medical Springs, 10 miles east. It is connected with these places by excellent roads.

\section{DEVELOPMENT}

The only attempt to exploit this district has been made by a group composed of W. D. Pierce, T. B. Perkins, C. W. Masters, and A. Rodmar, of Baker, and W. S. Levens, of Salem. This group owns a patented claim consisting of the W1/2 SW1/4 sec. 2 and the $\mathrm{W}^{1} / 2 \mathrm{NW}^{1} / 4$ sec. 11 , T. 8 S., R. 42 E. An adjoining unpatented claim consists of the NE1/4 sec. 10, and another one of the E1/4 NW1/4 and the $\mathrm{SE} 1 / 4 \mathrm{SW} 1 / 4$ sec. 11. Sample 5, just described, was taken from the drift on the last-mentioned property. The combined claims cover 440 acres, and if the thickness of the minable diatomite is reckoned at 9 feet, the extent of the bed at 220 acres, and the weight at 30 pounds per cubic foot, a conservative estimate of about $1,000,000$ long tons is obtained.

\section{RICHLAND DIATOMITE}

\section{LOCATION}

The Richland diatomite deposit is near the town of Richland, on the Powder River a few miles above its junction with the Snake. It consists of a roughly trapezoidal area, occupying most of T. 9 S., R. 45 E., and a small part of T. 9 S., R. 46 E.-essentially what is known as Eagle Valley. A few samples of diatomite were collected here by R. W. Richards and me during the season of 1930, and the following report is based on that visit. 
The district is a small basin of lake beds bounded on the north, south, and east by mountains. On all sides are terraces of the Powder River and Eagle Creek at altitudes of 2,100 to nearly 3,500 feet. The lower terraces are well preserved but the upper ones are considerably dissected. The nearest railroad is the Robinette branch of the Oregon Short Line at Robinette, on the Snake River some 7 miles by a gravel road from Richland.

\section{GEOLOGY}

The rocks on which the sediments in the Richland district lie belong to the series of basalt and hypersthene andesite flows of the Columbia River. A series of lake-bed sediments which are believerl to be the equivalent of the Payette formation of southeastern Oregon rest on these lavas. These sediments are composed of fine bedded yellow tuff, ash, gravel, and diatomite. Near the top of the section is an extensive flow of pumiceous rhyolite. Resting on the rocks of the lake-bed series are terrace deposits of different ages. In the northwestern part of the area these reach thicknesses of 50 to 100 feet. The alluvium is thin, and most of the surface is covered with only a thin mantle of soil.

This deposit occupies a basin, the sediments dipping toward the center from the periphery. The diatomite is free of wrinkling or contortion.

\section{DIATOMITE}

Diatomite occurs at several localities in the southeastern part of this district north of the Powder River. The sediments south of the river appear to be mainly tuff and ash. On the road to Sparta no outcrops of diatomite were observed. The distribution of the diatomite suggests that it was deposited in this region and then covered by younger sediments which overlapped onto the Columbia River lava. Subsequent folding and erosion of the basin thus formed have given the present pattern to the diatomite area.

Two samples of diatomite were collected. Sample 19 was taken from beds near the center of the SW1/4 sec. 19 , T. 9 S., R. 46 E. The diatomite is massively bedded but of poor quality, as shown by its color and weight. In the outcrop a thickness of 5 feet was exposed, but if the slumping is taken into account a true thickness of nearly 25 feet may be considered to be present.

Sample 20 was collected in the NE1/4 sec. 25 , T. 9 S., R. 45 E. It tends to be rather gritty and otherwise of poor quality. This sample was taken from the cliff along the north terrace of the Powder River, where about 40 feet of diatomite is capped by about 25 feet of tuffs and other lake beds.

$63952-37-5$ 
The diatomite of this district is not of high quality and in view of its distance from markets probably has little value. There is more than 2,000,000 tons of material here suitable for use in clay-bonded diatomite bricks, etc., should local users ever need it.

\section{DIATOMITE NEAR DURKEE}

Diatomite deposits of fair size occur near Durkee, Baker County, in lake-bed sediments that can be traced south from the Clover Creek region. These beds are of about the age of the Mascall formation (generally considered to be middle Miocene). They rest on the Columbia River lava, which here, together with the overlying sediments, forms the southern flank of the anticline represented by Little Lookout Mountain. Faults are common in this region, and the complex pattern produced by the different blocks prevents the easy prospecting of the diatomite beds. Only two localities of diat. omite were noted, though there may be many more.

\section{SWAYZE CREEK}

Diatomite occurs in the low hills near the mouth of Swayze Creek just north of the Oregon Trail, only a few hundred feet from the main line of the Union Pacific Railroad. In the SE1/4 sec. 34, T. 11 S., R. 43 E., massively bedded material 50 feet in total thickness was noted. Sample 30 showed from color and weight that this material is of no commercial importance unless it can be used in making clay-bonded diatomite products.

\section{MANNING CREEK}

The deposit on Manning Creek occurs in lake-bed sediments exposed on the east side of the Lookout Mountain road in the SE1/4 sec. 13, T. 11 S., R. 43 E. Here nearly 55 feet of generally flat-lying beds of diatomite and associated tuffs and thin ash beds are exposed. The diatomite (sample 26), as shown by color and weight, is of low grade and of no importance because it is so far from the railroad.

Kenneth E. Lohman reports that the diatom flora of this material indicates deposition in brackish water, unlike the deposit on Clover Creek, which is regarded as nearly the equivalent of these beds stratigraphically and was deposited in fresh water. His detailed report follows.

Sample 1030, Durkee, Baker County, Oreg., sec. 13, T. 11 S., 43 E.; B. N. Moore, no. 26 (pl. 6, E).

Volcanic ash and clay constitute the only visible impurities in this sample. The range of sizes of the diatoms is considerable, from a maximum of 0.06 millimeter to a minimum of 0.006 millimeter; 75 percent have maximum dimensions between 0.03 and 0.06 millimeter and 25 percent between 0.03 and 
0.006 millimeter. Owing to the fact that about 40 percent of the diatoms are fractured, however, the distribution of fragments is somewhat different-50 percent between 0.06 and 0.03 millimeter, 25 percent between 0.03 and 0.01 millimeter, and 25 percent below 0.01 millimeter. The diatoms are fairly clean.

The principal species of diatoms are as follows:

Coscinodiscus cf. C. elegans Greville var. Abundant.

Coscinodiscus ef. C. payeri Grunow. Common.

Coscinodiscus $2 \mathrm{sp}$. Common.

Fragilaria brevistriata Grunow. Few.

Tetracyclus rupestris (Brun) Grunow. Few.

Achnanthes lanceolata Brebisson. Rare.

Gomphonema semiapertum Grunow. Rare.

Melosira distans Kützing. Rare.

Melosira arenaria Moore. Rare.

Fragilaria pinnata Ehrenberg. Rare.

\section{AUSTIN DIATOMITE}

\section{LOCATION AND GENERAL FEATURES}

The Austin diatomite deposit is on the west slope of the Blue Mountains, in the east-central part of Grant County. This deposit has been mentioned by Pardee and Hewett ${ }^{35}$, and its flora has been studied by Chaney ${ }^{36}$, who has investigated the fossil floras of Oregon.

The present report is based on a brief visit paid to this locality by R. W. Richards and me in the summer of 1930 .

This district lies on the headwaters of the middle fork of the John Day River, on the west slopes of the Blue Mountains. The topography of the region as a whole is rugged, but around Austin, a small logging settlement, the country is rather rolling. The extent of the deposit is not known, because, except in a railroad cut, no exposures are to be seen.

The deposit is on the line of the Sumpter Valley Railroad, a narrow-gage line connecting Baker with Prairie City and serving the lumber interests in the Blue Mountains. Transportation by this line would involve reloading of material at Baker, the nearest town on a broad-gage railroad. The region is connected with outside points by the John Day Highway, which is in excellent condition.

\section{GEOLOGY}

The older rocks of this region consist of Paleozoic and Mesozoic mud, sand, limestone, and lava which have been subjected to moun-

\footnotetext{
${ }^{25}$ Pardee, J. T., and Hewett, D. F., Geology and mineral resources of the Sumpter quadrangle: Mineral Resources of Oregon, vol. 1, no. 6, p. 71, 1914.

${ }^{80}$ Chaney, R. W., The Mascall flora: Carnegie Inst. Washington Pub. 349, p. 29, 1925.
} 
tain-making forces, repeatedly folded and faulted, and then intruded by granitic rocks. Above these pre-Cretaceous rocks lies a series of later Tertiary rocks showing a certain amount of folding and deformation but no such alteration as characterizes the older series.

Pardee and Hewett ${ }^{37}$ compare the younger Tertiary rocks with the section of the John Day region, as follows:

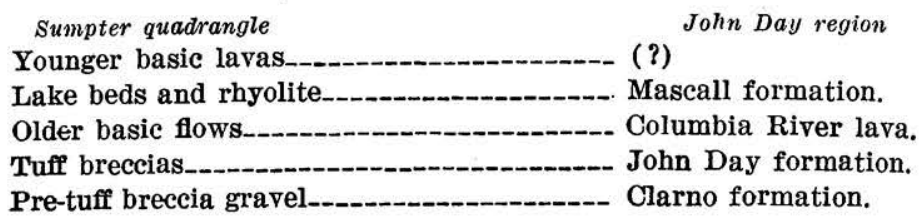

The lower members of this series, the tuff breccia and the gravel, form irregular and spotty areas representing the effects of the mountain-making activity recorded in the Crooked River region between the Clarno and John Day formations and in the John Day country between the John Day formation and the Columbia River lava. The older basic flows of Pardee and Hewett are continua. tions of the Columbia River lava of the John Day region, and al. though individual flows are probably not continuous they are un. doubtedly the same series, though not represented in their full thickness.

The lake beds of the Sumpter quadrangle are composed of tuffa. ceous sediments, according to Pardee and Hewett, and include gravel, clay, marl, and coal much like the Mascall and Payette formations. At several places diatomite occurs. Fossil floras have been collected from the diatomite in sec. 4, R. $35 \frac{1}{2}$ E., T. $11 \mathrm{~S}$. According to Chaney ${ }^{38}$ these floras are typically Mascall and thus check the correlations obtained by other methods.

\section{DIATOMITE}

Little time was spent in this region, and only two localities were examined-one on the loop of the Sumpter Valley Railroad near Tipton and the other near Austin.

\section{TIPTON}

The occurrence of diatomite in the railroad cut near Tipton is in sec. 4, T. 11 S., R. $351 / 2$ E. Here clayey diatomite with partings of volcanic ash is overlain by a basaltic lava flow. The diatomite has a maximum thickness of 40 feet and occupies a window formed by the erosion of the lava, the area of which according to Pardee and Hewett's map is about 160 acres. The beds rest on the Columbia River lava and dip about $8^{\circ} \mathrm{S}$.

${ }^{37}$ Pardee, J. T., and Hewett, D. F., op. cit., p. 47.

-3s Chaney, R. W., op. cit., p. 29. 
A sample (no. 6) is of rather low grade as shown by color and weight, and although it might be utilized in making clay-bonded diatomite bricks, its distance from centers of consumption and the presence of high-grade deposits in the region render it commercially useless.

\section{AUSTIN}

A deposit just west of Austin, in sec. 28, T. 11 S., R. 35 E., contains a large quantity of high-grade diatomite. Its areal extent is unknown, as timber and soil mask most of the area. It is probable that prospecting in this area by drilling would reveal a large amount of material similar to that exposed in the railroad cut about a quarter of a mile south of Austin.

The diatomite is very pure, massively bedded material with thin partings of volcanic ash. Local disturbances have faulted the formations, resulting in the downthrow of the diatomite against diabase in the east end of the cut. Several clastic dikes of gray volcanic ash cut the beds at intervals of 20 to 30 feet, and in places the diatomite is fractured or crushed. The strike is east-west, and the dips near the fault are about $40^{\circ} \mathrm{S}$. The diatomite is exposed for a distance of about 300 feet along the track. The depth of the cut is about 20 feet, and the soil cover is from 2 to 3 feet thick. The total stratigraphic thickness in this section is not less than 100 feet, and the rise of the ground to the west suggests a greater thickness of diatomite under the hill.

As shown by color and weight, this diatomite is of fine quality. A sample was examined by Kenneth E. Lohman, who reports as follows:

Sample 1035, Austin, Grant County, Oreg., railroad cut in sec. 21, T. 11 S., R. 35 E.; B. N. Moore, no. 7 (pl. 6, F).

The only visible impurities in this sample are small amounts of volcanic ash and clay, with possibly a little organic matter. The diatoms are dominantly small, ranging from 0.002 to 0.016 millimeter in diameter, with maximum length seldom exceeding 0.025 millimeter. Rare forms attain a length of 0.14 millimeter. The diatoms are clean, and less than 5 percent are broken.

The princinal species of diatoms are the following:

\footnotetext{
Melosira granulata (Ehrenberg) Ralfs. Abundant.

Melosira granulata var. curvata Grunow. Abundant.

Fragilaria brevistriata Grunow. Few.

Melosira arenaria Moore. Few.

Melosira cf. M. sol Ehrenberg. Few.

Tetracyclus ellipticus (Ehrenberg) Grunow. Few.

Tetracyclus lacustris Ralfs. Few.
}

Total number of species found, 21.

This material might be used for most purposes for which diatomite is fitted, though it is not tough enough to be used for the production of sawed natural brick. 


\section{PLATE 7}

A. Sample 98 from locality on John Day River, Grant County.

1. Coscinodiscus sp. c (fragment).

2. Melosira crenulata var. tenuis Kützing?

B. Sample 73 from locality near Brogan, northern Malheur County.

1. Coscinodiscus cf. 0 . lacustris Grunow.

2. Melosira granulata (Ehrenberg) Ralfs.

3. Melosira granulata var. curvata Grunow.

C. Sample S7 from Harper district, Malheur County.

1. Melosira distans var. lyrata (Ehrenberg) Bethge.

2. Melosira granulata var. curvata Grunow.

3. Melosira granulata var. spiralis Grunow.

D. Sample T3 from Harper district, Malheur County.

1. Melosira granulata var. curvata Grunow.

$E$. Sample U4 from Harper district, Malheur County.

1. Melosira granulata (Ehrenberg) Ralfs.

F. Sample V2 from Harper district, Malheur County.

1. Melosira distans var. lyrata (Ehrenberg) Bethge. 
U. S. GEOLOGICAL SURVEY
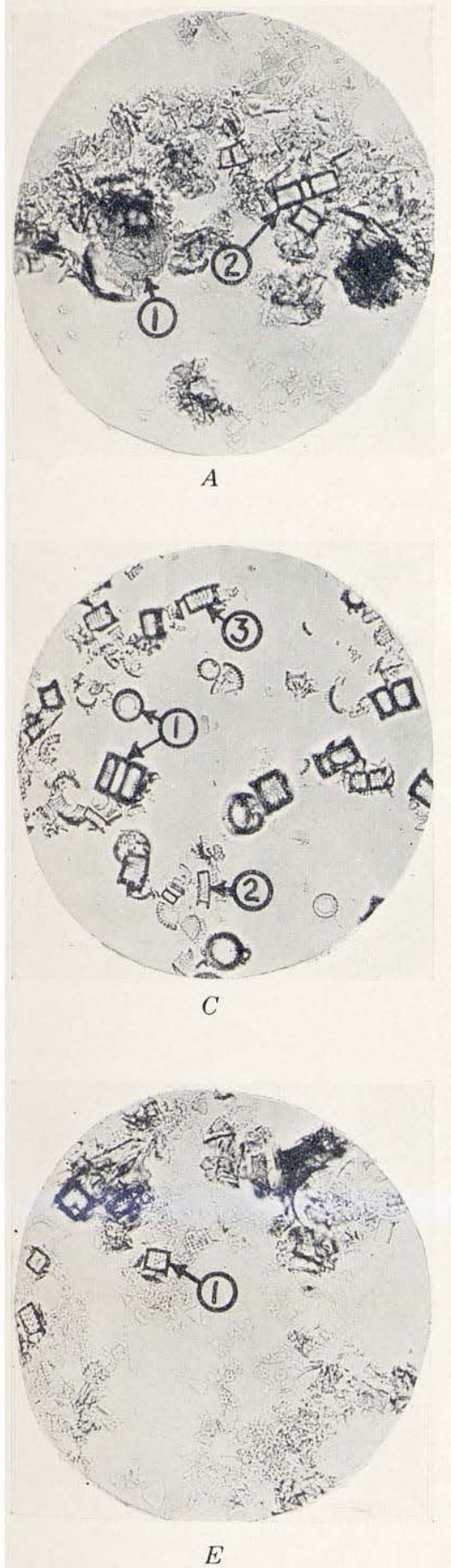
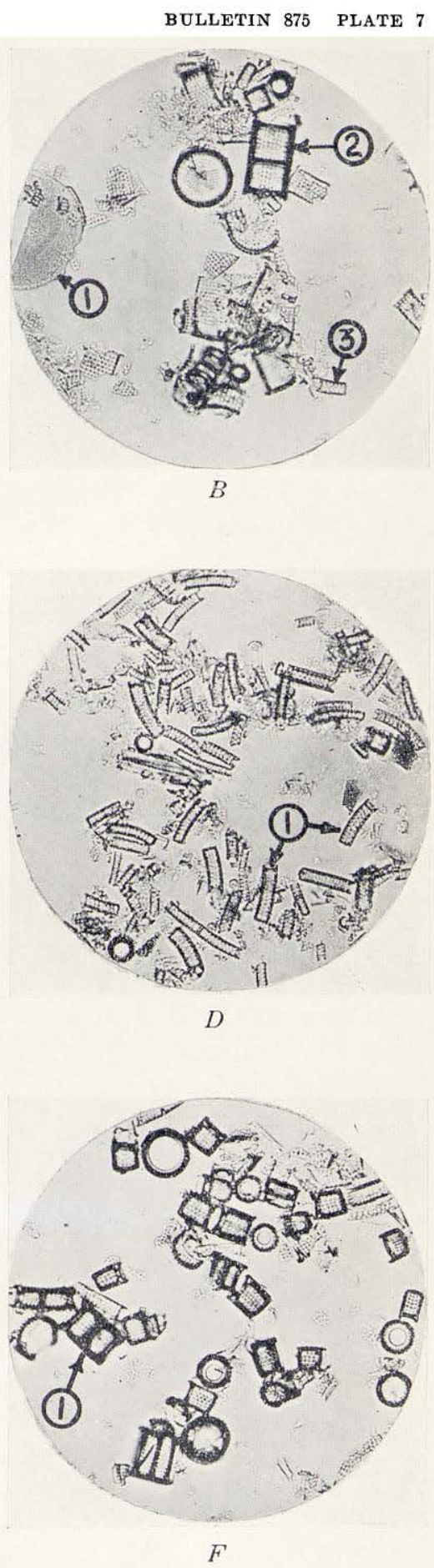

PHOTOMICROGRAPHS OF STREWN MOUNTS OF UNCLEANED DIATOMITE OF EASTERN OREGON.

Enlarged 300 diameters. Photographed by K. E. Lohman. 
If this deposit is considered to be 300 feet long, as exposed in the railroad cut, 300 feet wide, and 5 feet thick, a conservative estimate would be about 5,000 tons, but if the deposit underlies half a section, which is a reasonable postulate, from 750,000 to $1,000,000$ tons is available. Although undeveloped, this deposit warrants study in the investigation of future producing diatomite districts.

\section{JOHN DAY VALLEY}

Diatomite occurs in the Mascall formation of the John Day Valley. This formation, which lies conformably upon the Columbia River lava, is well dated by a large and excellently preserved fauna that has been studied by Merriam ${ }^{39}$ and his associates. Litho. logically, this formation is very similar to other lake-bed formations of middle Miocene age in eastern Oregon. It is composed of fine yellow tuffaceous beds largely altered to bentonitic clay, with lesser amounts of sand, gravel, and low-grade lignite. Diatomite beds occur at several localities associated with the lignite.

The diatomite of this region is impure and has no commercial application. Sample 98 was collected in a road cut on the north side of the John Day Highway in sec. 9, T. 13 S., R. 28 E. Its color and weight show this material to be of no value. The exposed thickness of the beds is about 10 feet, which includes some thin seams of clay and lignite.

Although this material is of no economic value, its occurrence in the well-known and well-dated Mascall formation makes it of considerable scientific interest. Its exact position in the section with respect to the vertebrate fossils is not known, but as these are generally considered to be of middle Miocene age, it is believed that the diatomite is close to the same age. A sample of this material was submitted to Kenneth E. Lohman, who furnished the following report:

Sample 1029, John Day River district, Grant County, Oreg., sec. 9, T. 13 S., R. 28 E.; B. N. Moore, no. 98 (pl. 7, A).

This sample contains considerable clay and probably some organic matter. Although the dominant diatom is a large disk with an average diameter of 0.06 millimeter, the material is so highly shattered that very few of the fragments have a maximum dimension in excess of 0.025 millimeter. Nearly all the diatoms are broken; even small forms 0.005 millimeter in diameter are rarely whole. The diatoms are fairly clean, but some of them are contaminated with clay and organic matter.

The principal species of diatoms are as follows:

Coscinodiscus sp. c. Dominant.

Melosira crenulata var. tenuis Kutzing? Common.

Melosira granulata (Ehrenberg) Ralfs. Rare.

\footnotetext{
${ }^{30}$ Merriam, J. C., A contribution to the geology of the John Day Basin; California Univ., Dept. Geology, Bull., vol. 2, no. 9, pp. 305-310, 1901.
} 


\section{BROGAN}

A deposit of diatomite occurs in the Payette formation near Brogan, 25 miles north of Vale, on the Brogan branch of the Oregon Short Line. The thick series of beds of the Payette of the Vale region commences to thin westward, and on the road to Malheur it laps onto the pre-Cretaceous argillites and greenstones. Overlying the lake beds are lavas of presumably Pliocene age.

Specimen 73 was collected from the northwest side of the Brogan. Malheur road 2.7 miles from Brogan, in sec. 2, T. 15 S., R. $42 \mathrm{E}$. Here, about 100 feet below the capping lavas, the following section was measured:

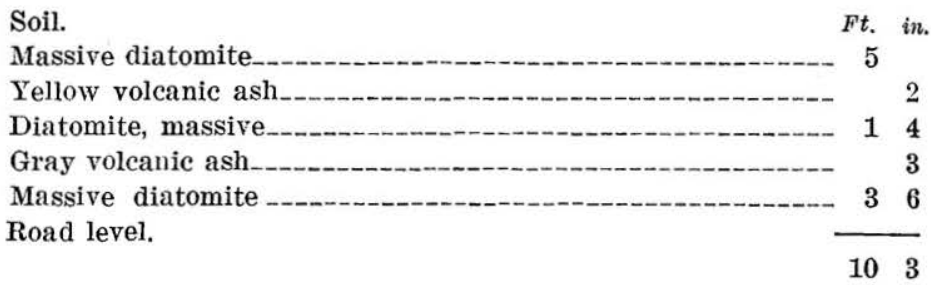

The specimen was collected from the lower bed. Color and weight show it to be only of fair quality. This material, because of its quality and mode of occurrence, is regarded as of no economic value. Kenneth E. Lohman has contributed the following report on this sample:

Sample 1031, Brogan, Malheur County, Oreg., sec. 2, T. 15 S., R. 42 E.; B. N. Moore, no. 73 (pl. $7, B$ ).

The visible impurities in this sample are very few, consisting of minute amounts of volcanic ash and clay. There is a fairly uniform distribution of different-sized diatoms and fragments between a maximum of 0.05 millimeter and a minimum of 0.004 millimeter, with a small percentage of small fragments down to 0.001 millimeter. About 60 percent of the larger forms and about 20 percent of the smaller forms are broken. The diatoms are fairly clean.

The principal species are as follows:

Melosira granulata (Ehrenberg) Ralfs. Dominant.

Melosira granulata var. curvata Grunow. Common.

Coscinodiscus cf. C. lacustris Grunow. Common.

Melosira granulata var. Few.

Melosira cf. M. solida Eulenstein. Rare.

Tetracyclus ellipticus (Ehrenberg) Grunow. Rare.

Tetracyclus javanicus Hustedt. Rare. 


\section{HARPER DISTRICT}

\section{LOCATION}

The Harper diatomite district is in the north-central part of Malheur County, in east-central Oregon.

\section{INVESTIGATIONS}

No published data on the Harper district have previously beer available aside from scattered brief mentions of this deposit as one of the diatomite deposits of eastern Oregon. In 1930 R. W. Richards and I spent a week in this district, and in 1931 I spent 4 weeks in the field preparing the accompanying map (pl. 8). Though the map is only a sketch, it is believed that the major features of this deposit have been outlined.

I am indebted to many persons in Harper for courtesies extended during the examination of the district. To Mr. W. G. Morgan, then secretary and general manager of the Pacific Coast Diatom Corporation, I am especially indebted for unrestricted permission to examine the properties of that company. Mr. J. D. Fairman, then treasurer of the same company, also furnished much information and extended many courtesies.

\section{GEOGRAPHY}

The Harper diatomite district extends in a general way from the Malheur River northwestward to Westfall, a distance of about 12 miles. The district is an irregular basin cut out of the old plateau surface of central Oregon by the Malheur River and its tributary Bully Creek. It is roughly mushroom-shaped, its base lying parallel to the Malheur River and a little south. It is constricted between Harper and Westfall but spreads out in an irregular fashion along Bully Creek. The basin occupies more than 50 square miles, much of which is underlain by high-grade diatomite.

The altitude of the town of Harper is 2,615 feet. Westfall is about 3,000 feet above sea level and is separated by a low divide of only 100 feet from the Malheur drainage basin. The bottom lands of the basin are rolling, though there are several low hills. The surrounding hills range in altitude from 3,500 to 4,000 or 4,500 feet. The eastern boundary of the district is the most prominent. It is formed of a nearly flat-topped basalt-capped mountain 3,500 to 4,000 feet in altitude and convex to the west. The western slope is a pronounced cliff of lava, below which the white beds of diatomite are exposed. Through this cliff the Malheur River and Bully Creek have cut gorgelike canyons. The hills to the west do not present so striking a picture, though they are considerably higher. Landslides are common along their slopes and have resulted in a vast confusion of large and 
small blocks of lava, which cover the diatomite and tuff. Although the diatomite does not continue far to the south of the Malheur River, the tuffs do, and there a series of rounded hills rise for several miles southward until the lava cap of the old plateau is reached. To the north the old plateau is similarly dissected, and for more than 10 miles in that direction from Westfall the traces of the old surface on the stream divides can be followed until they merge to form the gently rolling surface that extends north to Bonita, nearly 30 miles distant.

\section{ACCESSIBILITY}

Harper is on the Ontario-Burns branch of the Oregon Short Line. The town, which was formerly connected with the outside by poor roads, is about a mile from the Central Oregon Highway, which is well graded and oiled. The deposits of diatomite are easily reached from a new market or secondary State road between Harper and Westfall. Short roads to the various properties from this artery afford excellent conditions for trucking.

\section{GEOLOGY}

The rocks of the Harper diatomite district are all of Tertiary and Quaternary age. They include lavas correlated with the upper part of the Columbia River lava, a local facies of the Payette formation, lava flows of probable Pliocene age, and some later rocks. With the exception of the diatomite the rocks are of volcanic origin, the tuffs, however, being water-sorted.

The oldest lavas are interbedded with the lower part of the Payette formation, which is represented in this district by a large number of members, all separated by noticeable unconformities. Lying across the edges of these beds is a series of lavas, probably Pliocene, in which valleys have been carved and filled with Pleistocene lava and gravel that have themselves been dissected and now cap ridges and terraces of the present topography. The distribution of these rocks is shown on plate 8 , and the relations of the rocks are summarized in the following table: 
Stratigraphic sequence in the Harper district

\begin{tabular}{|c|c|c|c|c|}
\hline Age & \multicolumn{2}{|c|}{ Formation } & Character & $\begin{array}{l}\text { Thickness } \\
\text { (feet) }\end{array}$ \\
\hline Recent. & \multicolumn{2}{|l|}{ Alluvium. } & Silt from diatomite and tuff. & \\
\hline $\begin{array}{l}\text { Late Pleistocene } \\
\text { (?). }\end{array}$ & \multicolumn{2}{|c|}{ Terrace gravel. } & Rounded river-worn lava cobbles. & $0-20$ \\
\hline Unconformity- & \multirow{2}{*}{\multicolumn{2}{|c|}{ Vitrophyre flows. }} & & \\
\hline $\begin{array}{l}\text { Early Pleisto- } \\
\text { cene (?). }\end{array}$ & & & $\begin{array}{l}\text { Dark glassy porphyritic lavas in region of } \\
\text { Westfall. }\end{array}$ & $0-100$ \\
\hline $\begin{array}{l}\text { Unconformity- } \\
\text { Upper Pliocene } \\
\text { (?). }\end{array}$ & \multicolumn{2}{|c|}{ Capping basalts. } & $\begin{array}{l}\text { Flows of lava, mainly olirine basalt, cap- } \\
\text { ping Payette formation. }\end{array}$ & 0100 \\
\hline \multirow[t]{4}{*}{ Unconformity- } & \multirow{6}{*}{$\begin{array}{l}\text { Payette for- } \\
\text { mation. }\end{array}$} & $\begin{array}{l}\text { Yellow tuff mem- } \\
\text { ber. }\end{array}$ & Fine-grained tuff, in part bentonitic clay. ${ }^{1}$ & $100-500$ \\
\hline & & $\begin{array}{l}\text { Rhyolite porphy- } \\
\text { ry member. }\end{array}$ & Flow of light-gray lava. & $0-10$ \\
\hline & & $\begin{array}{l}\text { Upper diatomite } \\
\text { member. }\end{array}$ & $\begin{array}{l}\text { Thick-bedded diatomite with partings of } \\
\text { volcanic ash. }\end{array}$ & $0-175$ \\
\hline & & $\begin{array}{l}\text { Gray ash mem. } \\
\text { ber. }\end{array}$ & $\begin{array}{l}\text { Sandy gray volcanic ash with pinnacle } \\
\text { forming bed near center. }\end{array}$ & $60-150$ \\
\hline \multirow{3}{*}{ Miocene. } & & $\begin{array}{l}\text { Lower diatomite } \\
\text { member. }\end{array}$ & $\begin{array}{l}\text { Thick-bedded diatomite with partings of } \\
\text { volcanic ash, silicified near base. }\end{array}$ & 450 \\
\hline & & $\begin{array}{l}\text { Lower agglom- } \\
\text { erate and tuff } \\
\text { member. }\end{array}$ & $\begin{array}{l}\text { Yellow tuff and well-stratifled agglom. } \\
\text { erate interbedded with lava. }\end{array}$ & $100-200$ \\
\hline & \multicolumn{3}{|c|}{$\begin{array}{l}\text { Flows of olivine basalt and hypersthene andesites correlated with the Colum- } \\
\text { bia River lava. }\end{array}$} & \\
\hline
\end{tabular}

${ }^{1}$ Has yielded vertebrate fossils assigned by E. L. Furlong (Carnegie Inst. Washington Pub. 418, pp. 27-36, 1931) to the lower Pliocene.

\section{MIOCENE LAVAS}

Basaltic lavas are the oldest rocks represented within the area mapped and crop out in secs. 28 and 29 , T. 19 S., R. 42 E.; secs. 16 and 17, T. 18 S., R. 41 E.; and secs. 29 and 30, T. 18 S., R. 42 E. These lavas occur as more or less broken flows of a black fine-grained basalt which weathers rusty red. On freshly fractured surfaces numerous rusty spots, presumably representative of olivine phenocrysts, can be observed on the finely crystalline groundmass.

The occurrence in secs. 29 and 30, T. 18 S., R. 42 E., shows the relation of these rocks to the overlying series. Here a flow of the lava 
crops out along Bully Creek. It has columnar joints and displays the same general appearance as the Columbia River lava. Overlying this flow is about 50 feet of a fine-grained well-stratified olive-green agglomerate, which is followed by another flow of the same sort of lava, and this in turn is overlain by more agglomerate and tuff.

In secs. 28 and 29, T. 19 S., R. 42 E., the same lavas crop out: Here they are considerably jointed, and at their contact with the overlying diatomite and gray ash they appear to be fractured and badly altered. Along the rather irregular contact several warm mineral springs occur, but the exact structure was not determined. Mineral springs are rather common in this region.

The stratigraphic relations of these lavas to the Payette formation in this district and the fact that they form a continuous outcrop to the John Day Valley suggest that they are part of the Columbia River lava of that region, even though they may not be of exactly the same age as similar lavas elsewhere.

\section{PAYETTE FORMATION}

Resting on Miocene lava in the Snake River region of Idaho and Oregon is a series of tuffs and other sediments known as the "Payette formation." At Harper this series of sediments is divisible into several members, separated by unconformities and reflecting the changes in the size and depth of the great lake represented by the Payette formation.

In the upper member vertebrate fossils have been collected that have been identified by Furlong as lower Pliocene. The rest of the formation is generally assigned to the Miocene.

\section{LOWER AGGLOMERATE AND TUFF MEMBER}

The basal member of the Payette formation is composed largely of regularly bedded water-laid agglomerate and tuff. In the area along Bully Creek it consists of about 200 feet of well-bedded agglomerate and tuff of olive-green color. No pronounced crossbedding was noted. The agglomerate beds range from a few inches to a few feet in thickness and are made up of coarse tuff and lapilli, including pieces an inch or more in diameter. The lapilli have an olive-green color and appear on the inside to be altered fragments of basalt and andesite. They are round but not at all smooth, the surfaces being rough and pitted, with no suggestion of stream abrasion or polishing. The tuff is likewise formed of altered lava fragments, and both tuff and agglomerate are well cemented. Associated with the tuff and agglomerate beds are a few beds of fine conglomerate made up of small, well-rounded and polished pebbles of white 
quartzite and rare chert. The matrix is a sandy tuff, and the rock is well cemented.

These sediments were probably derived from nearby areas of fragmental volcanic material which was washed by streams into the shallow lake and there sorted by wave action. The source of the quartzite in these pebble beds is unknown. It was doubtless swept into the lake at different intervals by streams from areas of preCretaceous rocks.

The exact age of this agglomerate is not known. On Bully Creek it is clearly interbedded with lava like that underlying it.

Sediments occupying a similar stratigraphic relation to the agglomerates crop out a few miles north of Harper along the irrigation canal. They are overlain by the lower diatomite but consist of olive-green sandy tuffs. A pebble bed formed of small, well-rounded pebbles similar to those on Bully Creek was noted. The maximum thickness of these tuffs as exposed is not much over 100 feet.

\section{LOWER DIATOMITE MEMBER}

The eroded edges of the lowermost beds of the Payette formation are overlapped by 450 feet of diatomite and associated volcanic dust and sand. The diatomite is rather uniformly pure, light in weight, white, and in most places free of grit. More than half of the section is formed of diatomite, the rest being volcanic ash or dust. The diatomite occurs in beds ranging from an inch to 5 feet in thickness between partings. The beds are not laminated and are sharply bounded by partings of gray volcanic ash. The volcanic ash is made up of a loosely coherent gray fine-grained glass, which forms beds from a quarter of an inch to nearly 40 feet in thickness. The thin partings have a surprisingly uniform thickness, and the boundaries between the ash and diatomite strata are sharp and clean.

A very interesting point in connection with this deposit is the almost universal silicification of some of the lower beds. In the region to the east of Harper, where the lower part of the section is exposed, there is little commercial diatomite, the greater part being hardened to a chinalike mass which in many places is still further silicified to a smooth brown to white cherty rock. The position of the beds suggests that silicification was perhaps caused by circulating underground waters, including alkaline mineral waters, which form numerous springs in the region. Microscopic examination reveals no trace of original diatom structure in the completely silicified cherts. The opaline material forms a continuous isotropic mass broken only by particles of clay and ash.

The diatomite beds of this member are widely distributed in the district. The greater part of them are free from the objectionable 
silicification above mentioned, and in them is located the main quarry of the Pacific Coast Diatom Corporation.

GRAY ASH MEMBER

Overlying the lower diatomite member unconformably is a mem. ber composed of gray ash and pumice, ranging in thickness from 60 to 150 feet. It is distributed throughout the district and may be found wherever erosion has spared the overlying diatomite. In the region around Westfall it was not mapped separately from the lower diatomite member.

This member consists of two distinct varieties, which, however, aro not separated by sharp boundaries. A lower fine-grained gray ash grades upward into a thick bed of coarse pumiceous ash and agglom. erate, locally consolidated to form a resistant bed weathering to striking pinnacled shapes. Above the pinnacle-forming ash there is more of the finer material. This member is recognizable in the field by its thickness and continuity.

The middle pinnacle-forming part laps over the fine-grained ash, which is in places more than 30 feet thick, onto the lower diatomite member. Incorporated in the lower part of the stratum are large boulders of diatomite, as much as 2 or 3 feet in diameter, which have been worked in with the ash.

The lower part of the gray ash member was deposited from ash showers, for it lacks other material which would accompany it were it water-laid. The coarser material represented by the pinnacleforming beds, however, resembles a mud flow in places. This is particularly true with respect to the thick agglomerate in sec. 13, T. 19 S., R. $41 \mathrm{E}$. This material is brown and formed of a muddy tuff in which are embedded small fragments of cinderlike vesicular lava. Traced southward this gives way to the normal gray pumiceous ash.

UPPER DIATOMITE MEMBER

Lying unconformably upon the gray ash member are beds of diatomite 150 feet in maximum total thickness. Compared to the lower diatomite member these beds occupy a relatively small area, being limited to a narrow strip along the eastern margin of the district and to several flat-topped benches on the west side.

A noteworthy feature of this member is the absence of thick beds of volcanic ash. With few exceptions the ash is confined to thin partings. The upper diatomite strata are rather thicker than the lower ones, and the percentage of beds under 1 foot in thickness is relatively low. Most of the beds are from 3 to 5 feet thick. In some sections ashy beds are found, but these also are smaller in number and thickness than in the lower diatomite member. 
An irregular contact with the gray ash indicates that there is an unconformity between the two members.

\section{RHYOLITE PORPHYRY MEMBER}

Overlying the upper diatomite member in the central portion of the district is a flow of rhyolite porphyry. Unconformable relations are shown by the rapid thinning out of the upper diatomite between sec. 2 and sec. 6, T. 19 S., R. 41 E. In sec. 2 about 175 feet of the upper diatomite is represented, whereas in sec. 6 the rhyolite rests directly on the gray ash.

The rhyolite is a light-gray rock, weathering brown. It is jointed into large but thin slabs. On fresh fracture it has a definitely glassy look, with small brilliant phenocrysts set in the cracked glass. Under the microscope the phenocrysts are seen to be irregular corroded grains of feldspar with small weathered black mica and opaque grains of magnetite. The glass has a suggestion of perlitic structure.

To the west this flow is replaced by gray ash, which was deposited contemporaneously.

YELLOW TUFF MEEMBER

Overlying the rhyolite porphyry member with a well-marked unconformity is a series of tuffaceous beds. In the hills to the north of Harper they lie across the eroded edges of the upper diatomite and gray ash members.

The tuff is for the most part fine-grained, sandy, thin-bedded, and tawny yellow. In a few places there is a thin bed of diatomite. Locally pebble beds and ash beds may be found. Much of the tuff is altered to a bentonitic clay. These beds are very similar in lithology to the beds of the Payette formation farther east. They represent material deposited in shallow lakes.

This member is distributed in the Harper district as a narrow band under the overlying and capping basalt flows, though south of the Malheur River it covers all the older members. Vertebrate remains ${ }^{40}$ have been collected from these beds at a point near the Central Oregon Highway, some 2 miles southeast of Harper, which resemble the assemblage from the Pliocene beds in Nevada that have been designated "Thousand Creek formation" by Merriam. Similar remains were collected on the flat east of quarry 10, in sec. 34 or 35 , T. 18 S., R. 41 E., but they were not in place.

\section{POST-PAYETTE ROCKS}

CAPPING BASALTS

Capping the sedimentary series are several extensive basalt flows, the eroded edges of which form a distinct boundary to the district.

${ }^{\omega}$ Stock, Chester, and Furlong, E. L., personal communication. 
The lava has columnar joints and weathers rusty brown on the exposed surfaces. On fresh surfaces it is black, plainly holocrystal. line, open-textured, and vesicular. A sample from sec. 3, T. $20 \mathrm{~S}$., R. 42 E., was examined under the microscope and found to consist of labradorite, augite, olivine, and magnetite. The labradorite occurs as a network of small lath-shaped crystals, around which the augite has grown. In the open interstices between some of the feldspar crystals small grains of olivine may be found. The magnetite occurs in small irregular masses scattered through the groundmass. Labradorite and olivine phenocrysts occur here and there.

These lavas are unconformable on the underlying formation. In sec. 12 , T. 19 S., R. 41 E., they form a continuous cliff, which extends across the eroded edges of faulted yellow tuff and the gray ash member of the Payette formation. In general the lavas lie on the yellow tuff, which is of variable thickness.

The age of the lavas is not exactly known, but they are tentatively classified as upper Pliocene (?). They occupy similar stratigraphic positions to those of the thick series of lavas in the Owyhee, Steens Mountain, and other regions.

VITROPHYRES

In the region around Westfall there are numerous lava flows covering old hill slopes. These lavas are considerably younger than the capping basalts, as the topographic forms which they cover were cut not only through the capping lavas but deeply into the Payette formation. Their exact age is unknown, but an assignment to early Pleistocene time, based on the history of the basin, is probably close.

These rocks were not examined in any detail, but field observation showed that the flow in secs. 10 and 11, T. 18 S., R. 41 E., is a vitrophyre or porphyritic glass. The material is roughly jointed in columnar fashion and on weathered surfaces is rough and reddisin brown. The fresh fractures showed a black glassy ground mass thickly studded with glassy feldspar phenocrysts. In the SW $1 / 4 \mathrm{sec}$. 20 and the NW1/4 sec. 29 , T. 18 S., R. 41 E., there are remnants of necks which may represent feeders of these flows.

TERRACE GRAVEL

In the region south of Westfall, in secs. 27,28 , and 29, T. 18 S., R. 41 E., there are extensive patches of old terrace gravel, deposited during the cutting of the present basin by the Malheur drainage system. These deposits are formed of cobbles of basalt and andesite, largely from 2 to 6 inches in diameter, subangular in shape and some of them polished. The thickness is variable, but there is a maximum of about 20 feet. The height of the terraces above the present bed of Bully Creek is about 60 feet. 
Older deposits of terrace gravel have been noted in the west center of sec. 15, T. 18 S., R. 41 E., on the summit of the ridge just north of a prominent conical hill. Here there is about 5 feet of a basaltic river gravel at a height of about 250 feet above the present drainage level. Numerous other patches too small to show on a small-scaled map may be found at various places.

\section{RECENT ALLUVIUM}

There are two areas of recent alluvium in this district, one around Harper and one around Westfall. The surficial part is largely dust from the diatomite and tuff deposits, though gravel pockets occur along old stream channels. The exact thickness of the deposit is not known.

The alluvium cover over the greater part of the district is very thin, and in many places it is lacking. On the flatter portions there may be from 6 to 12 inches of diatomite dust, but along some hillsides there may be several feet of the dust mixed with fragments of the basalt cap rocks. The soil cover is so thin that the problem of its removal in mining operations is not of great importance.

\section{STRUCTURE}

The Harper Basin is an erosional feature cut in the soft sediments of the Payette formation, which are here protected from the downcutting of the Malheur River and Bully Creek by the temporary baselevel furnished by the resistant Pliocene lavas in the sharp syncline of Little Valley, 2 miles to the east. Although bounded on the east by a well-developed north-south syncline and on the west by northsouth faults in the Malheur Gorge, the rocks of the Harper district show no pronounced folding and but little faulting. The contact between Pliocene lava and Payette formation is remarkably constant in altitude. It is close to the 3,500-foot contour in the east-central part of the basin, but to the north, west, and south it rises gradually to about 4,000 feet in 10 to 20 miles. The synclinal appearance of the basin, which is so striking to the visitor, is due to actual and incipient slumping along the steep slopes of the basin walls, which in places show dips as high as $30^{\circ}$ toward the center of the basin.

\section{SLUMPING}

Slumping in the weak sediments forming the walls of the Harper Basin is a prominent feature and one that closely affects mining. Owing to the protective influence of the overlying Pliocene lavas the Payette formation has been weathered into land forms with steep slopes. Though the sediments underlying these slopes are sufficiently 
strong to stand by themselves and support heavy loads of other rocks when dry, they are very weak when wet because of their large content of diatomite and clay. They are thus ideal material for the development of slumping. Water from the scanty rainfall of the region percolates easily through the lavas and is absorbed by the clays and diatomite below. The weight of the rocks then exceeds the load that can be borne. A block cracks off and starts to slip down hill, toward the basin. The size of the blocks thus formed is variable.

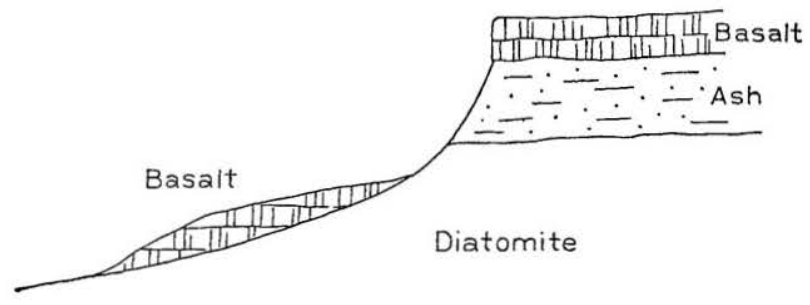

$A$

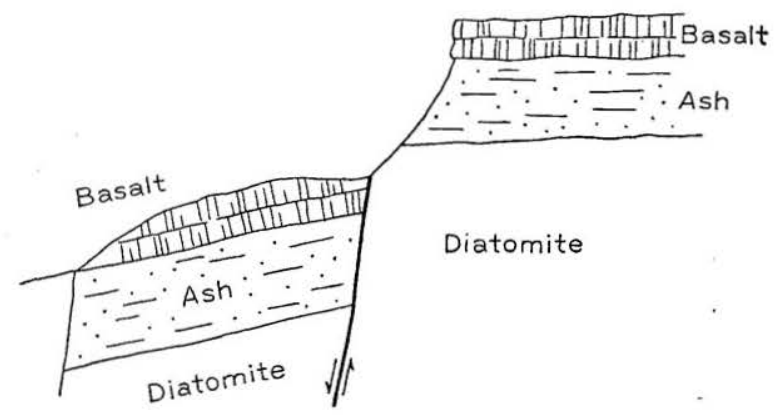

$B$

FIGURE 5.- Sketch illustrating difference between a slumped block (A) and a faulted block $(B)$ having similar outcrops.

Some may be an acre or so in extent and others more than a section (640 acres). The cracks along which the blocks separate from the main rock mass affect only the sliding block. These blocks slide down the slope slowly, usually a few feet a year. Many of the blocks themselves break up and form great broken masses of rock, which cover the lower slopes of the walls of the basin.

Slumping often produces outcrops which might be confused with outcrops produced by faulting. Care must therefore be taken to discriminate carefully between slumped blocks and faulted blocks. In figure 5 cross sections of two blocks are shown, one due to slumping, the other to faulting. 
An excellent example of slumping is to be found in the NW1/4 sec. 26, T. 19 S., R. 42 E. Here a block of Payette sediments covered by Pliocene lavas is slipping toward the Malheur River. The block is badly broken, as is shown by the numerous hummocks, some 100 feet in height. The Vale project irrigation canal (pl. 9, $A$ ) passes along the lower part of this block, and considerable trouble has been experienced with slippage. In view of the present position of the lava cap rock, the block has probably not yet reached its final resting place, and continual difficulty may be expected with the canal.

Other slumped blocks may be found along the east boundary of the basin. In the NE1/4 sec. 20, T. 19 S., R. 42 E., small masses of the capping lavas have slipped down and away from the rim and form the tops of several prominent buttes. In the $\mathrm{SE} 1 / 4$ sec. 18 , T. $19 \mathrm{~S}$., R. 42 E., larger masses of the capping flows have slipped down along with the underlying rocks. In secs. 2, 3, 10, and 11, T. 19 S., R. 41 E., the gray ash member of the Payette formation has slipped, producing what appears on first sight to be a complex fault pattern. On the west side of the basin there are also many slumped blocks, most of them larger than those on the east side. These are easily recognizable by their hummocky topography, indicative of broken strata, and their relation to the underlying rocks.

\section{FOLDS AND FAULTS}

The Harper district is bounded on the east by a sharp downfold in the Pliocene lavas. To this fold, which forms the west limb of the little Valley syncline, is largely due the present Harper basin, for the lavas, being resistant to erosion, form a temporary baselevel to which the streams may cut away the basin. No other folds have been recognized in the district. The unconformities between the different members of the Payette formation show signs of gentle folding, but the folds are not recognizable except on detailed mapping. The outcrops of the diatomite are controlled more by erosion than by structure.

Faults occur at several places in the district. One of the most interesting is that in secs. 12,13 , and 14, T. 19 S., R. 41 E. This fault is younger than the Payette formation and older than the Pliocene lava. To the northwest of the fault a section of the Payette beds including the yellow tuff, upper diatomite, gray ash, and lower diatomite members is exposed. On the southeast side only the gray ash and lower diatomite members are exposed. Lying across the fault are the Pliocene lavas, undisturbed. The areal pattern of the rocks suggests that this fault had its origin in upper diatomite time and that after the yellow tuff had been deposited over the eroded diatomite, further activity brought the gray-ash member south of the fault up against the yellow tuff north of the fault. 
Other faults occur in secs. 14, 15, and 16, T. 19 S., R. 42 E., but these faults have not been studied carefully. They are essentially vertical and involve not only the Payette formation but also the Pliocene lavas. Their orientation and age suggest that they are related to the faults of the Malheur Gorge.

\section{GEOLOGIC HISTORY}

The geologic history of the Harper district is an eventful one.

At the end of the outwellings of Miocene lavas in the Payette region a great shallow lake formed, of which traces have been found as far west as Drewsey, in northeastern Harney County, and as far south as Rome, in central Malheur County. In the vicinity of Harper the first sediments were basaltic and andesitic sand and gravel, ejecta from cinder cones, which were carried into the lake by streams and then sorted by the waves. An interesting feature in connection with these water-laid tuffs and agglomerates is the interbedded lava flow on Bully Creek, which might be considered to be among the last manifestations of the great activity of the Miocene lava field.

During the sedimentation of the lake, which was nearly continuous in the central part, near Payette, Idaho, there was a gradual sinking of the basin, except on the borders. In the Harper district the agglomerate and tuff beds were tilted, eroded, and then submerged. On them were laid down great thicknesses of the remains of diatoms, which flourished in great numbers in the lake. Occasional ash showers from neighboring volcanoes contributed beds of gray ash, which interrupt the continuity of the diatomite strata.

After the deposition of several hundred feet of the diatomite and ash beds, there was another crustal disturbance, and these beds in turn were exposed. Erosion had only started when the volcanic activity marked by the thin ash beds in the preceding series increased in intensity, laying down a great blanket of the gray ash and then culminating in a mud flow of pumiceous agglomerate and ash, followed by more of the finer material. This deposit of ash and agglomerate was then eroded and submerged. Again diatomite was deposited, but this time with smaller amounts of interbedded ash, owing to the subsiding of the volcanic activity. After the deposition of several hundred feet of diatomite another change elevated the sediments and tilted them slightly prior to a rhyolite flow which was either very local or was later almost completely removed by erosion. The basin again sank, and in the waters of the lake great thicknesses of yellow tuff were laid down. The tuff was formed of reworked volcanic sediments, which were well sorted in the shallow lake, and with it beds of clay and gravel and thin seams of diatomite were also deposited. These beds contain fossil vertebrates of Pliocene age. 


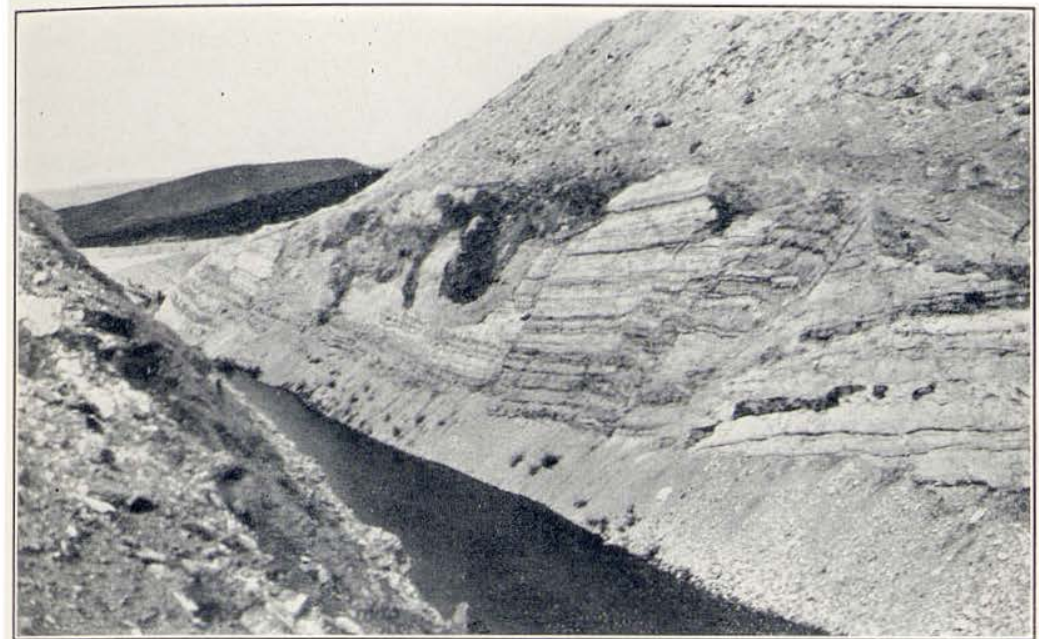

A. DISTORTED DIATOMITE IN BANKS OF VALE IRRIGATION CANAL.

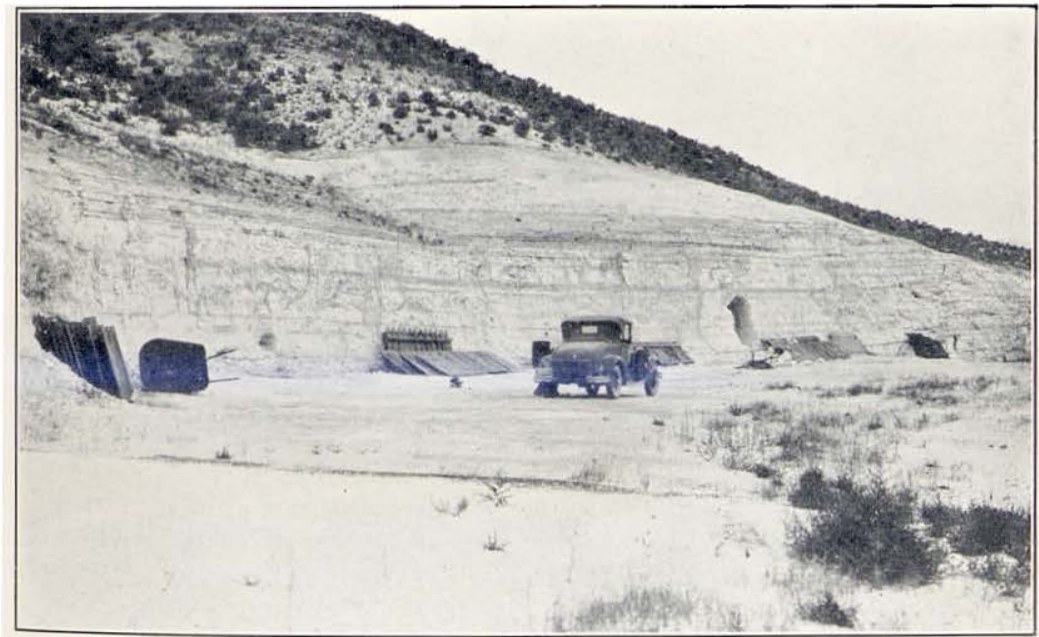

B. VIEW IN NO. 10 QUARRY OF PACIFIC COAST DIATOM CORPORATION, HARPER DISTRICT, MALHEUR COUNTY. 
During the deposition of the Payette formation in the Harper district the uplift of the present Ochoco Mountains had begun. The mountain-making forces may have affected the region to the south and thus have caused the tilting of the basin at different times. After the deposition of the yellow tuff containing Pliocene vertebrates, the basin was considerably warped, and the precursor of the Malheur River planed away the lake beds. On this eroded surface of the lake beds lavas were poured out, of which only eroded remnants are now present.

The history of the region from the outwelling of the Pliocene lavas to recent time is connected with the erosional history of the Malheur River. This stream, which drains a large part of the south slope of the Ochoco Mountains, flows into the Snake River. In its course through this region it has cut down through the lavas and lake beds, dissecting the flat surface of the central plateau. An excellent record of this process is to be found in the Harper district. After the river had excavated a basin in the soft sediments underlying the lavas there was further volcanic activity, and the vitrophyric lavas of Westfall covered old valley slopes. Further erosion then dissected these lavas, and on terraces formed during this dissection is found stream gravel from 50 to 300 feet above present stream level. At the present time the region is being dissected, and in some distant future it may be planed away by the Malheur River to the present featureless state of the Snake River Valley around Payette.

\section{DIATOMITE}

\section{DISTRIBUTION}

The diatomite of the Harper district occurs in massive condition in beds separated by partings of gray ash. The lack of lamination in this material is noteworthy, as well as the surprisingly large percentuge of very pure material. Comparatively little of the diatomite carries an appreciable percentage of ash or clay. During the investigation several sections were measured, which are here given, as they will convey a much better idea of the mode of occurrence of the diatomite than any other description can. The results of the sections are summed up in figure 6 , in which the larger units and the suggested correlations are shown. The location of the sections is shown on plate 8. Except where slopes were absolutely free of soil or where prospect trenches were available no detailed sections were made. These sections were measured by using a Brunton compass as a level and are therefore accurate to only about 10 percent.

Section $1, \mathrm{~W} 1 / 2$ sec. 15, T. 18 S., R. 41 E. The locality is well marked as it is on the west slope of a white conical hill. 


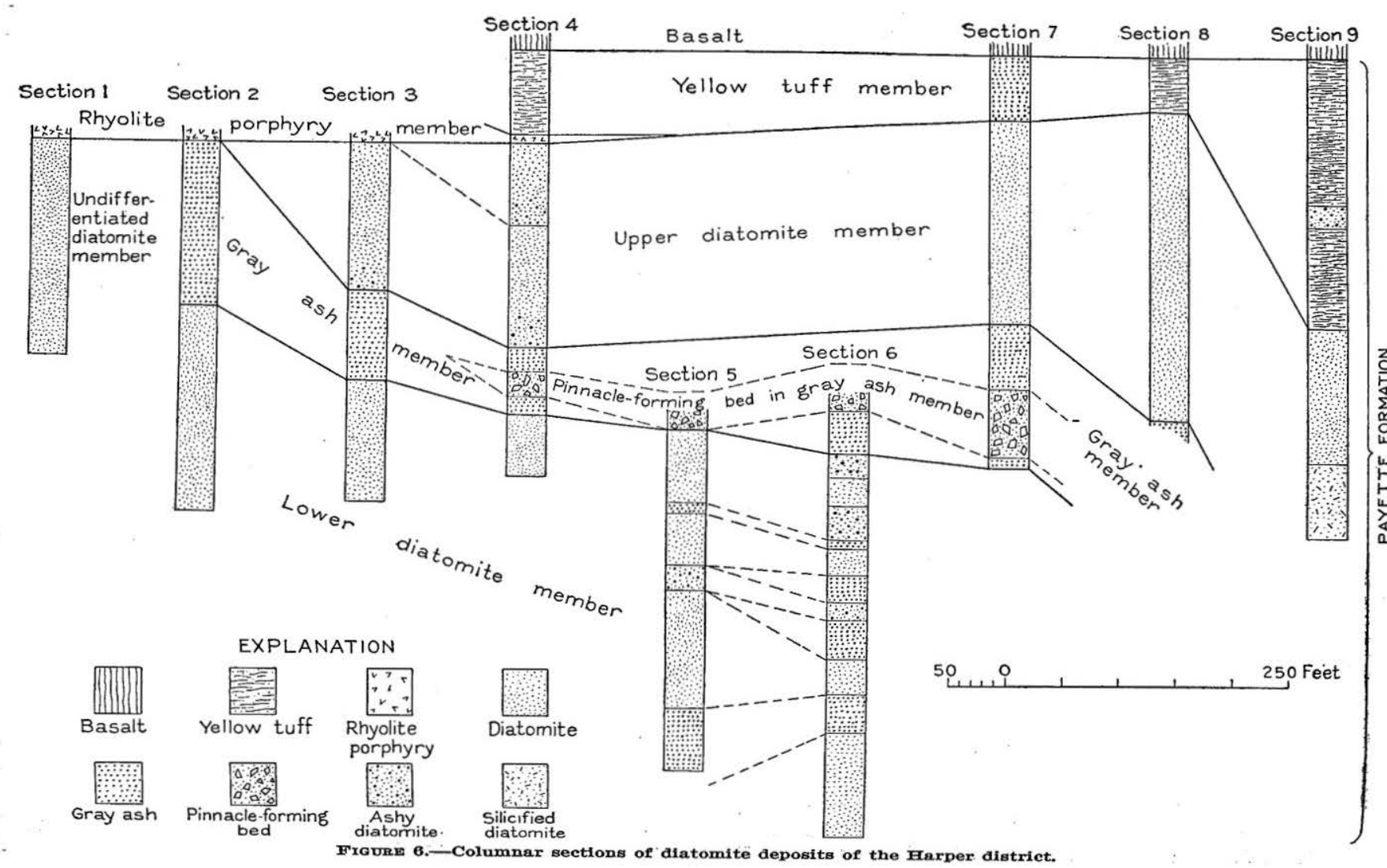


Summit.

Terrace gravel: Rounded stream gravel with fresh angular blocks of a gray rhyolite at the base_

Ft.

Unconformity.

Diatomite with several thin partings

Unconsolidated gray ash

Diatomite in beds 1 to 3 feet thick separated by thin ash partings (sample T6, 8 feet above base)

Fine gray unconsolidated ash

Diatomite with thin partings (sample T5, from base) --.---.--

Coarse loosely consolidated gray ash.

Diatomite in beds 3 to 6 feet thick separated by partings of gray and yellow ash 1 to 3 inches thick (sample T4, 11 feet above base)

Section examined in more detail:

Diatomite

Ft. in.

Gray ash

3

Diatomite -

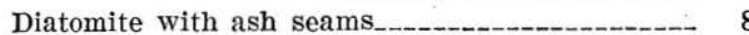

Gray ash _-_-_- 2

Diatomite _._.

Ashy diatomite_.._.

Gray ash _._.

Diatomite with thin ash seams_-_-_._-_-_-_ 8

Gray ash _-_-_- 1

Diatomite - -

$\begin{array}{llll}\text { Thin-bedded ash and diatomite____________-_._. } & 3 & \mathbf{6}\end{array}$

Diatomite (sample T3)

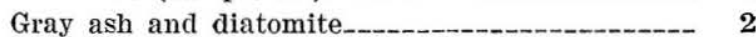

Diatomite with thin partings _______________ $11 \quad 6$

Yellow tuff _-_. 2

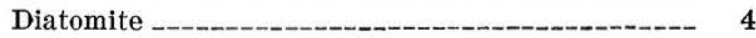

Yellow tuff

Diatomite -.-_-_- 5

Yellow tuff

Diatomite (sample T2)

Ash and diatomite -

Yellow tuff _-_-_-_-_-_- 3

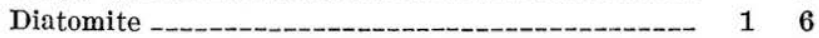

Yellow sandy ash _._._._- 1

Diatomite

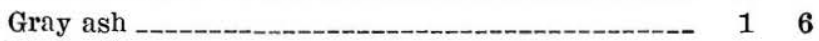

Diatomite -...-_-

Yellow tuff _-_- 1

Diatomite -_-_-_- 110

Gray ash _-_- 1

Diatomite -_-_-_-_-_-_ 110

Gray ash _-__-_ 1

Diatomite with thin partings_______- $82 / 3$

Gray ash _-_._- $1 / 3$

Diatomite (sample T1)

Alluvium. 
Section 2, on the east slope of the prominent hill in the $\mathrm{NW} 1 / 4$ sec. 5, T. 19 S., R. 41 E. The section is not detailed but was compiled from altimeter notes.

Summit.

Feet

Capping flow of light-gray rhyolite-_-_ 5

Unconformity.

Gray ash, loosely consolidated

Unconformity.

Diatomite in beds 1 to 5 feet thick with thin partings of loosely consolidated gray ash and occasional thicker beds of the same ash

Section 3, on claim 10 of the Pacific Coast Diatom Corporation, in the center of the $\mathrm{N} 1 / 2$ sec. 34 , T. 18 S., R. $41 \mathrm{E}$. The section was measured on the east face of the roughly conical hill. The quarry is in the lower part of the section.

Summit.

Ft. in.

Cap of light-gray rhyolite

Unconformity.

Diatomite of good quality, but obscured by hill wash (sample V4, 22 feet below top; sample V3, 75 feet below top)

Diatomite, ashy at base but decreasing in ash toward top_ 55

Unconformity.

Gray, loosely consolidated ash 82

Unconformity.

Diatomite in beds 1 to 3 feet thick. with ash partings__- 58

Detailed section:

Ft. in.

Clayey diatomite

1

Diatomite

Gray ash

Diatomite

Clayey diatomite

6-8

Diatomite 10

Clayey diatomite

$1 / 4-1 / 2$

Diatomite 35

Clayey diatomite $1 / 4-1 / 2$

Diatomite (sample V2)

Gray ash

Diatomite

27

Hard gray ash

Diatomite

Gray ash

Diatomite

Coarse gray ash

Diatomite; numerous ash seamg

Gray ash

Diatomite in 1- to 2 -foot beds; thin ash partings 


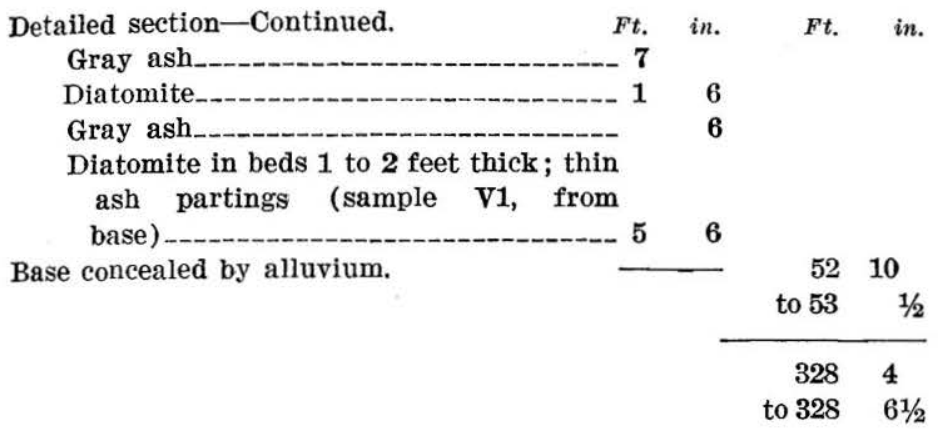

Section 4, on claims 5 and 6 of the Pacific Coast Diatom Corporation, in the NW1/4 sec. 2, T. 19 S., R. 41 E. Starting at the base of the hill, it extends in a southeasterly direction to the top.

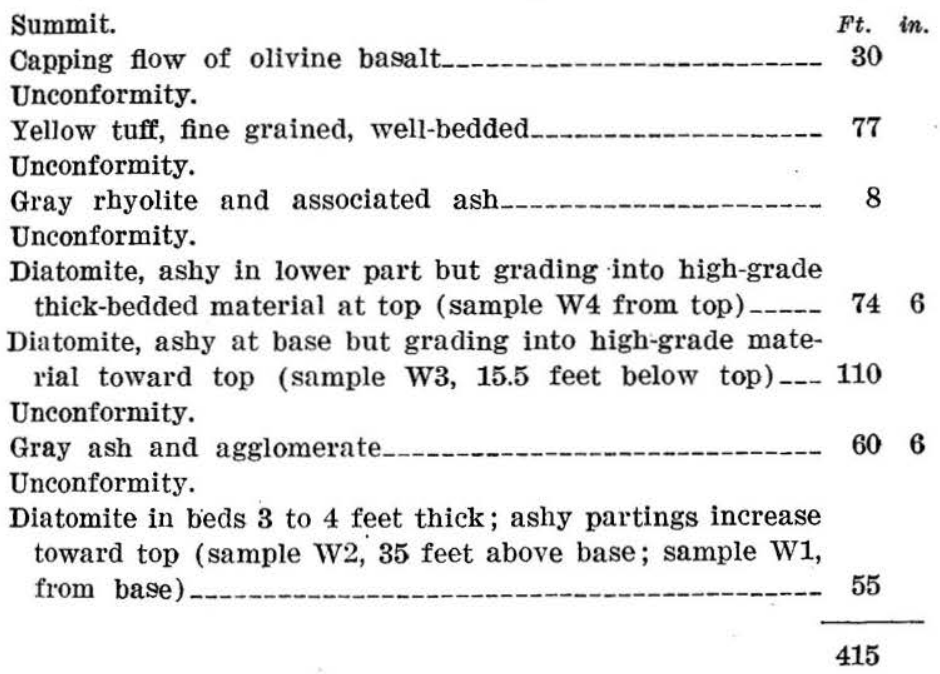

Section 5 , in the NE1 14 sec. 10 , T. 19 S., R. 41 E., on claim 3 of the Pacific Coast Diatom Corporation.

Summit.

Pumiceous agglomerate weathering to prominent pinnacles.

Unconformity.

Lower diatomite member: Ft. in. Ft. in.

Diatomite and thin-bedded ash

Diatomite with several thin ash seams_-_-_-_-- 5

Gray ash, loosely consolidated_-_- 6

Diatomite with several ash seams____.___._._. 6

Gray ash_..-_ $S$

Diatomite

Gray ash

Diatomite-_-_. 8

Gray ash

Diatomite (sample X8)

Gray ash 
Diatomite in beds 1 to 3 feet thick with sandy ash part- Ft. in. ings (sample X7, 41/2 feet above base) -...-...-...-

Loosely consolidated gray ash

Diatomite in beds 1 to 2 feet thick with thin sandy gray ash partings 1 to 3 inches thick (sample X6, 22 feet above base; sample X5, at base) -.-.-...-...--

Ashy diatomite with interbedded gray ash......-.-.---

Diatomite in beds 1 to 3 feet thick with gray ash partings 1 to 3 inches thick (sample X4, 831/2 feet above base; sample X3, 501/2 feet above base; sample X2, 6 feet above base)

Coarse gray sandy ash containing numerous pea-sized granules of diatomite and a few larger fragments, both silicified and unchanged

Section 6 , in the $\mathrm{NE} 1 / 4$ sec. 23 and the SE1/4 sec. 14, T. $19 \mathrm{~S}$, R. $41 \mathrm{E}$.

Agglomerate.

Gray ash

Unconformity.

Lower diatomite member:

Thin-bedded diatomite with many ash seams_-_-_--.-

Diatomite with few thin partings (sample S12, from base)

Diatomite with many ash seams_-_-_-_-_-_-_-_-

Detailed section:

Agglomerate

Fit. in.

Diatomite (sample S11)

Gray ash

Diatomite

Gray ash

Diatomite -

Gray ash _._. 3

Thin-bodied diatomite and ash

Diatomite -

Gray ash _-_-_- 6

Diatomite -

Ash and diatomite

Diatomite (sample S10)

Gray ash

Diatomite (sample S10)

Coarse-grained gray-green tuff with particles of pumice and diatomite. Grades upward into coarse sandy ash_Diatomite and ash seams (sample 59 , from base) -...-.

Gray ash in alternating coarse and fine beds_

Detailed section:

Gray ashy diatomite__

Gray ash -.-_- 4

Diatomite - -

Gray ash _...... 6 


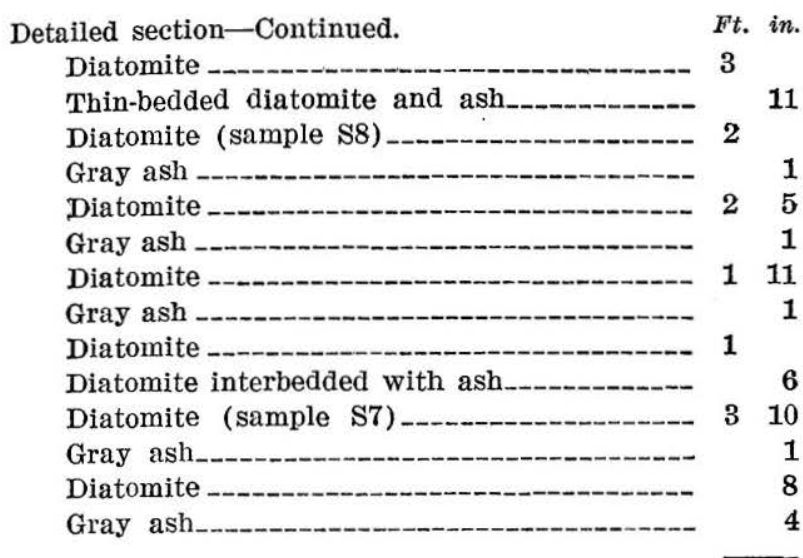

Diatomite in beds 6 to 18 inches thick with ash partings 4 inches thick

Coarse sandy ash

Diatomite in beds 1 to 4 feet thick with gray ash partings not over 6 inches thick (sample S6, 96 feet above base; sample S5, 93 feet 6 inches above base; sample S4, 38 feet 6 inches above base; sample S3, 33 feet above base; sample $\mathrm{S} 2,22$ feet above base; sample $\mathrm{S} 1,11$ feet above base)
2211

\begin{tabular}{cc}
99 & 6 \\
\hline 385 & 9
\end{tabular}

Section 7, in the SE $1 / 4 \mathrm{SE} 1 / 4$ sec. 22 , T. 19 S., R. 42 E. Measured from the basalt cap rock down through the pinnacle beds of the gray ash member.

Summit.

Olivine basalt (capping lava flows).

Unconformity.

Yellow tuffs.

Unconformity.

Upper diatomite member: $\quad F^{\prime} t$. in.

Diatomite and gray ash, silicified in part_-.- 60

Diatomite, massively bedded, few partings_ 10

Gray sandy ash

Diatomite, massively bedded, few partings_ 7

Gray sandy ash

Diatomite, massively bedded (sample P1) _- 10

Yellow clayey ash._-__-_ 11

Diatomite, massive, no partings___________ 26

Gray sandy ash_._- 1

Yellow clayey ash___-_-_-_-_-_-_-_ $\quad 10$

Diatomite, massive, no partings___._-___-_-_ 66

Yellow clayey diatomite______._._._. 6

Diatomite, massive, no partings (sample

P2)

Gray sandy ash

Diatomite, massive, no parting

Gray sandy ash 
Upper diatomite member-Continued.

Diatomite, massive, no partings

Ft. in

18

Gray sandy ash

Diatomite, massive, no partings

Gray sandy ash

Impure clayey diatomite-_-

Diatomite, massive, no partings

Gray sandy ash.--

Diatomite, massive, no partings_._-_._-_.-_

Coarse yellow ash

Thin-bedded ash and diatomite_._-_-_-_-_ 2

Diatomite, massive, few partings_-_-_-_-_-- 26

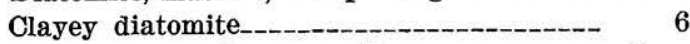

Diatomite, massive, no partings___._______-_ 9

Yellow ferruginous diatomite-_-_-_-_-_-- 6

Diatomite, massive, no partings (sample P3)

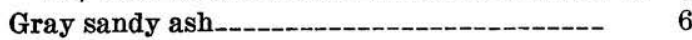

Diatomite, massive, no partings_____-__-_ 106

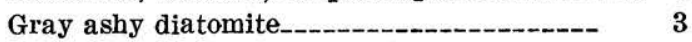

Diatomite, massive, no partings___-_-_-_-_ 126

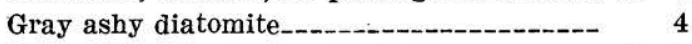

Diatomite, massive, no partings_____-_-_-_ 56

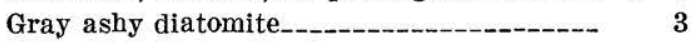

Diatomite, massive, no partings________-_ 18

Yellow ferruginous diatomite___-_-_-_-_ 1

Diatomite, massive, no partings________._ 5

Shaly ash._...-...- 1/4

Diatomite, massive, no partings (sample P4)

56

Brown ash

Diatomite, massive

Yellow ash

Diatomite, massive, no partings_._._-_._- 3

Ashy diatomite_-_. $11 / 2$

Diatomite, massive, no partings___-_-_-_ 26

Ashy diatomite_._. 1

Diatomite, massive, no partings____-_ 46

Yellow ash_._-_. $1 / 2$

Diatomite, massive, no partings

Yellow ash._.

Diatomite, massive, no partings _........... 3

Yellowish-green ash....

Diatomite, massive, no partings_._._._._._ 3

Unconformity.

Gray ash member: Gray ash with an unevenly bedded agglomerate weathering to prominent pinnacles in central part of member

Unconformity.

Lower diatomite: Thick-bedded diatomite with thin ashy partings (sample P5, 10 feet below top; sample P6, 30 feet below top

Base of section. 
Section 8 , in the gully in the extreme southwest corner of sec. 23 and northwest corner of sec. 26, T. 19 S., R. 42 E. (See pl. 8.) Part of it lies in claim E of the Pacific Coast Diatom Corporation.

Olivine basalt (capping flows).

Unconformity.

Yellow tuff member: Fine-grained well-bedded tuffs and clays with thin partings of sandy gray ash_._-_-_-_-_Unconformity.

Upper diatomite member:

Diatomite in beds 1 to 4 feet thick with thin ash partings (sample Q8, 15 feet above base)

Diatomite, massive, no partings

Gray sandy ash--

Diatomite, massive, no partings........-..-

Gray sandy ash

Diatomite, massive-1-

Gray sandy ash

Diatomite, massive-1-.--

Gray sandy ash_-_-__-_-_

Diatomite, massive_-_...-_-_-

Gray sandy ash.--

Diatomite, massive (sample Q7) --_.-------

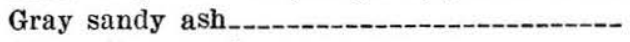

Diatomite, massive-_-_-_-_-_-_-_---

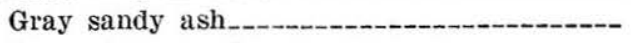

Diatomite, massive
Interbedded ash and diatomite.-...-

Interbedded ash and diatomite-_.--
Diatomite, massive

Gray sandy ash_-_-_-_-_-_-

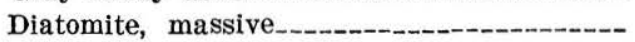

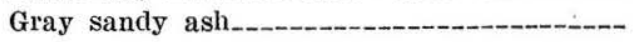

Diatomite, massive_-_-_-_-_-_-_-_-_-_

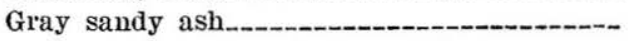

Diatomite, massive (sample Q6) --.--------

Gray sandy ash_-_-_-_-_-_-

Diatomite, massive

Gray sandy ash

Diatomite, massive-_-_-_-_-_-_-

Gray sandy ash

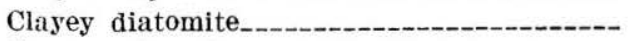

Gray sandy ash

Diatomite, massive

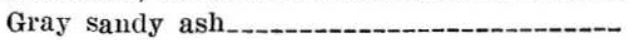

Diatomite, massive

Gray sandy ash.--_.-.

Diatomite, massive_..- 4

Gray sandy ash._- 3

Diatomite, massive-_- 55

Gray sandy ash.

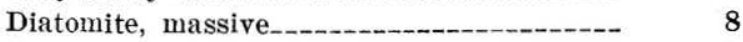

Gray sandy ash_-_._- 2

Ft. 


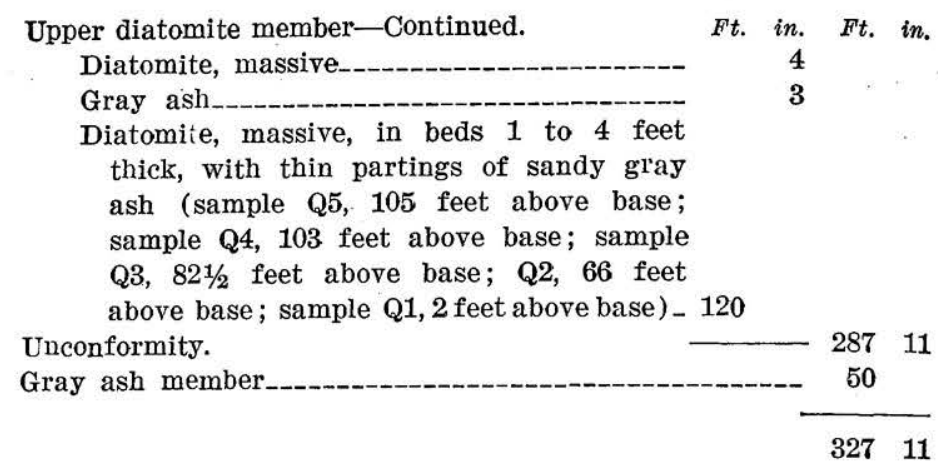

Section 9 , in the bluff on the south side of Malheur River in the SE1/4 sec. 34, T. 19 S., R. 42 E. (See pl. 8.) This section is not on the Pacific Coast Diatom Corporation's claims, though a few test pits are located on the outcrops.

Olivine basalt (capping lava flows).

Unconformity.

Yellow tuff member:

Fine-grained well-bedded yellow tuff with occasional diatomite seams.

Ft. in. Ft. in.

Coarse-grained yellow agglomerate

Gray sandy ash._-_-_-_-_-_-_-_-_-_-_- 13

Impure diatomite with ash seams_-_-_-_-_- 18

Coarse gray sandy ash

Earthy diatomite (sample U5) -..._...-.- 1

Thin-bedded sandy yellow tuff with thin diatomite seams

Unconformity.

Upper diatomite member:

$\begin{array}{llll}\text { Thin-bedded diatomite-_-_-_-_-_-_-_-_-- } & \mathbf{1} & \mathbf{6}\end{array}$

Yellow and gray ash, interbedded
Diatomite, good quality, in beds 4 to 10 feet thick separated by ash partings (sample U4, 56 feet above base; sample U3, 3 feet above base)

Gray sandy ash

Diatomite in beds 4 to 10 feet thick with thin ash partings (sample U2, 161/2 feet above base)

Gray sandy ash

Diatomite in beds 1 to 4 feet thick with thin ash partings (sample U1, 111/2 feet above base)

Diatomite, extensively silicified

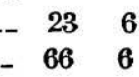


In these sections the alternation of volcanic ash or dust and diatomite is well shown. This feature is a very striking characteristic of the deposits of this region. The loose sandy volcanic ash is in marked contrast to the massive diatomite. The contacts between the two materials are usually sharp, no gradation being apparent. In many places there is an apparent rhythmical alternation, the thicknesses of the diatomite beds being of the same order of magnitude, and the partings of ash of nearly uniform thickness. Although the individual beds have never been traced more than a few hundred feet, the sharp boundaries and the uniform thickness where they have been observed suggest that in very detailed work such as should be carried out by companies interested in developing the deposits, these beds might be traced for considerable distances.

These sections suggest that the diatomite was formed in a relatively quiet body of water into which practically no streams drained, and which was undisturbed except for occasional ash showers. Of particular interest is the massive character of the diatomite. Even in the 10-foot beds this massive nature is preserved with no trace of lamination. Here and there false bedding may be observed on weathered outcrops, owing to exfoliation or spalling parallel to the exposed surface, and in a few places some of the very ashy beds are shaly. The diatomite is generally very pure, with but little volcanic ash or clay present. Both the absence of lamination and the purity indicate deposition of diatomaceous material without accompanying deposition of sediment by tributary streams. Similarly the sharp boundaries and the incoherent nature of the partings of volcanic dust suggest that this material was deposited during brief showers of ash without opportunity for noticeable admixture of the contemporaneous diatom floras.

\section{QUALITY}

The diatomite of this district is noteworthy for its high purity, its brilliant white color, its remarkable toughness, and its low apparent density. The better grades of it form more than half of the total in each measured section and have a general appearance in the hand specimen of brilliant white plaster or chalk. Toughness and freedom from lamination are combined with other desirable qualities to make the Harper earth of particular interest to the manufacturer or user of sawed natural blocks, bricks, and other forms.

Color and weight.-The samples collected during the measurement of the various sections have been examined for color and weight, and the results are tabulated on pages 108-111. No attempt was made to sample systematically, and the samples collected therefore do not furnish a basis for estimation of the amounts of diatomite of different qualities. 
Toughness or strength.-No official tests of the strength of the Harper diatomite have been made. Its toughness, however, is quite apparent even to the casual observer in the field. The results of tests made for the old American Diato Co. in 1918 by the Smith-Emery Co., of Los Angeles, Calif., are given here through the courtesy of Mr. W. G. Morgan, of the Pacific Coast Diatom Corporation of Harper.

\section{Crushing strength of Harper diatomite}

[Smith-Emery Co.'s laboratory no. 23720A]

\begin{tabular}{|c|c|c|c|c|}
\hline Mark 1 & Dimensions (inches) & $\begin{array}{c}\text { Area } \\
\text { (square } \\
\text { inch) }\end{array}$ & $\begin{array}{c}\text { Maxi- } \\
\text { mum load } \\
\text { (pounds) }\end{array}$ & $\begin{array}{l}\text { Crushing } \\
\text { strength } \\
\text { (pounds } \\
\text { per } \\
\text { squars } \\
\text { inch) }\end{array}$ \\
\hline $\begin{array}{l}\text { No. } 1 \text {. } \\
\text { No. } 2 \text { (2) } \\
\text { No. } 3\end{array}$ & $\begin{array}{l}6.2 \text { by } 5.1 \text { by } 3 \\
9.2 \text { by } 6.0 \text { by } 3.0 \text { by } 6.0 \text { by } 3 .\end{array}$ & $\begin{array}{l}31.6 \\
55.2 \\
48.0\end{array}$ & $\begin{array}{l}15,850 \\
27,700 \\
27,300\end{array}$ & $\begin{array}{l}502 \\
520 \\
569\end{array}$ \\
\hline
\end{tabular}

1 These samples were taken from a quarry on claim 10 and correspond to my sample V2 (section 3).

Chemical analyses.-Chemical analyses of seven of the diatomito samples from Harper have been made in the laboratory of the Geological Survey with the same precision employed in rock analysis.

\section{Analyses of Harper diatomites}

[E. Theodore Erickson, analyst]

\begin{tabular}{|c|c|c|c|c|c|c|c|}
\hline & S7 & $\mathrm{T} 3$ & U4 & V2 & W4 & $\mathrm{X} 8$ & P4 \\
\hline \multirow[t]{2}{*}{$\begin{array}{l}\mathrm{SiO}_{2} \\
\mathrm{TiO}_{2} \\
\mathrm{Fe}_{2} \mathrm{O}_{32} \\
\mathrm{Al}_{2} \mathrm{O}_{3} \\
\mathrm{CaO} \mathrm{O}_{2} \\
\mathrm{MgO} \mathrm{N}_{2} \\
\mathrm{Na}_{2} \mathrm{O}_{2} \\
\mathrm{SO}_{3} \mathrm{O}_{3} \\
\mathrm{Cl}\end{array}$} & $\begin{array}{r}77.96 \\
.27 \\
2.92 \\
3.93 \\
1.26 \\
.67 \\
.98 \\
.16 \\
.15 \\
.02 \\
.15\end{array}$ & $\begin{array}{r}83.82 \\
.19 \\
1.99 \\
3.74 \\
.58 \\
.30 \\
.34 \\
.20 \\
.10 \\
\text { None } \\
.09\end{array}$ & $\begin{array}{r}74.78 \\
.27 \\
1.98 \\
6.69 \\
.88 \\
.65 \\
1.44 \\
.32 \\
.88 \\
1.66 \\
.13\end{array}$ & $\begin{array}{r}82.64 \\
.18 \\
1.88 \\
3.20 \\
.64 \\
.38 \\
.04 \\
.14 \\
.06 \\
\text { None } \\
.09\end{array}$ & $\begin{array}{r}85.52 \\
.14 \\
1.04 \\
2.60 \\
.48 \\
.17 \\
.28 \\
.04 \\
.09 \\
\text { None } \\
.14\end{array}$ & $\begin{array}{r}78.12 \\
.33 \\
1.88 \\
6.29 \\
.96 \\
.41 \\
.34 \\
.20 \\
.04 \\
\text { None } \\
.13\end{array}$ & $\begin{array}{r}82.84 \\
.18 \\
1.14 \\
3.18 \\
.38 \\
.23 \\
1.12 \\
.14 \\
.69 \\
.18 \\
.05\end{array}$ \\
\hline & 88.42 & 91.37 & 89.68 & 89.25 & 90.50 & 88.70 & 90.13 \\
\hline
\end{tabular}

These analyses have been recomputed to a water-free basis in the table on page 114.

Microscopic analyses.-Material from the same seven samples of which chemical analyses were made was submitted to Kenneth E. Lohman, of the Geological Survey, who furnished the following notes and also the accompanying photomicrographs.

Sample 1021, Harper district, Malheur County, Oreg., sec. 14, T. 19 S., R. 41 E.; B. N. Moore, no. S7 (pl. $7 ; C)$.

Practically all the visible fines in this sample consist of minute fragments of diatoms. The range in size is very slight, from a maximum diameter of 0.017 millimeter for the most abundant form to a minimum diameter of 
0.006 millimeter for a common form. Fragments, making up some 20 percent, vary in size from 0.001 to 0.010 millimeter. The diatoms are quite clean.

The principal species of diatoms are the following:

Melosira distans var. lyrata (Ehrenberg) Bethge. Abundant.

Melosira granulata (Ehrenberg) Ralfs. Abundant.

Melosira granulata var. spiralis Grunow. Abundant.

Melosira granulata var. curvata Grunow. Common.

Navicula scutelloides Wm. Smith. Rare.

Tetracyclus ellipticus (Ehrenberg) Grunow. Rare.

Sample 1022, Harper district, Malheur County, Oreg., sec. 15, T. 18 S., R. 41 E.; B. N. Moore, no. T3 (pl. $7, D$ ).

Very slight amounts of clay and volcanic ash are present, the balance of the fines being fragments of cliatoms: This material is exceptionally uniform in size, over 90 percent of the diatoms belonging to one species, Melosira gramulata var. curvata, with an average diameter of 0.004 millimeter and an average length of 0.014 millimeter. The largest form present, Coscinodiscus sp. $a$ (making up about 4 or 5 percent) has a maximum diameter of 0.050 millimeter. Broken diatoms constitute between 10 and 20 percent of the material. The diatoms are quite clean.

The principal species of diatoms are these:

Melosira granulata var. currata Grunow. Dominant.

Coscinodiscus sp. Few.

Melosira distans var. laevissima Grunow. Few.

Melosira granulata (Ehrenberg) Ralfs. Rare.

Melosira granulata var. spiralis Grunow. Rare.

Melosira arenaria Moore. Few.

Fragilaria pinnata Ehrenberg. Few.

Tetracyclus lacustris Ralfs. Rare.

Tetracyclus ellipticus (Ehrenberg) Grunow. Rare.

Tetracyclus ellipticus var. clypeus (Ehrenberg). Rare.

Tetracyclus ellipticus var. linearis (Ehrenberg). Rare.

Sample 1023, Harper district, Malheur County, Oreg., sec. 34, T. 19 S., R. 42 E.; B. N. Moore, no. U4 (pl. 7, $E$ ).

This sample represents rather poor diatomite, being high in fines, composed of minute fragments of diatoms, clay, volcanic ash, and some organic matter. As can be seen by reference to the plate, these fines constitute the bulk of the material, so that its economic use would seem to be limited to incorporation with a cement aggregate as an admixture. The range in size of the material is from a maximum diameter of 0.02 millimeter down to colloidal. The diatoms are fairly dirty, from contamination with the clay and organic material present.

The following are the principal species of diatoms:

Melosira granulata (Ehrenberg) Ralfs. Dominant.

Coscinodiseus sp. Common.

Melosira granulata var. curvata Grunow. Few.

Tetracyclus ellipticus (Ehrenberg) Grunow. Rare.

Sample 1024, Harper district, Malheur County, Oreg., sec. 34, T. 18 S., R. 41 E.; B. N. Moore, no. V2 (pl. $7, F)$.

This sample is very pure, being low in fines and other visible impurities, except for small amounts of volcanic ash. The diatoms forming this material

$63952-37-7$ 


\section{PLATE 10}

A. Sample W4 from Harper district, Malheur County.

1. Melosira distans var. laevissima Grunow.

2. Melosira granulata (Ehrenberg) Ralfs.

B. Sample X8 from Harper district, Malheur County.

1. Cyclotella sp. a.

2. Melosira distans var. lyrata (Ehrenberg) Bethge.

o. Sample P4 from Harper district, Malheur County.

1. Melosira crenulata var. valida Grunow.

2. Melosira granulata (Ehrenberg) Ralfs.

D. Sample 91 from Otis Basin, Harney County.

1. Melosira granulata (Ehrenberg) Ralfs, narrow variety.

2. Melosira italica Kützing.

E. Sample Z4 from Otis Basin, Harney County.

1. Coscinodiscus 'subtilis Ehrenberg.

2. Melosira granulata (Ehrenberg) Ralfs.

F. Sample Z10 from Otis Basin, Harney County.

1. Coscinodiscus subtilis Ehrenberg.

2. Melosira granulata (Ehrenberg) Ralfs. 

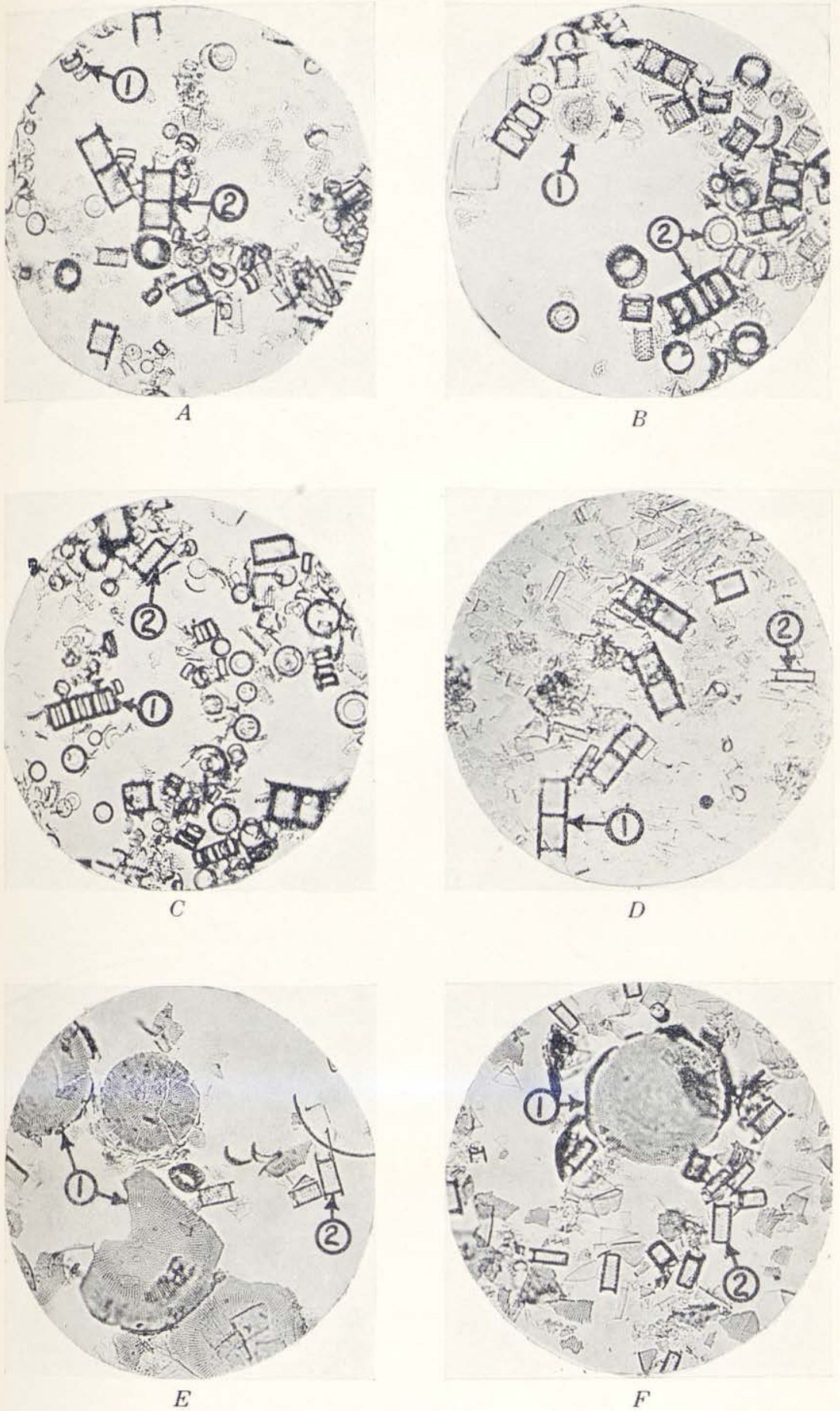

PHOTOMICROGRAPHS OF STREWN MOUNTS OF UNCLEANED DIATOMITE OF EASTERN OREGON.

Enlarged 300 diameters. Photographed by K. E. Lohman. 
are nearly all of one size, with maximum dimensions varying between 0.004 and 0.012 millimeter, although approximately 10 percent of the Melosiras occur in chains having lengths up to 0.06 millimeter. Less than 5 percent of the diatoms are broken, and thus the material is very clean.

The principal species of diatoms are as follows:

Melosira distans var. lyrata (Ehrenberg) Bethge. Dominant.

Melosira granulata var. curvata Grunow. Common.

Tetracyclus ellipticus (Ehrenberg) Grunow. Few.

Coscinodiscus sp. Rare.

Fragilaria pinnata Ehrenberg. Rare.

Melosira arenaria Moore. Rare.

Navicula scutelloides Wm. Smith. Rare.

Tetracyclus rostratus Hustedt. Rare.

Total number of species, 14.

Sample 1025, Harper district, Malheur County, Oreg., sec. 2, T. 19 S., R. 41 E. ; B. N. Moore, no. W4 (pl. 10, A).

Except for small amounts of volcanic ash, the fines in this sample are composed entirely of minute fragments of diatoms. The range in size of the diatoms is small, from 0.003 to 0.015 millimeter in diameter, although a few of the Melosiras occur in chains with a maximum length of 0.04 millimeter. Approximately 5 percent of the diatoms are broken, but many of the fragments are larger than the smaller diatoms. The diatoms are very clean.

The principal species of diatoms are the following:

-Melosira crenulata var. valida Grunow. Abundant.

Melosira granulata (Ehrenberg) Ralfs. Abundant.

Melosira distans var. laevissima Grunow. Abundant.

Melosira granulata var. curvata Grunow. Common.

Cymbella ventricosa Kützing. Rare.

Sample 1026, Harper district, Malheur County, Oreg., sec. 11, T. 19 S., R. 41 E. ; B. N. Moore, no. X8 (pl. 10, B).

The only visible impurities in this sample are small amounts of volcanic ash and very small amounts of clay. The range of sizes of the diatoms is small, 95 percent of the material having a maximum diameter of 0.015 millimeter and a maximum length of 0.028 millimeter. The maximum dimension of one rare form attained 0.025 millimeter. Very few of the diatoms are broken, except a few of the more fragile forms, resulting in a clean material. The individual diatoms are also fairly clean.

The following are the principal species of diatoms:

Melosira distans var. lyrata (Ehrenberg) Bethge. Dominant.
Cyclotella sp. a. Common.
Melosira granulata var. curvata Grunow. Common.
Fragilaria pinnata Fhrenberg. Few.
Melosira granulata (Ehrenberg) Ralfs. Few.
Tetracyclus ellipticus Ralfs. Few.

Total number of species, 15.

Sample 1027, Harper district, Malheur County, Oreg., sec. 22, T. 19 S., R. 42 E. ; B. N. Moore, no. P4 (pl. 10, C).

The sample is exceptionally pure, having very few visible impurities. The range of sizes of the diatoms is slight, 95 percent falling between 0.023 and 0.008 millimeter. Very few of the diatoms are broken, probably less than 5 per- 
cent. In addition to this, the individual diatoms are very clean, making it an ideal diatomite for many purposes.

The princinal snecies of diatoms are as follows:

Melosira crenulata var. valida Grunow. Abundant. Melosira granulata (Ehrenberg) Ralfs. Abundant. Melosira granulata var. Few.

Melosira arenaria Moore. Rare.

\section{UTILIZATION}

Diatomite of varying degrees of purity is present in the Harper district in large amount, and the purer material, which constitutes a large fraction of the total quantity present, should be eminently suitable for many uses. The Pacific Coast Diatom Corporation, which operated in this district up to 1934, sold milled diatomite for use as cement admixture, as insulation material, and in filtration. The purest grades appear to be well suited for fillers for such things as hard-rubber battery boxes, a use which accounts for more than 10,000 tons of the United States production of diatomite a year. For insulation and for concrete admixture the material from this district is well suited. The city of Portland, the Oregon State Highway Commission, and the United States Bureau of Reclamation have used Harper diatomite in various concrete structures. In the field of sawed shapes the Harper earth should enjoy considerable popularity because of its high crushing strength and its toughness. In the field of filtration considerable prejudice exists against the finer diatomite, but material from the Harper district has been used for this purpose.

\section{DEVELOPMENT}

History.-The history of diatomite development in the Harper district began in 1910, when, according to local accounts, a German physician, familiar with kieselguhr, recognized the potentialities of the district. A "rattler", similar to a foundry rattler, was set up on what was claim 8 of the Pacific Coast Diatom Corporation. Diatomite was quarried, air-dried, and reduced to powder in the rattler. In all, several carloads were produced, which were staged out from Westfall to the railroad. The German died, and interest waned. The only remaining trace of the enterprise is the rattler.

With the building of the branch railway into this region interest was again aroused, and in 1917 the American Diato Co. was formed. This company had several investigations made of its material and opened up quarries on its claims 3 and 10 . The present mill was built, and numerous shipments of filtration, admixture, and insulation materials were made. Mr. Doernbecher, a prominent lumberman of Portland, became interested in the company, but his death in 1919 proved a blow from which the company never recovered. 
In 1923 the struggling company was taken over by W. G. Morgan, of Portland, who added other claims to those of the old American Diato Co. The new company was known as the Whiteurth Products Co. and had its offices at Harper. In 1927 the Whiteurth Products Co. was incorporated under the laws of Oregon as the Whiteurth Corporation. The stock was taken by locally interested persons, no selling campaign being initiated. Certain difficulties in the organization were encountered, and early in 1931 the name was changed to Pacific Coast Diatom Corporation by the filing of supplementary articles with the State Corporation Commission. In 1933 the corporation was dissolved and possession of the properties passed to $\mathrm{W}$. G. Morgan. ${ }^{40 a}$

Claims embrace $81 / 2$ sections, as shown in figure 7 . The original claims of the old American Diato Co. are nos. 1 to 10. Nos. 11 to 15 and $\mathrm{A}$ to $\mathrm{Y}$ were added by the Whiteurth Co.

The claims formerly owned by the Pacific Coast Diatom Corporation are shown in figure 7 .

Development.-Work done so far in the district has been largely exploratory. Sizable pits and small quarries have been opened on all claims, and several roads constructed. A large quarry has been opened on claim 10 and also one on claim 3. Up to September 17, $1931, \$ 147,291.41$ had been spent by the corporation on development work, of which $\$ 67,450$ represented fixed assets, such as the mill, offices, and land.

Quarry 3 is in the south end of claim 3 in a medium-tough, white, massively bedded diatomite of fine grade. The strata mined occur on the edge of a ridge and are from 3 to 5 feet thick. They lie nearly flat and are mined by working into the side of the ridge and stripping. Formerly, the diatomite, after drying in the open stacks, was loaded into a car and dumped into bins at the head of a gulch 200 feet below, on the southwest side. From these bins it was trucked to the mill. In 1931 a new road was constructed from the east, allowing the trucks to drive into the quarry and be loaded directly.

Quarry 10 is in the center of claim 10 , about 8 miles by the Westfall Market road from Harper. It is about a quarter of a mile north of the road, on the lower part of the east slope of a roughly conical hill. As shown in plate $9, B$, a face several hundred feet long and 5 to 15 feet high has been opened which exposes several beds of massive, pure-white, light-weight, and very tough diatomite. These beds are from $2 \frac{1}{2}$ to 3 feet thick and are separated by thin ashy partings.

\footnotetext{
${ }^{40 a}$ According to information from the U. S. Bureau of Mines the Pacific Const Silica Corporation has succeeded the Whiteurth Co., and W. G. Morgan has formed the National Diato Co.
} 
The soil, which is only about 6 inches thick, was stripped away and the diatomite mined by powder and pick. The blocks obtained were stacked in high, narrow open piles and allowed to dry. According to corporation reports, the material as quarried contains 12 percent of moisture, which is reduced to 2 to 5 percent by air-drying. A short drift follows the beds 20 feet into the face. No quarrying has been done recently, all the material milled being taken from old stocks.

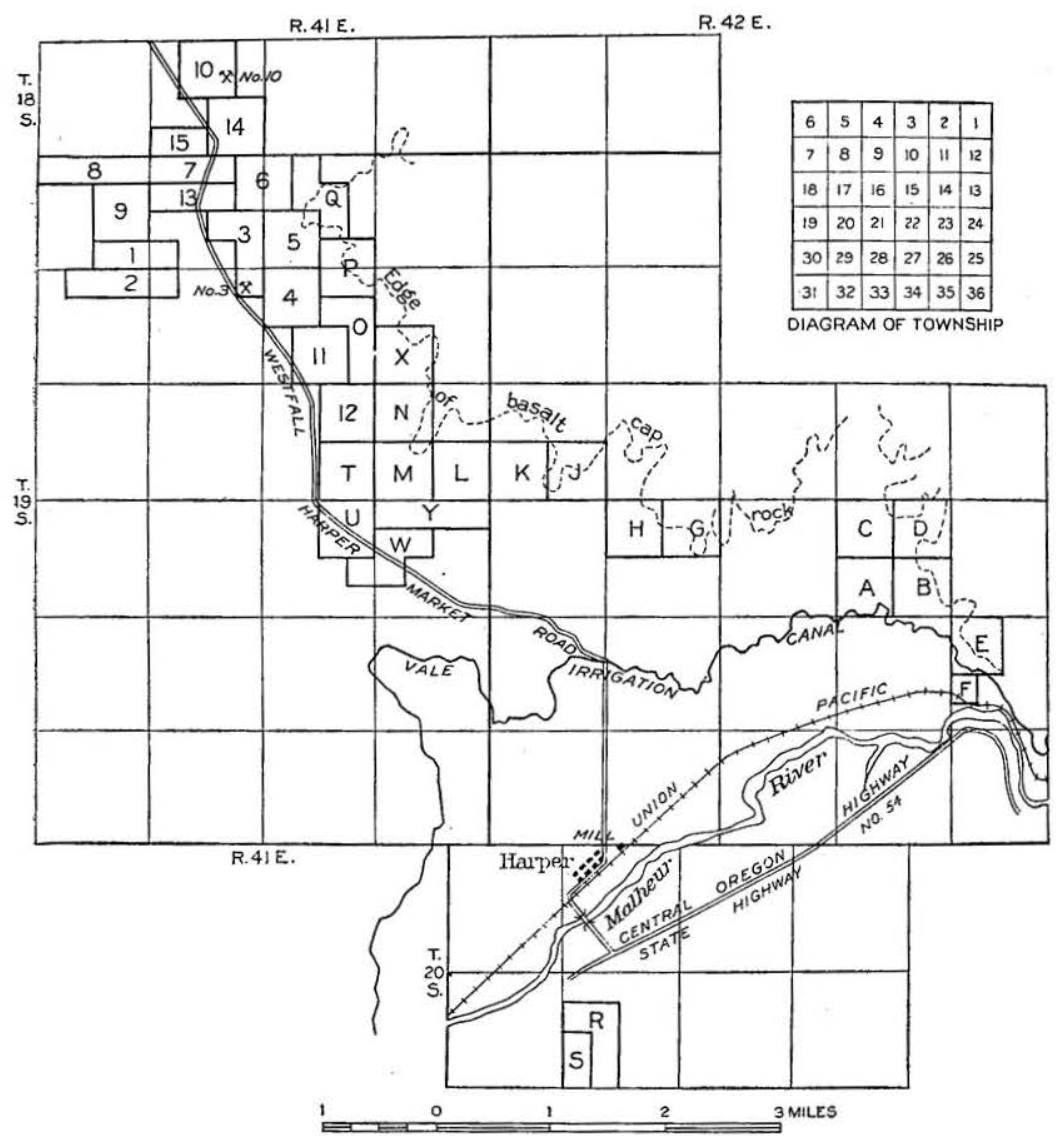

Figure 7.-Map showing location of diatomite claims near Harper, Malheur County.

The present mill is at Harper, on a branch of the Oregon Short line, having been so built as to allow the construction of a spur track. At present time a loading platform allows the loading of products on cars on the Harper siding. The mill is a wooden building 49 by 96 feet in floor dimensions. Water is supplied from a well, and power by a semi-Diesel engine. The diatomite brought from the quarries is dumped into a bin from which it is passed through spiked rolls and raised by a bucket elevator 60 feet to the storage bins. From these bins the material flows to the "Durite" and "Dis- 
ilo" mills. The Durite mill reduces the small lumps to suitable size for use in insulation by means of a pair of grooved rolls. The Disilo mill, which prepares the finely divided material for use in admixture and filtration, consists of a remodeled Raymond No. 000 mill and separator and has a capacity of about 5 tons of minus 200mesh product every 10 hours. The material is bagged by hand and stored in the mill.

Besides the above-mentioned equipment there is a practically new no. 1 Raymond mill and separator that has been set up but never used, and a 125-horsepower steam engine and boiler which has not been set up.

Products.-The Pacific Coast Diatom Corporation listed the following milled diatomite products in its trade literature:

Disilo, for admixture.

Durite, for insulation.

Disilite, for foundry use.

Silicite, for high-temperature insulation.

Silite, for polishes, fillers, etc.

Diato brick, natural sawed shapes.

Silico brick, pressed brick.

Diato, mine run.

Reserves.-No accurate estimate can be given of the size of the reserves. The problem of what constitutes minable diatomite must first be solved, but it can be stated with assurance that sufficient diatomite of good quality is available here to sustain large-scale operations for a long time. A minimum estimate based on 6 feet of minable material distributed over the $81 / 2$ sections controlled by W. G. Morgan would give more than $50,000,000$ cubic yards of diatomite-enough to supply 100,000 tons a year for about 150 years.

\section{OTIS BASIN DIATOMITE}

\section{LOCATION}

The area embraced in the Otis Basin diatomite district covers about 65 square miles on the upper part of Otis Creek, 7 miles northeast of Drewsey, in northeastern Harney County. Otis Creek is part of the Malheur River drainage system and flows nearly parallel to the north fork of that river. Beulah, Juntura, and Drewsey are all within short distances of the area.

\section{INVESTIGATIONS}

So far as known, the only reference to the Otis Basin in the geologic literature of North America is that by Russell. ${ }^{41}$ Though cor-

\footnotetext{
${ }^{41}$ Russell, I. C., Preliminary report on artesian basins in southwestern Idaho and southeastern Oregon: U. S. Geol. Survey Water-Supply Paper 78, pp. 37-38, 1902.
} 
rect in his prediction of artesian water in the basin, Russell mistook the diatomite for a fine white volcanic dust.

The present report is based on a week's work by R. W. Richards and me in 1930 and an additional week by me in 1931. Though the work was of reconnaissance type, it is believed to have been suff. cient for present purposes. More detailed work would be a desir. able preliminary to any proposed exploitation.

Mr. Albert Altnow, a resident of the region, lent valuable assist. ance to the party in both seasons. His courtesies are here gratefully acknowledged, as are those of Mr. H. A. Miller, of Bend, who is actively interested in the diatomite.

\section{TOPOGRAPHY}

Otis Basin proper is roughly a triangle with its base at the north. ern margin of the area, which is part of the dissected south slope of the Ochoco or Strawberry Range. The two sides closing toward the south suggest the apex in that direction. The west side is a high, steep slope, capped with lava. The east side is much less steep and toward the apex has a break through which flows a tributary to Otis Creek from a smaller basin to the east. This smaller basin is separated from the north fork of the Malheur River by a long lavacapped ridge running in a northerly direction. Both basins are shown on plate 11 .

The lowest point in the main basin has an altitude of slightly more than 3,500 feet. The high points on the surrounding walls range from 4,500 to 5,300 feet. With the exception of the steep western wall, most of the slopes are comparatively gentle, except where soft, unresistant beds are covered or capped with resistant rocks such as lavas.

The middle portion of the basin is flat and suitable for farming. This land is adequately watered by artesian wells and by Otis Creek. There is scarcely more than 4 square miles of it, however, and the terraces of the valley are too high above the creek to be irrigated. Scattered around the edges of the basin are hills and spurs, some of them remnants of older stream terraces, and others formed of resistant lava stocks such as Hald Butte.

This report discusses both the larger and the smaller basins mentioned.

\section{ACCESSIBILITY}

Roads to five points lead out of Otis Basin, through Drewsey west to Harney and Burns, through Drewsey south to Riverside on the Oregon Short Line, south to Juntura on the Oregon Short Line, east through Beulah to Westfall, Harper, and Vale, and north to Prairio City. 
In the season of 1931-these roads were still narrow dirt roads which, in wet weather, were nearly or quite impassable. However, the route of the new Central Oregon Highway passes a few miles south of Drewsey, and by this route the distance from Otis Basin to Juntura is about 25 miles. At Juntura the branch railroad of the Oregon Short Line from Ontario to Burns has facilities for shipping.

\section{GEOLOGY}

The rocks of the Otis Basin extend from Miocene lava to recent alluvium. The diatomite, as in the Harper district, belongs to the Payette formation. With the exception of the diatomite, the rocks are of volcanic origin, including dikes and necks, lava flows, and water-sorted pyroclastic material. The distribution of these rocks is shown on plate 11, and the general relations of the formations are set forth in the following table:

Stratigraphic sequence in the Otis Basin

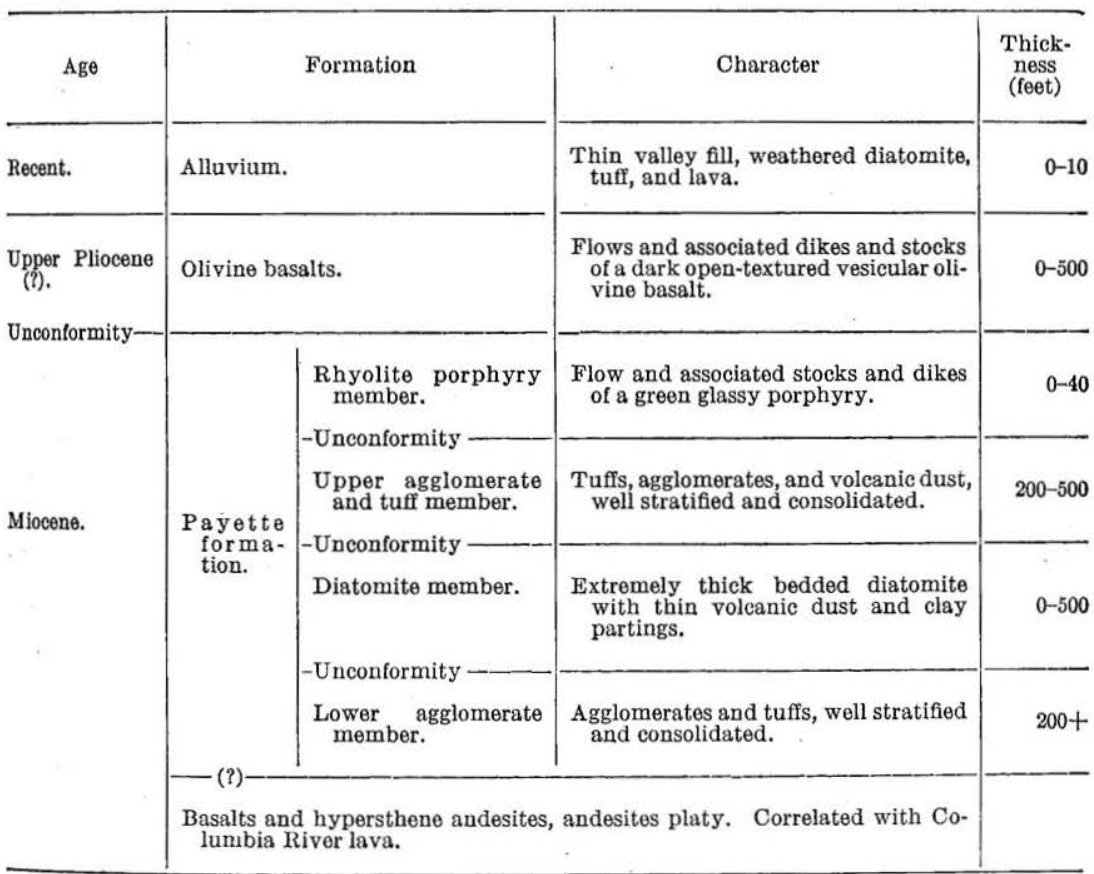

\section{TERTIARY DEPOSITS}

MIOCENE LAVA

The oldest rocks exposed in the Otis Basin diatomite district are Miocene lavas. These lavas, which may be traced into this region from the John Day Valley, occur north of the region mapped and 
form the south slope of the Ochoco Mountains. Against them the sediments of the Payette formation were deposited. Their relations to the overlying formations in this area are not definitely known.

PAYETTE FORMATION

The Payette formation is represented in the Otis Basin by a series of volcanic pyroclastic rocks and beds of diatomite. With the excep. tion of the fossil diatom floras, no fossils have been collected in this district, but Furlong ${ }^{42}$ has reported lower Pliocene vertebrate fossils in beds similar to the upper agglomerate and tuff member in the Stinking Water Basin, about 10 miles southwest of Drewsey. The fossil diatoms show differences on comparison with the Harper floras, but these differences may be assigned to differences in ecology as well as in time.

The Payette of the Otis Basin district is similar to that of the Harper district, resting upon Miocene lavas, containing in its upper part vertebrates identified as lower Pliocene, and being capped by the same series of Pliocene lavas. The individual members, however, cannot be traced from one district to the other, though they are similar lithologically.

Lower agglomerate member.-The lower agglomerate member of the Payette formation is well exposed in the hills north of Drewsey, where it consists of a well-bedded series of tuff and agglomerate. In secs. $14,15,22$, and 23, T. 19 S., R. 36 E., beds of this member occur in the core of an anticline, the continuation of which is shown by tuff beds in the southeast corner of sec. 4 and the southwest corner of sec. 3, T. 20 S., R. 36 E. Extensive outcrops occur in secs. 7 and 18, T. 20 S., R. 36 E., and in secs. 12 and 13, T. 20 S., R. 35 E.

This member of the Payette consists of thin-bedded agglomerato and tuff which weather to smooth round hills, marked in places by outcrops of some particularly resistant bed. The general color of the agglomerate ranges from a gray blue to an olive green. The tuffs are usually a tawny yellow. The bedding of these rocks is remarkably even, with a noticeable absence of cross-bedding. One of the most remarkable examples of uniformity of sorting is furnished by a specimen from the SE1/4 sec. 18, T. 20 S., R. 36 E. This rock is composed of alternating layers of fine lapilli and dust cemented to a hard impervious stone and coarser pea-sized lapilli coated with an earthy blue substance and cemented only at the contacts of the grains. The individual layers range from a quarter to half an inch in thickness and are continuous. The stone splits into flat slabs which are utilized in building stone sheds in the surrounding region.

2 Furlong, E. L., Distribution and description of skull remains of the Pliocene antelope Sphenophalos from the northern Great Basin province: Carnegie Inst. Washington Pub. 418, pp. $27-36,1931$. 
The relation of this member to the underlying Miocene lava is not known, as no exposures of the contact have been seen.

Diatomite member.-The diatomite in the Otis Basin has a maximum thickness of 500 feet. Its relation to the underlying agglomerate is unconformable, and outside of the basin it thins rapidly in all directions. To the west, in the vicinity of Drewsey, it thins out between the lower and upper agglomerate; to the north it thins out between the Miocene and later lavas; to the east it thins out and cannot be traced far beyond Beulah; and to the south it is missing in the region around Juntura. The diatomite of the Otis Basin is variable in appearance. Material of the highest quality is restricted to a small area in the central part of the basin, but the whole member is distinguished from other deposits by its thick beds and small number of beds of associated clay and volcanic dust. In sec. 34, T. 19 S., R. 36 E., one bed was measured which was 25 feet thick between partings.

The diatomite in this deposit was formed under rather quiet conditions, as shown by the small number of beds of volcanic ash. It may have been deposited in a lake not connected with the lakes in the Harper district, and perhaps because of slight differences in age or in alkalinity of the water the diatom floras are different. Whether the lake occupied a basin in the older agglomerates or whether the diatomite was formed in a constantly sinking lake basin is not known.

Upper agglomerate and tuff member.-Overlying the diatomite member in the Otis Basin is a series of yellow tuff and agglomerate beds which resemble the beds occupying a similar stratigraphic position at Harper. These sediments are thin-bedded tawny-yellow tuffs with which is interbedded much fine gray agglomerate. The thickness of the member is variable. None of these beds are left in the center of the basin, where the Pliocene basalts rest directly on the diatomite, but around the edges of the basin from 200 to 500 feet of them are preserved under the Pliocene lavas.

These yellow tuffs can be traced both south and west and cover considerable areas in the regions around Juntura and south of Drewsey.

Rhyolite porphyry member.-Overlying the yellow tuff member is a flow of grayish-green glassy rhyolite porphyry. This rock is closely related to stocks and dikes represented by hill 4809 , in sec. 19, T. 19 S., R. 37 E.; by Hald Butte, in sec. 26, T. 19 S., R. 36 E.; and by the small hill in sec. 36, T. 19 S., R. 36 E. The main portion of the flow is exposed in the cliffs just west of the district, but small blocks are common in the central part. The flow consists of a light gray-green porphyry with brilliant feldspar phenocrysts in a glassy groundmass. Under the microscope the rock is seen to consist of a few phenocrysts, largely sanidine with some quartz and an occasional andesine crystal, set in a glassy matrix. The ground- 
mass is fractured, and in the fractures small crystals of quartz have grown, forming small ellipsoidal bodies of diversely oriented crystals.

The rhyolite flow is clearly older than the overlying basalts but is separated from the rest of the Payette formation by an unconformity. Outcrops of a large stock of rhyolite porphyry identical with that of the Otis Basin occur on the north fork of the Malheur River halfway between Beulah and Juntura.

PLIOCENE OLIVINE BASALT

Overlying the rhyolites and lapping onto the Miocene lavas of the Ochoco Mountains is a series of basalt flows regarded as probably of upper Pliocene age. Their total thickness is not shown in any one exposure, as erosion has removed many of them. In the region south of Drewsey six flows may be counted lying above the rhyolite. Though it is quite probable that the number of flows and the thickness of the series was not constant over the entire region, the thickness of 600 feet represented in sec. 18, T. 19 S., R. 37 E., indicates that a considerable amount of lava once covered this region.

The flows are composed of an open-textured, finely crystalline, vesicular, heavy blue-black rock. A specimen examined under the microscope proved to be composed of labradorite, augite, and olivine intergrown in a diabasic texture. Minor amounts of magnetite were noted but no glass.

Related to the basalt flows are numerous stocks and dikes. The flows capping the hills in the central part of the basin are related to a series of dikes outcropping in secs. 2 and 3, T. 20 S., R. 36 E. The underground ramifications of these dikes to the south are indicated by extensive silicification of diatomite in secs. 10 and 11, T. $20 \mathrm{~S}$, R. $36 \mathrm{E}$. Other dikes occur in the long low hills forming the eastern boundary of the deposit. These hills are capped by flows, but below the flows there are many dikes, as shown in the canyons that cut through the hills.

\section{QUATERNARY DEPOSITS}

Quaternary deposits in the Otis Basin are limited to thin beds of alluvium and the hill wash. Except in a small area along Otis Creek the alluvium is not thick enough for farming. The alluvial cover on the hillsides is from 1 to 2 feet thick, sufficient to obscure most of the underlying rocks but not thick enough to interfere with mining.

\section{STRUCTURE}

The Otis Basin area contains two synclines and three anticlines. The two synclines include Otis Basin proper and the smaller eastern basin, and the anticlines form the east and west bounding ridges and 
the hills separating the two basins. These folds have a general northsouth trend. They are complicated by numerous igneous intrusions and by small faults.

FOLDS

The anticline along the western edge of the basin trends nearly $30^{\circ}$ east of south and strikes into the central anticline at the southern border of this area. The $\mathrm{V}$-shaped syncline between the two anticlines forms Otis Basin proper. Dips on both flanks of this syncline are usually low-rarely over $5^{\circ}$. The total vertical rise of the diatomite from the center of the basin to the western edge is not over 750 feet. An excellent exposure of the core of the central anticline may be had in secs. 14, 15, 22, and 23, T. 19 S., R. 36 E. Here erosion has exposed the lower agglomerate, which dips to the east and the west at angles of $25^{\circ}$. These same beds exposed in secs. 3 and 4 , T. 20 S., R. 36 E., lie nearly flat, though they form a continuation of the anticlinal structure. Dips in the western syncline are steep in the northern part amounting to as much as $20^{\circ}$ but in the southern part are gentle and under $10^{\circ}$. The anticline forming the eastern bounding ridge is greatly complicated by igneous intrusions.

As is shown by the Pliocene age of the basalts, these folds are of late Pliocene or Pleistocene age. They are considerably younger than the east-west folds of the Ochoco Mountains and are not related to any known system of folding.

FAULTS

Many small fractures have been noted in the diatomite of this district. Detailed mapping will probably reveal faults which in reconnaissance work have been overlooked. In connection with faults the presence of landslips, which are frequently mistaken for faulted blocks, must be mentioned. Numerous blocks of the capping lavas, both rhyolite and basalt, occur in the southwestern part of the area examined. The fact that the fractures limiting these blocks do not influence the underlying strata and the hummocky nature of their surfaces show them to be landslips. (See fig. 5.) The lava flows covering the high dividing ridge in the north-central part of the basin are badly broken, and some blocks have moved down the slopes nearly to stream level, as shown by the lavas scattered over the diatomite claims in the central part of the basin.

INTRUSIONS

An important structural feature of this basin is the series of large stock and dikelike masses younger than the diatomite. These masses are most prominent in the eastern part of the district, where they are intimately associated with silicified zones in the diatomite. 
The dikes of olivine basalt vary greatly in size. Those exposed in secs. $2,3,10$, and 11, T. 20 S., R. 36 E., are apparently feeders of the flows exposed on the hills to the north. The eastern dike or series of dikes is nearly a quarter of a mile wide, but small dikes only a few feet wide and related to this same series occur in profusion in this particular area. Dikes that may have been feeders of the lavas exposed in the hills along the eastern border of the district are well exposed along the road to Beulah.

Rhyolite stocks occur in this region but are much less common than the basalt dikes. The small butte in sec. 36 , T. 19 S., R. 36 E., is an interesting example of an intrusion that never reached the surface. The butte is composed of a glassy rock with columnar joints. The jointing is everywhere perpendicular to the surface, indicating cooling on the top as well as on the sides. The stocks exposed in sec. 26, T. 19 S., R. 35 E., and sec. 19, T. 19 S., R. 37 E., are also of rhyolitic composition.

\section{DIATOMITE}

\section{OCCURRENCE}

The distribution of the diatomite in the Otis Basin is shown in plate 11. In the eastern basin stream cutting has laid bare the lower silicified portion of the formation, and the high-grade diatomite is restricted to the hills (pl. 12, $A$ ). In the western basin the level of the formation is lower, and greater quantities of diatomite are available. No systematic sampling of the district was done, but a number of samples of diatomite were collected from which an idea of its value may be obtained. The color and apparent density, expressed as weight per cubic foot, of these samples are given in the table on pages 107-111. The localities from which these samples were collected are as follows:

\section{Diatomite localities in Otis Basin}

\begin{tabular}{|c|c|c|}
\hline No. & Location & Thickness \\
\hline 154 & $\begin{array}{l}\text { SE1/4 sec. } 19, \text { T. } 19 \text { S., R. } 36 \text { E.; bank on east } \\
\text { side of road. }\end{array}$ & Thickness not shown. \\
\hline 153 & $\begin{array}{l}\text { Northeast corner SE1/4sec. } 20, \text { T. } 19 \text { S., R. } 36 \text { E.; } \\
\text { road cut on Drewsey-Blue Mountain Hot } \\
\text { Springs Road. }\end{array}$ & 3 feet of massively bedded diatomite exposed. \\
\hline Dr. 1 & $\begin{array}{l}\text { Southeast corner SE1/4SW1/4 sec. } 27 \text {, T. } 19 \mathrm{~S} . \text {, } \\
\text { R. } 36 \text { E.; prospect pit. }\end{array}$ & 5 feet of massive diatomite resting on tuff. \\
\hline Dr. 11 & $\begin{array}{l}\text { Center of NW1/4 SE1/4 sec. } 28 \text {, T. } 19 \text { S., R. } 36 \text { E., } \\
\text { prospect pit. }\end{array}$ & $\begin{array}{l}5 \text { feet of massive diatomite on } 2 \text { feet of massive } \\
\text { diatomite separated by ash parting. }\end{array}$ \\
\hline $\begin{array}{l}\text { Dr. } 16 \\
\text { Dr. } 17\end{array}$ & $\begin{array}{l}\text { SW1 } 1 / 4 \mathrm{SE} 1 / 4 \text { sec. } 29 \text {, T. } 19 \text { S., R. } 36 \text { E.; bluff. } \\
\text { NE1/4 SE1/4 sec. 30, T. } 19 \text { S., R. } 36 \text { E.; pit dug } \\
\text { by side of road. }\end{array}$ & 15 feet of massive diatomite. \\
\hline Dr. 8 & $\begin{array}{l}\text { Northeast corner } \mathrm{SE}_{1 / \mathrm{SE}} 1 / 4 \mathrm{sec} \text { s3, T. } 19 \mathrm{~S} . ; \\
\text { R. } 36 \text { F.; prospect pit. }\end{array}$ & 6 feet of massive diatomite. \\
\hline Dr. 7 & $\begin{array}{l}\text { Northeast corner NE1/4 SE1/4 sec. } 33 \text {, T. } 19 \mathrm{~s} \text {., } \\
\text { R. } 36 \mathrm{E} \text {. }\end{array}$ & Not shown. \\
\hline Dr. 14 & $\begin{array}{l}\text { Southwest corner NW1/4NE1/4 sec. } 33 \text {, T. } 19 \text { S., } \\
\text { R. } 36 \text { E.; } 10 \text { feet below top of bluff. }\end{array}$ & From top of 50 -foot bed of massive diatomite. \\
\hline $\begin{array}{r}\text { Dr. } 15 \\
90\end{array}$ & $\begin{array}{l}\text { Same as Dr. } 14 \text {; at base of diatomite } \\
\text { NW } 1 / 4 \text { NW } 1 / 4 \text { sec. } 34 \text {, T. } 19 \text { S., R. } 36 \text { E.; south } \\
\text { slope of prominent white hill. }\end{array}$ & $\begin{array}{l}\text { From bottom of } 50 \text {-foot bed. } \\
10 \text { feet of massive diatomite. }\end{array}$ \\
\hline
\end{tabular}




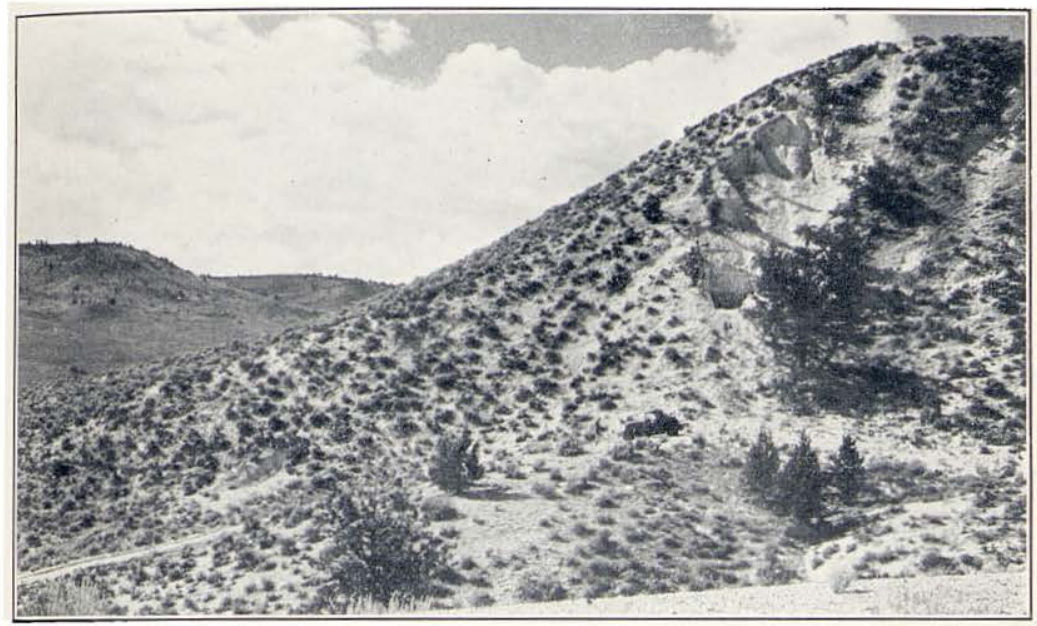

A. HILL OF DIATOMITE IN THE SE $\frac{14}{4}$ SE $1 / 4$ SEC. 14, T. 20 S., R. 36 E., OTIS BASIN, HARNEY COUNTY.

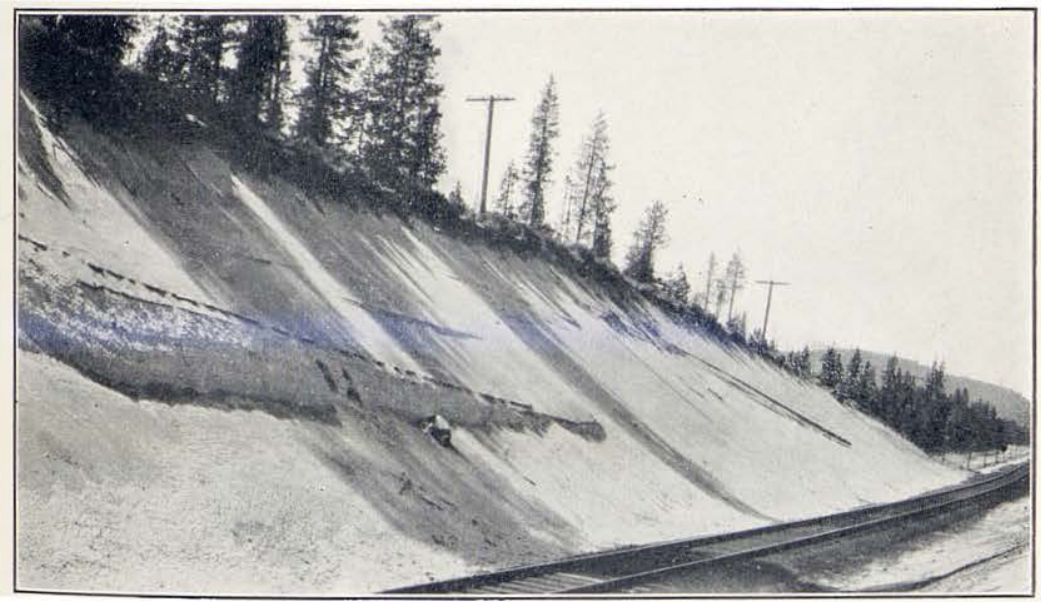

B. GRANULAR PUMICE IN CUT ON SOUTHERN PACIFIC RAILROAD ABOUT 2 MIIES NORTH OF CHEMULT. 
Diatomite localities in Otis Basin-Continued

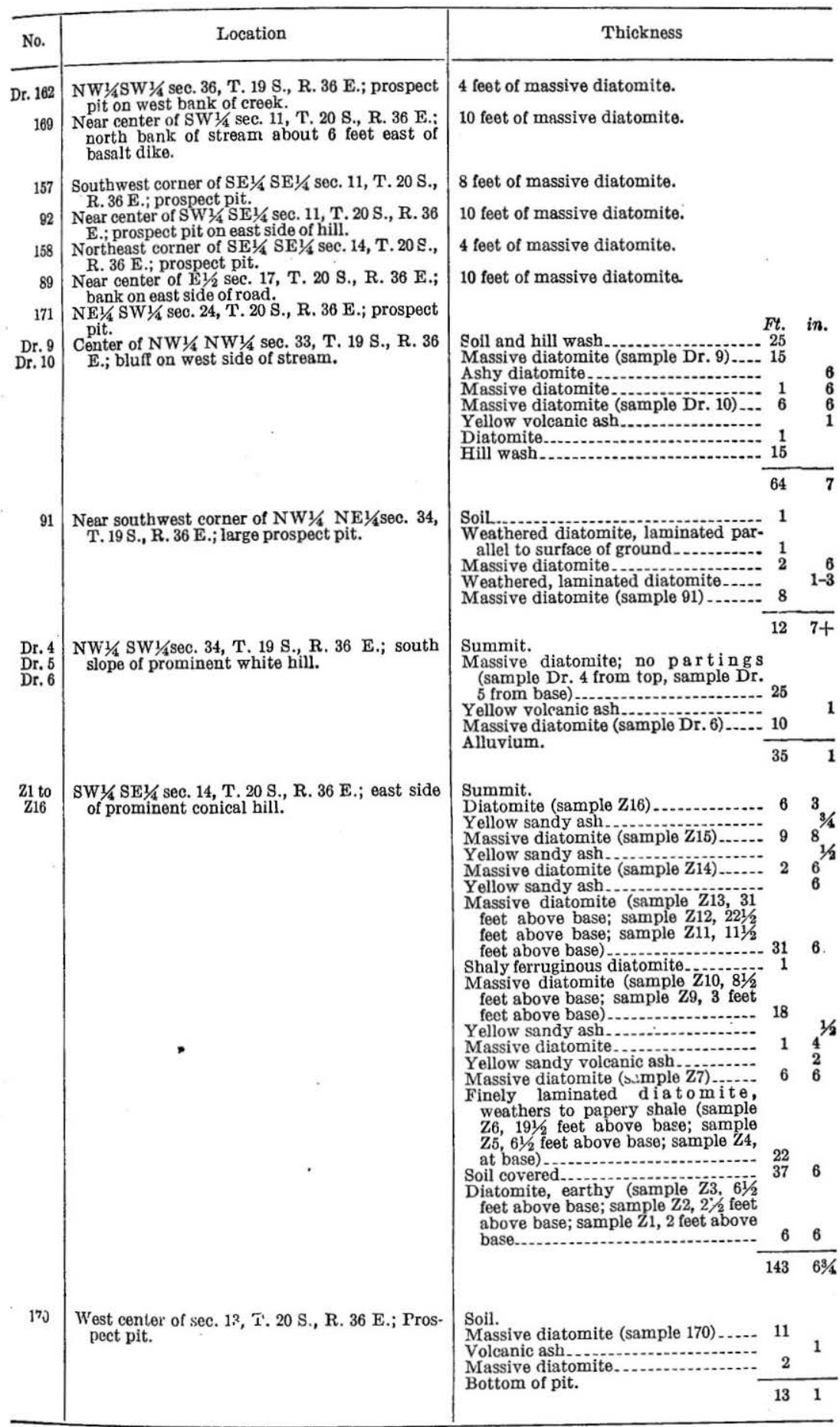




\section{QUALITY}

From the few samples collected in this district it would seem that the higher-grade diatomite is restricted to the central parts of the basin. As the edge of the deposit is approached the diatomite becomes darker, grittier, and heavier. The better grades are of high purity and white.

Toughness.-The Otis Basin diatomite is in general massive and possesses no laminated structure, but its texture, though solid, is not quite so fine as that of the Harper diatomite. Most of the Otis Basin diatomite is tough enough to be used for making sawed bricks and other forms. Its texture is rather open, and fractured surfaces have an earthy appearance. Material close to the surface is likely to be laminated because of exfoliation during weathering.

Chemical composition.-Chemical analyses of three of the samples of diatomite from this district gave the following results:

\section{Analyses of Otis Basin diatomite}

[E. Theodore Erickson, analyst]

\begin{tabular}{|c|c|c|c|c|c|c|c|}
\hline & 91 & Z4 & $\mathrm{Z} 10$ & & 91 & $\mathrm{Z} 4$ & $\mathrm{Z} 10$ \\
\hline \multirow{2}{*}{$\begin{array}{l}\mathrm{SiO}_{2} \\
\mathrm{TiO}_{2} \\
\mathrm{Fe}_{2} \mathrm{O}_{3} \\
\mathrm{Al}_{2} \mathrm{O}_{3} \\
\mathrm{CaO} \\
\mathrm{MgO} \\
\mathrm{Na}_{2} \mathrm{O}\end{array}$} & \multirow{2}{*}{$\begin{array}{r}84.48 \\
.26 \\
1.46 \\
3.66 \\
.80 \\
.18 \\
.22\end{array}$} & \multirow{2}{*}{$\begin{array}{r}81.68 \\
.31 \\
1.20 \\
5.93 \\
.54 \\
.30 \\
.24\end{array}$} & \multirow{2}{*}{$\begin{array}{r}82.78 \\
.26 \\
1.77 \\
4.61 \\
.44 \\
.22 \\
.62\end{array}$} & \multirow[t]{2}{*}{$\begin{array}{l}\mathrm{K}_{2} \mathrm{O} \\
\mathrm{SO}_{3} \\
\mathrm{Cl}_{3} \\
\mathrm{CO}_{3}\end{array}$} & $\begin{array}{l}0.16 \\
.06 \\
.06 \\
.05\end{array}$ & $\begin{array}{r}0.10 \\
.05 \\
\text { None } \\
.09\end{array}$ & $\begin{array}{r}0.24 \\
.15 \\
\text { None } \\
.08\end{array}$ \\
\hline & & & & & 91.30 & 90.44 & 91.05 \\
\hline
\end{tabular}

Microscopic examination.-Parts of the three samples submitted for chemical analysis were examined by Kenneth E. Lohman, who reports as follows concerning them:

Sample 1018, Otis Basin, Harney County, Oreg., sec. 34, T. 19 S., R. 36 E.; B. N. Moore, no. 91 (pl. 10, D).

Practically all the visible fines in this sample consist of minute fragments of diatoms. The range of sizes is small, fully 50 percent of the material being composed of valves of Melosira italica Kützing with a maximum diameter of 0.012 millimeter; and 30 percent of Melosira granulata (narrow variety) with an average diameter of 0.003 millimeter and length of 0.015 millimeter. The final 20 percent includes a few rare forms attaining a length of 0.08 millimeter and many fragments averaging 0.001 millimeter in diameter. Although the prevailing types of diatoms are mechanically strong in shape, many are broken, the fragments constituting about 40 percent of the material. The individual diatoms are fairly clean.

The principal species of diatoms are these:

Melosira italica Kützing. Dominant.

Melosira granulata (Ehrenberg) Ralfs, narrow variety. Abrundant.

Melosira arenaria Moore. Few.

Cymbella cistula (Hemprich) Kirchner. Few.

Gomphonema intricatum Kützing. Few.

Navicula radiosa Kützing. Few.

Total number of species, 13. 
Sample 1019, Otis Basin, Harney County, Oreg., sec. 14, T. 20 S., R. 36 E.; B. N. Moore, no. Z4 (pl. 10, E).

Practically all the visible fines in this sample consist of minute fragments of diatoms, although very small amounts of clay and organic matter are also present. Two species of diatoms are dominant in this material, occurring in about equal amounts; Coscinodiscus subtilis, having an average diameter of 0.06 millimeter, and Melosira granulata, having an average diameter of 0.01 millimeter. Nearly all the larger forms are broken; the smaller forms are usually whole. The individual diatoms are fairly clean.

The principal species of diatoms are as follows:

Coscinodiscus subtilis Ehrenberg. Abundant.

Melosira granulata (Ehrenberg) Ralfs. Abundant.

Melosira sp. Common.

Achnanthese lanceolata Brebisson. Few.

Melosira arenaria Moore. Few.

Sample 1020, Otis Basin, Harney County, Oreg., sec. 14, T. 20 S., R. 36 E.; B. N. Moore, no. Z10 (pl. 10, F).

This sample contains a considerable amount of volcanic ash and a small amount of clay. As in sample 1019, two species of diatoms predominate, occurring in about equal amounts. Coscinodiscus subtilis, having an average diameter of 0.05 millimeter, and Melosira granulata, having an average diameter of 0.007 millimeter. About 80 percent of the former and about 20 percent of the latter are broken. The diatoms are fairly clean.

The following are the principal species of diatoms:

Coscinodiscus subtilis Ehrenberg. Abundant.

Melosira granulata (Ehrenberg) Ralfs. Abundant.

Melosira sp. Rare.

Tetracyclus javanicus Hustedt. Rare.

\section{POSSIBLE UTILIZATION}

The various uses for which the Otis Basin diatomite may be fitted concern the technologist rather than the geologist. It may be pointed out, however, that the diatomite of this district includes varieties of a fairly high degree of purity, which might well be used for concrete admixture, insulation, and filtration. The presence of large amounts of high-grade diatomite in extremely thick beds with a minimum of overburden is favorable to the production of sawed bricks.

\section{SIZE OF DEPOSIT}

An estimate of the amount of material present must be based on a definition of what constitutes desirable diatomite. The amount of diatomite in this basin is extremely large and includes a very large proportion of high-grade material. Sufficient high-grade diatomite occurs in the central part of the basin to enable a quarry to operate for many years, but until more detailed work is done it is perhaps best not to form a definite estimate. 


\section{DEVELOPMENT}

The value of the diatomite of this district was first recognized by Albert Altnow, who, together with other local people, took up claims covering much of the more valuable part of the deposit. This land now belongs to the Diatomite Products Co., which is largely owned by H. A. Miller, of Bend, Oreg. The property is divided into two groups as follows:

North group, in T. 19 S., R. 36 E. :

White Pelican, E1/2NE1/4 sec. 33 and $W 1 / 2 N^{1} / 4$ sec. 34 .

White Goose, $\mathrm{W}^{1} 1 / 2 \mathrm{NE}^{1 / 4}$ and $\mathrm{E} 1 / 2 \mathrm{NW}^{1 / 2}$ sec. 34 .

White Swan, $\mathrm{E}^{1} 1 / 2 \mathrm{SE} 1 / 4$ sec. 33 and $\mathrm{W}^{1} 1 / 2 \mathrm{SW}^{1} / 4$ sec. 34 .

Deeded lands, W1/2 E1/2, SE $1 / 4 \mathrm{NW}^{1 / 4}, \mathrm{E}^{1} / 2 \mathrm{SW}^{1 / 4}$, and $\mathrm{SW} 1 / 4 \mathrm{SW} 1 / 4$ sec. 33 .

South group, in T. 20 S., R. 36 E. :

White Crow, E1/2 SW1/4 and W1/2 SE $1 / 4$ sec. 11.

White Dove, E1/2NW1/4 and W1/2NE1/4 sec. 14.

White Cock, E1/2 SW1/4 and W1/2 SE1/2 sec. 14.

Unpatented claims in T. 20 S., R. 36 E. :

Betty, NE $1 / 4$ sec. 28.

Dickey, SE1/4 sec. 28.

Ohio, NW $1 / 4$ sec. 27.

Heyburn, SW1/4 sec. 27.

These claims have been prospected by numerous open pits and by drill holes, but at the time of visit no production had been started. The north group of properties is in low hills which are covered with a thin soil mantle and in places with basaltic debris from the lava-covered ridge to the east. The basaltic material is probably a remnant of once more extensive landslips and, owing to its broken character, can be removed without difficulty. The diatomite that underlies the surface in this group is of good quality, and, because of the thickness of its beds, its apparent uniform distribution, and the thinness of the soil mantle, it should be good material in which to open quarries, especially for the production of sawed shapes. A minimum estimate of tonnage, based on a thickness of 9 feet over the entire 800 acres of this group and a weight of 30 pounds per cubic foot for dry material, is about 4,000,000 long tons.

The material in the south group is, perhaps, a little less pure than that in the north group. An estimate of the tonnage here is complicated by the presence of extensively silicified areas along the stream channels and valleys. This silicification, which changes the diatomite first to porcelaneous material and then to a white or brown opaline chert, is closely connected with igneous activity. The contact zones around the basalt dikes show considerable silicification of the diatomite. It is reasonable to suppose that in this region, where warm alkaline springs are so common, the underground cir- 
culation of warm alkaline waters from these igneous bodies has effected the silicification so often noticed. As a result of this silicification much of the diatomite in the eastern part of the Otis Basin is ruined for use. However, a large quantity is still unsilicified, and it is probable that much of this will be used should development of the property be commenced.

\section{QUALITY OF EASTERN OREGON DIATOMITE}

Judged from the chemical and microscopic analyses, much of the eastern Oregon diatomite is of excellent quality. Diatomite from the Terrebonne deposit has been employed for such diverse uses as cosmetics, filtration aids, and concrete admixtures. Diatomite from Harper has been used for filtration, insulation, and admixture. To state, however, just what uses a certain deposit is fitted for is impossible without intensive research. There is little literature available upon the technology of diatomite other than Calvert's work. ${ }^{43}$ The major production has come from marine deposits and from a single company in California, whose preeminent position is based on extensive private researches and resulting knowledge of the nature and behavior of its raw material. Below is given a brief description of the properties of the eastern Oregon diatomite, based on the samples collected by the Geological Survey in the seasons of 1930 and 1931.

\section{COLOR}

The eastern Oregon diatomite is in general of good color. The districts having the largest proportion of the desirable pure white material are Terrebonne and Harper. Material of excellent color also comes from the Otis Basin, Austin, Burns, Clover Creek, and Indian Creek. Most of the diatomite of the Klamath district is offcolor. Though in general the color is indicative of the degree of purity, there are many exceptions. The Indian Creek material is white in both the wet and dry states and yet is relatively impure, whereas samples from the Otis Basin that are of a light-buff color are surprisingly pure. Both color and apparent density (see p. 113) of samples collected are given in the following table:

s Calvert, Robert, Diatomaceous earth, 1930. 


\begin{tabular}{|c|c|c|}
\hline Sample & Page & Locality \\
\hline $\mathrm{Y} 1$ & 30 & $\begin{array}{l}\text { Terrebonne district, section across main quarry, near } \\
\text { center of sec. } 16, T \text {, } 14 \mathrm{~S} \text {., R. } 12 \mathrm{E} \text {. }\end{array}$ \\
\hline $\mathrm{Y} 2$ & 30 & \\
\hline $\mathrm{Y}_{3}$ & 30 & do- \\
\hline $\begin{array}{l}\mathrm{Y} 4 \\
\mathrm{Y} 5 \\
\mathrm{Y} 5\end{array}$ & $\begin{array}{l}30 \\
30\end{array}$ & 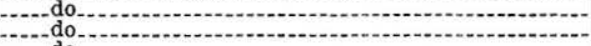 \\
\hline $\begin{array}{l}\mathrm{Y} 6 \\
\text { Y7 }\end{array}$ & $\begin{array}{l}30 \\
30\end{array}$ & 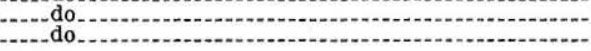 \\
\hline 174 & 34 & Burns, sec. 32, T. 23 S., R. 29 E.- \\
\hline 185 & 41 & $\begin{array}{l}\text { Klamath district: } 2 \\
\text { Northwest corner of NW1/4 sec. } 13 \text {, T. } 39 \text { S., R. } 8 \text { E. }\end{array}$ \\
\hline $\begin{array}{l}186 \\
187\end{array}$ & $\begin{array}{l}71 \\
42 \\
42\end{array}$ & Southwest corner of NW1/4 sec. 13, T. $39 \mathrm{~S}$., R. 8 E- \\
\hline 188 & 43 & $\begin{array}{l}\text { About } 75 \text { feet southwest of } 186 \\
\text { Southwest corner of NW1/4 sec. } 23, \mathrm{~T} .39 \mathrm{~S} \text {, R. } 8 \mathrm{E} \text {. }\end{array}$ \\
\hline $\begin{array}{l}191 \\
192\end{array}$ & 41 & $\begin{array}{l}\text { Southeast corner of SW1/4 sec. 5, T. } 39 \text { S., R. 8 E. } \\
\text { Southeast corner of NW' } 4 \text { sec. } 5 \text {, T. } 39 \text { S. R. } 9 \mathrm{E}\end{array}$ \\
\hline 198 & 49 & Center of NE1/4NE1/4 sec. $22, \mathrm{~T}$, $39 \mathrm{~S}$., R. $10 \mathrm{E}$ \\
\hline & 49 & $\begin{array}{l}\text { Northwest corner of NE } 1 / 4 \mathrm{NE} 1 / 4 \text { sec. } 22 \text {, T. } 39 \\
\text { S., R. } 10 \text { E. }\end{array}$ \\
\hline 200 & 50 & $\begin{array}{l}\text { Southeast corner of SW1/4 NW1/4 sec. 14, T. } 39 \mathrm{~S} ., \mathrm{R} \text {. } \\
10 \mathrm{E} \text {. }\end{array}$ \\
\hline $\begin{array}{l}201 \\
202\end{array}$ & $\begin{array}{l}50 \\
50\end{array}$ & $\begin{array}{l}0.1 \text { mile east of } 200 \text {, in railroad cut } \\
\text { South of } 201 \text {, in road cut, } 35 \text { feet lower in section }\end{array}$ \\
\hline 203 & 50 & $\begin{array}{l}\text { Southwest corner of NW1/4 NE1/4 sec. } 14, \text { T. } 39 \mathrm{~S} \text {., } \\
\text { R. } 10 \mathrm{E} \text {. }\end{array}$ \\
\hline 204 & 50 & $\begin{array}{l}\text { Southeast corner of NE1/4SE1/4 sec. } 11, \text { T. } 39 \text { S., R. } \\
10 \mathrm{E} \text {. }\end{array}$ \\
\hline $\begin{array}{l}205 \\
206\end{array}$ & $\begin{array}{l}50 \\
50\end{array}$ & $\begin{array}{l}\text { Separated from } 204 \text { by sand beds. } \\
\text { Southeast corner of NW1/4 SE1/4 sec. } 2, \mathrm{~T} .39 \mathrm{~S} \text {., R. } \\
10 \mathrm{E} \text {. }\end{array}$ \\
\hline 208 & 49 & $\begin{array}{l}\text { Northeast corner of NW1/4 NW1/4 sec. 34, T. } 38 \text { S., } \\
\text { R. } 111 / 2 \mathrm{E} \text {. }\end{array}$ \\
\hline 209 & 49 & $\begin{array}{l}\text { Northwest corner of NE1/4 SW1/4 sec. } 14, \text { T. } 38 \text { S., } \\
\text { R. } 111 / 2 \text { E. }\end{array}$ \\
\hline 210 & 49 & $\begin{array}{l}\text { Southeast corner of NE1/4NE1/4 sec. } 14, \mathrm{~T} .38 \mathrm{~S} \text {., } \\
\text { R. } 111 / 2 \mathrm{E} \text {. }\end{array}$ \\
\hline $\begin{array}{l}213 \\
214\end{array}$ & $\begin{array}{l}45 \\
45\end{array}$ & 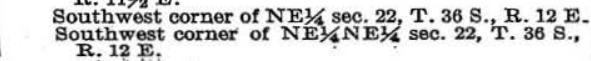 \\
\hline
\end{tabular}

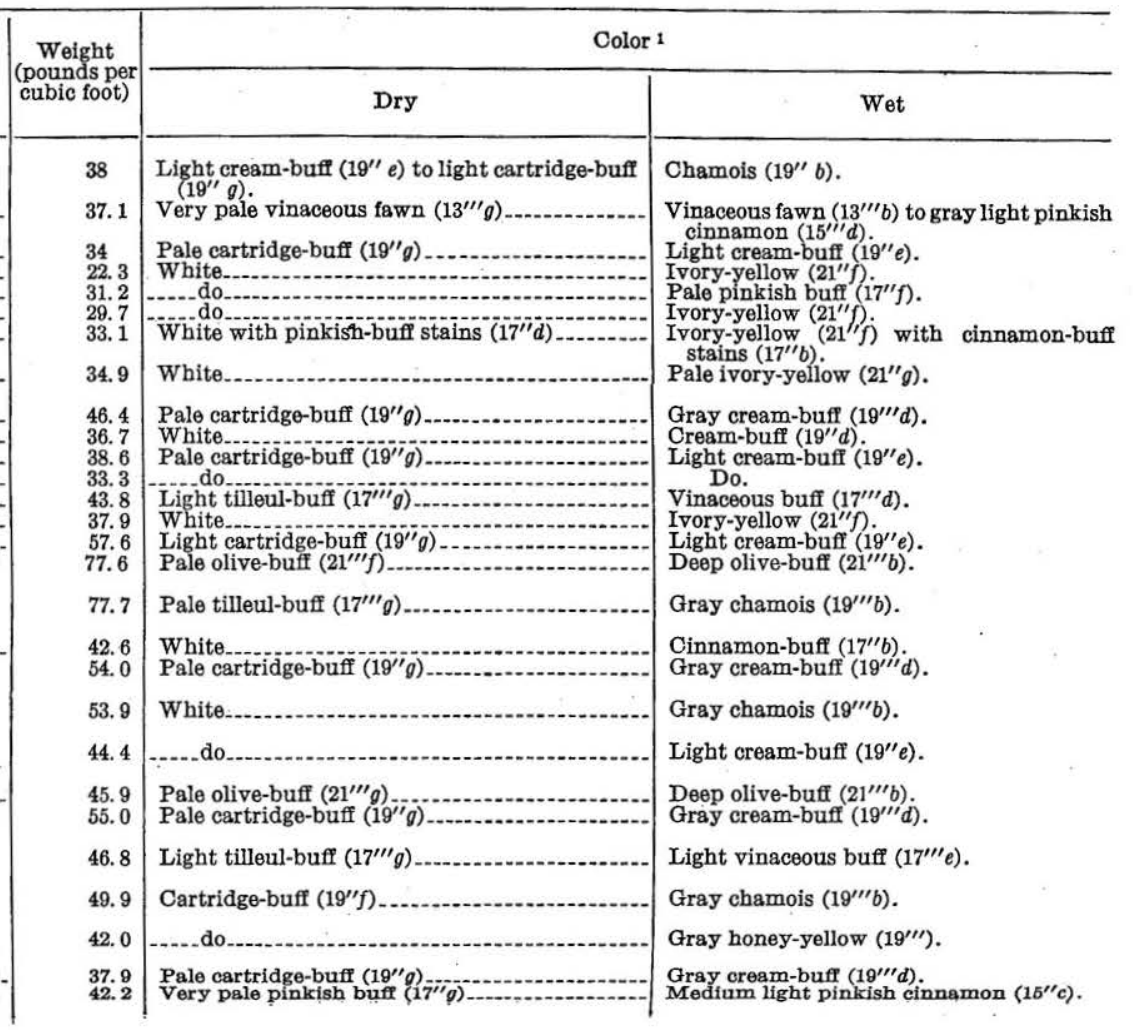




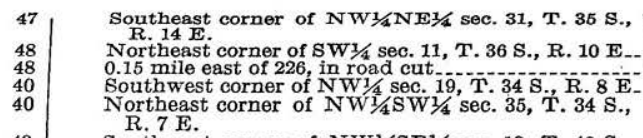
Northeast corner of $\mathrm{SW} 1 / 4 \mathrm{sec} .11, \mathrm{~T} .36 \mathrm{~S} .$, R. $10 \mathrm{E}$ Southwest corner of NW1/4 sec. 19, T. 34 S., R. $8 \mathrm{E}$ N. $7 \mathrm{E}$.

southwest corner of NW1/4SE1/4 sec. 13, T. $40 \mathrm{~S}$.,

Indian Creek, near center of sec. 1, T. 1 S., R. 39 E...

lover Creek:

ortheast corner of NW1/4 sec. 10, T. 8 S., R. 42 E

Northwest corner of NE1/4 sec. 10, T. 8 S., R. 42 E

Richland:

land:

Near center of SW1/4 sec. 19 , T.

Swayze Creek, SE1/4 sec. 34, T. 11 S., R. 43 E Austin:

Sec. 4, T. 11 S., R. $351 / 2$ E.

John Day Valley, sec. 9, T. 13 S., R. 28 E....................

Brogan, sec. 2,

W1/2 sec. 15,.T. 18 S., R. 41 E. (section 1)

on 1)

(-.......... do

79 ( 79

90

do -

$\mathrm{N} i / 2 \mathrm{sec}$.

W1/2 sec. 2, T. 19 S., R. 41 E. (section 4)
29. 0 Tilleut-buff $\left(17^{\prime \prime \prime}\right)$

39. 9 Very pale pinkish buff $\left(17^{\prime \prime} g\right)$

Tilleul-buff $\left(17^{\prime \prime \prime} f\right)$

37.2 -...do

49.3 White

59. 6 Pale cartridge-buff $\left(19^{\prime \prime} g\right)$

32.6 White

47.7 Pale cartridge-buff $\left(19^{\prime \prime}\right.$

40.5 Light pinkish buff $\left(17^{\prime \prime} f\right)$

44. 0 Tilleul-buff $\left(17^{\prime \prime \prime} f\right),-$

(17

$\begin{array}{ll}\text { 55. } 2 & \text { Pale olive-buff }\left(21^{\prime \prime \prime} f\right) \\ 49.8 & \text { Very pale olive-buff }\left(21^{\prime}\right.\end{array}$

70.2 Pale olive-buff $\left(21^{\prime \prime \prime} \prime\right)$.

29. 6 Very pale pinkish buff $\left(17^{\prime \prime} g\right)$

52.2 Very pale ochraceous buff $\left(15^{\prime} g\right)$

45. 2 -.... do

36. 9 do

34.5 -....do

36. 9 -....do-

4 do

40.1 Pale cartridge-buff $\left(19^{\prime \prime} g\right)$

42. 6 White

36.5 -...do

52.1 Cartridge-buff $\left(19^{\prime \prime} f\right)$

34. 3 White.

38. $\begin{aligned} & \text { Light cartridge-buff }\left(19^{\prime \prime} g\right) \\ & \text { White }\end{aligned}$
A vellaneous (17'"b).

Pinkish buff (17"d).

Drab (i7'"')

Pinkish bufi $\left(17^{\prime \prime} d\right)$

Light vinaceous buff $\left(17^{\prime \prime \prime} c\right)$.

Light cream-buff $\left(19^{\prime \prime} e\right)$.

Do.

Ivory-vellow $\left(21^{\prime \prime} f\right)$.

Cartridge-buff $\left(19^{\prime \prime} f\right)$.

Tawny olive $\left(17^{\prime \prime} i\right)$.

Orangeaceous olive-buff $\left(20^{\prime \prime}\right)$.

Dark olive-buff $\left(21^{\prime \prime \prime}\right)$.

Buffy brown $\left(17^{\prime \prime \prime} i\right)$.

Ochraceous buff $\left(15^{\prime} b\right)$

Pale olive-buff $\left(21^{\prime \prime \prime} f\right)$

Gray cream-buff $\left(19^{\prime \prime \prime} d\right)$

Cartridge-buff $\left(19^{\prime \prime} f\right)$

Light cream-buff $\left(19^{\prime \prime} e\right)$.

Do.

Pale cream-buff $\left(19^{\prime \prime} e\right)$

Cartridge-buff $\left(19^{\prime \prime} f\right)$.

Chamois (19")

Cartridge-buff $\left(19^{\prime \prime} f\right)$.

Cartridge-buff $\left(19^{\prime \prime} f\right)$.

${ }^{1}$ In this table the color is given according to the nomenclature of Robert Ridgway (Color standards and nomenclature, 1912). This system, though complicated, affords the only way of expressing the delicate tints of some of the dry diatomites. Ridgway's system depends upon the use of 6 fundamental colors-red, orange, yellow, green, blue, and violetwhich are gray to the pure color, and 5 other series are thus made. The first series contains 32 percent of neutral gray and is denoted by adding 1 prime (') to the number of the pure color by adding certain amounts of white to form tints, denoted by the letters $a$ to $g$, and darkened by the addition of black to form shades, denoted by the letters $h$ to $n$.

As it was not practicable for Ridgway to represent all the colors with their tints and shades in his book, there are many blanks, and it is frequently necessary for the user to interpolate. Representation of intermediate colors by symbols involves no difficulty, but Ridgway gives names only for the colors shown in the charts. However, in this table severa intermediate colors are indicated by the name of the color in the next higher series, usually prefixed by gray. These colors are (1) a buff color corresponding to $15^{\prime \prime \prime} d$, a blank in the color charts, which is named gray light pinkish cinnamon after light pinkish cinnamon (15" $d)$; (2) a buff color corresponding to $19^{\prime \prime \prime} d$, unnamed in the charts but here called gray cream-buff from cream-buff $\left(19^{\prime \prime}\right)$; (3) a buff color grayer than chamois (19"d) and therefore called gray chamois (19"o); (4) a color grayer than honey-yellow (19") and therefore called gray honey-yellow $\left(19^{\prime \prime \prime}\right)$; (5) a color called orangeaceous olive-buff that would correspond to $20^{\prime \prime \prime}$ and therefore would contain more orange than $21^{\prime \prime \prime}$, which is 25 percent orange

and 75 percent yellow and is called olive-buff.
2 Numbers in first column correspond to those of plate 6. 
Apparent density and color of eastern Oregon diatomites-Continued

\begin{tabular}{|c|c|c|c|c|c|}
\hline \multirow{2}{*}{ Sample } & \multirow{2}{*}{ Page } & \multirow{2}{*}{ Locality } & \multirow{2}{*}{$\begin{array}{c}\text { Weight } \\
\text { (pounds per } \\
\text { cubic foot) }\end{array}$} & \multicolumn{2}{|c|}{ Color } \\
\hline & & & & Dry & Wet \\
\hline $\begin{array}{r}\text { W3 } \\
\text { W4 } \\
\text { X2 } \\
\text { X3 } \\
\text { X4 } \\
\text { X5 } \\
\text { X6 } \\
\text { X7 } \\
\text { X8 } \\
\text { S1 } \\
\text { S3 } \\
\text { S4 } \\
\text { S5 } \\
\text { S6 } \\
\text { S7 } \\
\text { S8 } \\
\text { S9 } \\
\text { S10 } \\
\text { S11 } \\
\text { S12 } \\
\text { P1 } \\
\text { P2 } \\
\text { P3 } \\
\text { P4 } \\
\text { P5 } \\
\text { P6 } \\
\text { Q1 } \\
\text { Q2 } \\
\text { Q3 } \\
\text { Q4 } \\
\text { Q5 } \\
\text { Q6 } \\
\text { Q7 } \\
\text { Q8 } \\
\text { U1 } \\
\text { U2 } \\
\text { U3 } \\
\text { U4 } \\
\text { U5 } \\
154 \\
153 \\
\text { Dr. } 11\end{array}$ & $\begin{array}{l}81 \\
81 \\
82 \\
82 \\
82 \\
82 \\
82 \\
82 \\
81 \\
83 \\
83 \\
83 \\
83 \\
83 \\
83 \\
83 \\
82 \\
82 \\
82 \\
82 \\
83 \\
83 \\
84 \\
84 \\
84 \\
84 \\
86 \\
86 \\
86 \\
86 \\
86 \\
85 \\
85 \\
85 \\
86 \\
86 \\
86 \\
86 \\
86 \\
102 \\
102 \\
102\end{array}$ & 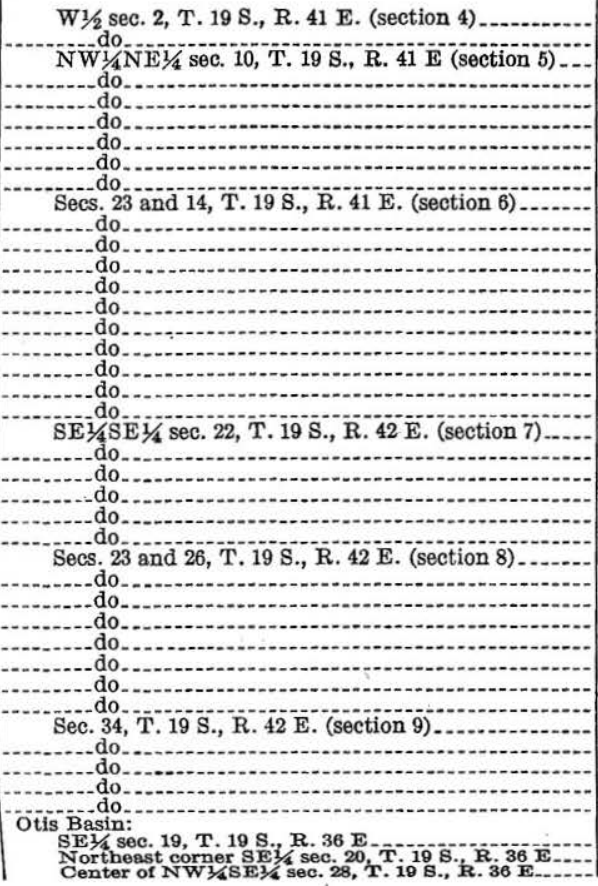 & $\begin{array}{l}36.6 \\
28.6 \\
34.9 \\
34.8 \\
37.3 \\
37.2 \\
34.6 \\
42.7 \\
38.4 \\
35.3 \\
39.3 \\
39.3 \\
41.5 \\
39.5 \\
40.2 \\
35.8 \\
61.2 \\
38.2 \\
45.7 \\
43.3 \\
33.3 \\
37.0 \\
32.3 \\
30.7 \\
37.8 \\
39.0 \\
36.8 \\
37.1 \\
36.5 \\
31.5 \\
38.0 \\
30.1 \\
28.0 \\
37.7 \\
38.2 \\
35.2 \\
40.1 \\
39.8 \\
52.9 \\
38.4 \\
37.4 \\
37.7\end{array}$ & 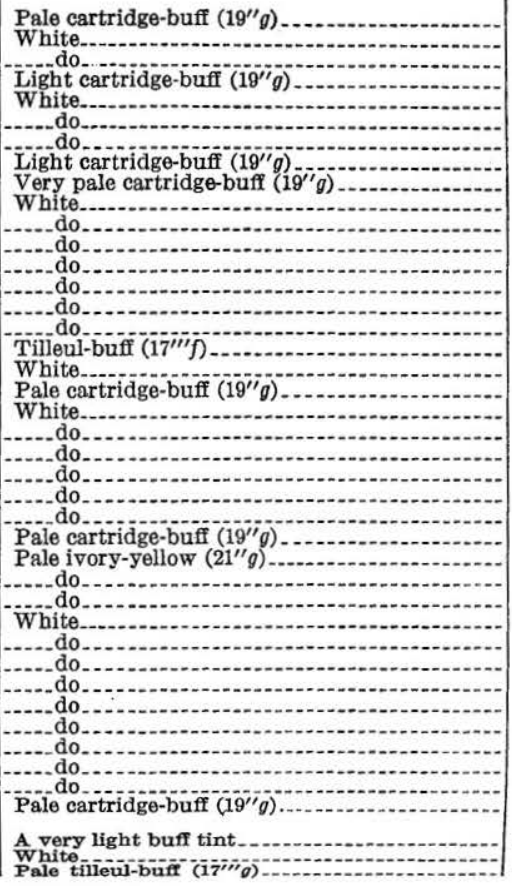 & 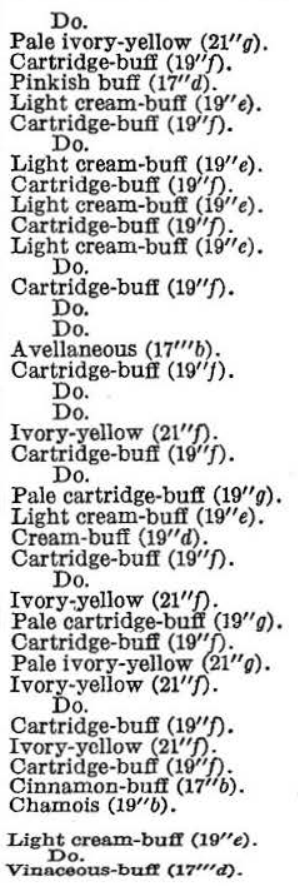 \\
\hline
\end{tabular}




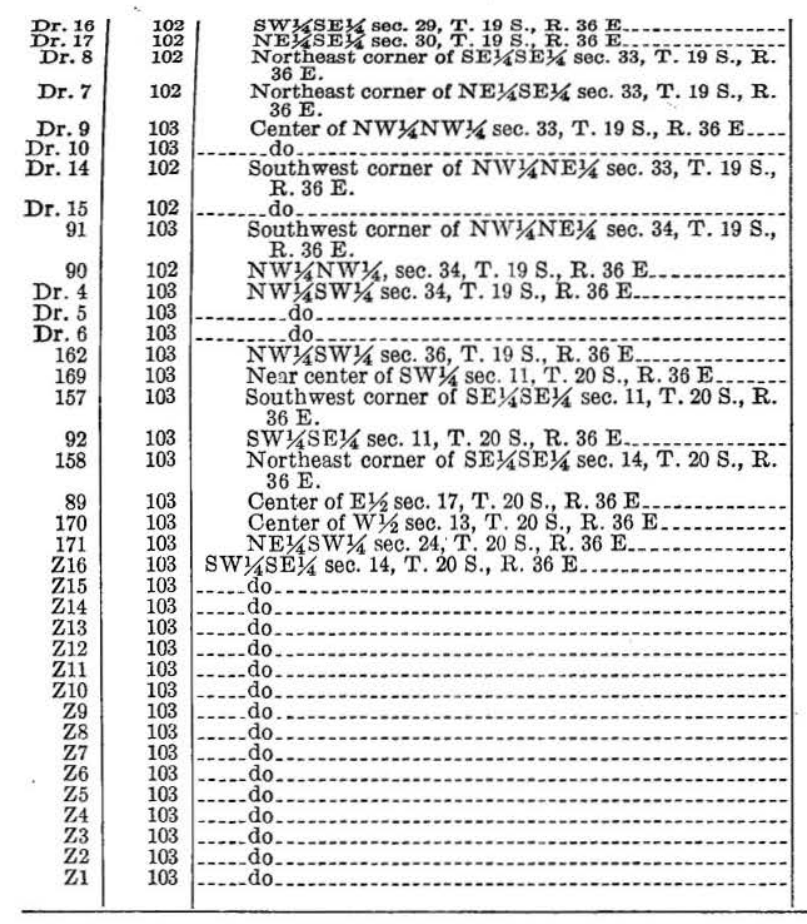

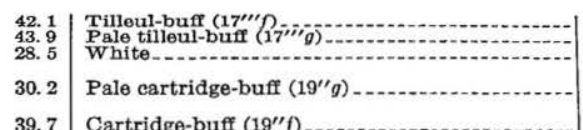
Wood-brown (17'”'). Cartridge-buft" (19"i).

Vinaceous-buff $\left(17^{\prime \prime \prime} d\right)$

39. 7 Cartridge-buff $\left(19^{\prime \prime}\right)$

43. 6 Tilleul-buff $\left(17^{\prime \prime \prime} f\right)$.

42.1 Pale tilleul-buff $\left(17^{\prime \prime \prime} g\right)$

Pale vinaceous-buff $\left(17^{\prime \prime \prime} e\right)$

Wood-brown (17'").

\begin{tabular}{l|l}
34.9 & do \\
31.9 & Pale tilleul-buff $\left(17^{\prime \prime \prime} g\right)$
\end{tabular}

31.5 do

30.0 White

27.7 Pale ivory-yeliow $(2110$

46.7 Pale tilleul-buff (17'"'g)

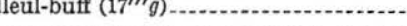

39. 5 Pale pinkish-buff $\left(17^{\prime \prime} g\right)$

32.0 White

35.2 …do

39.1 Tilleul-buff $\left(17^{\prime \prime \prime} g\right)$

36. 9 White Very pile pinkish buff $\left(17^{\prime \prime} g\right)_{-}$

43.0 -....do

47.6 do 6

45.5
40.3
Pale tilleul-buff $\left(17^{\prime \prime \prime}\right)$
Pale cartridge-buff $\left(19^{\prime \prime} g\right)$

${ }_{40.7}^{40.3}$ Pale cartridge-buff $\left(19^{\prime \prime} g\right)$......................

34.4 Very pale cartridge-bujf $\left(19^{\prime \prime} g+\right)$

37.8 Pale cartridge-buff $\left(19^{\prime \prime} g\right) \ldots$

39.7 do

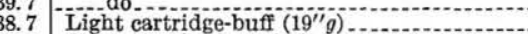

37.1 Pale cartridge-buff $\left(19^{\prime \prime} g\right)$

36.4 Very pale cartridge-buff $\left(19^{\prime \prime} g+\right)$

35.6 Pale tileul-buif

39.7 Tilleul-buff $\left(17^{\prime \prime \prime} f\right)$

Avellaneous $\left(17^{\prime \prime \prime} b\right)$

Do.

Dark tilleul-buff $\left(17^{\prime \prime \prime} e\right)$ Light cream-buff $\left(19^{\prime \prime} e\right)$ Cartridge-buff $\left(19^{\prime \prime},{ }^{\prime \prime}\right)$ Light cream-buff $\left(19^{\prime \prime} e\right)$ Wawny olive $\left(17^{\prime \prime} i\right)$

Pinkish buff $\left(17^{\prime \prime} d\right)$

Pale cartridge-buff $\left(19^{\prime \prime} g\right)$.

Pinkish buff $\left(17^{\prime \prime \prime} d\right)$.

Tawny olive $\left(1 z^{\prime \prime}\right)$.

Dark pinkish buff $\left(17^{\prime \prime} e\right)$.

Do.

Cinnamon $\left(15^{\prime \prime}\right)$.

Avellaneous $\left(17^{\prime \prime \prime} b\right)$.

Pinkish buff $\left(17^{\prime \prime} d\right)\left(1{ }^{\prime \prime} e\right)$

Dale cream-buff $\left(19^{\prime \prime} e\right)$.

Do.

Pinkish-buff $\left(17^{\prime \prime} d\right)$

Light cinnamon-buff $\left(17^{\prime \prime} c\right)$.

Dark clay-color $\left(17^{\prime \prime} h\right)$.

Tawny olive (17'i).

Avellaneous $\left(17^{\prime \prime \prime} b\right)$

Sayal-brown $\left(15^{\prime \prime} i\right)$.

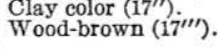


In judging the excellence of a sample of diatomite the color must be considered from a knowledge of the impurities present. Unal. tered volcanic dust or ash, which is present in all the eastern Oregon samples, is colorless, and sufficient amounts of it to render a diatomite useless would produce little color change. The alteration of this ash to clay, however, gives a greenish-yellow color, which on the oxidation of the iron present may turn dark brown. In general it might be stated that if one of these samples is white the impurities present are probably volcanic ash, small amounts of clay, and perhaps lime, but if a light greenish-yellow color is found the impurities will probably be largely clay with some volcanic ash. If the sample is brown and appears otherwise pure, a small amount of oxidized iron may be the only objectionable impurity.

\section{TEXTURE}

The texture of the eastern Oregon diatomites varies widely. The relatively unconsolidated material from Terrebonne is decidedly earthy in texture. In general the consolidated gritty diatomites have a texture resembling that of chalk, whereas the purest of the Harper diatomites resemble a very fine plaster. When examining hand specimens of these diatomites some idea of their purity may be obtained from the feel. In general the gritty feel of a sample coupled with weight above 35 pounds to the cubic foot indicates a poor quality. Most of the light-weight material, particularly that from Harper, has a smooth, almost satiny feel. There are of course exceptions, but generally these are specimens in which a coarse texture produces an illusion of impurities.

\section{FRACTURE, LAMINATION, AND TOUGHNESS}

The fracture of the greater part of the consolidated eastern Oregon diatomite is conchoidal. This is due to the almost complete lack of lamination, which is reflected in the uniform color of wet samples. Combined with this lack is a remarkable toughness, which does not seem to be related to weight per cubic foot or the presence of impurities. No tests on the strength of the eastern Oregon or other diatomite have been made by Government agencies, but private tests by reliable testing companies show that some of the Harper material is surprisingly strong. From hand examinations of the samples collected it is believed that the Harper diatomite is perhaps the toughest and that of Otis Basin is next.

The absence of lamination and the toughness of eastern Oregon diatomite are favorable for its use in the manufacture of sawed natural brick and other sawed forms. 


\section{APPARENT DENSITY}

The apparent density ${ }^{44}$ was determined for each sample of eastern Oregon diatomite, and the results are listed in the table on pages 107-111. For purposes of comparison some of the samples were dried in an electric oven for 24 hours at $105^{\circ} \mathrm{C}$. to eliminate mechanically held water. The results are as follows:

Apparent density of dried samples of diatomite

\begin{tabular}{|c|c|c|c|c|c|}
\hline No. & District & $\begin{array}{l}\text { Apparent } \\
\text { density } \\
\text { (pounds } \\
\text { per cubic } \\
\text { foot) }\end{array}$ & No. & District & $\begin{array}{l}\text { Apparent } \\
\text { density } \\
\text { (pounds } \\
\text { per cubic } \\
\text { foot) }\end{array}$ \\
\hline 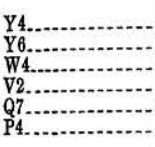 & \begin{tabular}{|l} 
Terrebonne \\
Harper \\
do do \\
do
\end{tabular} & $\begin{array}{l}21.8 \\
28.7 \\
27.1 \\
33.8 \\
26.7 \\
29.2\end{array}$ & $\begin{array}{l}7 \\
90 \\
91 \\
162 \\
186 \\
188\end{array}$ & 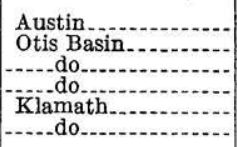 & $\begin{array}{l}29.1 \\
33.8 \\
30.1 \\
26.6 \\
34.6 \\
32.1\end{array}$ \\
\hline
\end{tabular}

The following list is given by Weigel, ${ }^{45}$ who states that the samples were dried at $105^{\circ} \mathrm{C}$. :

Apparent density of dried samples of diatomite

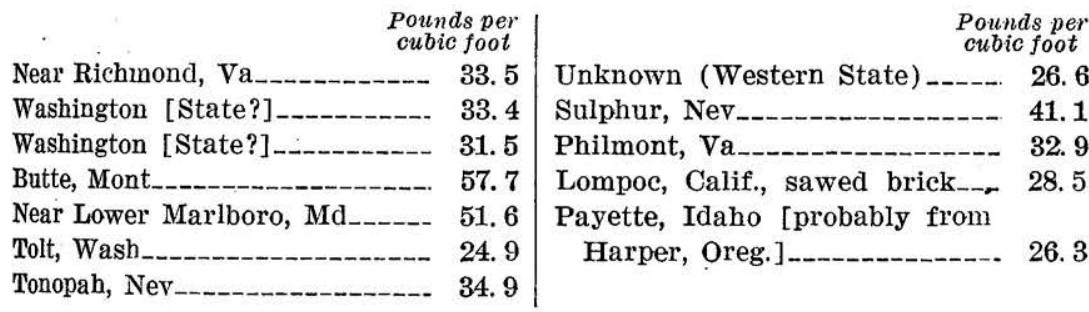

In a general way weight per cubic foot indicates the purity of a diatomite. Compaction, size of diatoms, and other things being equal, a light diatomite may be considered to be purer than a heavier one. In general, material weighing less than 30 pounds per cubic foot might be classed as excellent, below 35 as good, below 40 as fair, and above 40 as poor. That the density is not always indicative of purity is shown by a comparison of samples $\mathrm{Y} 4$ and $\mathrm{W} 4$. Sample Y4 after drying weighs 21.8 pounds per cubic foot and W4 27.1 pounds per cubic foot, though W4 is slightly lower in impurities

\footnotetext{
H By density is meant the mass per unit volume of a substance, generally expressed in metric units as grams per cubic centimeter. In most substances pore space is small and there is little difference between density and apparent density, or the weight of what appears to be a unit volume. In diatomite, however, there is so great a difference as to be readily perceptible. By crushing diatomite to break up the pores and determining the volume by displacement of a liquid the density is found to be about 2.3 , or about 140 pounds to the cubic foot, about 2.3 times as heavy as water. If the volume is determined by measurement, the apparent density is found, which may be as low as 0.3 , or about 20 pounds to the cubic foot. Because of the great porosity of pure diatomite, the apparent density is of much more interest than the true density.

${ }^{45}$ Weigel, W. M., Technology and uses of silica and sand: U. S. Bur. Mines Bull. 266. p. 192,1927 .
} 


\section{NONMETALLIC MINERAL RESOURCES OF EASTERN OREGON}

than Y4. The difference is due to differences in compaction. Sam. ple 222, from Sprague River, Klamath County, weighs only 29 pounds per cubic foot but is not as pure chemically as the heavier samples from Harper and the Otis Basin.

\section{CHEMICAL COMPOSITION}

Chemical analyses of some of the diatomite samples have been made in the chemical laboratory of the Geological Survey. These analyses are of the same order of accuracy as those of igneous rocks. The silica was determined by the method outlined by Hillebrand, and his procedure was used in determining other constituents. No attempt was made to determine combined water or organic matter, as on ignition small amounts of volatile salts escape which may increase the percentage of "loss on ignition" by as much as 2 percent of the total analysis.

The analyses as a whole show a high silica content. On recomputing the analyses to a basis free from organic matter and water, the following results were obtained:

Analyses of eastern Oregon diatomite recomputed to water-free basis

\begin{tabular}{|c|c|c|c|c|c|c|c|c|}
\hline & $\begin{array}{l}\text { Clover } \\
\text { Creek }\end{array}$ & \multicolumn{4}{|c|}{ Klamath district } & \multicolumn{3}{|c|}{ Otis Basin } \\
\hline & 5 & 187 & 222 & 227 & 232 & 91 & $\mathrm{Z} 4$ & $\mathrm{Z} 10$ \\
\hline \multirow[t]{2}{*}{$\begin{array}{l}\mathrm{SiO}_{2} \\
\mathrm{TiO}_{2} \\
\mathrm{Fe}_{2} \mathrm{O}_{8} \\
\mathrm{Al}_{2} \mathrm{O}_{32} \\
\mathrm{CaO} \\
\mathrm{MgO} \mathrm{O} \\
\mathrm{Na} \mathrm{O}_{2} \\
\mathrm{~K}_{2} \mathrm{O}_{2} \\
\mathrm{SO}_{3} \\
\mathrm{Cl}_{3} \\
\quad \text { Total }\end{array}$} & $\begin{array}{r}81.27 \\
.50 \\
5.02 \\
11.13 \\
.66 \\
.61 \\
.36 \\
.18 \\
.03 \\
.04 \\
.10\end{array}$ & $\begin{array}{r}83.39 \\
.71 \\
2.94 \\
9.54 \\
1.33 \\
.41 \\
1.19 \\
.29 \\
.07 \\
\text { None } \\
.12\end{array}$ & $\begin{array}{r}88.76 \\
.14 \\
2.37 \\
6.96 \\
.44 \\
.27 \\
.39 \\
.17 \\
.20 \\
.07 \\
.23\end{array}$ & $\begin{array}{r}74.41 \\
.98 \\
3.78 \\
16.39 \\
1.77 \\
.97 \\
1.02 \\
.48 \\
.03 \\
.12 \\
.05\end{array}$ & $\begin{array}{r}82.68 \\
.49 \\
3.17 \\
9.24 \\
2.08 \\
.69 \\
.78 \\
.35 \\
.03 \\
.37 \\
.12\end{array}$ & $\begin{array}{r}92.45 \\
.28 \\
1.60 \\
4.00 \\
.85 \\
.20 \\
.24 \\
.18 \\
.07 \\
.07 \\
.06\end{array}$ & $\begin{array}{r}90.31 \\
.34 \\
1.32 \\
6.56 \\
.60 \\
.33 \\
.27 \\
.11 \\
.06 \\
\text { None } \\
.10\end{array}$ & $\begin{array}{r}90.89 \\
.28 \\
1.93 \\
5.05 \\
.47 \\
.23 \\
.67 \\
.28 \\
.16 \\
\text { None } \\
.06\end{array}$ \\
\hline & 100.00 & 100.00 & 100.00 & 100.00 & 100.00 & 100.00 & 100.00 & 100.00 \\
\hline & \multicolumn{7}{|c|}{ Harper } & $\begin{array}{l}\text { Terre- } \\
\text { bonne }\end{array}$ \\
\hline & S7. & T3 & U4 & V2 & W4 & $\mathrm{X} 8$ & P4 & Y4 \\
\hline $\begin{array}{l}\mathrm{SiO} \\
\mathrm{TiO}_{2} \\
\mathrm{Fe}_{2} \mathrm{O}_{3} \\
\mathrm{Al}_{2} \mathrm{O}_{3} \\
\mathrm{CaO} \\
\mathrm{MgO} \mathrm{NO}_{2} \\
\mathrm{Na}_{2} \mathrm{O}_{2} \\
\mathrm{~K}_{2} \mathrm{O}_{2} \\
\mathrm{OO}_{3} \\
\mathrm{Cl}_{3}\end{array}$ & $\begin{array}{r}88.20 \\
.30 \\
3.30 \\
4.45 \\
1.43 \\
.76 \\
1.08 \\
.18 \\
.11 \\
.02 \\
.17\end{array}$ & $\begin{array}{r}91.75 \\
.20 \\
2.18 \\
4.09 \\
.63 \\
.33 \\
.37 \\
.22 \\
.13 \\
\text { None } \\
.10\end{array}$ & $\begin{array}{r}83.39 \\
.30 \\
2.21 \\
7.46 \\
.98 \\
.72 \\
1.61 \\
.35 \\
.98 \\
1.86 \\
.14\end{array}$ & $\begin{array}{r}92.59 \\
.20 \\
2.11 \\
3.59 \\
.72 \\
.42 \\
.05 \\
.15 \\
.07 \\
\text { None } \\
.10\end{array}$ & $\begin{array}{r}94.51 \\
.15 \\
1.15 \\
2.87 \\
.53 \\
.19 \\
.31 \\
.04 \\
.10 \\
\text { None } \\
.15\end{array}$ & $\begin{array}{r}88.08 \\
.36 \\
2.12 \\
7.09 \\
1.08 \\
.46 \\
.38 \\
.22 \\
.04 \\
\text { None } \\
.15\end{array}$ & $\begin{array}{r}91.92 \\
.20 \\
1.27 \\
3.53 \\
.42 \\
.25 \\
1.24 \\
.16 \\
.76 \\
.20 \\
.05 \\
\end{array}$ & $\begin{array}{r}93.03 \\
.18 \\
1.67 \\
2.97 \\
.89 \\
.39 \\
.53 \\
.16 \\
.11 \\
.02 \\
.09 \\
\end{array}$ \\
\hline Total & 100.00 & 100.00 & 100.00 & 100.00 & 100.00 & 100.00 & 100.00 & 100.00 \\
\hline
\end{tabular}

${ }^{40}$ Hillebrand, W. F., The analysis of silicate and carbonate rocks: U. S. Geol. Survey Bull. 700, pp. 89-105, 1919. 
$\mathrm{SiO}_{2}$.- In most of these samples the silica is relatively high. Several interesting facts may be noted in connection with the silica content. Samples Z4 and Z10, from the Otis Basin, are rather dark in color (see table, p. 111) and rather dense, Z4 weighing 45.5 and Z10 38.7 pounds per cubic foot, yet they are much higher in silica than sample 5, from Clover Creek, which is white and weighs only 32.6 pounds per cubic foot. The samples from the Klamath district likewise show a low silica content, but this was expected from the harsh feel of the specimens, their color, especially when wet, and their density. Scattered through the Clover Creek material are sizable pieces of basaltic material, some of which may not have been removed and thus may have contaminated the sample. The similarity in composition of Z4 and Z10 to sample 91 of the same deposit is also surprising, considering the fact that 91 is white and weighs only 30.8 pounds per cubic foot. The two samples with the highest silica content are W4 of Harper and $\mathrm{Y} 4$ of Terrebonne. W4 weighs 27.1 pounds per cubic foot oven-dried and Y4 21.8 pounds per cubic foat. The difference in apparent density of these samples is clearly due to the greater degree of consolidation of W4, which is a very strong sample; Y4 is very poorly consolidated.

$\mathrm{TiO}_{2}$ - - Titania is present in all the samples in variable amount. It is probably associated with the clay. Its irregular relation to the total alumina present suggests that part of it is contained in the volcanic glass fragments rather than being wholly in clay.

$\mathrm{Fe}_{2} \mathrm{O}_{3}$. - Iron is present in all samples in moderate percentages. The white color of most samples, both wet and dry, would indicate that much of the iron is in the volcanic glass present rather than in a free state. In view of the basaltic nature of much of the rock surrounding the deposits, the iron percentage seems remarkably low. A surprising thing is the low percentage of iron in samples $\mathrm{Z} 4$ and $\mathrm{Z10}$, which from their color would be considered highly iron-bearing. The high iron content of sample 5 is also a surprise, because of such apparent indications of purity as whiteness and low apparent density. In the Harper samples the iron ranges from 1.15 to 3.30 with no effect on the color. The lowest iron content appears to be that of W4, from Harper.

$\mathrm{Al}_{2} \mathrm{O}_{3}$. - The alumina is by far the most abundant impurity in these samples. In general it appears to vary with the iron content, but sample S7, from Harper, shows a high iron content with rather low alumina. As with other impurities, no definite relation can be discerned in the hand specimen between the amount of alumina and the properties of the diatomite, except perhaps in its feel. The softest or smoothest samples appear to be uniformly low in alumina and iron, with the notable exception of sample 5, from Clover Creek, whereas the harsher grades are ordinarily higher in alumina.

$\mathrm{CaO}$ and $\mathrm{MgO}$.- Lime and magnesia are present in all samples in considerable amounts, probably as constituents of the small glass particles but certainly not as carbonates, sulphates, or chlorides, for, as shown, these ions are very poorly represented.

$\mathrm{Na}_{2} \mathrm{O}$. - Soda is present in all samples but in variable amounts. Samples 187, 227 , and 232 show considerable, but sample 222 , which came from a younger deposit, has much less. Sample 187 , which has 1.19 percent of soda, has no chlorine and very little sulphate. The high soda content is probably related to the relatively large amount of impurities in the form of silicates present. In sample U4 both soda and chlorine are high, indicative of salt. The salt was probably introduced after deposition, by mineral springs, which are common in the Harper region, especially as the other samples show very low chlorine or sulphate content. 


\section{NONMETALLIC MINERAL RESOURCES OF EASTERN OREGON}

$K_{2} \mathrm{O}$.-Potash is present in all samples in rather small amounts and apparently does not vary greatly with the other impurities.

$\mathrm{SO}_{3}, \mathrm{Cl}, \mathrm{CO}_{2}$. - The percentages of the sulphate, chloride, and carbonate radicles are very low in all the samples except where foreign salts have been introduced after deposition.

No tests of diatomite from eastern Oregon have been made to determine the amount of acid-soluble material present. Because many of the impurities are present as glass, soluble matter is probably lower than the analyses would seem to indicate.

The following table shows the chemical composition of diatomite from several localities in the United States.

Analyses of diatomite from the United States ${ }^{1}$

\begin{tabular}{|c|c|c|c|c|c|c|c|c|c|c|}
\hline & 1 & 2 & 3 & 11 & 15 & 18 & 19 & 20 & 21 & 22 \\
\hline $\begin{array}{l}\mathrm{SiO} \\
\mathrm{Al}_{2} \mathrm{O}_{3} \\
\mathrm{Fe}_{2} \mathrm{O}_{3} \\
\mathrm{CaO} \\
\mathrm{MgO} \\
\mathrm{Na}_{2} \mathrm{O} \\
\mathrm{K}_{2} \mathrm{O}_{2} \\
\mathrm{H}_{2} \mathrm{O} \text { above } 105^{\circ} \mathrm{C}_{2} \\
\mathrm{CO}_{2}+\text { organic matter... }\end{array}$ & $\begin{array}{l}88.40 \\
2.05 \\
1.13 \\
.34 \\
.52 \\
(2) \\
(2) \\
6.08 \\
.31\end{array}$ & $\begin{array}{l}86.24 \\
3.05 \\
1.02 \\
.18 \\
.63 \\
(2) \\
(2) \\
5.62 \\
1.20\end{array}$ & $\begin{array}{l}80.40 \\
6.88 \\
2.12 \\
.86 \\
1.17 \\
(2) \\
\text { (2) } \\
6.12 \\
.61\end{array}$ & $\begin{array}{r}77.88 \\
6.80 \\
1.90 \\
.33 \\
.13 \\
3.37 \\
2.02 \\
5.20 \\
2.56\end{array}$ & $\begin{array}{r}86.74 \\
4.64 \\
1.46 \\
.85 \\
.37 \\
0 \\
0 \\
5.80 \\
.40\end{array}$ & $\begin{array}{r}92.49 \\
.89 \\
1.46 \\
.63 \\
.46 \\
(2) \\
(2) \\
3.08 \\
1.01\end{array}$ & $\begin{array}{l}93.15 \\
1.04 \\
1.24 \\
.50 \\
.31 \\
(2) \\
(2) \\
3.09 \\
.41\end{array}$ & $\begin{array}{r}86.60 \\
2.62 \\
2.58 \\
.57 \\
.56 \\
(2) \\
(2) \\
5.08 \\
.12\end{array}$ & \begin{tabular}{r}
81.13 \\
7.42 \\
3.03 \\
1.79. \\
.31 \\
\hdashline 4.86 \\
.62
\end{tabular} & \begin{tabular}{r}
91.45 \\
2.60 \\
.83 \\
.70 \\
.36 \\
\hdashline... \\
3.41 \\
.97
\end{tabular} \\
\hline & 98.83 & 97.96 & 98.16 & 100.19 & 100.28 & 100.02 & 99.74 & 98.13 & 99.16 & 100.51 \\
\hline
\end{tabular}

1 Eardley-Wilmot, V. L., Diatomite, its occurrence, preparation, and uses: Canada Dept. Mines, Mines Branch, Pub. 691, p. 108, 1928.

2 Not determined.

1. Celite Co., No. 16 filter quarry, Lompoc, Calif.

2. Celite Co., No. 38 Super-Cel quarry, Lompoc, Calif.

3. Celite Co., main brick quarry, Lompoc, Calif.

11. Monterey Products Co., top beds, Monterey, Calif.

15. Deschutes River, best grade, Terrebonne, Oreg.

18. Deschutes River, bottom bed, large tubular diatoms, Terrebonne, Oreg.

19. J. Webley deposit, best grade crude, Burke, Wash.

20. Great Western Silica Co., average grade, Kittitas, Wash.

21. Triolite Co., average grade, Carlin, Nev.

22. Electro Silicon Co., silver polish grade, Virginia City, Nev.

These analyses have been recomputed to a water-free basis with the following results:

\begin{tabular}{|c|c|c|c|c|c|c|c|c|c|c|}
\hline & 1 & 2 & 3 & 11 & 15 & 18 & 19 & 20 & 21 & 22 \\
\hline \multirow[t]{2}{*}{$\begin{array}{l}\mathrm{SiO}_{2} \\
\mathrm{Al}_{2} \mathrm{O}_{3} \\
\mathrm{Fe}_{2} \mathrm{O}_{3} \\
\mathrm{CaO} \\
\mathrm{MgO} \mathrm{Na}_{2} \mathrm{O} \\
\mathrm{K}_{2} \mathrm{O}\end{array}$} & $\begin{array}{l}95.31 \\
2.21 \\
1.22 \\
.36 \\
\text { (1) } \\
\text { (1) } \\
\text { (1) }\end{array}$ & $\begin{array}{r}92.32 \\
3.30 \\
1.10 \\
.19 \\
\text { (1) } \\
\text { (1) }\end{array}$ & $\begin{array}{r}87.35 \\
7.48 \\
2.30 \\
.93 \\
1.27 \\
\text { (1) } \\
\text { (1) }\end{array}$ & $\begin{array}{r}80.94 \\
7.05 \\
2.00 \\
.34 \\
.14 \\
3.55 \\
2.13\end{array}$ & $\begin{array}{r}90.75 \\
4.91 \\
1.54 \\
.88 \\
.38 \\
0 \\
0\end{array}$ & $\begin{array}{l}95.40 \\
.91 \\
1.40 \\
.65 \\
.45 \\
\text { (1) } \\
\text { (1) }\end{array}$ & $\begin{array}{r}96.38 \\
1.08 \\
1.28 \\
.52 \\
.32 \\
\hdashline-2 \\
\hdashline-9\end{array}$ & $\begin{array}{r}93.07 \\
2.82 \\
2.77 \\
.61 \\
.60 \\
\hdashline \\
\hdashline\end{array}$ & $\begin{array}{r}86.03 \\
7.87 \\
3.21 \\
1.90 \\
.33 \\
\hdashline \\
\hdashline\end{array}$ & \begin{tabular}{r}
94.18 \\
2.65 \\
.86 \\
.72 \\
.36 \\
\hdashline... \\
.. .2 \\
\end{tabular} \\
\hline & 99.66 & 97.58 & 99.93 & 96.15 & 98.46 & 98.81 & 99.58 & 99.87 & 99. 34 & 98.77 \\
\hline
\end{tabular}

1 Not determiner.

These analyses, according to a letter received from Mr. EardleyWilmot, were made by using a single precipitation of silica. Though the analyses were made on samples collected from localities un- 
known to me, I believe that they are as unbiased as any available in the literature. The analyses were made by the Mines Branch, Department of Mines, Canada. Comparison of the analyses shows that as far as chemical composition is concerned, unmilled diatomite from most of the eastern Oregon localities compares favorably with that from other States. It possesses several excellent qualities besides high silica content. The low content of $\mathrm{SO}_{3}$ (sulphate) and $\mathrm{Cl}$ (chloride) indicates an absence of hygroscopic or water-absorbing salts such as magnesium chloride and calcium chloride, which may make complete drying, especially in marine earths, difficult. The absence of hygroscopic salts is a distinct advantage in insulation material, where dryness of the insulant at room temperatures is essential. The low content of $\mathrm{SO}_{3}$ (sulphate), $\mathrm{Cl}$ (chloride) and $\mathrm{CO}_{2}$ (carbonate) also indicates a low percentage of water-soluble material, an important requisite for diatomite to be used as a filler. The purer grades of eastern Oregon diatomite should be especially well suited for fillers in such articles as rubber battery boxes, where contact with acids is unavoidable. Most of the iron $\left(\mathrm{Fe}_{2} \mathrm{O}_{3}\right)$, alumina $\left(\mathrm{Al}_{2} \mathrm{O}_{3}\right)$, lime $(\mathrm{CaO})$, and magnesia $(\mathrm{MgO})$, as well as the soda $\left(\mathrm{Na}_{2} \mathrm{O}\right)$ and potash $\left(\mathrm{K}_{2} \mathrm{O}\right)$, are present as silicates in the form of particles of volcanic glass or clay, which are relatively insoluble. The relatively small amounts of soluble material and the practical absence of hygroscopic salts should make these diatomites of particular value in many ways.

\section{MICROSCOPIC EXAMINATIONS}

Many samples of the eastern Oregon diatomite have been examined under the microscope, and the results are set forth on preceding pages. In general, these examinations show that the material is relatively pure. In a few samples lime has been found, but the impurities are present chiefly as volcanic ash and to a lesser extent as clay. The individual diatoms are clean, and in general the fines are small in amount. There is considerable variation in size of the diatoms from different localities, but in general those of the Miocene are smaller than those of the Pleistocene and recent deposits.

\section{CONCLUSIONS}

The purer diatomites of eastern Oregon form a large percentage of the total. Very large tonnages are available in deposits which are accessible to railroads and in which mining costs should be low. It is believed that these deposits can produce under proper mining. conditions large amounts of uniform diatomite which would be acceptable to industrial concerns. It must be emphasized, however, 
that success in the production of diatomite depends to a great extent upon market conditions. Calvert ${ }^{47}$ says :

There are known so many deposits of diatomaceous earth today that com. petition eliminates all but the best from commercial development. A slight inferiority in quality or a slight handicap with respect to such a factor as transportation is sufficient to prevent profitable exploitation.

To these handicaps might be added that of overcapitalization of projects. By keeping capitalization of enterprises down to amounts commensurate with the value of the products, by selling on a basis of definite specifications for different products (which involves in. dustrial research), and by mining carefully to keep costs down and quality up, it is possible that with a moderate price diatomite from eastern Oregon might compete in the market with diatomite from other areas.

\section{LIMESTONE}

\section{OCCURRENCE}

Limestone occurs at several localities in eastern Oregon. Deposits of commercial importance are limited to the dense crystalline limestones of the Paleozoic and Mesozoic rocks of the Ochoco and Blue Mountains and Wallowa and Baker Counties, though occurrences of calcareous tufa and caliche in the Tertiary strata in other districts are reported from time to time.

No systematic location of the deposits can be noted, for the intense folding and faulting through which the pre-Cretaceous rocks have passed have thoroughly disrupted the continuity of most of the beds and in many places have produced irregular isolated lenticular bodies.

Many of the limestones of eastern Oregon are of very high purity and might be classed among the limestones which burn to a "rich" or "fat" high-calcium lime. Most of the limestones are suitable for cement making, and some deposits offer material suited for quarrying for building stone. The black limestone of the Black Marble \& Lime Co., of Enterprise, furnishes a handsome jet-black stone when sawed and polished. Marbles of pure-white color are available in the region of the Matterhorn, on Hurricane Creek in the Wallowa Mountains, and light-gray to white marbles might well be developed on Connor and Fox Creeks.

The limestone deposits of eastern Oregon are unfortunately not well located with respect to markets. The population of eastern Oregon is too scattered to consume any large amounts of lime products, and the centers of population on the Pacific coast can be reached only by long railroad hauls of 400 to 500 miles. The greater number of the deposits are not located favorably with respect to existing

${ }^{47}$ Calvert, Robert, Diatomaceous earth, p. 35, 1931. 
railroads, though there are a few exceptions. The value of these accessible deposits will depend largely on the type of limestone available and the prevailing freight rates to the coast. It is possible that certain of these deposits, notably that of the Black Marble \& Lime Co., at Enterprise, could yield high-grade lime that might be shipped at a profit. The utilization of most of these deposits, however, is a matter of future rather than present interest.

The deposits described in this report lie in Wallowa, Baker, Crook, Grant, and Wheeler Counties. (See pl. 1.) These deposits were visited by $R$. W. Richards and me in 1930, and in 1931 I spent 3 weeks in further detailed investigation of the Wallowa Mountain and Connor Creek deposits. In this report only deposits that contain amounts sufficient to warrant large-scale development under favorable conditions are considered. This does not imply condemnation of certain smaller deposits from which excellent lime is produced from time to time.

Valuable information was furnished by Dr. E. W. Lazell, of Portland. Assistance and information was given by many other persons. J. C. Reed and H. G. Mitchell, of the United States Geological Survey, have supplied the description of the deposit at Lime. James Gilluly, another colleague, furnished much general information concerning parts of the region where limestone is present.

\section{WALLOWA COUNTY}

Limestone of Mesozoic or Paleozoic age occurs in three districts in Wallowa County-namely, in the Snake River Canyon, the Imnaha Canyon, and the Wallowa Mountains. The numerous deposits in the Snake River Canyon were not investigated, because of their inaccessibility by boat, railroad, or road. The deposit on Imnaha River occupies a relatively small area. The largest deposits occur in the Wallowa Mountains. Some use has been made of a black limestone from one of these near Enterprise.

\section{LIMESTONE ON IMNAHA RIVER}

The deposit on the Imnaha River, which was examined in 1930, is in sec. 15 , T. 3 S., R. 48 E., at an altitude of about 2,500 feet. The canyon at this place is rugged, the walls rising steeply as a series of terraces to an altitude of nearly 6,500 feet. The limestone is part of the pre-Cretaceous rocks exposed on the canyon bottom by local erosion of the Miocene lavas that form the walls. These lavas, which form the country rock, are nearly 4,000 feet thick.

The southern outcrop of limestone forms a bluff 170 feet high on the west side of the river. The rock is thick-bedded, light gray, slightly recrystallized, and in places considerably silicified. The 
beds strike N. $75^{\circ} \mathrm{E}$. and $\operatorname{dip} 25^{\circ} \mathrm{N}$. Some of the beds are crinoidal and weather to a coarse sand of calcite-fragments. This limestone might be used in the manufacture of cement but probably not otherwise.

About 0.4 mile north of the locality just mentioned low banks of fossiliferous limestone lie along the river. This is a bluish-gray thick-bedded noncrystalline, soft rock, with the same strike and dip as the southern outcrop. Fossils from this limestone were submitted to J. B. Reeside, Jr., of the United States Geological Survey, who furnished the following list:

Lot 15550 (original number, 40). Limestone on the Imnaha River in the NE1 $1 / 4$ sec. 15 , T. 2 S., R. 48 E. :

Spiriferina aff. S. homfrayi Gabb.

Spiriferina aff. S. alia Hall and Whitfield.

Spiriferina pittensis Smith.

Spiriferina, probably n. sp.

Lima aff. L. martini Smith, probably n. sp.

Juvavites (Anatomites) knowltoni Smith.

Capulus? sp.

This is an Upper Triassic fauna.

An analysis of this limestone was made in the laboratory of the Geological Survey with the following result:

Analysis of limestone from Imnaha River, oreg.

[J. G. Fairchild, analyst]

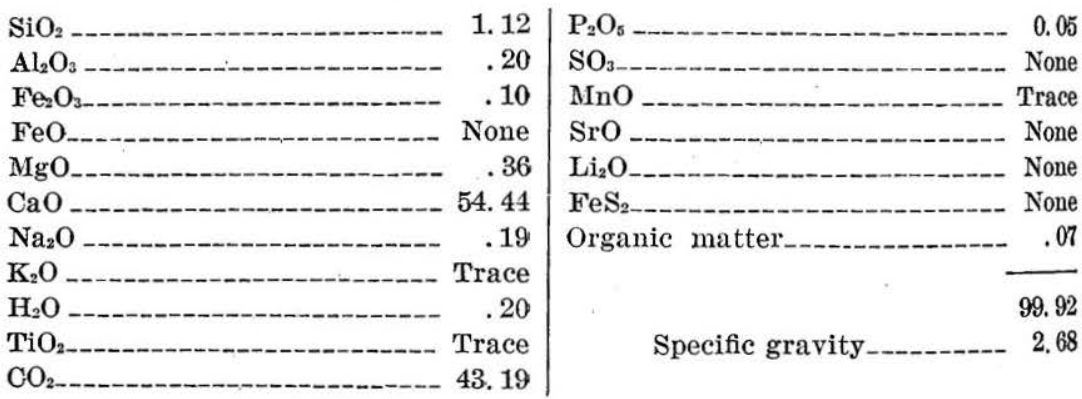

A minimum estimate of the amount of limestone in this district is 9,000,000 long tons, based on an outcrop of 320 acres and a minimum thickness of 9 feet above stream level. Considerably greater quantities are probably masked by alluvium, but the lack of adequate transportation facilities and the presence of much silicified material prevents any but a local use. 
LOCATION

The Wallowa Mountains, which have also been known under the names of Eagle Creek Range, Powder River Range, and Cornucopia Range, include the southwestern part of Wallowa County, the southeastern part of Union County, and the northeastern part of Baker County. The marble and limestone deposits here described are situated on the Lostine River and Hurricane Creek, tributaries of the Wallowa River, which drains northward into the Snake.

\section{NATURE OF INVESTIGATIONS}

Little information is available regarding the geology of the Wallowa Mountains. The mining districts of the southern part were described by Lindgren. ${ }^{48}$ Swartley, on the basis of a later reconnaissance, gives a general account of the rocks and mines of the Wallowa Mountains. ${ }^{49}$

The account here given is based on my investigations of the limestone deposits in the vicinity of Enterprise during 2 weeks in 1931, in continuation of the brief reconnaissance made by Richards and me in 1930.

\section{GEOGRAPHY}

The Wallowa Mountains are a fault block or horst about 50 miles long in a northwest direction and from 15 to 20 miles wide. The scarp on the northeast face rises abruptly from 4,000 feet to more than 8,000 feet. On the southwest side the altitude is likewise about 8,000 feet, but the presence of an extensive bench at an altitude of about 5,500 feet, a dissected portion of the old Powder River syncline, detracts from the otherwise imposing appearance of the scarp. The range gradually drops to the level of the surrounding country in the region of the Grande Ronde Valley, to the north, and the Snake River Canyon, to the south. Dissection of the country at each end of the range has produced hills of considerable relief, which, though not structurally part of the range, are often confused with it and give it the appearance of being more extensive than it actually is.

The northeastern scarp in the vicinity of Enterprise is particularly impressive. Enterprise, the county seat of Wallowa County, lies in the narrow but fertile valley of the Wallowa River, which here flows nearly parallel to the front of the range. To the north and east a hilly lava country rises gradually toward the Snake River.

\footnotetext{
${ }^{48}$ Lindgren, Waldemar, The gold belt of the Blue Mountains of Oregon: U. S. Geol. Survey 22d Ann. Rept., pt. 2, pp. 733-747, 1901.

(9wartley, A. M., Ore deposits of northeastern Oregon: Mineral Resources of Oregon, vol. 1 , no. 8,1914 . $63952-37-9$
} 
Many of the peaks at the northern front of the range continue to the south as long ridges of uniform height. The altitudes of peaks in the center of the range are scarcely greater than those near the front and nowhere reach 10,000 feet. The scarp, which is fresh and well preserved, presents several curious features to those acquainted with the fault scarps of the Great Basin. The valleys emerging from the scarp are $\mathrm{U}$-shaped instead of $\mathrm{V}$-shaped, and there is very little development of alluvial fans.

Glaciation of the Wallowa Mountains has left many evidences. The most striking of these is the great terminal moraine that dams the Wallowa River to form Wallowa Lake, nearly 4 miles long. The Lostine River emerges from the range in a U-shaped valley at nearly the level of the Wallowa River. The valleys of the Lostine River, Hurricane Creek, and the Wallowa River within the range are remarkably straight. Along their sides are many lateral mo. raines, and along their bottoms large polished mounds of bedrock, or roches moutonnées, are common. Ascending any of the valleys one encounters falls, the results of glacial treads or steps. The interfluves are cut back into arêtes, and from the cirques along their sides streams plunge over steep slopes or falls to the valley bottoms. At the heads of the streams lake basins are common. In the central part of the range practically no portion has escaped glaciation, and many of the peaks have been sharpened to horns by the action of the ice. The fact that much of this region is in or above the upper timber zone and very picturesque has made it a popular vacation land, though its relative inaccessibility precludes any great number of visitors.

\section{ACCESSIBILITY}

This region is served by a branch line of the Union Pacific system, which follows the Grande Ronde River north from the main line at La Grande to its junction with the Wallowa River, which it follows south and east to Joseph. The greater part of the freight now hauled on this line consists of livestock and dairy products, the logging industry having greatly diminished.

This region is also served by a highway that connects Joseph and the other towns of the region with La Grande. Roads leading northeast to Idaho are poor and carry but little traffic.

\section{GEOLOGY}

Plate 13 indicates in a rough way the distribution and structure of the rocks but is of the reconnaissance type and is accurate only in its larger features. 
The oldest rocks in this part of the Wallowa Mountains comprise a thick series of slates, sandstones, and limestones, which occupy a large area between the Lostine River and the West Fork of the Wallowa River. This series is best exposed on the Lostine River on the west side of Traverse Ridge. Here about 4,000 feet of sediments striking nearly north and dipping at very low angles to the east are exposed. The lowest part along the river consists of about 500 feet of sandstones and slates, altered in places to quartz-mica schists along the contact with the granodiorite. Above these rocks is 300 to 500 feet of limestone, which forms a prominent cliff along the east wall of the Lostine River Canyon. Above the limestone slates and sandstones continue to the top of the ridge.

Of direct economic interest is the limestone member of the series. In the northern part of this area, on the northeast face of the Wallowa Mountains in sec. 19, T. 2 S., R. 44 E., the limestone bed, which along the Lostine River is composed of fine granular crystalline limestone, appears in nearly its original state as a dense sootyblack rock. At this point the distance from the nearest granodiorite is about 3 miles. Along the Lostine River and Hurricane Creek and on Tunnel Mountain between Hurricane Creek and the West Fork of the Wallowa River the limestone maintains a very even thickness. Along the Lostine River it is metamorphosed to a fine granular gray rock, but on Hurricane Creek and Tunnel Mountain the original sooty-gray color and fine bedding are well preserved. On Hurricane Creek in T. 3 S., R. 44 E., and the undivided township to the south there is a huge body of crystalline limestone formed of closely folded beds striking about N. $30^{\circ} \mathrm{W}$. and standing nearly vertical. In this body, which occupies nearly 9 square miles, there are small bodies of the sandstones and slates, which indicate a complicated structure. This body of limestone, to judge from the sharp break with the prominent bed to the north, is not a lenticular portion of that bed but a local thickening caused by forces connected with the intrusion of the granodiorite.

\section{IGNEOUS ROCKS}

Basio dike rocks (Jurassic?).-Intrusive into the Triassic sediments is a series of dike and stock rocks which are well exposed on the northeast slope of the Wallowa Mountains between Hurricane Creek and Wallowa Lake. These rocks were not studied in any detail, and their full significance is not known, but they are considered to represent a post-Triassic series of volcanics. On the West Fork of the Wallowa they are well exposed. Here rocks of diabasic 
character, but considerably altered, intrude the sandstones and slates of the older sedimentary series in such a profusion of dikes as to make an irresolvable mass. In many places sills follow the bedding of the sediments and can with difficulty be distinguished from them. On Hurricane Creek the representatives of this series seem to be large stocklike masses of andesite porphyry.

In this region the quartz diorite, which is of Upper Jurassic or lowermost Cretaceous age, intrudes this series, thus establishing the age of these dike rocks as Upper Jurassic or older. No rocks of similar age are known with which this series can be compared. Most of the volcanic rocks connected with the Triassic rocks are flows interbedded with the sediments. Dike rocks that may be of similar age to these rocks occur on Connor Creek in the Snake River region.

Quartz diorite.-The main mass of the Wallowa Mountains is composed of a quartz-diorite batholith in which the limestone deposits described in this report, as well as the other areas of sediments, are merely roof pendants of a once extensive cover, now eroded away.

Because of the high altitude, severe climate, and glaciated condition of this region, the high country which includes most of this rock is bare. The bare rock surfaces of the mountains and their extreme ruggedness combine with the white color of the outcrops to produce the beauty for which this region is famous in Oregon. The quartz diorite itself is a light-gray rock of coarse to medium texture in which quartz, plagioclase feldspar, hornblende, and biotite mica may be easily distinguished. It varies slightly from place to place in composition and also in texture. Here and there are dikes of aplite, a fine-grained white rock formed of quartz and feldspar, as well as dikes of a dark hornblende-bearing rock.

Although the quartz diorite is not intrusive into rocks of a definite age, its similarity to other quartz diorite masses of eastern Oregon and its unaltered condition suggest that it is related to the postJurassic pre-Cretaceous quartz diorites of the Pacific coast province.

Columbia River lava.-Overlying the pre-Cretaceous rocks of the Wallowa Mountains with marked unconformity is a series of lava flows which can be traced west into the regions of the Columbia River lava. These lavas occur not only on the down-faulted block northeast of the Wallowa Mountains but also on the ridges of the range. A small patch occurs on Point Joseph, at an altitude of 9,500 feet. Other patches occur on the Hurricane Divide at altitudes between 9,000 and 9,500 feet. Ruby Peak, west of the mouth of Hurricane Creek, is capped with these lavas at 8,700 feet. Northeast and southwest of the area mapped, in the less thoroughly dissected parts of the range, the lavas are continuous with those on the other side. 
The lavas here are formed largely of flows with a few thin seams of tuffaceous material. In general they are basaltic and jointed into massive vertical columns. Locally andesitic flows occur which are sheeted parallel to the surface of the flows. Both varieties are black on fresh fracture and weather to dark reddish-brown outcrops.

Though these lavas are not interbedded with any definitely dated sediments in this region, their nature and the fact that they may be traced westward into material which is definitely dated shows them to be of the same age as other lavas referred to in this series.

\section{STRUCTURE}

The Wallowa Mountains are formed of a quartz diorite batholith which intruded pre-Cretaceous rocks in late Jurassic or earliest Cretaceous time and which was subjected to a long period of erosion in early Tertiary times. The batholith and associated rocks were nearly buried by the Columbia River lava in Miocene time before the faulting of presumably Pliocene age which gave to the Blue and Wallowa Mountains their present outlines. The structural features of this region may thus be conveniently grouped into those formed before the intrusion of the batholith, those formed during the intrusion, and those formed after the intrusion.

Structural features older than intrusion of quartz diorite.-The structure of the pre-Cretaceous rocks is best shown by the limestone bed which is so conspicuous in this region. The dominant structural feature here is a syncline, whose axis strikes about N. $30^{\circ}$ W., occupying the region between Hurricane Creek and the Lostine River. Dips in the limestone along both these streams are as much as $45^{\circ}$, but the pattern of the limestone bed on Silver Creek suggests that this syncline is but gently folded. The steep dips along the borders may be due to the intrusive bodies that bound the syncline. Though this syncline might be of earlier age than the quartz diorite intrusives, the profound effect that these rocks have exerted upon the limestones near the head of Hurricane Creek casts doubt upon the age of many supposedly prebatholithic structural features.

Structural features related to the intrusion of the quarta diorites.-The structural features connected with the intrusion of the quartz diorite are of particular interest in this region because they affect the limestone very strongly. Faults which, though easily traced in the sediments, cannot be followed into the quartz diorites occur at various places. These faults may perhaps be preintrusive, but it is quite probable that they belong to the period of crushing that accompanied the intrusions. One of these faults near the mouth of Hurricane Creek displaces a limestone bed vertically about 1,500 feet. Another near the mouth of Lake Creek displaces the 
limestones about 500 feet vertically, and a third a short distance south of the Iron Dyke ranger station, on the Lostine River, may possibly be continuous with still another to the east, on Hurricane Creek.

Although in general the sediments of this region are but little crushed or distorted, even the thin-bedded limestones, an area of limestone at the head of Hurricane Creek presents a most peculiar appearance, both in the field and on the map. This limestone has the same strike here as elsewhere and may be traced both on Hurricane Creek and on the Hurwal Divide into relatively undisturbed beds. But whereas the average thickness of the limestone as a whole is not greater than about 500 feet, this part of it attains thicknesses of as much as half a mile. Structurally the body is a closed syncline, the position of the axis being shown by a number of outcrops of tightly folded sandstone bodies that strike about N. $30^{\circ} \mathrm{W}$. The dips in the limestone are nearly vertical, and the individual beds, which are distinguishable with difficulty, are greatly distorted. The great and sudden increase in thickness of the limestone, which is elsewhere conformable with the overlying and underlying sandstones, suggests that the thickness is not due to depositional phenomena but to squeezing by the granodiorite batholith. Under the pressure of the overlying sediments and the heat of the intrusive mass it is conceivable that the limestone was squeezed from positions of greater pressure into those of lesser pressure. Among such places of lesser pressure would be the troughs of synclines and crests of anticlines. Competent beds such as the sandstones of this region would tend to open along bedding planes to receive masses of less competent rocks, like the limestones, which would thus be forced into them.

The structure of the batholithic mass of quartz diorite has not been studied. An interesting feature of this batholith is the remarkably sharp contact which it makes with the intruded rocks. Small roof pendants are scattered over the mass, but no interpenetration of beds by injection and no assimilation or granitization of the country rock have been observed along the contacts. Although the limestones are considerably marbleized near the batholith and in places contain pyrite, which has probably been introduced by the quartz diorites, no other alteration of either intrusive or intruded rock has been observed. Very little contact metamorphism can be noted along the contacts of the batholith and the limestones-so little that the small contact mineral deposits are eagerly sought and prospected for, though their size and value are both very small.

Structural features later than the quartz diorite.-After the intrusion of the quartz diorite, this region is supposed to have undergone erosion continuously throughout Cretaceous and early Tertiary time. 
It is commonly believed that no Cretaceous sediments were deposited here, and that this region was a source of much of the material deposited to the west. Cretaceous and early Tertiary formations are absent, hence it is impossible to state whether this region was folded while such sediments were being deposited elsewhere, or whether it acted as a resistant mountain bulwark by virtue of its granitic core. At the time the great floods of Columbia River lava were poured out the relief in this region was more than 4,000 feet, as shown by the thicknesses of these lavas in the Snake River Canyon and the Grande Ronde Valley. These lavas completely surrounded the old mountains and covered them with the possible exception of small isolated peaks. On plate 13 are shown small patches of these lavas which have been spared by erosion, and these form the summits of some of the high peaks of the range. Patches are not uncommon in the central part of the range, and on the south scarp beyond the mapped area, near China Gap (in the Telocaset quadrangle), lava Hows may be seen overlapping one another progressively onto the quartz diorite. Their present distribution suggests that they have been but little folded and that during the period of the folding of the Ochoco Mountains of northeastern Oregon the Wallowa Mountains resisted deformation, although the Powder River syncline and the Lookout Mountain anticline were formed in areas of less resistant rocks.

The scarp front of the Wallowa Mountains has not been studied in detail, but sufficient evidence, both geomorphic and stratigraphic, exists to prove its origin. South of Joseph, which has an altitude of about 4,400 feet, the front of the range is composed of pre-Cretaceous rocks which rise to an altitude of 9,500 feet in Point Joseph. The present relief of the range here is thus about 5,000 feet. Adding to this relief the thickness of Columbia River lava at the town of Joseph gives the displacement on the scarp. This thickness, depending on the amount of erosion at Joseph, would be between 2,000 and 4,000 feet, making the displacement in this central part of the scarp about 7,000 to 9,000 feet-a displacement comparable in magnitude to those of the Basin Ranges in Nevada.

\section{GEOMORPHIO DEVELOPMENT}

The geomorphic development of the present Wallowa Mountains dates from the laying down of the Columbia River lava in the Miocene epoch. After the deposition of these lavas erosion set in, and the range was raised along its present boundaries, perhaps in Pliocene time. In Pliocene time also the drainage system was established, and in Pleistocene time the end of the uplift came.

At the present time the Wallowa Mountains may be considered to $b_{\theta}$ in a state of maturity. All of the original surface which had 
been lifted up has now been eroded away. The remarkable uniform. ity of heights in this mountain mass, however, is not to be taken as a sign that the old surfaces have but recently vanished; it is consid. ered to be due to the protective influence of the flat-lying flows of Columbia River lava, which have been stripped away flow by flow and have now, after their nearly complete removal, left a relatively uniform system of heights and ridges. The stream system that began the removal of rock from these mountains no longer exists. The present Lostine River and Hurricane Creek follow contacts between different formations, and none of the streams are normal to the front of the range, as consequent streams generated on a fault block should be.

In this region, which is plentifully supplied with rain, the streams are perennial, and furthermore they drain into a river which flows along the base of the scarp. Conditions are thus decidedly different from those of arid regions where the stream courses are filled only during cloudbursts, and the absence of large alluvial fans is easily understood.

The superposition of a cycle of glaciation upon one of normal ero. sion has further complicated the geomorphology of this faulted range. Glaciation, which was probably of Pleistocene age and contemporaneous with that of the Cascade Range to the west, has considerably modified the topography of much of the Wallowa Mountains. In the area visited the glaciation has left particularly plain records of its progress.

The glacial cycle has but recently been interrupted, and the presence of snow the year round in years of normal precipitation indicates that with a moderate drop in temperature glaciation might recommence. At the present time the streams are attacking the forms left by the ice but have not yet succeeded in modifying them appreciably.

\section{LIMESTONE}

For convenience, the limestone deposits of the Wallowa Mountains may be divided into three groups-those on the Lostine River, those along the front of the range, and those on Hurricane Creek. These deposits are all on the same bed of limestone, which in some places is more metamorphosed than in others and which, on the upper part of Hurricane Creek, is greatly thickened by crushing. Much of the limestone on the Lostine River and Hurricane Creek contains pyrite, though the material along the front of the range and most removed from the mineralizing action of the granodiorite is quite pure. With care in quarrying pure material might be obtained on Hurricane Creek. 
R. $44 \mathrm{E}$.

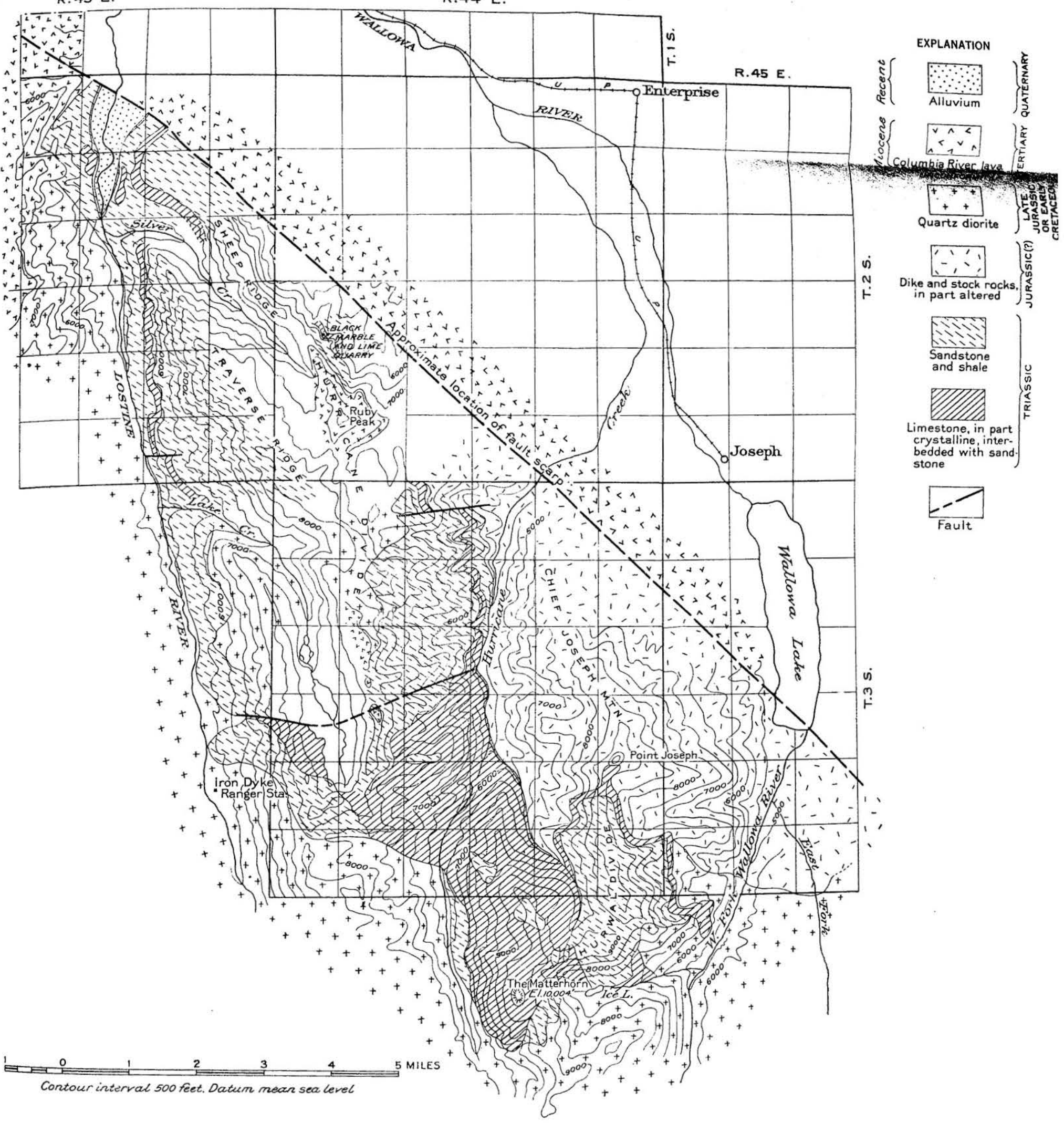

\$KETCH GEOLOGIC RECONNAISSANCE MAP OF A PART OF THE WALLOWA MOUNTAINS, WALLOWA COUNTY. 
Williams ${ }^{50}$ mentions the occurrence of limestone on the Lostine River several miles south of the town of Lostine. This locality is some 6 miles from Lostine by road and is on the west side of the river, in the $\mathrm{SW} 1 / 4$ sec. 3 , T. 2 S., R. $43 \mathrm{E}$. The limestone here is a continuation of the bed exposed on the east side of the river. It forms two prominent hills and represents a block which has slid from a higher position on the mountain side, as has a mass across the river. It consists of a thick bed of limestone interbedded with quartzites. The strike is $\mathrm{N} .45^{\circ} \mathrm{W}$. and the dip $45^{\circ} \mathrm{NE}$. A quarry has been opened, and at one time considerable amounts of limestone from it were burned for quicklime for local consumption. An analysis of the stone from this quarry was made in the laboratory of the Geological Survey with the following result:

Analysis of limestone from sec. 4, T. 2 S., R. $43 \mathrm{E}$.

[J. G. Fairchild, analyst]

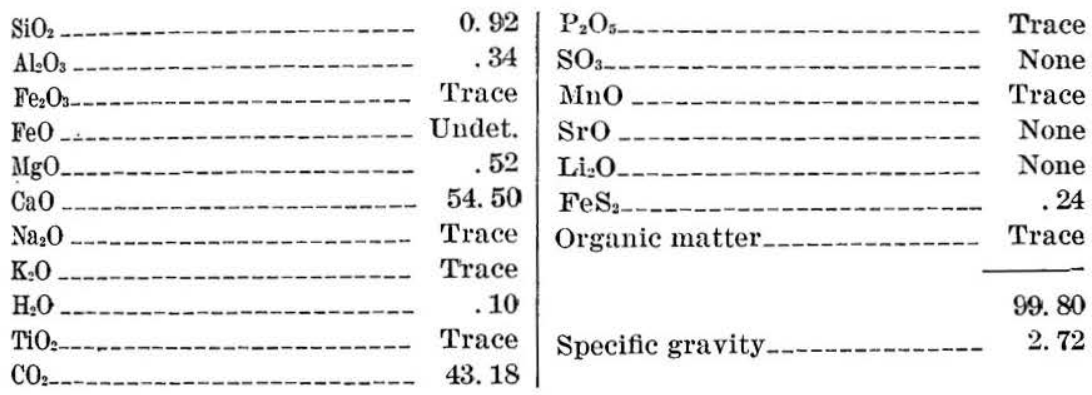

This limestone is of sufficient purity for use as cement material, but pyrite $\left(\mathrm{FeS}_{2}\right)$ is present in large enough amount to spoil it for use in high-grade quicklime. According to Dr. E. W. Lazell, of Portland, ${ }^{51}$ the burned product on slacking develops rusty spots as a result of the oxidation of the pyrite grains. At the present time the limekiln has fallen into disuse and is in ruins.

A bed of marble crops out high on the hill across the river from the quarry and swings southeastward up Silver Creek. It appears again at the mouth of Silver Creek and may be followed up the east bank of the Lostine River for nearly 6 miles. It forms a prominent cliff from 300 to 500 feet high approximately along the 5,000-foot contour. It disappears near Lake Creek, presumably being cut off by faulting and intrusion.

\footnotetext{
${ }^{60}$ Williams, I. A., Limestone deposits in Oregon: Mineral Resources of Oregon, vol. 1, no. 7 , p. 70,1914 .

s1 Oral communication.
} 
No analyses have been made of this bed except of material from the quarry above mentioned. In its various outcrops it presents the same appearance of a light-gray, finely granular marble which weathers to a coarse calcitic sand. Though large tonnages of this rock are available here, its occurrence as a cliff member overlain by great thicknesses of rock introduces many mining difficulties which, combined with the distance from a railroad, make it of little present value. Should development of cement material be undertaken the pyrite-bearing bed at the quarry on the Lostine River might better be used than this more inaccessible material.

BLACK MARBLE \& LIME CO.

The deposits along the front of the Wallowa Range on the supposed eastward continuation of the limestone exposed on the Lostine River have been examined at only one point-the Black Marble \& Lime Co.'s quarry in sec. 19, T. 2 S., R. 44 E.

This quarry is in a dense forest high on the face of the Wallowa Mountains, at an altitude of nearly 7,000 feet. It is reached by a steep, narrow road, over which limestone is hauled from the quarry to the mill. The limestone here forms no cliff, and the slope is the same as that of the face of the mountain. The quarry is in a narrow gulch above several old limekilns, which burned lime from limestone boulders taken from the stream bed.

The limestone is a dense sooty-black rock marked by scattered white splotches, possibly the remains of fossil algae. A few fossil shells were seen in it, but none of determinative value were found. The limestone is well bedded, and the strata range from 1 to 6 feet in thickness. No shaly partings were noted, the bedding being conspicuous only on weathered surfaces. The rocks strike N. $35^{\circ} \mathrm{W}$. and $\operatorname{dip} 10^{\circ} \mathrm{SW}$. The heavy forest cover and the short time available prevented any attempt to trace out the beds. According to Parks, ${ }^{52}$ the outcropping bed is from 50 to 500 feet thick and may be traced nearly 1,000 feet west of the quarry, where it grades into a gray marble.

A sample of the limestone collected in the quarry was submitted to the chemical laboratory of the Geological Survey for analysis.

${ }_{62}$ Parks, H. M., Mineral Resources of Oregon, vol. 1, no. 2, p. 30, 1914. 
Analysis of limestone from quarry in sec. 20, T. 2 S., R. $44 \mathrm{E}$.

[J. G. Fairchild, analyst]

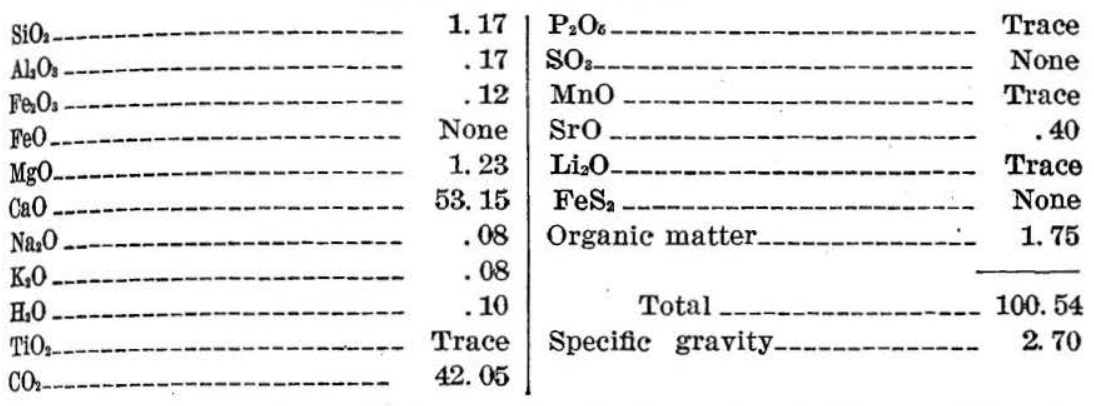

Recomputing this analysis to a basis free of volatile constituents gives the following result:
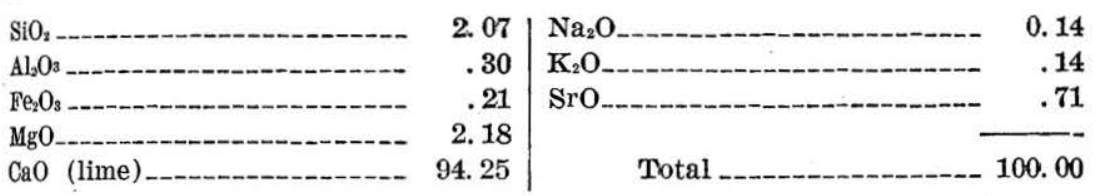

This analysis shows that burning the limestone should yield a high-calcium lime. According to Dr. E. W. Lazell, of Portland, ${ }^{53}$ this limestone burns to a superior grade of lime with a very desirable texture. The lime slacks easily and works smoothly.

This deposit is worked by a local company known as the Black Marble \& Lime Co., which was organized in February 1925 and is capitalized at $\$ 350,000$. The cost of the present plant and of the development of the property up to the time of my visit in 1931 had been $\$ 325,000$, according to the company's officers.

At the present time the face of the quarry is about 40 feet high, and to avoid the necessity of removing large amounts of overburden a tunnel has been run into the face and a large chamber mined out. The limestone is shot down, loaded by hand into cars, and dumped into storage bins. The original plans called for the erection of an aerial tram about 4 miles long to carry the limestone to the mill, but insufficient money was raised and a caterpillar tractor and trailers were used as a temporary substitute. The trailers weighed 15 tons apiece and carried 10-ton loads. They were hauled over a long, narrow, steep road 7 miles to the mill. The limestone is now hauled by 5 -ton trucks.

The mill is near Enterprise and has a capacity of about 10,000 tons of quicklime a year. Its total production to June 1931 had been about 7,000 tons. The plant consists of a weighing house

soral communication. 
where the limestone is dumped and loaded into tared cars, which carry it up an incline and dump it into any one of three vertical kilns. The warehouse is on the hillside below the kilns, and the finished product can be loaded directly into the cars.

This deposit is the most promising of those in Wallowa County. Should the proposed aerial tramway be erected and markets for the products be found on the coast, operation of the deposit might well prove profitable.

\section{HURRICANE CREEK}

The limestone beds that crop out on the face of the Wallowa Mountains at the Black Marble \& Lime Co.'s quarry reappear to the southeast on Hurricane Creek. Near the mouth of the creek the beds resemble those along the north face of the scarp, but as the contact with the granodiorite is approached they become crystalline. The marbleized limestone is greatly thickened by crushing near the head of Hurricane Creek. (See pl. 13.) In places the limestone is a pure-white marble, but no sufficiently detailed work has been done to indicate the relative amounts of the different grades of purity. An analysis of a marble near the southern part of the body is here given:

Analysis of marble from sec. 10, T. \& S., R. 44 E.

[J. G. Fairchild, analyst]

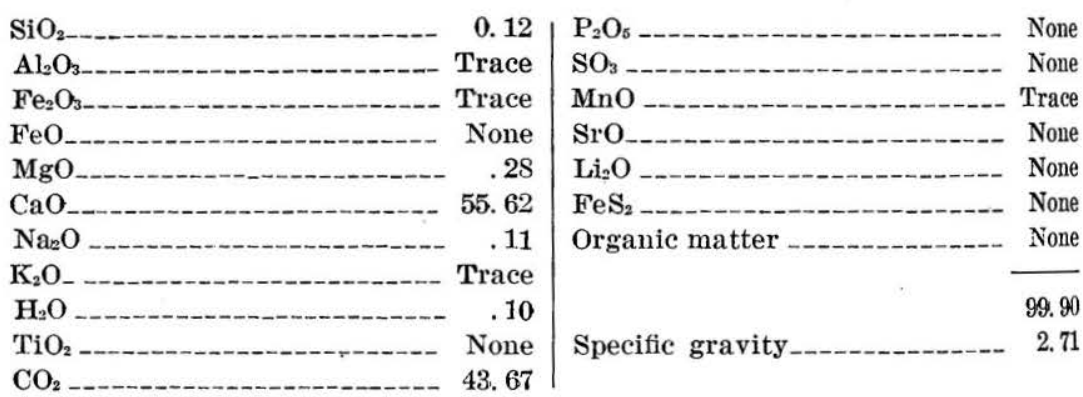

On burning, this should give a lime of the following composition:

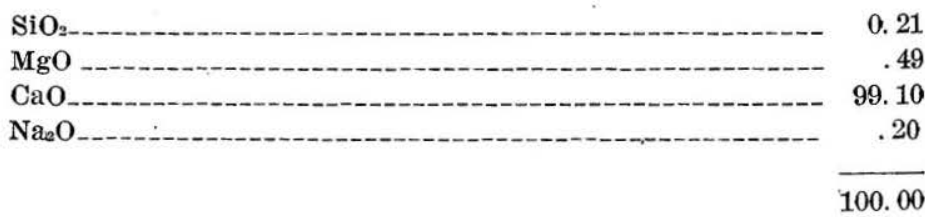

This particular material should thus furnish a very "fat" highcalcium lime. However, all parts of the deposit do not consist of such high-grade material. Samples of medium-grained gray marble collected in the SE1/4 sec. 16, T. 3 S., R. 44 E., contained numerous pyrite cubes as much as an eighth of an inch in diameter. 
The contact zone of the marble and quartz diorite was not studied in detail, but in the region of Ice Lake it was noted that no contactmetamorphic minerals had been formed in the marble. It may be assumed that aside from the development of pyrite this deposit is free of any considerable quantity of metamorphic minerals. On the basis of the area of outcrop determined as shown on the map, the tonnage of available marble above an altitude of 5,500 feet is conservatively estimated to be about $1,500,000,000$ tons.

The greater part of this deposit is held under patented placer claims granted to a group headed by Mr. E. K. Scott, of Portland, Oreg. To date no exploitation of the properties has been attempted. The tonnage of this deposit entitles it to consideration, but its relative inaccessibility makes its utilization a matter of more interest for the future than the present. If enough building or ornamental marble of sufficiently high grade should be discovered to command a market, corresponding development might be expected.

\section{BAKER COUNTY}

Limestone occurs at many localities in Baker County in lenticular bodies interbedded in the Paleozoic and Mesozoic argillites and greenstones. Though many small bodies have been found at widely separated localities, there are only two large belts of these deposits. An extensive and thick bed of Triassic limestone occurs on Eagle Creek, in the northeastern part of the county, and a series of limestone lenses extends across the southern part of the county. These include the large and easily accessible deposits along the Snake River in T. 11 S., R. 45 E.; those in the northern part of T. 12 S., R. 44 E.; those in the northern part of T. 12 S., R. 43 E.; and the inaccessible deposits in T. 12 S., R. 42 E., on the Burnt River. The most important deposit in eastern Oregon, industrially, is that of the Oregon Portland Cement Co., at Lime, on the lower part of the Burnt River. This deposit is one of a series of lenticular bodies shown on Lindgren's map ${ }^{54}$ as extending north and east across the Snake River as far north as Mineral, Idaho.

Though large amounts of limestone in Baker County are available for future use, only five of the larger and more accessible deposits are here described.

\section{EAGLE CREEK}

Limestone crops out on Eagle Creek, on the southwest slope of the Wallowa Mountains, in thick and extensive beds. This occurrence was noted by Lindgren, ${ }^{55}$ who has described the limestone and the associated rocks in some detail.

\footnotetext{
Lindgren, Waldemar, op. cit. (22d Ann. Rept.), pl. 44.

${ }^{\text {s }}$ Idem, pp. 580-581, pp. 734-736.
} 
The limestone forms beds from a few feet to more than 220 feet thick. It is interbedded with a series of black shales and sand. stones, consolidated but very little altered. Both the limestone and the shales are fossiliferous and contain an abundant Triassic fauna. These rocks were studied by $\boldsymbol{R}$. W. Richards and me in 1930 in the region of Martin Bridge and Paddy Creek. The thicker beds form a prominent outcrop which extends along Eagle Creek for a considerable distance as a white cliff. According to Lindgren's map, the limestone crops out on the east fork of Eagle Creek for 9 miles north of its junction with Paddy Creek.

The limestone in the vicinity of Martin Bridge is not crystalline in the smaller beds, but in the thick beds it is partly recrystallized. It ranges in color from black to light gray and in bedding from finely laminated to massive. Much of the rock is impure, containing large amounts of shaly and sandy material. The following analysis made in the laboratory of the Geological Survey shows the composition of a sample collected along the road about 2.8 miles above Martin Bridge, in sec. 8, T. 7 S., R. 43 E.

Analysis of limestone from sec. 8, T. 7 S., $R$. 44 $E$.

[J. G. Fairchild, analyst]

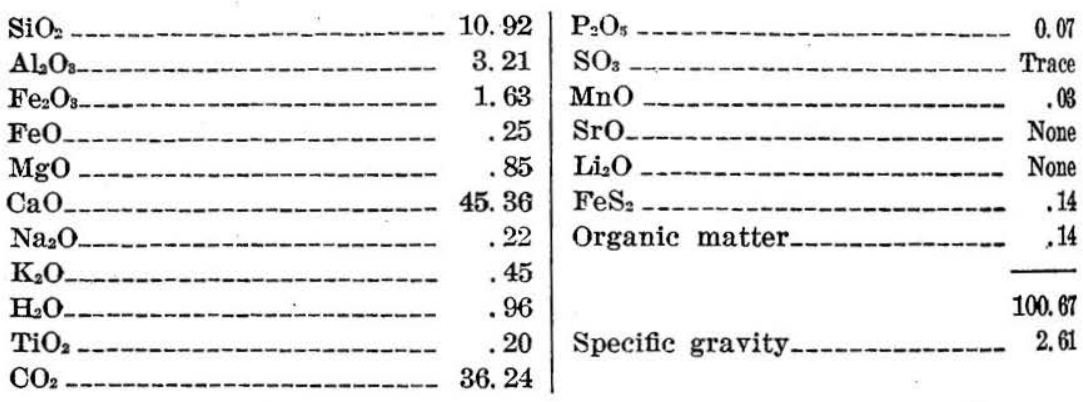

This is a rather impure limestone, unfit for burning. It might, however, be of use for making cement. In view of the distance of the deposit from railroads it is not likely to be of any economic importance for a long time, despite its large size.

\section{CONNOR CREEK}

A large deposit of very pure limestone occurs on Connor Creek, in the Snake River Canyon, about midway between Huntington and Robinette. This deposit is close to the Robinette branch of the Oregon Short Line Railroad but is not yet developed, despite its purity and size. A brief visit was paid to this deposit in 1930 by R. W. Richards and me, and in 1931 I spent 4 days examining it in 
greater detail. The deposit has been mentioned by Lindgren, ${ }^{\text {s6 }}$ Swartley, ${ }^{57}$ and Williams ${ }^{58}$ but has not hitherto been described in any detail.

\section{GENERAL FEATURES OF DISTRICT}

The Snake River in the region between Huntington and Robinette flows in a narrow canyon bounded by steep though not precipitous walls carved by streamlets into smooth rounded forms, which rise from the river, here about 2,000 feet above sea level, to altitudes of 4,000 to 5,000 feet. In distinct contrast to these smooth forms is a chain of cliffs, sharp knobs, and precipitous gorges which cut across the Connor Creek area several miles from the mouth of the creek in a direction about $\mathrm{N} .60^{\circ} \mathrm{E}$. These forms, which can be seen from the road along Snake River, are formed of the limestone. Connor Creek is about 3,500 feet in altitude at the deposit, and the highest point in the limestone is 6,263 feet on the divide between Fox and Connor Creeks. The steepness of the canyon in which Connor Creek flows is shown by its descent from 3,500 feet to 2,000 feet, at its mouth, in a distance of 3.1 miles. About $1 \frac{1}{2}$ miles southwest of Connor Creek and parallel to it is Fox Creek, another perennial stream which flows in a narrow canyon similar to that of Connor Creek and which likewise flows across the limestone in a deep, precipitous gorge. To the north and west the general altitude of the ridges and summits is from 5,500 to 6,500 feet. Lookout Mountain, a prominent conical peak just west of the mapped area, is 7,123 feet above sea level and the highest point in the region. Sugarloaf Mountain is formed of a remnant of the once extensive Columbia River lava and presents a distinctive stepped appearance due to the flows of lava from which it has been carved. In some places these flows have weathered to remarkably flat-topped ridges, as in sec. 22, T. 11 S., R. 45 E.

This deposit is 20 miles from Huntington by a poor road. It is 16.4 miles from Huntington to the mouth of Connor Creek, 3.1 miles up Connor Creek to the forks, and about half a mile by a now impassable road to the main limestone body. Transportation for limestone or finished lime products is available over the Robinette branch of the Oregon Short Line Railroad, which follows the Snake River. Development of the limestone would involve the building of at least 4 miles of track to connect this branch.

\footnotetext{
${ }^{5}$ Lindgren, Waldemar, The gold belt of the Blue Mountains of Oregon: U. S. Geol. Survey 22d Ann. Rept., pt. 2, p. 756, 1901.

${ }^{57}$ Swartley, A. M., Ore deposits of northeastern Oregon: Mineral Resources of Oregon, vol. 1 , no. 8 , p. $211,1914$.

Williams, I. A., Limestone deposits in Oregon: Mineral Resources of Oregon, vol. 1, no. 7 , p. $68,1914$.
} 


\section{GEOLOGY}

The limestone deposit of Connor Creek consists of a large irregular-shaped lenticular body' of limestone interbedded in a series of steeply dipping schists and slaty rocks. Intrusive into this series are some basic dike rocks, now greatly altered, and the Lookout Mountain quartz diorite batholith. These rocks, which are all of pre-Cretaceous age, are overlain by some remnants of once extensive flows of the Columbia River lava, of Miocene age. The distribution of these rocks is shown on plate 14 .

TRIASSIC ROCKS

The oldest rocks in this region comprise a series of argillaceous sediments and limestones which have been altered to schistose and slaty rocks and marbles. These rocks have been mapped by Lind. gren ${ }^{59}$ as Triassic.

The argillaceous sediments of this series form the greater part of the Snake River Canyon between Huntington and Robinette. Near Huntington they are underlain by the older greenstones, and near Robinette they are covered by nearly 3,000 feet of Columbia River lava. They are soft, easily weathered rocks, and the land forms carved from them are smooth and rounded, marred only by sporadic resistant beds or dikes. A thick section of these rocks occurs in Connor Creek Canyon, where for a distance of about 3.6 miles along the creek they dip $30^{\circ}-60^{\circ} \mathrm{NW}$. and strike in general about N. $60^{\circ}$ E. Outcrops are not numerous, and it could not be decided whether the apparent thickness of more than 5,000 feet is actual or due to repetition of beds by folding. In Triassic formations of the Pacific coast region thicknesses of more than 10,000 feet are not rare, and in view of the fact that the prominent limestone member of this series is not repeated, the beds on Connor Creek may represent an actual thickness.

The rocks of this series are composed largely of black shales which have been compressed and altered until they resemble slates and even schists, but no slaty cleavage appears to have been developed across the bedding of the rock. Here and there are slaty green rocks, similar to metamorphosed tuffs. Sandstones occur sparingly and are usually silicified. Their superior resistance to erosion causes them to form jagged outcrops on the otherwise smooth hillsides.

A belt of limestone lenses extends from the Idaho side of the Snake River opposite Soda Creek across the heads of Connor, Fox, and Hibbard Creeks and, with interruptions, as far west as Gold Hill, on the Burnt River. These lenses are very irregular in shape

\footnotetext{
${ }^{50}$ Lindgren, Waldemar, The gold belt of the Blue Mountains of Oregon: U. S. Geol. Survey 22d Ann. Rept., pt. 2, p. 579, 1901.
} 


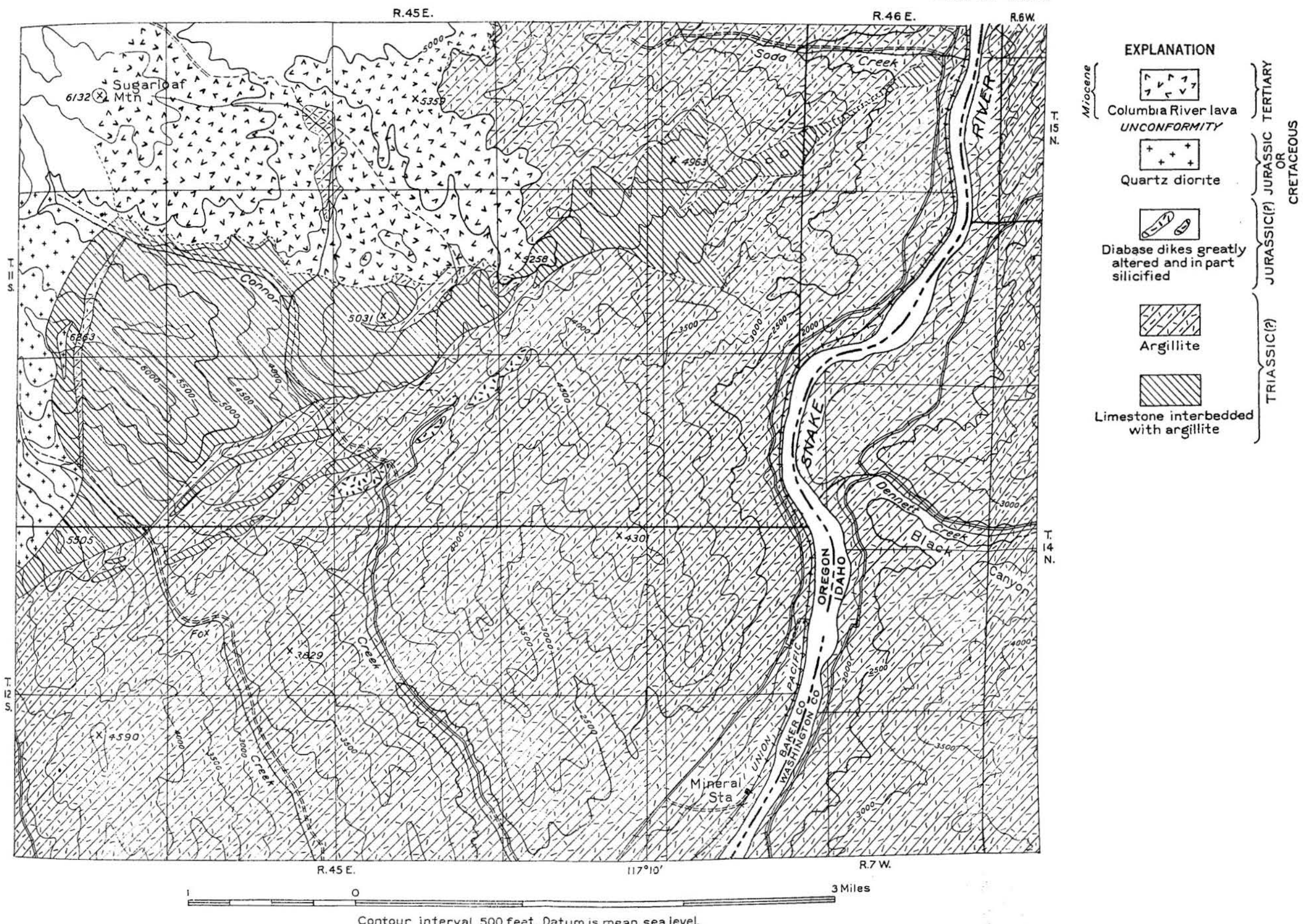

GEOLOGIC MAP OF LIMESTONE DEPOSIT OF CONNOR CREEK DISTRICT, BAKER COUNTY. 
and size. The largest lies between the heads, of Fox and Connor Creeks and occupies parts of secs. 27, 28, 29,32, 33, and 34, T. 11 S., R. 45 E. The total area of this body is about 2.4 square miles, more than treble the size of the other lenses in the chain. It is roughly triangular. Along the southeastern edge it is in contact with the argillites, on the north the limestone is covered by the later Tertiary lavas, and on the west the limestone is intruded by the quartz diorite of Lookout Mountain. Along the contact with the argillite the limestone dips from $60^{\circ} \mathrm{N}$. to nearly vertical. The general parallelism of the limestone and the argillites suggests conformity, and so do the interbedded argillites near hill 6263 on the Connor-Fox Creek divide. Smaller bodies that occur on this divide south of the main lens also appear to be interbedded in the sediments of this series.

\section{IGNEOUS ROCKS}

Dike rocks.-Several small lenticular masses of greatly altered dike rocks have been found in sec. 34, T. 11 S., R. 45 E. These rocks form prominent reddish-brown outcrops on the hillside, but the rock on fresh fracture is white. It is crystalline and very heavy, but soft enough to be easily scratched by the finger nail. This rock has not been examined under the microscope but is considered to be formed of talc. A cut in the rocks in the westernmost body showed that the cores of many of the joint blocks are composed of heavy black rock similar in general appearance to a diabase. This is likewise altered, but the composition of the alteration products and the structure of the outcrops show that these rocks are representative of basic dikes that intruded the argillites and with them were subjected to the forces and intrusions that resulted in alteration.

Later alteration is shown by the easternmost body of this rock which has been extensively silicified to a hard, tough, light-colored material that little resembles the original rock.

Quartz diorite.-A large body of quartz diorite has been mapped by Lindgren ${ }^{60}$ in the vicinity of Lookout Mountain. This rock forms a batholith, intrusive into the Paleozoic and Triassic argillites of the surrounding country. It is in general a light-gray mediumgrained rock with a granitic texture. Under the hand lens it is found to contain quartz, plagioclase feldspar, hornblende, and small amounts of biotite mica. The western boundary of the limestone of the Connor Creek area is marked by the intrusion of this diorite. Along the contact the limestone has been considerably recrystallized, samples from hill 6263 , in sec. 29 , T. 11 S., R. 45 E., being a coarsely crystalline white marble. The diorite is glassy for a few inches from the contact and is fine-grained for a distance of several feet.

${ }^{\infty}$ Lindgren, Waldemar, op. cit. (22d Ann. Rept.), p. 586. $63952-37-10$ 
The contact-metamorphic effects on the limestone, however, are very slight. On Fox Creek the limestone has been comparatively little affected, even at the contact. It is crystalline but not as much so as material several hundred feet from the contact. It is gray and darker-colored than material some distance from the contact. No contact-metamorphic minerals could be seen, either silicates or sulphides.

Columbia River lava.-Overlying the eroded edges of the preCretaceous rocks is a thick series of basaltic lavas which can be traced into this area from the John Day and Columbia River regions. These lavas in the Powder River and Burnt River Valleys show the same conformable relation to the overlying lake beds as elsewhere. In the Connor Creek area they are represented only by remnants which form some of the flat ridges and peaks, such as Sugarloaf Mountain. Farther north, at Robinette, in the Powder River syncline, 3,000 feet of the lavas are exposed. Here, as elsewhere, the series is formed almost exclusively of flows. Between the flows there is a little scoria and in places there are small amounts of a bright-red rock-old soil baked by the overlying flow. The lavas are basalts and hypersthene andesites. The basalts crop out in typical cliffs with columnar jointing, but the andesites are commonly sheeted parallel to the surface of the flow.

\section{STRUCTURE}

The structure of the rocks on Connor Creek has the appearance of a monocline intruded by a batholith. The structure in the argillites, superficially at least, seems to be rather simple, but the lentic.ular structure of the limestones is rather complicated.

Though the argillites appear to be little deformed, the limestones show great deformation. The structure of the main limestone body is particularly interesting. The dips in this body are essentially vertical, though they vary from about $70^{\circ} \mathrm{SE}$. to about $50^{\circ} \mathrm{NW}$. along the contact with the argillites. The contact with the argillites strikes about N. $60^{\circ}$ E., but just to the east of the contact with the quartz diorite a few beds of infolded argillaceous rocks show the strike along that margin to be nearly north. This same strike may be found in the limestones along the divide between Fox and Connor Creeks. Measurements normal to the southeast contact of the limestone show the thickness in the Fox Creek gorge to be less than half a mile, whereas a maximum thickness of more than a mile is attained only a mile to the northeast.

A consideration of the patterns of the limestone outcrops, their structure, and the history of the rocks leads to the conclusion that their present sizes and shapes are due to squeezing out of a limestone bed, uniform in thickness and of great extent, during a period of 
folding and intrusion. Limestones under pressure act differently from other rocks. Though compression increases the strength of a sandstone or conglomerate, a limestone under similar conditions may flow. While the siliceous argillites were being compressed and faulted, the limestone beds were squeezed, redistributed, and localized in places where pressure was least. In some places they followed the intricately folded or faulted contact with the argillites, as on the ridge south of Soda Creek, but elsewhere they were compressed longitudinally into thick lenses, such as the main deposit between Fox and Connor Creeks.

\section{IIMESTONE}

OCOURRENCE

The limestone of the Connor Creek region is one of the largest bodies of easily accessible high-grade limestone in eastern Oregon. It is a crystalline gray to white rock without noteworthy silicification or clayey or sandy beds. On Fox Creek there are small areas of material which approach a high-grade marble in appearance. Hand specimens show that the limestone is very uniformly pure, but only one chemical analysis has been made. This was done in the laboratory of the Geological Survey.

Analysis of limestone from sea. 28, T. 11 S., R. $45 \mathrm{E}$.

[J. G. Fairchild, analyst]

\begin{tabular}{|c|c|c|c|}
\hline $\mathrm{iO}_{2-}$ & None & $\mathrm{P}_{2} \mathrm{O}_{-}$ & None \\
\hline $\mathrm{Al}_{2} \mathrm{O}_{3}-$ & None & Undete & rmined \\
\hline $\mathrm{Fe}_{2} \mathrm{O}_{3}$ & None & MnO & Trace \\
\hline $\mathrm{eO}$ & None & $\mathrm{SrO}$ & None \\
\hline $\mathrm{MgO}$ & 0.52 & $\mathrm{Li}_{2} \mathrm{O}$ & None \\
\hline 0 & 55.65 & $\mathrm{FeS}_{2}$ & None \\
\hline $\mathrm{a}_{2} \mathrm{O}$ & Trace & Organic matter & None \\
\hline 0 & Trace & & \\
\hline 0 & None & & 99.84 \\
\hline $\mathrm{O}_{2}$ & None & Specific gravity & 2.68 \\
\hline
\end{tabular}

A conservative estimate gives a total reserve of $300,000,000$ long tons based on the outcrop above an altitude of 3,500 feet. . Whether all this material is as pure as the sample analyzed is not known, but the appearance of the different specimens collected suggests that the whole deposit is of an unusually high degree of purity.

\section{DEVELOPMENT}

At one time an attempt was made to use the crystalline limestone on Fox Creek for dimension stone, and a large marble saw was set up. The ruins of the buildings and the saw still remain. Several claims have been staked out on Fox Creek on the limestone, but no quarrying or mining has been done. 


\section{CONCLUSIONS}

In the development of limestone in eastern Oregon this deposit is one that deserves careful consideration. The deposit is large and of high quality. The distance from the railroad, a little more than $31 / 2$ miles, is an obstacle but is not great enough to prohibit development should prices of limestone or lime products in Portland and that vicinity warrant shipping large tonnages.

\section{SISLEY CREEK}

A large deposit of limestone occurs on Sisley Creek in sec. 3, T. 12 S., R. 44 E., about 5 miles from Weatherby and the Union Pacific Jine in the Burnt River Canyon. It is accessible from the railroad and highway by a narrow mountain road, which rises from an altitude of about 2,400 feet at the railroad to 3,600 feet at the deposit.

The limestone occurs as a series of lenses which range from 50 to 300 feet in thickness. They stand nearly vertical and strike in a general westerly direction. They are interbedded with siliceous sediments, which approach quartz-mica schists and quartzites in appearance. The limestone lenses and interbedded sandstones and quartzites total more than a mile in thickness, extending north and south of the boundaries of sec. 3, T. 12 S., R. 44 E. The deposit is apparently a continuation of the same series of lenses represented by the deposit of Connor Creek, to the east.

The limestone is entirely recrystallized and ranges in color from light gray to white and in texture from fine-grained to coarse granular. Weathering of the more coarsely crystalline lenses gives a coarse calcitic sand. Most of the lenses contain siliceous material in large amounts. A sample taken from one of the lenses in the northern part of the deposit was analyzed in the laboratory of the Geological Survey with the following results:

Analysis of limestone from sec. 3, T. 12 S., R. 44 E.

[J. G. Fairchild, analyst]

\begin{tabular}{|c|c|c|c|}
\hline $\mathrm{SiO}_{2-2}$ & 11. 21 & $\mathrm{P}_{2} \mathrm{O}_{5} \ldots$ & 0.05 \\
\hline $\mathrm{Al}_{2} \mathrm{O}_{3} \ldots$ & .15 & $\mathrm{SO}_{3} \ldots$ & Trace \\
\hline $\mathrm{Fe}_{2} \mathrm{O}_{3}$ & .17 & $\mathrm{MnO}_{--}$ & .02 \\
\hline $\mathrm{FeO}$ & None & SrO_- & None \\
\hline $\mathrm{MgO}_{--}$ & .52 & $\mathrm{Li}_{2} \mathrm{O}_{-}$ & Trace \\
\hline $\mathrm{CaO}$ & 49. 82 & $\mathrm{FeS}_{2}$ & Trace \\
\hline $\mathrm{Na}_{2} \mathrm{O}$ & .21 & Organic matter & Trace \\
\hline $\mathrm{K}_{2} \mathrm{O}_{-}$ & Trace & & \\
\hline $\mathrm{H}_{2} \mathrm{O}_{---}$ & Trace & & 100.54 \\
\hline $\mathrm{TiO}_{2}$ & Trace & Specific gravity & 2.70 \\
\hline $\mathrm{CO}_{2-1}$ & 38.39 & & \\
\hline
\end{tabular}


This analysis shows silica to be the chief impurity. The amount is too great to permit use of the rock for lime burning, but it might be used for cement manufacture.

The lenses have a combined area of more than 320 acres. If a minimum minable thickness of 60 feet is assumed, an estimate of $60,000,000$ long tons is obtained. It is possible that some of this is purer than that represented by the analysis given above.

\section{NELSON}

A large deposit of limestone occurs at Nelson, a siding on the Union Pacific line in the Burnt River Canyon, 3 miles south of Durkee. The limestone is a lenticular body in a series of argillites, quartzites, and cherts which have been mapped by Lindgren ${ }^{61}$ as Paleozoic but which appear to be western continuations of sediments exposed on Connor and Sisley Creeks and supposed to be Triassic. The limestone consists of a number of beds about 40 feet in average thickness which have been squeezed between argillites, quartzites, and cherts. The strike is N. $65^{\circ} \mathrm{E}$. and the dip $63^{\circ} \mathrm{NW}$. The limestone is nearly black, crystalline, and extensively silicified. The beds are variable in thickness, owing to the crushing between the interbedded clastic rocks. The total thickness of the limestone and associated beds is about 1,500 feet, and the outcrop is limited to Gold Hill, on the northeast side of the river. On the south side the only evidence of limestone is a large tufa cone built by a sulphur spring, now cool, on an old river bench.

In the field considerable difficulty was found in picking out a pure bed in the limestone. A specimen taken from the old quarry was analyzed in the laboratory of the Geological Survey, with the following results :

Analysis of limestone from sec. 4, T. $12 \mathrm{~S} ., \mathrm{R} .43 \mathrm{E}$.

[J. G. Fairchild, analyst]

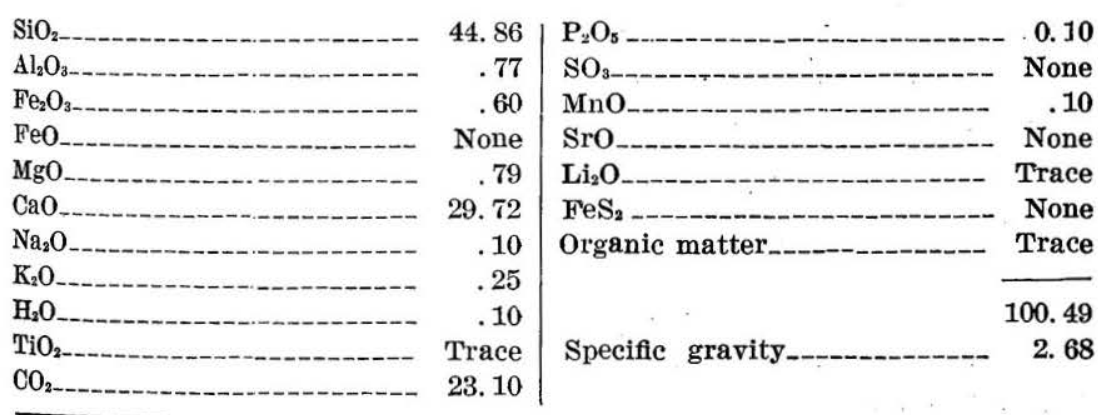

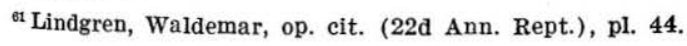


The quarry from which this specimen was taken is now abandoned, probably because of the impurity of the limestone. The high content of silica which is present as quartz ruins it for use in lime burn. ing, but it might be used in cement manufacture. Although a minimum of $50,000,000$ tons is available in a very accessible location, the siliceous nature of the deposit will doubtless prevent its development.

\section{LIME}

The most productive developed limestone deposit of eastern Oregon is that at Lime, on the Burnt River about 5 miles above Huntington, Baker County. This deposit was examined by J. C. Reed and H. G. Mitchell, of the Geological Survey, during the investigation of the ore deposits of eastern Oregon in the season of 1930. The following report is based on their manuscript and map, which have been made available to me. Acknowledgments are due to Mr. J. M. McClenahan, superintendent of the Oregon Portland Cement Co.'s plant at Lime, for permission to investigate the company's property, and to both Mr. McClenahan and Mr. Lugnet, chemist, for their many courtesies and information about the plant.

This deposit is restricted to an irregular area of a little more than 1 square mile, on the steep slopes of the Burnt River Canyon. In this region the Burnt River maintains a more or less southeasterly course through a narrow tortuous canyon. The flood plain is narrow, and above it the hillsides rise with slopes of about $30^{\circ}$ from 1,000 to 3,000 feet above the stream. The hills are covered with a thin growth of sagebrush and grass, and in favored nooks small junipers grow. Rainfall in this region is low, and snow in winter amounts to only a few inches. This deposit is very advantageously located with respect to transportation, as it is on the main line of the Union Pacific Railroad, which follows the Burnt River on its way from the Snake River Plain to Baker.

\section{GEOLOGY}

The rocks at Lime comprise limestone, volcanic tuffs, and tuffaceous shales, which Lindgren ${ }^{62}$ considered of Triassic age. Intruding the rocks are numerous basic dikes which are believed to bo related to the flows of the Columbia River lava. The distribution of these rocks is shown on plate 15 .

\section{TRIASSIO LIMESTONE}

The limestone is the oldest rock shown on plate 15 . It is about 2,000 feet thick and the beds weather to form great rocky slopes and

Lindgren, Waldemar, The gold belt of the Blue Mountains of Oregon: U. S. Geol. Survey 22d Ann. Rept., pt. 2, p. 579, 1901. 
cliffs. On weathered outcrops the stone is a light gray, but the fresh rock is bluish gray or white, the color depending on the degree of marbleization. Individual beds range in general from 4 to 5 feet in thickness, though many thin shaly beds are present and also some very thick beds. The areal pattern is extremely irregular and because of numerous small faults does not correspond with the strike or dip, which are N. $60^{\circ}$ E. and $45^{\circ} \mathrm{NW}$., respectively.

The limestone is largely recrystallized and has yielded no determinable fossils, though traces of what appear to be organic remains can be seen on some of the weathered outcrops. The age of the limestone is not definitely known. Lindgren's age assignment was based on the low degree of deformation of these beds as compared with the Paleozoic strata.

\section{VOLCANIC ROCKS}

Lying with apparent conformity on the limestone and containing interbedded limestone lenses is a series of volcanic tuffs and tuffaceous shales which extends some distance up the river and is at least as thick as the limestone-that is, 2,000 feet. These rocks do not resemble the Tertiary tuffs in general appearance but are considerably altered. The tuffs, which pass locally into agglomerates, are massive, structureless red and green rocks, whereas the shales are bright red and somewhat slaty.

Examination under the microscope shows that these tuffs are composed chiefly of fragments of siliceous lavas, quartz keratophyres. The tuffaceous shales also contain much pyroclastic material.

TERTIARY ROCKS

Many basalt dikes occur in this region. They intrude the limestone and the volcanic rocks but are not metamorphosed. Their freshness suggests a Tertiary age, as does also the presence of once extensive Miocene lava flows for which they may have been feeders.

These dikes weather dark brown and in many places show spheroidal weathering. The fresh rock is a medium-grained dark-green to black basalt. Under the microscope the feldspar was determined to be labradorite. The dikes range from a few inches to more than 300 feet in thickness and some are more than 1,000 feet long. A rather poorly exposed dike in the north-central part of the area apparently passes into a sill or perhaps a surface flow. Many of the dikes follow faults oriented about N. $30^{\circ} \mathrm{W}$.

\section{QUATERNARY DEPOSITS}

Thin deposits of terrace gravel and recent alluvium cover the old river benches and the present flood plain of the Burnt River. These 
deposits obscure a small part of the canyon bottom but are thin and of no great extent.

\section{STRUCTURE}

The structure of this deposit is that of a series of steeply dipping beds with an average strike of $\mathrm{N}$. $60^{\circ} \mathrm{E}$. and a dip of $45^{\circ} \mathrm{NW}$, which has been complexly faulted and then intruded by numerous basalt dikes. The irregular outline of the limestone mass is due to numerous faults of considerable throw but small length, which are older than the Miocene (?) dikes. Most of these faults trend $\mathrm{N} .30^{\circ} \mathrm{W}$., and several in the northeast corner of the area are curved.

\section{LIMESTONE}

The limestone of this deposit is sufficiently pure for use in the manufacture of cement. A series of analyses furnished by $\mathrm{Mr}$. Lugnet, of the Oregon Portland Cement Co., showed that the amount of magnesium present was variable, ranging from 0.66 to 17.00 percent. The distribution of samples with high magnesium content was not regular. The following analysis gives an idea of the composition of the material used here for cement manufacture:

Analysis of limestone from quarry at Lime

[Mr. Lugnet, Oregon Portland Cement Co., analyst]

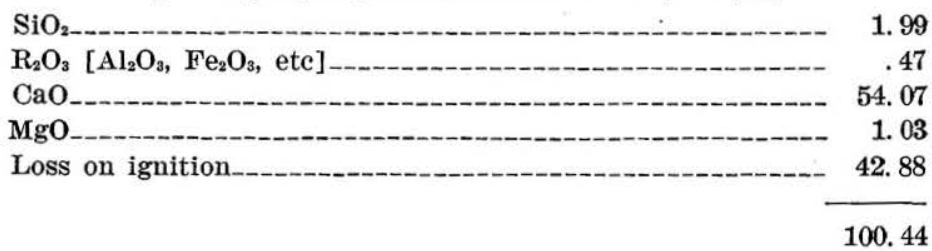

This deposit is large and well located. No estimate of tonnage is given, because of lack of detailed knowledge of the composition of the deposit.

\section{MINING COMPANIES}

The Oregon Portland Cement Co., of 321 East Madison Street, Portland, Oreg., owns 640 acres in secs. 26, 27, 34, and 35, T. 13 S., R. 44 E. It also owns a small area near Durkee, 18 miles above Lime, where a quarry is maintained to supply "clay" for the cement plant at Lime.

The mills are on the Burnt River on the hillside above the tracks of the Union Pacific Railroad. Spur tracks allow hauling of the "clay" from Durkee to the mill. The quarry is in a canyon west of the mill and across the river and is completely mechanized. The limestone is broken up by powder and slides down bedding planes to the quarry floor, where it is loaded onto quarry cars by a gasoline shovel and then dumped into loading bins from which it is taken 


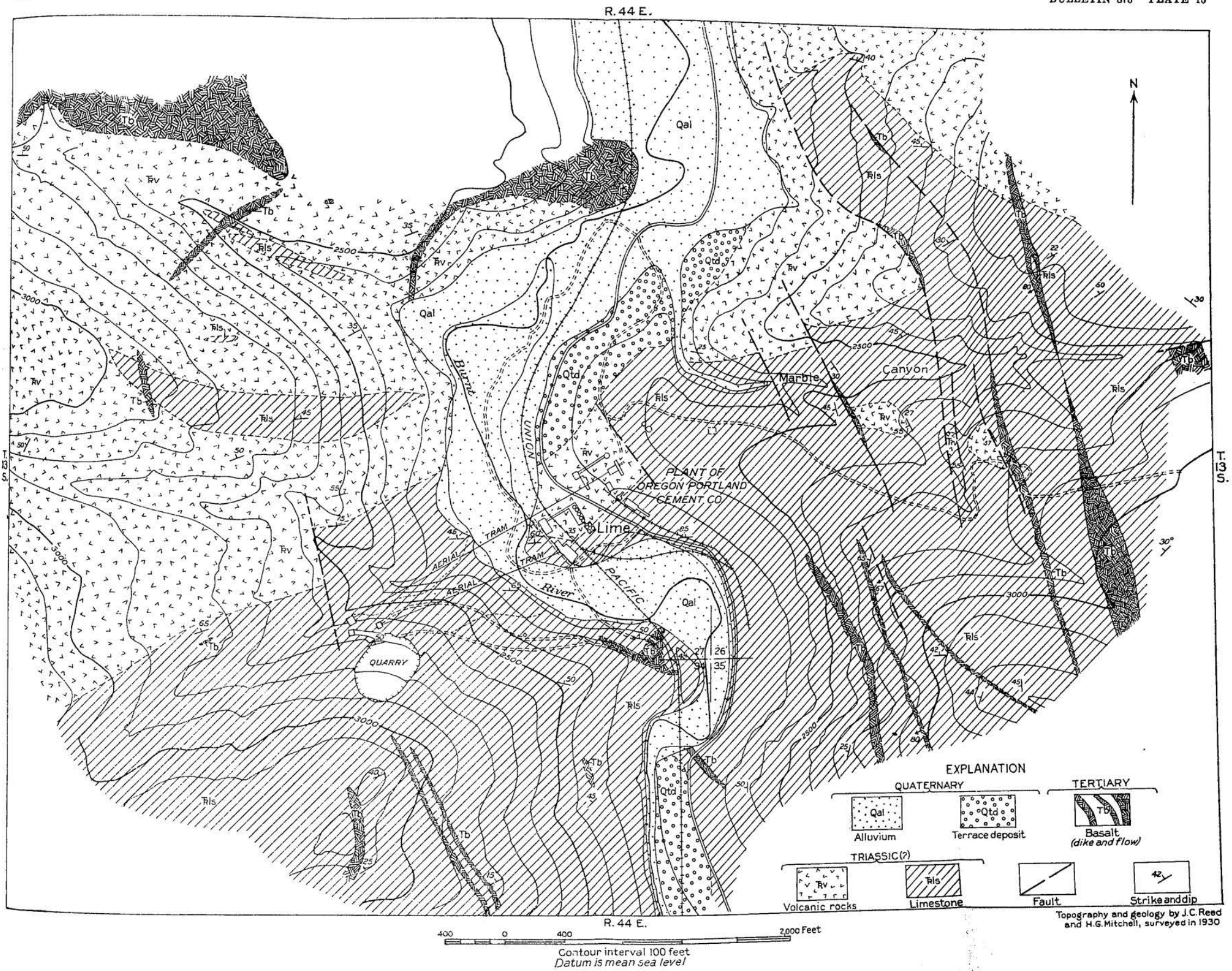

GEOLOGIC MAP OF LIMESTONE DEPOSIT AT LIME, BAKER COUNTY. 
in aerial tramcars 2,000 feet to the mill by gravity. The quarry operates 6 days a week and supplies 300 tons of limestone a day, which is sufficient to keep the mill in continuous operation. The quarry costs are said to be low. The necessary alumina and silica are obtained from a "clay", an altered Miocene volcanic tuff, which is quarried at Durkee. Two carloads of this material a day are needed to keep the mill in continuous operation. The water necessary to run the mill is obtained from the Burnt River. Utah coal is used, and also gypsum from Nephi, Utah.

\section{CROOK AND GRANT COUNTIES}

In the high part of the Ochoco Mountains, south of Canyon City, in Grant County, and in the headwaters of the Crooked River drainage system in Crook and Grant Counties, is a large area of Paleozoic and Mesozoic rocks which contains extensive deposits of limestones. E. L. Packard ${ }^{63}$ of the University of Oregon, and R. L. Lupher, ${ }^{64}$ of Washington State College, are studying the formations of this region. Dr. Lupher extended many courtesies to R. W. Richards and me during our brief visit to this district in 1930 .

The limestone in this region occurs in two formations, one Mississippian and the other Jurassic. The Mississippian beds crop out near Supplee, in Crook County. Of these Packard says : ${ }^{65}$

Paleozoic limestones have been found at several localities along the South Fork of John Day [River], upper Beaver Creek, and especially along Grindstone and Twelvemile Creeks, both tributaries of -Crooked River. The most extensive section now known is obtainable across a well-defined Paleozoic anticline trending southwestward from near Supplee and extending for a distance of at least 5 miles. This structure is composed of massive limestone and chert breccias, fine-grained gray fossiliferous limestones, extensive deposits of varicolored cherts, and thin-bedded light-colored limestones. Although this section has not been measured, it can scarcely be less than 3,000 feet in thickness.

The limestones of the Supplee anticline have yielded a fauna which Schuchert identified as the Baird Mississippian of California. Numerous specimens of Productus near giganteus Martin, measuring 8 to 10 inches in length have been collected, associated with Productus near striatus Fisher and Spirifer striatus Martin, as well as undetermined species of brachiopods, corals, bryozoans, and mollusks. The faunas of other Paleozoic areas have not as yet been studied, but they are presumed to include upper Paleozoic horizons.

The Mesozoic rests with marked structural unconformity upon the Paleozoic limestones. The Triassic, Jurassic, and Cretaceous systems are each separated by marked evidences of orogenic movements, which if added to those undoubtedly recorded in the Tertiary formations will make a long list of mountainmaking epochs for central Oregon.

\footnotetext{
${ }^{\text {es }}$ Packard, E. L., A new section of Paleozoic and Mesozoic rocks in central Oregon : Am. Jour. Sci., 5th ser., vol. 15, pp. 221-224, March 1928.

${ }^{64}$ Lupher, R. L., Geological section of Ochoco Range and Silvies Plateau [abstract] : Pan-Am. Geologist, vol. 54, no. 2, p. 158, September 1930.

${ }^{*}$ Packard, E. L., op. eit., p. 222.
} 
The oldest of these formations are typically exposed at the mouth of Freeman Creek near the headwaters of Beaver Creek, extending principally eastward into the basin of South Fork of John Day and even as far as Bear Valley. These beds consist of extensive bodies of dark fine-grained shales, considerable thicknesses of indurated sandstones, and grits and heavy conglomerates, often derived, largely from the underlying Paleozoic limestones but also containing metamorphic rocks from some unknown terrain. These have been closely folded, and the structures usually cross those of the underlying Paleozoic. Although this extensive system has not been studied, a characteristic Triassic brachiopod fauna has been obtained.

A series of shales, masses of impure limestone, and sandstones, and conglomerates containing a rich and varied Jurassic fauna overlie these Triassic beds with marked unconformity in places, probably representing the complete removal of the Triassic. Mr. Ralph Lupher, who is making a special study of the Silvies River section, reports in the eastern portion of the field the presence of at least two Jurassic formations first found near Supplee, the lowermost containing the fauna of Pecten acutiplicatus of Gabb, indicative of the Hardgrave of California. This older fauna includes a highly specialized type of pachydont mollusk constituting the principal species of thick fossiliferous beds traceable for many miles across the field.

The Cretaceous system is represented by a thin section of sandstones and shales exposed along Beaver Creek near Supplee. These beds rest unconformably upon Paleozoic and possibly Jurassic rocks and are overlain by middle or late Tertiary sediments and tuffs.

The Paleozoic beds are best exposed in T. 18 S., R. 25 E. The surface of the country in this township is rolling and covered with grass and sagebrush, though in the higher parts an open pine forest is found. Though most of the region is soil-covered, there are several outcrops of the Paleozoic limestone from which collections were made. These collections were examined by G. H. Girty, who has furnished the following lists:

6879 (field no. 139 ), sec. 28 , T. 18 S., R. 25 E. :

Stenopora, n. sp.

Derbya? sp.

Productus aff. P. mammatus.

Productus aff. P. tartaricus.

Productus aff. P. inflatus Tschernyschew not McChesney.

Pustula aff. P. fasciata.

Pustula aff. P. tuberculata.

Pustula aff. P. curvirostris.

Pustula aff. P. pseudoculeata?

Pustula sp.

Camarophoria sp.

Camarotoechia? sp.

Dielasma n. sp.

Spirifer sp.

Spiriferina sp.

Spirifer aff. S. laminosus.

Squamularia sp. 
6867 (field no. 140), sec. 19, T. 18 S., R. 25 E.:

Diphyphyllum? n. sp.

Campophyllum n. sp.

Productus aff. P. gruenewaldti.

Productus aff. P. tartaricus.

Productus aff. P. tartaricus var.

Pustula aff. P. pustulata.

Aulosteges? n. sp.

Camarophoria sp.

Rhynchopora aff. R. nikitini.

Ambocoelia? sp.

According to Girty these faunas, though differing in facies and representing decidedly novel aspects, are both of Permian age. They are more closely related to the Permian fauna of Alaska than to any other.

A sample of limestone from locality 140 was submitted to the chemical laboratory of the Geological Survey, for analysis, with the following result:

Analysis of limestone from sec. 19, T. 18 S., R. $25 \mathrm{E}$.

[J. G. Fairchild, analyst]

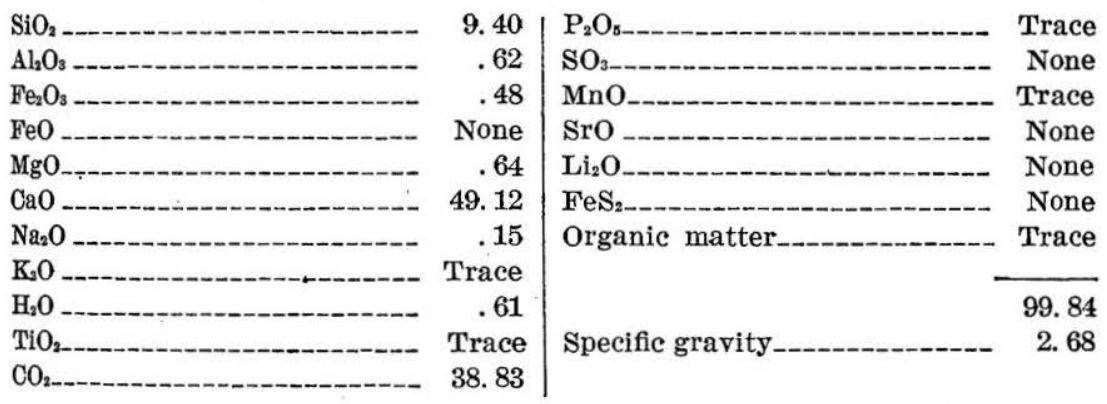

The silica $\left(\mathrm{SiO}_{2}\right)$ is high for use of this material in lime burning, but the limestone might be used for cement manufacture. The distance of the deposit from centers of consumption makes it of little value except for local purposes.

On Jackass Creek, in Grant County, in sec. 18, T. 17 S., R. 26 E., a bed of limestone about 15 feet thick is exposed. This bed is formed of Jurassic fossil shells and is found in all the areas of Jurassic rocks in this region. The limestone is light gray and, except for the larger shells, finely crystalline. A sample analyzed in the chemical laboratory of the Geological Survey yielded the following result: 
Analysis. of limestone from sec. 18, T. 17 S., R. 26 E.

[J. G. Fairchild, analyst]

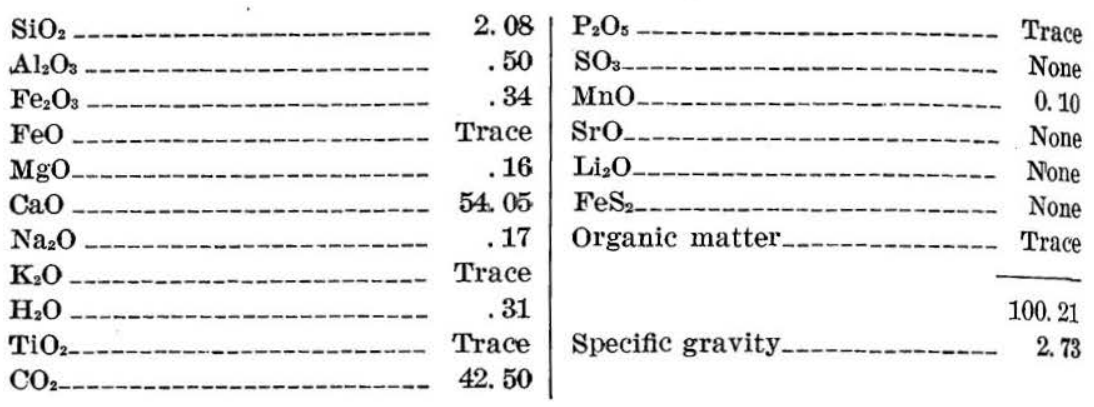

This analysis indicates a limestone of considerable purity that might well be used for a local source of quicklime and lime products. The bed, though thin and considerably folded and faulted, is extensive and capable of furnishing large quantities of material. Distance from centers of consumption and from railroads render it of questionable value. For domestic consumption and for supplying the towns of Burns, Prairie City, John Day, and Dayville it might possibly be worked intermittently on a small scale.

\section{WHEELER COUNTY}

Limestone deposits in Wheeler County, so far as known, are restricted to small lenticular bodies occurring in the areas of preCretaceous rocks on Shoofly Creek between Mitchell and Richmond and in the region between Antone and Dayville. These bodies are very small and, though capable of furnishing sufficient quantities of limestone for local use, are of no great economic importance. The deposits on Shoofly Creek have been used in the past for making quicklime for local consumption and have been described at some length by Collier. ${ }^{66}$ This locality was visited in the season of 1931.

\section{SHOOFLY CREEK}

Shoofly Creek rises in the northeastern part of T. 11 S., R. 22 E., and flows in a northerly direction to the John Day River, a distance of about 10 miles. The limestone deposits are near its head, on a small fork known as Limekiln Creek. At this point the stream flows in a very narrow and steep-walled canyon, the floor of which is about 3,500 feet in altitude, and the walls from 4,500 to 5,000 feet. The deposits are reached from the Mitchell-Service Creek road across Shoofly Creek by about 5 miles of poor farm and woods roads.

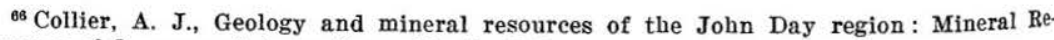
sources of Oregon, vol. 1, no. 3, pp. 39-41, 1914.
} 
The limestone forms lenses in a series of old sandstones and pebble conglomerates, now metamorphosed to quartzites. These sediments have been intruded by later basic lava dikes, which have been metamorphosed to greenstones and serpentines. All the old rocks have then been intruded by basic dikes, feeders of the Tertiary lavas.

The largest lens of limestone is in the northeast corner of the $\mathrm{SE} 1 / 4 \mathrm{SE} 1 / 4$ sec. 1 , T. 11 S., R. 22 E. It is about 20 feet thick and extends about 150 feet down the slope. It strikes N. $75^{\circ} \mathrm{W}$. and dips almost $90^{\circ}$. Several smaller lenses appear in the walls of the canyon to the south. This lens is composed of limestone with small amounts of interbedded quartzite and is entirely surrounded by greenstones. The contact with the greenstones is marked by a serpentinized zone from a few inches to several feet thick.

The limestone is a fine-grained dark-gray rock which weathers to light gray on outcrops. In places it is seamed with white calcite veins. Much of it is silicified, and the irregular pattern formed by the black cherty material with the fine-grained limestone and the more crystalline material makes quarrying of pure rock rather difficult. No analysis has been made of the limestone, but inspection shows that as a whole it is rather impure.

The small size and inaccessible location of this deposit render it of no practical value. The impurity of most of the limestone and the expense of selecting and burning the higher-grade material prohibit development except in a small way for local use.

\section{LUMP PUMICE}

Lump pumice is a fragmental volcanic rock formed of a highly cellular glass. It is very light in weight, light colored, and porous. In the eruption of viscous types of lava containing water vapor and gases the relief of pressure causes the formation of a froth which solidifies and breaks and is expelled from the volcano as pumice and volcanic ash or dust. The correct conditions for the formation of pumice are met in the more siliceous lavas, such as rhyolites and dacites, but the highest grades of pumice are seldom found. Associated with lump pumice is usually a certain amount of volcanic dust and also the incompletely expanded glassy lava or obsidian.

The main use of lump pumice is as an abrasive. In the lump form it is used to smooth lithographic stones, to clean metal surfaces for electroplating and painting, and to rub down painted and varnished surfaces. The greater part of the lump material is ground to powder, and relatively little is used as an abrasive in the lump form. A high-grade lump pumice must consist of sufficiently large lumps to trim to hand-size blocks. It must have a very uniform texture and contain no stony or glassy blebs. As the abrasive action of 
pumice depends on the cutting action of the thin glass walls it is imperative that no hard grains be present which would gouge or scratch the surface being polished. For different classes of work the quality required varies. Besides abrasive uses, lump pumice is used as a light-weight aggregate for concrete, to some extent as an insulant, as an absorptive packing, and as an ingredient in acoustic stuccos for sound deadening. The material may be ground and used as an admixture for concrete, increasing the workability, the strength, and the resistance to corrosive waters.

\section{PRODUCTION}

Small quantities of lump pumice are produced in California and Arizona, but by far the greater amount used in the United States is imported from Italy. The Italian deposits on the island of Lipari are the most developed in the world.

\section{BEND-KLAMATH FALLS REGION}

\section{LOCATION}

Lump-pumice deposits are abundant in the southwestern part of eastern Oregon, in the region east of Crater Lake between the towns of Bend and Klamath Falls. These deposits occupy the southern part of Deschutes County, the northern part of Klamath County, and the northwest corner of Lake County, an area of over 3,500 square miles. Though the principal part of these deposits is made up of fine lumps and granules, there are great quantities of large lump material and smaller amounts of pumice which should yield lumps comparable to the best Italian grades.

\section{INVESTIGATION}

These deposits were noted during the reconnaissance of 1930 . No published information concerning them was found except brief notes by Diller ${ }^{67}$ and Russell, ${ }^{68}$ which did not discuss their thickness or extent.

In 1931 I' spent about 6 weeks in a reconnaissance study of the deposits. The entire region was traversed as thoroughly as possible by automobile, and extensive collections of the pumice were made. Topographic maps were not available for most of the area, and time was not sufficient to make a geologic map of this region, which is largely forested. More detailed work will be necessary before exploitation of the deposits can be intelligently carried out.

or Diller, J. S., and Patton, H. B., The geology and petrography of Crater Lake National Park : U. S. Geol. Survey Prof. Paper 3, pp. 39-41, 1902.

${ }^{68}$ Russell, I. C., Preliminary report on the geology and ground-water resources of central Oregon: U. S. Geol. Survey Water-Supply Paper 252, pp. 131-133, 1935. 
The pumice deposits are situated in the northwesternmost part of the Basin Ranges of eastern Oregon. The general altitude of the flat country is between 4,000 and 4,500 feet. The higher country consists of several topographic types and may be divided into the Cascade Range, which forms a ragged rim along the western margin of the broken plateau; faulted block mountains, such as Walker Rim and the mountains of the Klamath Lake region; and volcanic mountains built up on the old plateau surface, such as the Paulina Mountains and Yamsay Mountain.

The Cascade Range consists of a chain of volcanic cones, built up in Pliocene and Pleistocene time, which have been glaciated. The original volcanic aspect of some of these cones, notably Mount Thielsen, has been greatly altered by the action of the ice. At the present time Mount Thielsen forms a rugged pinnacle of rock, a typical horn. In the building up of the Cascade Range volcanoes were spaced so far apart that the passes over the range were not deeply filled with lava. Many of the passes are but a few hundred feet higher than the region to the east.

The region to the east of the Cascade Range may best be considered a plateau which has been broken by faulting and upon which many volcanoes have been built. In the region around Bend, where faults are not conspicuous, multitudes of cinder cones of heights ranging from a few hundred feet to more than 1,000 feet may be found, some so well preserved that they appear of recent date. These cones, which belong to the same general period of volcanism as those of the Cascade Range, are associated with numerous flows of volcanic rocks. Among the largest of these old volcanoes are the Paulina Mountains and Yamsay Mountain. The Paulina Mountains, which are visible as a group of ragged peaks east of the DallesCalifornia Highway, in Tps. 21 and 22 S., Rs. 12 and 13 E., are the remnants of an old crater, which was named "Newberry Crater" by Russell. ${ }^{69}$ The highest point is nearly 8,000 feet above sea level, on the south rim. The interior of the old crater, though not as large as that of Crater Lake, was about 5 miles in diameter. It is now filled by a series of small cones, and by two depressions, one on each side, occupied by Paulina Lake and East Lake. Yamsay Mountain is about 36 miles due east of Crater Lake and 54 miles south of the Paulina Mountains. It is a large conical mountain, 8,200 feet in altitude. The volcanic nature of this peak is shown by the dip of the lavas away from its center. The original crater, which was very small, has been breached by glacial action, and a steep $\mathrm{U}$-shaped gorge drains to the north. There are other volcanic peaks too nu-

\footnotetext{
${ }^{\infty}$ Russell, I. C., op. cit. (Water-Supply Paper 252), p. 97.
} 
merous to mention. They are all of importance in the explanation of the peculiar type of topography existing in this region. The apparent indiscriminate distribution of volcanic cones and lava flows has given rise to a topography over which the streams have no control. Damming of the streams by the growth of these features has led to the development of lakes and meadows. Both the major and the minor topographic features of the region have been affected. Lava flows still preserve their surface features, such as pressure ridges (ridges of lava formed by the buckling of the crust of the flows while the interior mass was molten). These ridges, generally from 10 to 15 feet high, open at the top and of variable length, are common features and occur in the forests as well as in the open country. Lava tunnels are numerous. The visitor can gain access to them through openings produced by the caving of their roofs. In some of these tunnels the poor circulation of air and the excellent insulating properties of the lava preserve ice the year around. Many of the roads make abrupt turns to avoid lava flows which present to the traveler their unaltered fronts from 25 to 100 feet high. The surfaces of these flows are so ragged that travel across them by vehicle is impossible except on areas covered with pumice or soil.

In the central and southern parts of this region the topography is complicated by the presence of block-faulted hills and mountains. One of the northernmost of these is the Walker Rim, a crescentshaped fault scarp which attains its full height in Walker Mountain, at the westernmost point, at an altitude of 7,000 feet. The region east of the rim is flat and but little dissected. It sinks gradually to the level of the rest of the region to the north and south. On the back slope is Sellers Marsh, now dry, the relic of an old lake. The slope is drained to the south by Jack Creek, at the head of which numerous flats, representative of former marshes and lakes, occur in abundance. Small cones such as Skookum Butte are built up on this surface, but whether they are younger or older than the faulting is not known. To the south easily recognized fault blocks are numerous. South of Klamath Marsh the topography is dominated by a series of ridges from 500 to 1,000 feet high which strike in a general direction of north-northwest. Faults are particularly prominent in the region to the south of the lump-pumice region around the Klamath Lakes, and probably equally striking fault topography is present in much of this region but is not visible to the traveler because of the thick forest cover.

\section{DRAINAGE}

The drainage of this region is effected by three systems-the Deschutes River and its tributaries to the Columbia River and the Pacific Ocean; smaller streams on the eastern boundary into Silver 
Łake and Fort Rock Basin; and the Williamson and Wood Rivers and their tributaries to the Klamath River and the Pacific. In this region flowing streams are rare and generally large. The soil is composed chiefly of extremely porous granular pumice, underlain by considerable thicknesses of relatively young lavas, which are also porous because of their numerous joints and vesicular texture. Streamlets are therefore strikingly absent in the pumice and lava areas, and except during very heavy rains all precipitation sinks into the ground and circulates below the surface.

\section{GEOLOGY}

The oldest rocks in this region are volcanic rocks of late Tertiary and Quaternary ages, which form the present Cascade Range. In a general way they form a great confused mass of interlacing lava flows and volcanic cones which have been blanketed by several sheets of pumice. Along the crest of the range volcanic cones are numerous, but to the east most of the rocks are flows.

\section{PRE-PUMICE ROCKS}

Occurrence.-An interesting section of the lower portion of the series of lavas may be seen in the vicinity of the Klamath Lakes. It is summarized in the table given in the description of the Klamath diatomite district (p. 36).

Though these rocks lie south of the pumice district, they are of interest because they form the lowest part of the lava series in this region and because their relation to the formations regarded as corresponding to the Payette formation probably limits their age to Pliocene or possibly Pleistocene.

An interesting section of the pre-pumice lavas is found at Crater Lake and has been described in detail by Diller and Patton. ${ }^{70}$ This lake is included in one of the national parks and is well known to the public. The history of old Mount Mazama, the volcano whose partial destruction gave rise to the present crater, has been told too often to be repeated here. According to Diller there are three types of lavas in this region-andesites, dacites, and basalts. The great bulk of Mount Mazama was formed of hypersthene andesite, of which many flows can be counted in the present crater walls. These flows, usually formed of light-gray to green sheeted rocks, are from 30 to 80. feet thick and are commonly associated with a certain amount of pyroclastic material. According to Diller the lower members of the series are associated with greater thicknesses of agglomerates than the upper member. Later than the andesites are olivine basalts which, however, did not issue from Mount Mazama, ${ }^{70 \mathrm{a}}$ but form small

\footnotetext{
${ }^{70}$ Diller, J. S., and Patton, H. B., op. cit. (Prof. Paper 3), pp. 23-41.

${ }^{10 a}$ For a recent discussion of Mount Mazama see Smith, W. D., and Swartzlow, C. R., Mount Mazama : Explosion versus collapse: Geol. Soc. America Bull., vol. 47, pp. 18091930, Dec. 31, 1936.
}

$63952-37-11$ 
cones around its base and on its sides. Associated with these lavas are the dacite flows and pyroclastic rocks. Although the last activity of the old volcano was a great eruption of dacite pyroclastic material, the early dacite flows may have been in part contemporaneous with the basalts. ${ }^{71}$ The dacites are highly diverse in character, ranging from glassy rocks such as obsidian to fine-grained porphyritic rocks. These dacites record some of the latest chapters of the history of this region, for the great pumice sheet that covers so much of the area north-east of Crater Lake represents an eruption of dacite pumice from a crater of Mount Mazama.

Other sections in this region might well be studied. In my brief reconnaissance, however, little time was available for detailed examination of the rocks in the few places where the pumice soil cover was absent. The Paulina Mountains, which were hastily examined in this reconnaissance, have since been studied by Williams, ${ }^{72}$ who has described them in detail with the exception of the pumice.

The flat regions in this district are underlain by a thick series of lava flows. Walker Mountain and Walker Rim are formed of a thick series of flows composed largely of a platy gray porphyritic andesite. The flows to the east, along the margin of the deposit, appear to be largely olivine basalts. An open-textured silver-gray basalt with conspicuous olivine phenocrysts is the ordinary type observed. Striking examples of these basalt flows can be seen along the Fremont Highway on the western edge of the Fort Rock Basin, where they lie unconformably over bright-colored tuffs and pumiceous rhyolite flows of probable Payette age.

Age.-The age assigned to the pre-pumice lavas in the Cascade Range is unfortunately not based on fossil evidence obtainable in this particular region. However, a consideration of the age of what appears to be this same series of lavas at other places points to a late Tertiary and Quaternary age.

The relations of the rocks forming the Cascade Range are best seen in the Columbia River Gorge. The oldest rocks exposed are andesitic pyroclastic rocks of Oligocene or lower Miocene age. From these a flora has been obtained which Chaney ${ }^{73}$ has described under the name Eagle Creek flora. Overlying these pyroclastic rocks is about 2,000 feet of the Columbia River lava. The number of flows is about 20 , and the entire series, with the exception of very thin scoriaceous crusts and some thin layers of old soil, is solid flow rock. The Dalles formation, of Miocene or Pliocene age, rests upon the Columbia River lava with apparently conformable relations.

\footnotetext{
${ }^{\tau_{1}}$ Diller, J. S., and Patton, H. B., op. cit., p. 23.

72 Williams, HI.. Newberry Volcano of central Oregon: Geol. Soc. America Bull., vol. 46, pp. 253-304, 1935.

${ }^{73}$ Chaney, R. W., Ecologic significance of the Eagle Creek flora of the Columbia River Gorge: Jour. Geology, vol. 26, pp. 577-598, 1918.
} 
This whole series of rocks lies in a series of three folds striking about N. $60^{\circ} \mathrm{E}$., which have been beveled. On these folds the present Cascade Range has been built up of andesitic and basaltic lava flows, which, to judge from the age of the older formations, can be no older than Pliocene.

The relations of the Pliocene lavas of the Cascade Range can also be seen farther south, in the middle Deschutes drainage basin. In the vicinity of Madras, about 50 miles north of Bend, there is a large area of early Tertiary and Cretaceous formations, lying in folds that form the western continuation of those of the Ochoco Mountains. These formations cross the Deschutes River and are covered to the west by the undeformed lavas of the Cascade Range. They include Cretaceous marine sediments, the Clarno formation (Eocene), the John Day formation (Oligocene and lower Miocene), and the Columbia River lava (Miocene). The relation of these folds to the overlying lavas of the Cascade Range is the same as that of the folds in the Columbia River Gorge, just described, and from a consideration of their lithology a similar age may be assigned to the overlying lavas.

In the Klamath Falls region and the Fort Rock Basin the flows of the lava series of the Cascade Range rest on what are believed to be representatives of the Payette formation. No fossils have yet been obtained from these rocks, but their lithologic similarity to Payette rocks to the east suggests the correlation. The lava of the Klamath Falls region contains interbedded diatomite, which has a flora so strikingly different from that of the Payette formation that no hesitation is felt in stating that it is of different age.

On the basis of these facts the age of the lavas forming the present Cascade Range is believed to be Pliocene and younger. Diller's statement that "during the Miocene the volcanoes of the Cascade Range were most active and the greater portion of the range was built up" $7_{4}$ was made before sufficient work had been done to date the formations of eastern Oregon, and so was the statement by Russell that "these volcanoes may be safely concluded to range in geologic age from the earlier portion of the Tertiary period to recent centuries." is Though a late Tertiary and Quaternary age may appear to be extremely recent for this range, the geology of the Columbia River Gorge shows that in that part of the range this assignment is correct, and the evidence available at other localities strengthens rather than weakens this view.

\section{PUMICE}

A great blanket of pumice covers the northern part of Klamath County and the southern part of Deschutes County with the excep-

\footnotetext{
${ }^{7}$ Diller, J. S., and Patton, H. B., op. cit. (Prof. Paper 3), p. 20.

${ }^{7 \pi}$ Russell, I. C., op. cit. (Water-Supply Paper 252), p. 95.
} 
tion of some of the steeper hills and slopes. Its thickness is fairly uniform, except where it has drifted. Both Diller ${ }^{76}$ and Russell ${ }^{n}$ have given brief descriptions of this blanket. In the reconnaissance of 1931 it was found to be composed not of one sheet of pumice but of four sheets, of which the two most extensive had their origin in the .old crater occupied by Crater Lake; the third in the crater of old Mount Newberry, and the smallest in the eruption of Devils Hill. The size and location of these different sheets are shown in plate 16 . The largest and most conspicuous of these pumice sheets is the later one of Crater Lake.

\section{PUMICE OF CRATER LAKE}

The older of the two sheets originating in the crater now occupied by Crater Lake is composed of lump pumice ranging from blocks several feet in diameter to the finest volcanic ash or dust. The younger and more extensive sheet is made up of granular pumice, clean and well sorted, which covers the main part of the pumice area and may be traced as a light pumiceous soil far beyond the limits shown on the map.

Older pumice.-The older pumice of Crater Lake forms an irregular-shaped area which nearly encircles the lake. Its absence from the upper slopes of the crater and from the high mountainous country to the south is believed to be due both to subsequent erosion and to conditions of deposition. In the area shown by the map the pumice does not form a continuous blanket but occurs on the gentler slopes and on the flats and valleys between the nearby mountains. Along the Rogue River to the west of the summit of the Cascade Range there are numerous stream terraces cut in pumice-remnants of this same sheet, which filled the Rogue River Valley and covered the region to the east.

The thickness of the pumice is highly variable. In the terraces along the Rogue River it is as much as 60 feet. On the road to Diamond Lake just west of the summit of the Cascade Range more than 100 feet is exposed. No measurements of thickness were made, but east of Crater Lake the sheet gradually thins in the direction of Klamath Marsh. Klamath Marsh contains no pumice except near its shores, and in the country to the east no trace of the old pumice is to be found. Though the deposit is in general thin to the east of Crater Lake, many places may be found where there appears to be a considerable thickness. Near Lonroth, a station on the Southern Pacific Railroad, coarse pumice with lumps as much as 3 feet in diameter is exposed in a railroad cut some 10 feet deep. The thickness at different points is thought to vary not only according to erosion, which has removed different amounts of surface material,

${ }^{76}$ Diller, J. S., and Patton, H. B., op. cit., p. 40.

ๆ Russell, I. C., op. cit., p. 132. 
but also according to the irregularities of the old land surface on which it was laid down.

There is no recognizable sorting in any of the samples taken, and a still more striking fact is the lack of variation in coarseness of material with increased distance from the crater. Material obtained in the northeast corner of the sheet, near Lonroth station, is as coarse as that near the crater.

The large lumps of pumice are light gray but on weathering assume first a pink and then a yellow color. The finer material is pink and on fresh damp surfaces appears to be brick-red. Outcrops. are few, and exposures showing distribution of sizes are limited to. road and railroad cuts. Stream banks and hillsides in the region are covered with the larger weathered lump pumice; the finer material has been carried away by the wind. The pumice weathers: so rapidly that no great amount of concentration takes place.

The pumice itself is composed mainly of glass, which is finely resicular or even fibrous. A small percentage of phenocrysts of feldspar, hornblende, hypersthene, and magnetite is present. Vesicles, which range from about 0.1 inch to more than 3 inches in diameter, form 10 to 50 percent of the volume of the pumice. The walls of these vesicles resemble nests with fibrous coiled structures. of fine glass filaments from which a few crystals protrude. The alteration of the vesicles and the drifting of soil into them cause the exterior of many of these lumps to have a thin shell or rind that is less porous than the material inside.

The finer particles are formed of fragments of glass and small amounts of mineral grains. This material as studied with the naked eye is very uniform. Under the microscope the finer material appears to be mainly glass with a few grains of plagioclase feldspar (oligoclase to andesine), together with hypersthene, hornblende, augite, and magnetite. Some of the glass grains have smooth surfaces, the result of conchoidal fracture; others are formed of fragments of fine filaments which preserve on several sides the fine ridges or striae so desirable in grinding powders.

An analysis of a sample of the lump pumice has been made by the chemical laboratory of the Geological Survey, with the following result:

Analysis of lump pumice from sec. 17, T. 28 S., R. $8 \mathrm{E}$.

[J. J. Fahey, analyst]

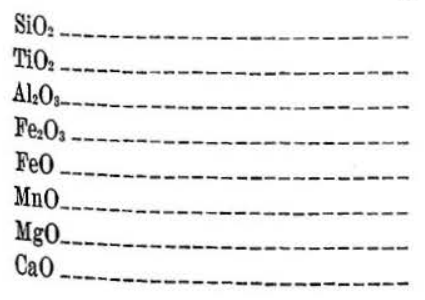

69.50

.41

15. 18

1. 24

1. 42

.03

.83

2. 08
4. 78

2. 18

.21

$\begin{array}{lr}\mathrm{CO}_{2} & \text { None } \\ \mathrm{H}_{2} \mathrm{O}_{2} & 2.51\end{array}$

100. 37 
Younger pumice.-An extensive sheet of granular pumice covers the greater part of Klamath County, the southern part of Deschutes County, and the northwest corner of Lake County. Only the part that lies east of the Cascade Range has been examined, though there are large areas to the west. The areal extent of material coarse. enough to be mapped as granular pumice as distinct from pumiceous soil is shown on plate 16. Though in this area there are later basaltic flows and cones, particularly in the northernmost part, and areas on the steeper hillsides from which the pumice has been removed by. the wind, the sheet as a whole covers the region effectively with a uniform layer of granular pumice which is 6 feet thick at the contacts with the older pumice and about 1 foot thick along the boundary as mapped. In several places, particularly along the southern shores. of Klamath Marsh and in the vicinity of Chemult, there are drifts of granular pumice as much as 40 feet thick. Granular pumice was. found on the west side of Yamsay Mountain extending within a few hundred feet of the top. The sides of many buttes in the region are covered by the pumice, only the summits showing continuous rock outcrops. In the flatter stretches of country the sheet is interrupted by projecting lava-pressure ridges that were too steep for the accumulation of the pumice.

The pumice composing this sheet ranges in texture from fine to coarse but may be recognized everywhere in this region by its light color, its sorting, and its peculiar-shaped particles. Over the entire region it is uniform in character except that the particles become uniformly finer toward the edge of the sheet.

The pumice is white where fresh, but weathering, which has affected the greater part of the sheet, turns it light yellow. In places where there is considerable moisture and vegetation it may be orangecolored or even rusty. Outcrops are few, the surface of the sheet being covered by a thin pumiceous soil formed of the upper weathered and disintegrated material. This soil is usually but a few inches and rarely over a foot thick. On the surface the larger lumps are concentrated by the removal of the finer particles, but weathering is so rapid that little coarse material accumulates.

The granular pumice is composed of two separate fractions-lumps of true pumice and mineral grains. The pumice is a porphyritic glass which is highly vesicular and very light. The phenocrysts in general amount to less than 5 percent of the volume of the pumice and are composed of glassy feldspar crystals and rod-shaped crystals of hornblende, hypersthene, and augite. These crystals are rarely more than 2 millimeters in length and more commonly. from 0.5 to 1 millimeter. The shape of the individual grains of pumice is very irregular. Though they are roughly round, the walls. of the broken vesicles protrude and produce a very irregular surface. 
The mineral grains range in size from 0.125 to 2 millimeters, but the greater percentage by weight is in the 0.5 - to 1 -millimeter fractions. The feldspars are plagioclase and range in composition from oligoclase to acid labradorite. Magnetite is rare as separate crystals but abundant as inclusions in the other crystals. Small amounts of glass are present, but it is believed that all the fines composed of glass in this material came by weathering from the larger pumice lumps. The following analysis of the lump pumice from a locality near Chemult was made in the laboratory of the Geological Survey:

Analysis of lump pumice from sec. 8, T. 27 S., R. \& E.

\section{[J. J. Fahey, analyst]}

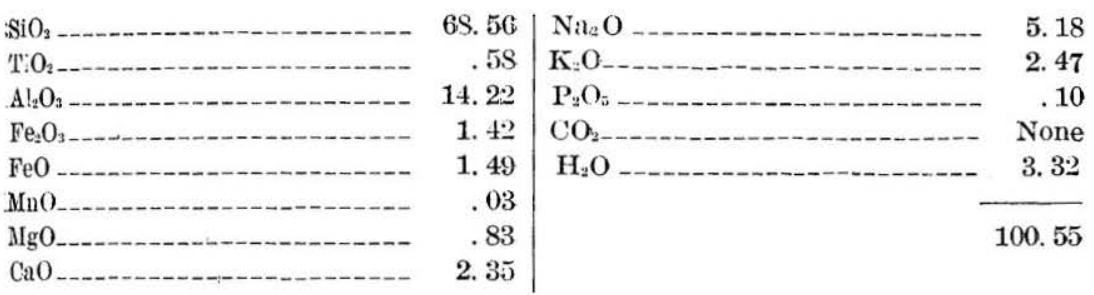

Relations of the pumice sheets.-In the region south of Chemult the contact between the younger and older pumices of Crater Lake can be studied over long distances. The granular pumice lies above the more rudely sorted material and is therefore clearly younger. Because of the looseness and coarseness of particles in the two pumices it is impossible to tell whether the contact is erosional or not. "The similarity in chemical composition suggests that they were erupted from the same body of liquid rock and are consequently of nearly the same age. The fact that both are weathered to the same extent also suggests conformity.

No traces of the older pumice have been found north of the contact shown except in a few localities near Chemult. In the quarry southeast of Chemult (localities 150-156, pl. 16) the granular pumice rests upon a coarse red volcanic ash believed to represent the older pumice, and a similar ash occurs in the bottom of the railroad cut east of locality 1. At other localities within a few miles of the contact the older pumice is absent and the younger pumice rests directly upon lavas or alluvium. The absence of the older pumice at all other localities studied suggests that it was deposited only over essentially the area it now covers.

The area mapped as granular pumice on plate 16 represents the extent of recognizable occurrences of this material. Beyond its borders pumiceous soil is found for many miles to the east, and in the northeastern part of the State, in Wallowa and Baker Counties, beds of white volcanic ash that possibly represent the finer portions 
of this sheet may be found in sheltered valleys. In the région imme. diately surrounding Crater Lake the sheet has been removed by erosion.

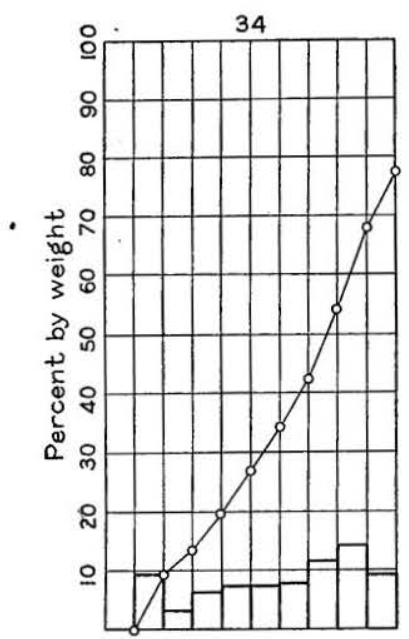

E⿻心 E⿻

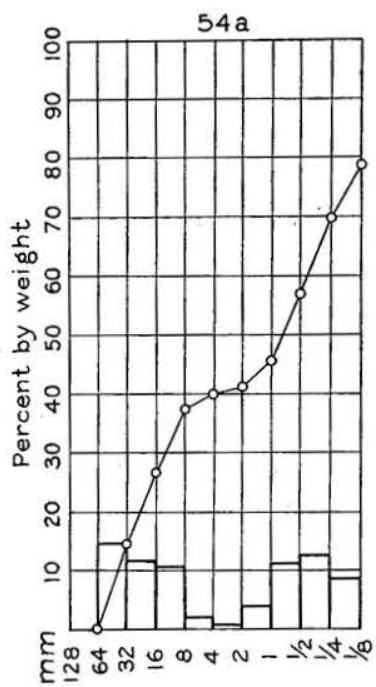

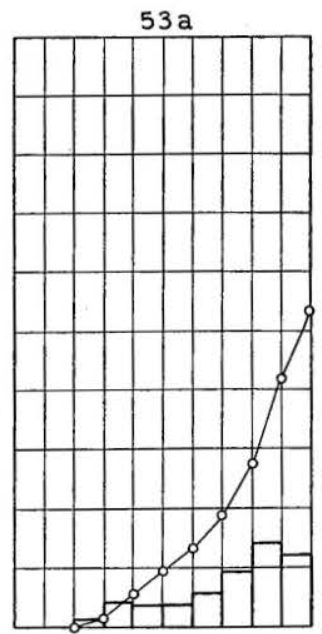

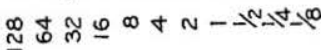

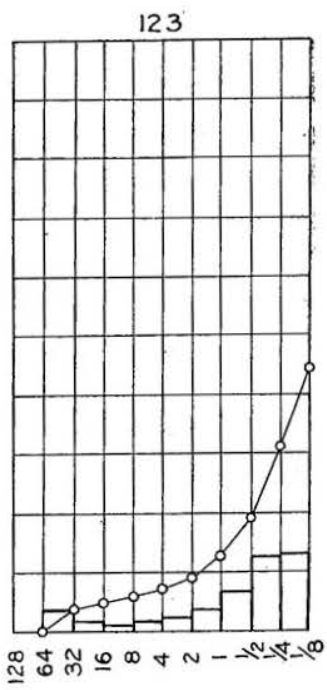

Figure 8.- Size distribution of finer parts of older pumice of Crater Lake.

Origin.-Although the two types of pumice are very similar in chemical and mineral composition there is a distinct textural difference, which points to different modes of origin. The following tables present the results of mechanical or screen analyses made of samples collected in 1931 . 
Mechanical analyses of finer portions of older pumice of Crater Lake

\begin{tabular}{|c|c|c|c|c|c|c|c|c|c|c|c|c|}
\hline $\begin{array}{l}\text { No. on } \\
\text { pl. } 16\end{array}$ & Locality & $\begin{array}{c}64-32 \\
\text { milli- } \\
\text { meters }\end{array}$ & $\begin{array}{l}32-16 \\
\text { milli- } \\
\text { meters }\end{array}$ & $\begin{array}{c}\text { 16-8 } \\
\text { milli- } \\
\text { meters }\end{array}$ & $\begin{array}{c}8-4 \text { milli- } \\
\text { meters }\end{array}$ & $\begin{array}{c}4-2 \text { milli- } \\
\text { meters }\end{array}$ & $\begin{array}{l}2-1 \text { milli- } \\
\text { meters }\end{array}$ & $\begin{array}{l}1-0.5 \\
\text { milli- } \\
\text { meter }\end{array}$ & $\begin{array}{c}0.5-0.25 \\
\text { nilli- } \\
\text { meter }\end{array}$ & $\begin{array}{l}0.25- \\
0.125 \\
\text { milli- } \\
\text { meter }\end{array}$ & $\begin{array}{c}\text { Less than } \\
0.125 \\
\text { milli- } \\
\text { meter }\end{array}$ & Total \\
\hline 24 & Southwest corner of NE1/4SW1/4 sec. 23, T. 28 S., R. 7 E_- & 1.7 & 3.1 & 6.0 & 6.7 & 7.2 & 8.4 & 12.6 & 14.7 & 9.6 & 30.0 & 100.0 \\
\hline $\begin{array}{l}25 \\
33\end{array}$ & SW1/4SE1/4 sec. 35, T. $28 \mathrm{~S}$., R. $6 \mathrm{E}$ & 10.3 & 6.5 & 7.7 & 8.5 & 7.2 & 8. 7 & 11.8 & 13. 1 & 7.8 & 18. 4 & 100.0 \\
\hline $\begin{array}{l}33 \\
34\end{array}$ & SW1/4SE1/4 sec. 2, T. 29 S., R. $5 \mathrm{E}$ (unsurveyed) & 16.3 & $\begin{array}{r}13.6 \\
3\end{array}$ & & 6.8 & 5.7 & 6.8 & 11.5 & 15.1 & 8.7 & 8.1 & 100.0 \\
\hline $\begin{array}{ll}34 \\
41\end{array}$ & & $\begin{array}{r}9.5 \\
7.2\end{array}$ & $\begin{array}{r}3.3 \\
7.7\end{array}$ & $\begin{array}{ll}6.3 \\
5.3\end{array}$ & 7.5 & $\begin{array}{l}7.5 \\
7.0\end{array}$ & 7.8 & 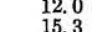 & $\begin{array}{l}14.0 \\
18.6\end{array}$ & 9.1 & 23.0 & 100.0 \\
\hline 42 & Northwest corner of SE1 $/ 4 \mathrm{SE} 1 / 4$ sec. 35 , T. $31 \mathrm{~S}$., R. $7 \mathrm{E}-$ & 7.5 & 3.0 & $\begin{array}{ll}3.0 \\
3.2\end{array}$ & $\begin{array}{ll}3.0 \\
3.3\end{array}$ & 4.0 & 7.0 & 17.6 & $\begin{array}{l}18.6 \\
25.5\end{array}$ & $\begin{array}{r}9.6 \\
12.5\end{array}$ & $\begin{array}{l}12.9 \\
16.4\end{array}$ & $\begin{array}{l}100.0 \\
100.0\end{array}$ \\
\hline 45 & Center of SW1 14 soc. 32 , T. 31 S., R. 7 E. & & 6 & 5. 9 & 5.8 & 6. 3 & 8.2 & 14. 3 & 20.5 & 11.6 & 21.8 & 100.0 \\
\hline 46 & South center of SE $1 / 4$ sec. 9 , T. 31 S., R. $7 \mathrm{E}$. & 3.8 & 7.4 & 8.8 & 7.7 & 6.0 & 7. 1 & 10.9 & 16.1 & 10.4 & 21.8 & 100.0 \\
\hline 47 & Southeast corner of sec. $27, T .30$ S., R. 7 E........... & 16.9 & 3.7 & 3. 0 & 3.4 & 4.7 & 6.4 & 12.5 & 18. 3 & 11.8 & 19. 3 & 100.0 \\
\hline 48 & Extreme south center of NE $1 / 4$ sec. 14, T. $30 \mathrm{~S}$, R. 7 E.- & 4.3 & 11.5 & 8.4 & 5. 9 & 5.8 & 7.8 & 13.4 & 15.7 & 8.5 & 18.7 & 100.0 \\
\hline $53 \mathrm{a}$ & South center of NW1/4 sec. 17, T. 28 S., R. 8 E........... & & 1.4 & 4.0 & 3.8 & 3.8 & 5.4 & 9.2 & 14. 0 & 12.0 & 46.4 & 100.0 \\
\hline $54 \mathrm{a}$ & Northeast sorner of sec. 1, T. 29 S., R 7 E.......... & 14.8 & 12.0 & 10.7 & 2.3 & 1.0 & 4.5 & 11.6 & 12.9 & 8.4 & 21.8 & 100.0 \\
\hline 55 & North center of SE $1 / 4 \mathrm{Sec} 31$, T. 32 S., R. 8 E & & 1.1 & 6.0 & 6.5 & 6.3 & 7.0 & 10.5 & 12.7 & 12.4 & 37.5 & 100.0 \\
\hline 61 & Southwest corner of NW $1 / 4$ sec. 12 , T. 30 S., R. 8 E. & & 4.3 & 6.1 & 6.1 & 5.7 & 6.9 & 10.3 & 14.0 & 12.0 & 34.6 & 100.0 \\
\hline 64 & North center of NE $1 / 4 \mathrm{SE} 1 / 4$ sec. 28 , T. 29 S., R. 8 E... & 5.7 & 3.6 & 5.3 & 4. 9 & 4.9 & 6.7 & 8. 2 & 11.0 & 13.5 & 36.2 & 100.0 \\
\hline $\begin{array}{l}66 \\
77\end{array}$ & $\begin{array}{l}\text { Southeast corner of NW1/4 sec. 5, T. } 29 \text { S., R. } 8 \text { E. } \\
\text { Northeast corner of SW14SW1/4 sec. } 24, \text { T. } 29 \text { S., R. } 61 / 2\end{array}$ & 5.0 & 1 & 3 & 3.7 & & 5. & 10.4 & 16. & 16.9 & 34.1 & 100.0 \\
\hline & E. (unsurveyed) .. & & 4. & 7.1 & 7.7 & 6.7 & 8.6 & 15.8 & 20.2 & 17.2 & 17.8 & 100.0 \\
\hline 80 & Center of E. $1 / 2$ sec. 3, T. 29 S., R. $61 / 2 \mathrm{E}$. (unsurveyed) .- & 18.8 & 7.1 & 5.7 & 6.0 & 5.7 & 6.9 & 11.4 & 13. 2 & 7.5 & 17.7 & 100.0 \\
\hline 123 & SE1/4NE1/4 Sec. 23, T. 33 S., R. 1 E. & 3.4 & 1.4 & .9 & 1.4 & 2.0 & 3.4 & 6.5 & 12.6 & 13.0 & 55.4 & 100.0 \\
\hline
\end{tabular}


Mechanical analyses of younger pumice of Crater Lake

\begin{tabular}{|c|c|c|c|c|c|c|c|c|c|c|c|}
\hline $\begin{array}{l}\text { No. on } \\
\text { pl. } 16\end{array}$ & Locality & $\begin{array}{l}64-32 \\
\text { milli- } \\
\text { meter }\end{array}$ & $\begin{array}{l}32-16 \\
\text { milli- } \\
\text { meter }\end{array}$ & $\begin{array}{c}16-8 \\
\text { milli- } \\
\text { meter }\end{array}$ & $\begin{array}{l}\text { 8-4 } \\
\text { milli- } \\
\text { meter }\end{array}$ & $\begin{array}{l}4-2 \\
\text { milli- } \\
\text { meter }\end{array}$ & $\begin{array}{l}2-1 \\
\text { milli- } \\
\text { meter }\end{array}$ & $\begin{array}{l}1-0.5 \\
\text { milli- } \\
\text { meter }\end{array}$ & $\begin{array}{l}0.5-0.25 \\
\text { milli- } \\
\text { meter }\end{array}$ & $\underset{\substack{0.25-0.125 \\
\text { milli- } \\
\text { meter }}}{\mid}$ & Total \\
\hline 1 & West center of SE1 $1 / 4 \mathrm{sec} .8$, T. 27 S., R. $8 \mathrm{E}$ & & 6.1 & 19.7 & 28.5 & 21.0 & & & 3.0 & 0.8 & 100.0 \\
\hline 2 & 200 feet northwest of 1 . & & .9 & 8.8 & 19.1 & 22.6 & 18.7 & 21.8 & 7.4 & $\begin{array}{r}0.8 \\
.6\end{array}$ & 100.0 \\
\hline 3 & Northeast corner of SW 34 NW 14 sec. 6, T. 27 S., & 2.6 & 4. 4 & 17.0 & 23.8 & 20.2 & 13.1 & 13.4 & 4.8 & .7 & 100.0 \\
\hline 4 & East center of sec. 24, T. 26 S., R. 7 E. & & 1.4 & 12.2 & 21.4 & 22.3 & 19.0 & 17.7 & 5.2 & 8 & 100.0 \\
\hline 5 & South center of NE $1 / 4 \mathrm{sec} .36$, T. 25 S., R. 7 E. & & 1.6 & 7.5 & 18.5 & 32.7 & 24.0 & 10.7 & 3.7 & 1.2 & 100.0 \\
\hline 6 & South center of SW1/4SW1 $1 / 4$ sec. 14, T. $26 \mathrm{~S}$., R. $7 \mathrm{E}$. & 3.3 & 9.7 & 14.4 & 16.2 & 14.5 & 12.5 & 18. 7 & 9.1 & 1.6 & 100.0 \\
\hline 7 & $\begin{array}{l}\text { Northeast corner of NE } 1 / 4 \mathrm{SE} 1 / 4 \text { sec. } 24, \text { T. } 26 \mathrm{~S} \text {., R. } 61 / 2 \text { E. (un- } \\
\text { surveyed) }\end{array}$ & & 9.2 & & & & & & & & \\
\hline 8 & $\begin{array}{l}\text { surveyed) } \\
\text { NE1/4E1/4 sec. } 16, \text { T. } 25 \text { S., R. } 7 \mathrm{E}\end{array}$ & & $\begin{array}{l}9.2 \\
4.7\end{array}$ & $\begin{array}{r}17.2 \\
7.3\end{array}$ & $\begin{array}{l}20.6 \\
22.1\end{array}$ & $\begin{array}{l}16.3 \\
23.6\end{array}$ & $\begin{array}{l}13.5 \\
18.3\end{array}$ & $\begin{array}{l}15.8 \\
18.3\end{array}$ & $\begin{array}{l}6.0 \\
5.2\end{array}$ & $\begin{array}{r}1.4 \\
.5\end{array}$ & $\begin{array}{l}100.0 \\
100.0\end{array}$ \\
\hline $\begin{array}{l}8 \\
9\end{array}$ & Center of NW $1 / 4 \mathrm{SE} 1 / 4$ sec. 36 , T. 24 S., R. 6 E. & & .5 & 13.5 & 23.0 & 21.4 & 16.9 & 18.3 & 5.0 & 1.4 & $\begin{array}{l}100.0 \\
100.0\end{array}$ \\
\hline 10 & South center of NE1/4SW1 $1 / 4$ sec. 12 , T. 24 S., R. 6 & & .2 & 1.2 & 10.7 & 21.7 & 24.8 & 31.3 & 9.6 . & .5 & 100.0 \\
\hline 11 & North center of NW $1 / 4$ sec. 34, T. 24 S., R. 9 E. & & & 3.0 & 13.2 & 21. 0 & 22.4 & 25.0 & 14.4 & 1.0 & 100.0 \\
\hline 12 & NW $1 / 4$ SW1/4 sec. 9 , T. 24 S., R. 9 E.; lower part of pumice sheet. & & & & .1 & 3.4 & 19.9 & 36.8 & 38.1 & 1.7 & 100.0 \\
\hline 13 & Same as 12 but upper part of pumice sheet & & .6 & 2.0 & 8.8 & 13. 9 & 20.2 & 29.5 & 23.0 & 2.0 & 100.0 \\
\hline 20 & West center of SE1/4 sec. 19, T. 27 S., R. 7 E. & & 9.5 & 17.8 & 20.7 & 16.6 & 11.5 & 16.6 & 6.1 & 1.2 & 100.0 \\
\hline 21 & NW1/4NW1/4 sec. 29, T. 27 S., R. 8 E.......... & & 10.3 & 26.5 & 25.5 & 13.4 & 7.9 & 11.2 & 4.0 & 1.2 & 100.0 \\
\hline 27 & Southeast corner of NW $1 / 4$ NW1 $1 / 4$ sec. $32, \mathrm{~T} .27 \mathrm{~S} ., \mathrm{R} .6 \mathrm{~F}$ & & 14.2 & 31.9 & 23.0 & 17.6 & 9.1 & 2.1 & 1.3 & .8 & 100.0 \\
\hline 28 & Center of SW $1 / 4$ sec. 1, T. 26 S., R. 6 E. (unsurveyed).. & 2.5 & 6.9 & 19.5 & 24.2 & 18.8 & 12.6 & 12.3 & 2.5 & .7 & 100.0 \\
\hline 29 & Northeast corner of sec. 1, T. $26 \mathrm{~S}$., R. $6 \mathrm{E}$. (unsurveyed) & & 8. 3 & 9. 9 . & 21.0 & 23.9 & 17.3 & 17. 1 & 1.9 & .6 & 100.0 \\
\hline 30 & NW1 $1 / 4$ NE $1 / 4$ sec. 14, T. 25 S., R. 6 E....... & & 11.6 & 16.5 & 22.9 & 19. 9 & 13.5 & 11.0 & 3.4 & 1.2 & 100.0 \\
\hline 40 & Center of $\mathrm{SEL} / 4$ sec. $14, \mathrm{~T} .32 \mathrm{~S}$, R. $71 / 2 \mathrm{E}$. & & 4. 4 & 15.5 & 32.4 & 27.5 & 13.5 & 4.9 & 1.0 & .8 & 100.0 \\
\hline 50 & NW1 $1 / 4$ NW1/4 sec. 27 , T. 26 S., R. 8 E & & 2.3 & 8.5 & 19.1 & 21.0 & 18. 2 & 20.5 & 9.5 & .9 & 100.0 \\
\hline 52 . & Northeast corner of $\mathrm{NE} 1 / 4 \mathrm{sec} .17$, T. $27 \mathrm{~S} ., \mathrm{R} .8 \mathrm{E}$ & & 1.0 & 10.7 & 23.7 & 27.7 & 20.4 & 12.9 & 2.8 & .8 & 100.0 \\
\hline 57 & 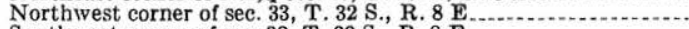 & & 1.1 & 4.5 & 17.3 & 24.3 & 27.1 & 18. 2 & 5.0 & 2.5 & 100.0 \\
\hline 58 & Southw est corner of sec. 32 , T. 32 S., R. 8 E. & & 6.1 & 18.7 & 29.6 & 26.0 & 13.4 & 4.8 & .9 & .5 & 100.0 \\
\hline 59 & Cent ${ }^{\circ} \mathrm{r}$ of $\mathrm{N} 1 / 2$ sec. 15 , T. 31 S., R. 9 E.; upper part of sheet & & 1.7 & 50.7 & 32.6 & 12.0 & 1.5 & .5 & .5 & .5 & 100.0 \\
\hline 60 & Same as 59 but lower part of sheet................ & & 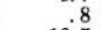 & 7.5 & 21.4 & 32.3 & 24.0 & 6.5 & 3.6 & 3. 9 & 100.0 \\
\hline 69 & Southwest corner of NE1/4SE1 14 sec. $34, \mathrm{~T} .28 \mathrm{~S} ., \mathrm{R} .9 \mathrm{E} .$. & 7.9 & 16.7 & 24.7 & 22. 2 & 15.1 & 6.2 & 4.9 & 1.7 & .6 & 100.0 \\
\hline 70 & Center of NW1/4 sec. 32 , T. $28 \mathrm{~S}$, , R. $10 \mathrm{E}$ & & 11.3 & 38.7 & 22.6 & 11.0 & 4. 5 & 3.7 & 4. 5 & 3.7 & 100.0 \\
\hline 71 & $\mathrm{NE} 1 / 4 \mathrm{SE} / 4 \mathrm{sec} .27, \mathrm{~T}, 28 \mathrm{~S} ., \mathrm{R} .10 \mathrm{E}$ & 9.1 & 28.5 & 30.9 & 16.6 & 7.3 & 2.7 & 2.9 & 1.3 & .7 & 100.0 \\
\hline 72 & North center of $\mathrm{SE} 1 / 4 \mathrm{sec} .27, \mathrm{~T} .28 \mathrm{~S} ., \mathrm{R} .10 \mathrm{E}$ & & .3 & 1.8 & 10.6 & 23.4 & 21.1 & 32.6 & 9.7 & .5 & 100.0 \\
\hline 73 & corner of NW $1 / 4 \mathrm{SE} 1 / 4 \mathrm{sec} .7$, T. $30 \mathrm{~S} ., \mathrm{R} .10 \mathrm{E}$. & & 4. 9 & 17.2 & 30.4 & 28.0 & 12.3 & 3.3 & 2,1 & 1.5 & 100.0 \\
\hline 74 & $\mathrm{SE} 1 / 4$ sec. 25 , T. 29 S., R. 9 E & ..... & 18.6 & 29.3 & 25.4 & 11.8 & 5.6 & 5.3 & 2.0 & 2.0 & 100.0 \\
\hline 81 & East center of SW1 $1 / 4$ sec. 18, T. 25 S., R. $10 \mathrm{E}$ & ..... & 2.0 & 14.2 & 20.1 & 19.8 & 16,2 & 17. 0 & 9.8 & .9 & 100.0 \\
\hline 82 & Center of NE $1 / 4 \mathrm{SE} 1 / 4 \mathrm{sec} .25$, T. $25 \mathrm{~S} .$, R. 9 E & .... & 11.7 & 20.0 & 24.3 & 19.3 & 12,7 & 8. 0 & 3.7 & .3 & 100.0 \\
\hline 83 & Center of sec. 7, T. 26 S., R. 10 E.. & & 4.7 & 15.4 & 20.5 & 20.6 & 16. 3 & 15. 1 & 6.7 & .7 & 100.0 \\
\hline 84 & Center of $\mathrm{W} 1 / 2 \mathrm{NE} 1 / 4$ sec. $14, \mathrm{~T} .26 \mathrm{~S}$., R. $10 \mathrm{E}$. & .... & & 2.6 & 7.9 & 13. 3 & 20.7 & 26,8 & 24,3 & 4,4 & 100.0 \\
\hline & Center of SE1 $1 / 4 \mathrm{SE} 1 / 4$ sec. 14, T. $26 \mathrm{~S} ., \mathrm{R} .10 \mathrm{E} \ldots$ & & 12.6 & 15.8 & 18. 1 & 16. 5 & 14.7 & 16.5 & 5. 3 & .5 & 100.0 \\
\hline 86 & Center of sec. 5, T. 27 S., R. $10 \mathrm{E}$ & 5.9 & 9.8 & 22.3 & 21.2 & 16. 7 & 10. 9 & 9.8 & 3.1 & .3 & 100.0 \\
\hline 87 & Southeast corner of sec. 18, T. 27 S., R. $9 \mathrm{E}$. & 3.6 & 8. 7 & 23. 2 & 25.2 & 15.5 & 15.9 & 5. 9 & 1.6 & .4 & 100.0 \\
\hline $\begin{array}{l}88 \\
89\end{array}$ & 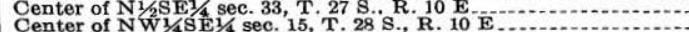 & & $\begin{array}{r}10.0 \\
2.4\end{array}$ & $\begin{array}{l}18.1 \\
19.2\end{array}$ & $\begin{array}{l}23.5 \\
30.0\end{array}$ & $\begin{array}{l}21.4 \\
22.4\end{array}$ & $\begin{array}{l}13.3 \\
12.8\end{array}$ & $\begin{array}{l}11.2 \\
11.3\end{array}$ & $\begin{array}{l}2.3 \\
1.4\end{array}$ & $::_{5}^{2}$ & $\begin{array}{l}100.0 \\
100.0\end{array}$ \\
\hline $\begin{array}{l}89 \\
90 \\
91\end{array}$ & 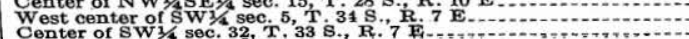 & & & $\begin{array}{r}3.2 \\
5 ; 7\end{array}$ & $\begin{aligned} 3.9 \\
21.3\end{aligned}$ & $\begin{array}{l}18.9 \\
43.4\end{array}$ & $\begin{array}{l}37.0 \\
27,8\end{array}$ & 6,4 & & & $\begin{array}{l}100.0 \\
100.0\end{array}$ \\
\hline
\end{tabular}




\section{NONMETALLIC MINERAL RESOURCES OF EASTERN OREGON}

The results of some of these analyses have been plotted graphically, and in figure 8 typical distribution diagrams of the older pumice of Crater Lake are reproduced. The wide range of particle sizes as fractions of considerable amount indicates poor sorting, but if to these diagrams were added the coarser fractions, which attain 3 feet in diameter, there would appear to be no sorting whatever.

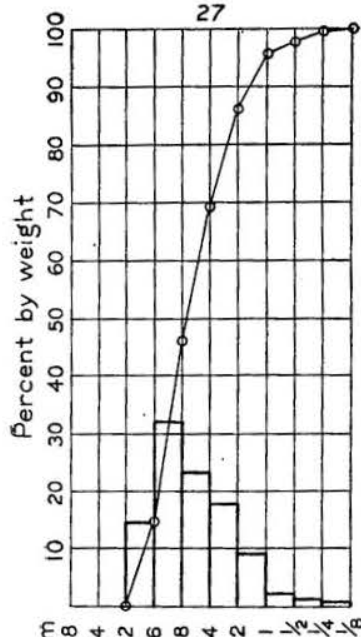

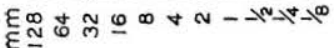

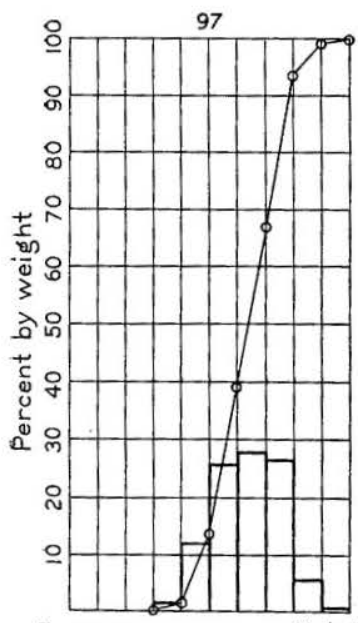

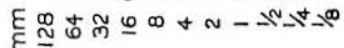

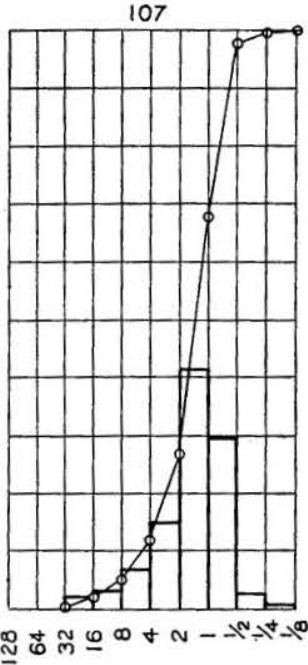

10

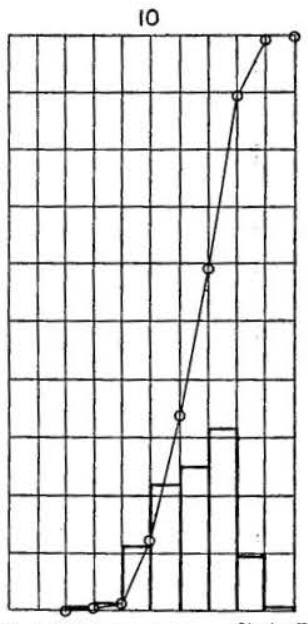

$\stackrel{\sim}{\sim}$ ฮั

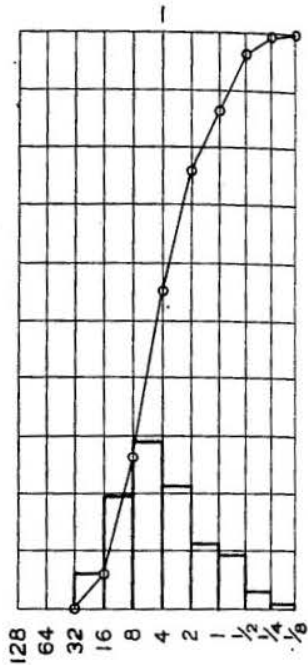

86

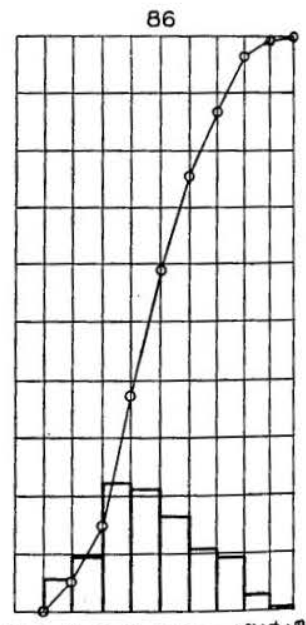

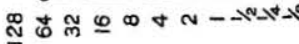

Figurm 9.-Size distribution of younger pumice of Crater Lake.

The younger pumice of Crater Lake is much better sorted, as shown by typical diagrams reproduced in figure 9 . In this pumice there is from 1 to 2 percent of material below 0.125 millimeter in diameter which represents weathered pumice and which is therefore omitted from calculations. Of considerable interest is the fact that the samples consist of two very different types of particles-large 
light pumice granules and fine dense mineral grains. Little pumice finer than 1 millimeter is present in the samples. In general the 1 to 2 millimeter fraction may be considered to be from a half to twothirds pumice. The finer grades contain less pumice still, and so the diagrams really represent two sortings-one of pumice and the other of accompanying mineral grains - each of which is well sorted. When both are combined they give a rather great range in size. It is interesting to note that the fine sandy portion is evenly distributed throughout the material. There is no evidence of segregation of the heavy mineral grains, such as would be expected had the pumice been reworked by winds as it lay on the surface. To confirm the apparent uniformity of distribution of the mineral grains a section was measured in a pumice pit near Chemult and samples 150 to 156 were collected from the pit at different levels. These samples (see table) show no segregation of the mineral grains and indicate that they were deposited with the pumice particles.

The older pumice of Crater Lake is marked by (1) unsorted nature of material, (2) lack of relation between particle size and distance from source, (3) material derived from one magma, no noticeable foreign material except vegetable matter being incorporated, (4) presence of charred vegetation in Rogue River area of the deposit, (5) extent very large, greater than avalanches could produce, (6) restriction of material to area smaller than would correspond to particle sizes in normal eruption, (7) presence of material on ridges.

The unsorted nature of the material and the lack of relation between particle size and distance from source eliminate the possibility of its being produced by the common type of eruption. The great extent of the deposit precludes its origin from volcanic avalanches, which travel only down the steeper slopes of a volcano. The temperature, as indicated by the abundant charred logs in the Rogue River region, was much greater than could be expected from any mud flow containing water as a diluent. The presence of the material on ridges also indicates another means of deposition than mud flows. The presence of the pumice on the steep upper slopes of the crater, the uniformity of the material, the presence of so much fine material near the source, and the absence of material that might have been reworked remove the possibility of origin in reworking of older deposits by torrential cloudbursts.

The pumice resembles, however, deposits left in eruptions similar to that of Mount Pelee, in Martinique, in 1902. This type of eruption and the products have been described by Lacroix, ${ }^{78}$ Anderson

\footnotetext{
${ }^{78}$ Lacroix, A., La Montagne Pélée et ses éruptions, Paris, 1904; Remarques sur les watériaux de projection des volcans et sur la génèse des roches pyroclastiques qu'ils constituent: Soc. gêl. France, Jubilee volume, vol. 2, pp. 431-472, 1930.
} 
and Flett, ${ }^{79}$ Völzing, ${ }^{80}$ and Fenner. ${ }^{81}$ In a separate paper ${ }^{82}$ the Crater Lake material is discussed in more detail.

The younger pumice of Crater Lake is of the ordinary eruptive type and is believed to have followed closely the numerous Peleean eruptions that deposited the older pumice.

\section{PUMICE OF NEWBERRY CRATER}

A sheet of granular pumice occupying an area of some 200 square miles extends nearly 25 miles east from the Paulina Lakes of Newberry Crater. Though this sheet is not as large as that of Crater Lake, the quality of the pumice is sufficiently high to merit attention.

The history of Newberry Crater, as summarized by Russell, ${ }^{83}$ begins with the building of a lofty volcanic cone. It is probable, however, that the present basin owes its origin more to volcanic processes than to the erosional processes which Russell mentions. Williams ${ }^{84}$ believes that the enlargement of the originally small crater to its present size and shape was due largely to collapse and faulting rather than to erosion. After the breaching of the west side of the crater glaciation modified the inside as well as the outside of it, and on the retreat of the glacier the morainal material mentioned by Russell as occurring at the outlet of Paulina Lake was deposited. After the glacial epoch had passed a series of small cones was built on the crater floor, as shown in figure 10. The northernmost one of these cones was formed first, according to Russell, and the next two in age are the central and the southwestern ones. These cones are formed of a yellow tuff and agglomerate, and some lava is associated with the northernmost one. After these cones had been built rhyolite was erupted on the south slope of the inner crater wall. During the first stages of this eruption huge quantities of pumice were thrown out and formed the present pumice sheet. The pumice was followed by a great stream of viscous glass, which advanced nearly to the present lake basins. During this eruption or shortly after it the small pumice cone on the southwestern shore of East Lake was formed. This cone is composed of material very similar to that of the main pumice sheet.

\footnotetext{
${ }^{7}$ Anderson, T., and Flett, J. S., Report on the éruptions of the Soufriere in St. Vincent in 1902 and on a visit to Montagne Pelee in Martinique, pt. 1: Roy. Soc. London Philos. Trans., ser. A, vol. 200, pp. 353-555, 1903.

${ }^{80}$ Völzing, K., Der Trass des Brohltales: K. preuss. Geol. Landesanstalt Jahrb., vol. 28, pp. 1-56, 1907.

${ }^{81}$ Fenner, C. N., The origin and mode of emplacement of the great tuff deposit of the Valley of Ten Thousand Smokes: Nat. Geog. Soc. Contr. Tech. Papers, Katmai series, no. $1,1923$.

Moore, B. N., Deposits of possible nuée ardente origin in the Crater Lake region, Oregon: Jour. Geology, vol. 42, pp. 358-375, 1934.

${ }^{83}$ Russell, I. C., Preliminary report on the geology and ground-water resources of central Oregon: U. S. Geol. Survey Water-Supply Paper 252, p. 105, 1905.

${ }^{84}$ Williams, H. W., Newberry Volcano of central Oregon: Geol. Soc. America Bull., vol. 46, pp. 253-304, 1935.
} 
The pumice of Newberry Crater occupies the area roughly sketched on plate 16. In this region there are small areas from which the pumice has been stripped away by erosion, and also places in which it has been covered by still more recent volcanic rocks. The inner and outer slopes of Newberry crater are well covered by the deposit, which is about 5 feet thick except in areas where it has drifted. About 7 miles to the east it is from 2 to 3 feet thick, and in the

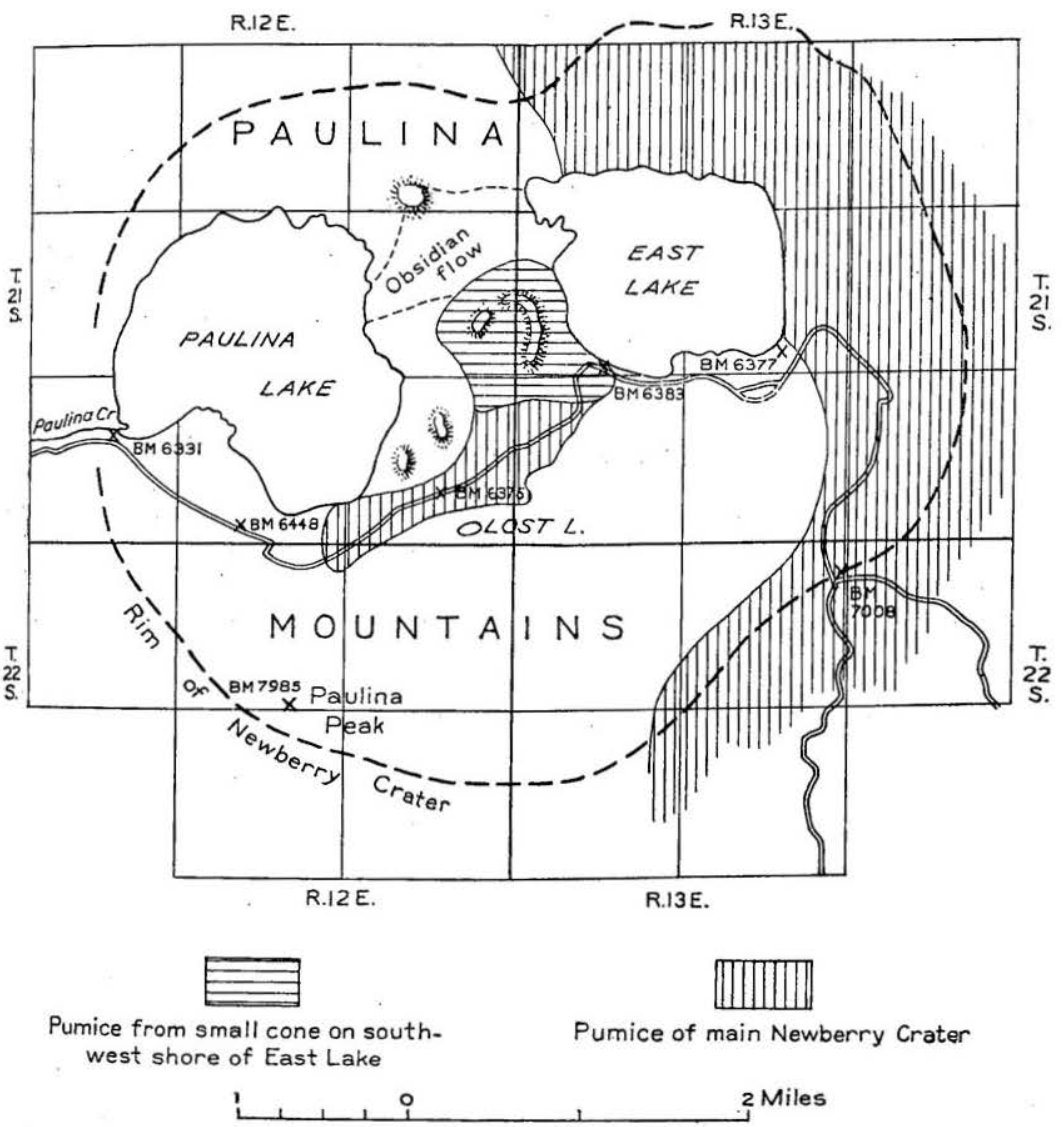

FTGORE 10.- Sketch of Newberry Crater showing approximate location of cones and distribution of pumice.

easternmost localities only 1 foot. The elliptical shape of the field is believed to mark closely the original limits of deposition and is probably due to the effect of directional forces exerted by the eruption.

The pumice of this sheet is very light gray and finely vesicular, with no phenocrysts or stony blebs. Associated with the angular fragments of the pumice are a few very fine-grained fragments of rhyolite and still fewer fragments of obsidian or volcanic glass. 
The size of the particles varies considerably. In the little areas between the edge of the obsidian flow and the lakes the blocks of pumice range in size from about 4 to 10 inches, but on the crater rim the average size of the material is about 1 to 2 inches, and in the easternmost part of the field about $1 / 2$ to 1 inch. In general the material is well sorted, with but little dust or other fines.

The pumice collected from the small pumice cone on the southwest shore of East Lake is a very finely vesicular material with few large vesicles and very pure. It occurs in layers sloping at the angle of repose toward the lake and associated with layers of finer material and dust. These layers are from 1 to $1 \frac{1}{2}$ feet thick and alternate with considerable regularity. The finer layers are mainly dust composed of small striated fragments of glass; the coarser layers contain lumps as much as 6 inches in diameter. There is no foreign material in these layers. A chemical analysis of sample 116 made in the laboratory of the Geological Survey gave the following result:

Analysis of pumice from sec. 30,T.21 S., R. $18 \mathrm{E}$.

[J. J. Fahey, analyst]

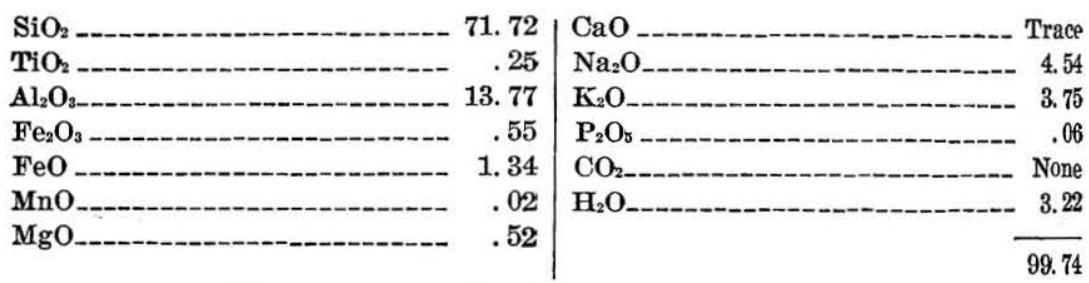

The composition corresponds closely to that of a rhyolite.

Mechanical analyses have been made of the various samples with the results shown in the following table: 
Mechanical analyses of pumice of Newberry Crater

\begin{tabular}{|c|c|c|c|c|c|c|c|c|c|c|c|c|}
\hline $\begin{array}{l}\text { No. on } \\
\text { pl. } 16\end{array}$ & Locality & $\begin{array}{l}64-32 \\
\text { milli- } \\
\text { meter }\end{array}$ & $\begin{array}{l}\text { 32-16 } \\
\text { milli- } \\
\text { meter }\end{array}$ & $\begin{array}{c}\text { 16-8 } \\
\text { milli- } \\
\text { meter }\end{array}$ & 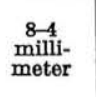 & $\begin{array}{c}\text { 4-2 } \\
\text { milli- } \\
\text { meter }\end{array}$ & $\begin{array}{c}2-1 \\
\text { milli- } \\
\text { meter }\end{array}$ & $\begin{array}{l}1-0.5 \\
\text { milit- } \\
\text { meter }\end{array}$ & $\begin{array}{c}0.5-0.25 \\
\text { milli- } \\
\text { meter }\end{array}$ & $\underset{\substack{0.25-0.125 \\
\text { milli- } \\
\text { meter }}}{\mid}$ & $\begin{array}{l}\text { Less than } \\
0.125 \\
\text { milli- } \\
\text { meter }\end{array}$ & Total \\
\hline 17 & $\mathrm{SE} 1 / 4 \mathrm{SE} 1 / 4$ sec. 4, T. $22 \mathrm{~S} .$, R. $13 \mathrm{E}$. & & 18.6 & 35.7 & 31.9 & 11.6 & 1.8 & 0.4 & & & & 100.0 \\
\hline 18 & Northeast corner of sec. 15 , T. 22 S., R. 14 E. & & 34.2 & 36.9 & 23.2 & 4.6 & .8 & .3 & & & & 100.0 \\
\hline 19 & NE1/4SE1/4 sec. 24, T. $21 \mathrm{~S}$, R. $15 \mathrm{E}$ & & 3.5 & 23. 1 & 37.0 & 25.5 & 8.8 & 1.2 & 0.6 & 0.3 & & 100.0 \\
\hline 109 & NE1 $1 / 4 N E 1 / 4$ sec. 31 , T. 21 S., R. 13 E & & .1 & 2.5 & 7.2 & 7.4 & 7.2 & 10.9 & 6.3 & 8.7 & 49.7 & 100.0 \\
\hline 113 & $\begin{array}{l}\text { Pumiceous gravel from beach at } 109 \\
\text { Center of NE1/4SW1/4 sec. } 30, T \text {. } 21 \mathrm{~S} . \mathrm{R} .13 \mathrm{E} \text {; granular }\end{array}$ & & & 50. & 35.7 & 7. & .8 & & & & & \\
\hline & material finer than material at 111.... & 2.4 & 14.3 & 10.6 & 9. & 7. & 6.2 & 6.3 & 4. 7 & 6.9 & 31.3 & 100.0 \\
\hline 114 & Northwest corner of SE $1 / 4$ sec. 35 , T. 21 S., R. 13 E. & & 2 & 2.2 & 6.1 & 10.9 & 8.2 & 6.7 & 6.2 & 10.1 & 49.4 & 100 \\
\hline 115 & Northeast corner of SW1/4 sec. 10, T. $21 \mathrm{~S} .$, R. $13 \mathrm{E}$. & & 2.8 & 17.5 & 29.5 & 25.4 & 16.9 & 6.3 & 1.4 & .2 & & 100.0 \\
\hline 116 & Southeast corner of NW1/4 sec. 23, T. 21 S., R. 14 E & 3.3 & 2.0 & 3. 1 & 4. & 4.9 & 8.1 & 18.4 & 27.6 & 10.5 & 17.4 & 100.0 \\
\hline 117 & Northeast corner of SE $1 / 4 \mathrm{SE} 1 / 4 \mathrm{sec} .24, \mathrm{~T} .21 \mathrm{~S} .$, R. $14 \mathrm{E}$. & & 10.1 & 26.4 & 29. & 19.4 & 10.0 & 3.0 & 1.4 & .5 & & 100.0 \\
\hline 118 & Northeast corner of sec. 17 , T. 22 S., R. 13 E...... & 8.0 & 16.4 & 20.7 & 23.9 & 17.2 & 9.0 & 3.4 & 0 & .6 & & 100.0 \\
\hline
\end{tabular}


The sorting of the pumice in the larger sheet is excellent, as shown in figure 11, and points to an ordinary eruptive origin. The pumice of the cone on the lake shore is much less well sorted, probably owing to the short distance to which the ejecta were thrown and the consequent mingling of different fractions and also to the alternation of different types of eruptive activity, which produced first fine and then coarse material.
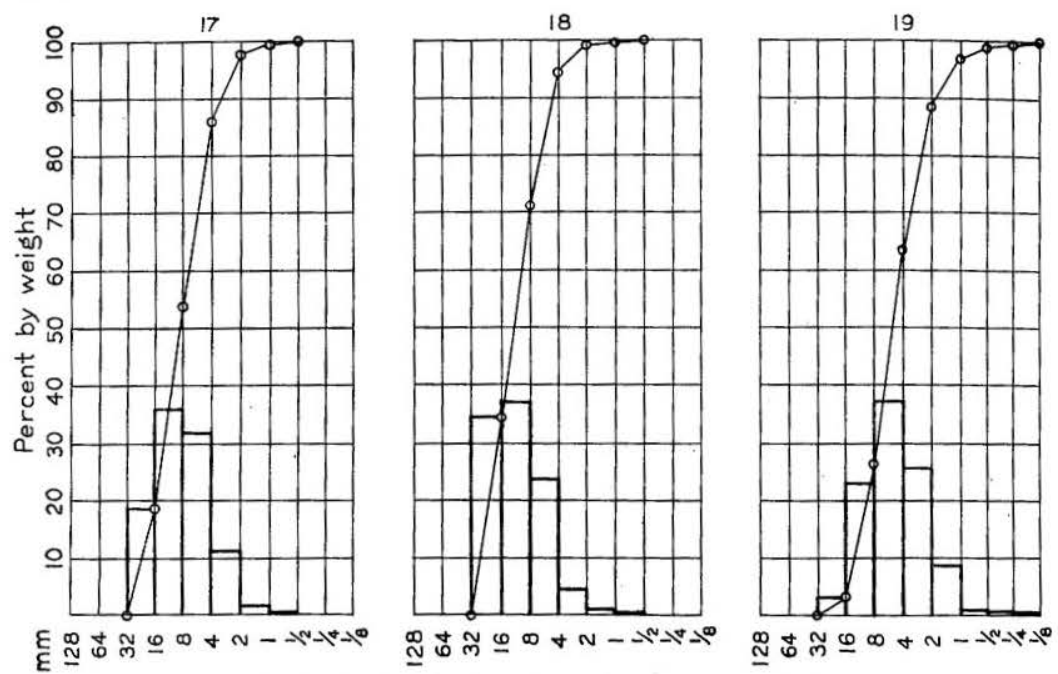

Frgure 11.-Size distribution of pumice from Newberry Crater.

PUMICE OF DEVILS HILL

A small sheet of pumice occurs in the vicinity of Elk Lake, in the northern part of the region investigated. This sheet is now almost completely removed by erosion, but small amounts of pumice may be found on the beaches of Elk and Lava Lakes and in protected spots. This sheet probably had its origin in the eruption of Devils Hill. After the initial eruption of pumice a large amount of a porphyritic glass was poured out, which built up the present mass of Devils Hill and the great ridge that extends from Devils Hill to Kaleetan Butte.

The pumice of this sheet varies greatly in quality. It is a lightgray finely vesicular rock with no phenocrysts, glassy blebs, or large vesicles and occurs in lumps from 1 to 2 inches in diameter associated with large amounts of more stony pumice and also with fragmental obsidian and rhyolite. The quality of this pumice is too poor to arouse commercial interest. The occurrence is interesting, however, because it represents a phase of volcanic activity similar to that of Newberry Crater. Here the more basic eruptions of the Three Sisters were followed by the acidic vitrophyres of Devils Hill before the beginning of the later basaltic series. 
Although the pumice in this region is of Pleistocene age, there is a well-developed sequence of later rocks aside from the alluvium. Small areas of sediments occur, among which may be mentioned the deposit of diatomite in the Davis Lake Basin. However, these sediments occupy much smaller areas than the recent basalts. No mapping of the geology of this region has been attempted, but in the Forest Service timber cruises on national-forest land the lava flows of this age have all been noted as waste spaces. These flows occupy areas of considerable size in the northerin part of the region. Among the more notable of them is the flow of Lava Butte, about 15 miles south of Bend, which occupies nearly 10 square miles. Other flows occur on the north slope of the Paulina Mountains. On the south slope of the Paulina Mountains there are a number of basaltic cinder cones and flows which definitely overlie the pumice of both Crater Lake and the Newberry Crater.

Where these rocks overlie the older pumice sheets, the pumice is so thin or so poor that it is of no commercial value.

\section{ECONOMIC ASPECTS OF THE PUMICE}

Lump pumice of possible commercial interest covers an area of about 3,500 square miles east of the summit of the Cascade Range. There are three different types, which are represented by the older and younger pumice sheets of Crater Lake and the pumice of Newberry Crater.

The quantity of the older pumice of Crater Lake is relatively huge, but no definite maximum estimate can be given, because no detailed measurements were made. On the summit of the Cascade Range near Diamond Lake there are thicknesses greater than 100 feet, and along the Rogue River in western Oregon as much as 60 feet. Along the Dalles-California Highway the thickness ranges from 3 to more than 10 feet. A minimum estimate of the quantity present can be safely based on a thickness of 3 feet distributed over an area of 350 square miles. This gives a total of about $1,000,000,000$ cubic yards.

This deposit is relatively accessible. In its eastern portion it is crossed by the Dalles-California Highway, the Southern Pacific Railroad, and the Great Northern Railway. Along the railroads much of the land is level, is covered by an open forest, and has but a few inches of soil cover. Though in places the removal of vegetation might be expensive, the forest timber is valuable in itself, and after its removal the deposit would be ideally open for steam-shovel quarrying. The large percentage of coarse lump material should 
make mining fairly cheap, for after passage through trommels and after a preliminary sorting the lumps would be ready for shipment.

The possible uses of this pumice are varied. The deposits along the Rogue River are now being used in the Oregon Portland Cement Co.'s plant at Gold Hill as an admixture to improve not only the workability of concrete but also its strength and resistance to corrosion. Quantities of the lump material have been collected on the flats along the railroads, sacked, and sold at high prices in Chicago, but for what use is unknown. The size of the lumps, of which more than half are above 10 inches in diameter, suggests that they might be cut into abrasive blocks for use where first-quality pumice is not necessary. The two bad qualities of the lump pumice are the presence of crystals of feldspar, augite, and hypersthene and the presence of considerable percentages of large vesicles, which give a rather uneven texture to the lumps. The fines might well be used for abrasive powders, as they contain but little material other than the glass grains, which are finely striated.

Younger prumice of Crater Lake.-The younger pumice of Crater Lake is a clean granular material made up of granules of pumice and sand grains composed of feldspar, augite, and hypersthene crystals. A fairly sharp separation of these two parts can be made by sifting with a sieve of about $\frac{1}{16}$-inch mesh. Mechanical analyses of the samples collected are given on pages 162-163. There is a gradual decrease in amount of coarse material present from the center to the edge of the deposit, so that different parts of the deposit might well be used for the production of different-sized granular pumice. Very little foreign material occurs in this pumice, but it contains a few small fragments of basalt and andesite.

This pumice forms a single sheet which covers about 3,000 square miles east of the Cascade Range. The original thickness was probably much greater than that now present, which ranges from about 6 feet near the center of the deposit to about 1 foot at the boundary shown on the map. There is a variation of fine to coarse from the bottom of the deposit to the top, though the relative amounts of sand to pumice do not change. The deposit is free of fines with the exception of those formed by a slight amount of weathering.

The quantity of pumice present in this deposit is large. More than 90 percent of the area occupied by this pumice as mapped is covered with a blanket of this material, which effectively hides the older rocks. In the vicinity of Crescent this blanket is about 6 feet thick. Where the material has drifted from steep hill slopes or has been carried by streams its thickness is still greater. A conservative estimate of the amount of this pumice present, based upon a thickness of 3 feet distributed over half the total area of 3,000 square miles, amounts to $45,000,000,000$ cubic yards. 
Large quantities of this pumice are easily accessible. The thickest and best parts lie along the Dalles-California Highway and the two railroad lines. It is everywhere covered to a thickness of as much as 1 foot with soil made of weathered pumice and ordinarily supports an open pine forest. Removal of this forest cover would make the deposit easily accessible to steam-shovel operation, and mining need only include the digging and passing of the material through a trommel or other type of screen to produce commercial granular pumice.

This pumice is adaptable to a number of uses, particularly those in which granular material is desirable, such as light-weight concrete aggregate, acoustic or sound-proofing plasters, and insulating material. It might also be used as packing in absorption towers, as a carrier for catalysts, and as a carrier for ferments in making vinegar. The small amount of phenocrysts it contains prevents its use as a high-quality abrasive, but where these are not injurious it might be used in tumbling barrels and perhaps be ground for use as powder.

Pumice of Newberry Crater.-Pumice of very high quality occurs in the Newberry Crater field. The granular pumice of the large area shown on the map is a very light gray, finely vesicular material with no phenocrysts or glassy blebs. The coarseness of the material varies with the distance from the point of origin. In the crater material as much as 1 foot in diameter is common, whereas on the east slope the size ranges largely between 1 and 2 inches, and in the extreme eastern part of the field it is under $1 \mathrm{inch}$. Associated with the pumice is a certain amount of fragmental obsidian and lava-usually less than 5 percent. The material of finest quality, however, is that which occurs along the southwest shore of East Lake and forms the small pumice cone there. This material is mixed with fine dust, the lump material occurring in thin layers. It is of a silvery-gray color, is finely vesicular, with very few large vesicles, and appears to be free of admixture with obsidian or rhyolite. It is marked likewise by a complete absence of phenocrysts.

The amount of pumice present in this deposit is much smaller than that of the other deposits but is still large. If the area covered by the pumice sheet is reckoned at 150 square miles and the average thickness of the deposit over this area is taken as 2 feet, a total of $300,000,000$ cubic yards is obtained. If the amount of lump pumice and ash present in the small pumice cone is reckoned as a cone 1,000 feet in diameter at the base and 200 feet high a figure of more than 1,500,000 cubic yards is obtained of which perhaps a quarter, or about 375,000 cubic yards, is lump pumice. 
This pumice sheet is accessible to the Great Northern Railway by hauls of 12 to 40 miles over narrow mountain roads. A standardgage lumber railroad now runs through the eastern part of the deposit which could probably afford rail transportation to the Great Northern Railway at Bend. The relatively high quality of the pumice from this deposit perhaps offsets its inaccessibility.

Although the applications of this material are for the technologist to decide, the pumice appears to be adaptable to any of the uses for which lump pumice is fitted. Lumps over 4 inches in diameter are not abundant, but lumps of 2 to 4 inches are common. The uniformly fine vesicularity of the pumice and the absence of any stony or glassy blebs fit this material for use as a high-quality abrasive. When powdered it forms small glass grains of aniform size with flattish striated sides-fragments of the small glass filaments, which give some specimens of the lump material a silky sheen.

\section{DEVELOPMENT}

The pumice deposits of eastern Oregon are practically undeveloped, probably because of the very recent availability of suitable railroad transportation.

Older pumice of Crater Lake.-The Gold Hill plant of the Oregon Portland Cement Co. uses the older pumice of Crater Lake as a cement admixture in its "Special" brand of cement. The deposit that supplies this plant is on the Rogue River in the $\mathrm{SE} 1 / 4 \mathrm{NE} 1 / 4$ sec. 23 , T. 33 S., R. 1 E., and is owned and operated by T. A. CarIton, of Trail, who sells the pumice under contract to the cement company at 10 cents a ton plus his expenses. The pumice here is largely volcanic dust, with small amounts of large lump material and charcoal. A quarry that has been opened in the deposit is completely mechanized and can be operated by one man. The pumice is gathered by a drag-line scraper operated by a tractor and is dumped through a shaft into a dump car which runs into the hillside in a tunnel. The car, when filled, is run out to a bucket elevator that carries the pumice into a storage bin, from which it is discharged into trucks for shipment to the cement mill.

The lump pumice that occurs along the Dalles-California Highway weathers out to boulder-strewn flats. For a number of years Joe Ball, an Indian of the Klamath Reservation, gathered these lumps, sacked them, and shipped them to Chicago at a considerable profit, paying a royalty of about $\$ 1$ a ton to the tribe for material taken from tribal lands and to private landowners for material gathered outside the reservation. The amount shipped annually by Ball is reported by his widow to have varied from 4 to 10 carloads of about 25 tons each over a period of about 5 years. Several 
types of pumice were recognized, of which the deeply weathered pink type was considered most desirable. Only the larger lumps were in demand by the company that bought this material. It is reported that prices ranging from $\$ 25$ to $\$ 35$ a ton were obtained for sacked material f. o. b. Diamond station.

Younger pumice of Crater Lake.-The younger pumice of Crater Lake has been much less developed even than the older. Several quarries have been opened-in the vicinity of Chemult, where the deposit is thickest, and attempts have been made to utilize it.

In sec. 8 , T. 27 S., R. 8 E., the granular pumice is more than 20 feet thick. Plate 12, $B$, shows an exposure of the pumice along the east bank of the Southern Pacific Railroad cut. This pumice is similar to that described on preceding pages. The great thickness here present is probably due to drifting and is local. The California Stucco Products Co., of San Francisco, attempted to develop this material for use in stuccos. It took out a special-use permit from the Forest Service covering about 90 acres in the southwestern part of the section for the years 1929 and 1930 . In 1929 this company sacked and shipped 13 cars of granular pumice which contained 765 cubic yards of material, for which it paid the Forest Service a royalty of 5 cents a cubic yard. No work was done here in 1930 or in 1931. 


\section{INDEX}

$\mathbf{A}$

\section{Abstract.}

Acknowledgments

Agate, occurrence of

Alkali Valley, diatomite deposits in. American Diato Co., development work by -

Anhydrite, occurrence of

deposits of, geology of _-- 11-13, pl. 3 location of -_._-_- 10-11, pl, 1 size of - 17

occurrence of

origin of

production of - 8-10

Atomite Corporation, operations by- 26, pl. 3

Austin area, diatomite deposits in

diatomite from_..._. $46, \mathrm{pl}, 6$ examination

61|

geology of -

\section{B}

Baker County, limestone deposits Beatty, diatomite deposits near, features of _._._-_ 44-45

diatomite deposits near, section of

Bend-Klamath Falls region, development of pumice deposits in

drainage of 152-153

geology of 153-171

post-pumice rocks of, occurrence and age of

pre-pumice lavas of, occurrence and age of ____ 153-155

pumice deposits in $150,155-170$, pl. 16 topography of

151-152

Bentonite, possible occurrence of --- 6

Black Marble \& Lime Co., quarry of - 130-132

Blue Mountains, diatomite deposits in -

Borax, occurrence of... 6

Brogan area, diatomite deposit in, features of

diatomite deposit in, section of- 64 diatomite from_.._ $62, \mathrm{pl} .7$ examination of geology of 64

Building stone, occurrence and character of
Page 33-34 diatomite from-_._. $24, \mathrm{pl} .4$ examination of -...-...- 34 geology of region of - 33 section of formations near._.-_ $\quad 33$

\section{C}

Chemult, deposit of pumice near, thickness of _-_._- 158, pl. 12 pumice from, chemical analysis of - 159 mechanical analysis of -.- 165

Chiloquin, diatomite deposits near, features of - 40

diatomite deposits near, section of _- 40

Clarno formation, age and correla. tion of - 155

relations of - 3-4

Clover Creek district, development in

diatomite deposits in

diatomite from_-_-_-_._- $46, \mathrm{pl} .6$ examination and analysis of - 55

field work in

geology of

mining conditions in

section of diatomite material from

Columbia River lava, age and correlation of

occurrence of _..._._._._- 124-125, 138 relations of

Connor Creek district, Columbia River lava in

general features of

igneous rocks in limestone deposits in, general features of - geology of structure of _-_ 138-139 Crater Lake, age of pre-pumice lava in vicinity of pumice deposits of, development of pumice of chemical analyses of.-.- 157,159 economic aspects of --.-- 171-173

mechanical analyses of...---- 161-166 origin of -

Crook and Grant Counties, limestone deposits in 
D

Dalles formation, age and correlation of relations of

Davis Lake, diatomite deposits at, general features of- $23,25-26$; diatomite deposits at, geology of 23-25 dtatomite from 24, pl: 4

examination of -.-.--_---- 26

Deschutes County, pumice deposits in

Deschutes formation, age and correlation of

character of -

origin of - 29

section of

Devils Hills, pumice deposit of --- 170 Diamond Lake, thickness of pumice near

156

Diatomite, apparent density of --- 113-114 character of chemical composition of -..-- 114-117 color of conclusions regarding quality of _. deposits of, development of _-_- 32-33, $56,92-95,106-107, \mathrm{pl} .3$ distribution of - 21, 102-103, pl. 11 general features of -...- 23-27, $30-52,57-64,69-71, \mathrm{pl} .1$

previous investigation of _-- 21-22 fracture, lamination, and toughness of

112

microscopic examinations of _..- 117 occurrence of $30-31,33-34,54, \mathrm{pl} .8$

production of quality of _._- 54-56, 87-92, 107-118 sections of _._._._. $30,77-86, \mathrm{pl} .9$ texture of thickness of beds of trade names of uses of _..._. 18, 92, 105

Diatomite Products Co., development work by _._._. 106-107

Dike rocks, occurrence of _-_.. 123-124.137 Durkee area, diatomite deposits in -- 58-59 diatomite from_-_._. 46 , pl. 6 examination of geology of

\section{E}

Eagle Creek, limestone deposits on_ 133-134 East Lake, pumice deposit near-- 166, 168 Elk Lake, pumice deposits near-..- 170 Erickson, E. T., analyses by $---30,42,43$, $47,48,55,88,104$

\section{F}

Fahey, J. J., analyses by _-- $157,159,168$ Fairchild, J. G., analyses by -- 120, 129, 131, $132,134,139,140,141,147$, 148.
Faults, character of--- 39-40, 75-76, Page 125-126 Field work_--- 2, 34, 53, 65, 95-96, 121, 150 Folds, character of _._._. 75-76, 101

\section{G}

Garnet, occurrence of Geographic relations of the area Geomorphology, development of --- 127-128 Girty, G. H., fossils identified by -- 146-147 Grant and Crook Counties, limestone deposits in _..._. 145-148 Gypsum, occurrence of-_-_._- 7-8

\section{$\mathbf{H}$}

Harper district, accessibility of _-_- $\quad 66$ diatomite from, analyses of ---- 88-92 general features of 90 , pls. 7,10 quality of reserves of uses of

diatomite deposits in, development of sections showing distribution of - 77-87

field work in geography of geologic history of stratigraphy of structure of Hurricane Creek, limestone deposits on -

\section{I}

Imnaha River, limestone deposits on - 119-120

Indian Creek Valley, diatomite deposits in

diatomite from-_-_-_-_-_- 46, pl. 6 examination of _...... 52

geology of Intrusions, character of _._._._. 101-102 $\mathbf{J}$

John Day formation, age and correlation of

relations of John Day region, formations of _-_- 3-4 John Day Valley, diatomite deposits in 63 diatomite from examination of geology of

\section{K}

Klamath County, pumice deposits in. 158, pl. 16

Klamath Falls, diatomite deposits near _... 41-43

diatomite deposits near, sections of 
Page

Klamath Falls, diatomite from diatomite from, examination and analysis of

Klamath Falls region. See BendKlamath. Falls region; Klamath region.

Klamath Lakes, age of lava flows in vicinity of -

diatomite from_-_........ 24, pl. 4

examination of

Klamath Marsh, thickness of pumice near _........ 156, 158

Klamath region, diatomite district in, accessibility of ...-

diatomite district in, geography of _ _

geology of

diatomite deposits in, conclusions regarding - $-50-51$

general features of _.. $34-51$, pl. 5

stratigraphic section in $---0--0$

structural features of

\section{L}

Lava Lake, pumice deposits near _-- 170 Lime area, geology of _-_.- 142-144, pl. 15 limestone deposit in _..._... 142 Limestone, chemical analyses of _- 129,131 , $132,134,139,140,141,144$ 147, 148.

deposits of, accessibility of --- 118-119 general features of _...- 129-130, 132-149, pl. 1

development of examination and analysis of _.. $\quad 120$ occurrence and"character of _- 118-119,

Ioess, occurrence of

Lohman, Kenneth E., fossils identi-

fied by $42-43, \quad 44, \quad 47, \quad 48, \quad 52, \quad 55$ $58-59, \quad 61, \quad 63, \quad 64, \quad 88-92$, 104-105.

Ionroth, thickness of pumice near- 156-157 Lostine River, limestone deposits on - 129-130

Lugnet, - , analysis by 144

\section{M}

Manning Creek, diatomite deposit on -

Marble, occurrence of $58-59$

Mascall formation, relations of

Mesozoic (?) rocks, asbestos deposits in - 11-12

Minerals, nonmetallic, list of resources of

Miocene lava, character, thickness, and occurrence of _.-- 67-68,

$97-98$

Miocene (?) rocks, occurrence of -- 36-37

Monazite, occurrence of

Mount Mazama, age of lava flows in vicinity of
$\mathbf{N}$

Page

Nelson, limestone deposit at _._._. 141-142 Newberry Crater, pumice deposits

$$
\text { of - }
$$

pumice from, chemical analysis

of - 168 economic aspects of mechanical analysis of --- 169-170

Olene district, diatomite deposits in - 49-50

Olivine, occurrence of

Opal, occurrence of

Oregon Portland Cement Co., property of -

Otis Basin, accessibility of diatomite deposits in, development of-_-_-_ 106-107 general features of _ 102-103, pl. 12 reserves in thickness of diatomite from__._._._. 90 , pl. 10 examination and analysis

$\begin{array}{lr}\text { of } & \\ \text { quality of } & 105 \\ \text { uses of } & 104\end{array}$

geology of_-__._-_._- 97-102, pl. 11 investigations in stratigraphic sequence in -...- 97 structure of topography of

P

Pacific Coast Diatom Corporation,

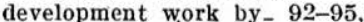

pl. 9

sections on property of -- 80-82, 85-86 Packard, E. L., quoted____._-_ 145-146 Payette formation, age and correlation of

agglomerate and tuff members of _-

character, thickness, and occurrence of --_- 67-71,97-100

diatomite members of _.- 69-71, 97, 99 relations of - 4 rhyolite porphyry member of $\mathbf{7 1 , 9 7 .}$ 99-100 members of _._. 68-71

Peridot, occurrence of Pine Creek district, asbestos deposits in

structure of

Pleistocene lava, occurrence of _-_ $\quad 29$

Pleistocene (?) rocks, occurrence of - 38-39

Pliocene olivine basalt, character, thickness, and occurrence of

Pliocene (?) rocks, diatomite in occurrence of

Poe Valley, diatomite deposits near _- 43-44 diatomite from-_._-_._- 24, pl. 4 examination and analysis of - 
Post-Payette rocks, character, thickness, and occurrence of igneous members of 67, 71-73 sedimentary members of --..-- 72-73

Pumice, age of chemical analyses of $157,159,168$ deposits of, development of _- 174-175 investigation of location of economic aspects of 171-174 mechanical analyses of 161-163, 169-170 occurrence and character of

6 , origin of $155-170$, pl. 16 production of - 150 uses of $149-150$

\section{$\mathbf{Q}$}

Quartz diorite, occurrence of- 124, 137-138 Quaternary deposits, character of - 97, 100, $\begin{array}{rr}143 & 144 \\ \text { occurrence of } & 12\end{array}$

\section{$\mathbf{R}$}

Rattlesnake formation, relations of Recent deposits, occurrence of -..Recent lava, occurrence of Reeside, J. B., Jr., fossils identified by-_._-_._- 120

Richland area, diatomite deposit in - 56-58 geology of

\section{$\mathbf{S}$}

Salines, occurrence of -

Shoofly Creek, limestone deposits

$$
\text { on }
$$

148-149

Sisley Creek, limestone deposit on - 140-141 Slumping, occurrence of _._-_._-_ 73-75

Smith-Emery Co., results of tests by-

Sprague River district, diatomite deposits in...-.-.- 44, 45-48 diatomite deposits in, section of diatomite from of 45 examination and analysis of _. 47,48

Structure, features of -- 12-13, 29, 39-40, 53-54, 73-76, 100-102, 125-127, 138-139, 144

Swayze Creek, diatomite deposit near

.

\section{Vale irrigation canal, diatomite in banks of -} Volcanic rocks, character of

\section{W}

Walker Mountain, age of lava flows of -

Walker Rim, age of lava flows of ---154

Wallowa County, limestone deposits in

Wallowa Mountains, accessibility of 122 Columbia River lava in faults in - $125-126$ geography of geology of geomorphology of igneous rocks in investigation of limestone deposits in limestone deposits in structure of

Triassic sediments in Wheeler County, limestone deposits in _. Whiteurth Products Co., development work by

\section{$\mathbf{Y}$}

Yamsey Mountain, pumice deposit on

Z

Zeolites, occurrence of 6 
The use of the subjoined mailing label to return this report will be official business, and no postage stamps will be required

UNITED STATES
DEPARTMENT OF THE INTERIOR
GEOLOGICAL SURVEY
OFFICIAL BUSINESS
This label can be used only for returning
official publications. The address must not

\section{U. S. GEOLOGICAL SURVEY,}

\section{WASHINGTON, D. C.}

